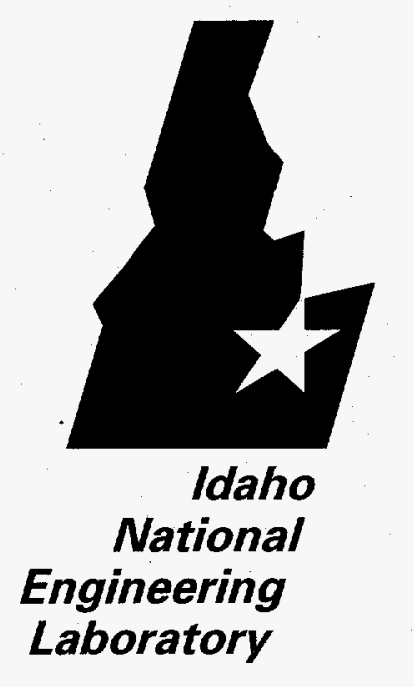

INEL-96/0247

March 1997

\title{
Comparison of Alternative Treatment Systems for DOE Mixed Low-Level Waste
}

\section{MECRIVED}

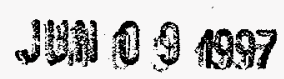

OSTI

\section{William E. Schwinkendorf}

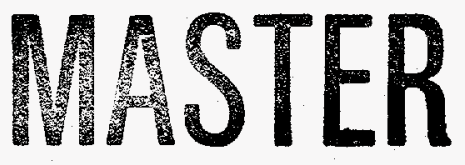

LOCKHEED MATTIN 
INEL-96/0247

\title{
Comparison of Alternative Treatment Systems for DOE Mixed Low-Level Waste
}

\author{
William E. Schwinkendorf
}

Published March 1997

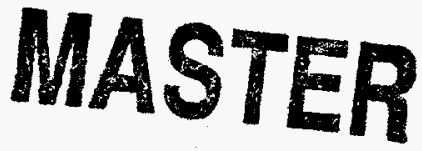

Idaho National Engineering Laboratory

Lockheed Martin Idaho Technologies Company

Idaho Falls, Idaho 83415

Prepared for the

U.S. Department of Energy

Assistant Secretary for Environmental Management

Under DOE Idaho Operations Office

Contract DE-AC07-94ID13223 


\section{DISCLAMMER}

Portions of this document may be illegible in electronic image products. Images are produced from the best available original document. 


\section{ABSTRACT}

From 1993 to 1996, the Department of Energy, Environmental Management, Office of Science and Technology (OST), has sponsored a series of systems analyses to guide its future research and development (R\&D) programs for the treatment of mixed low-level waste (MLLW) stored in the DOE complex. The two original studies were of $\mathbf{2 0}$ mature and innovative thermal systems. As a result of a technical review of these thermal system studies, a similar study of five innovative nonthermal systems was conducted in which unit operations are limited to temperatures less than $350^{\circ} \mathrm{C}$ to minimize volatilization of heavy metals and radionuclides, and de novo production of dioxins and furans in the offgas. Public involvement in the INTS study was established through a working group of 20 tribal and stakeholder representatives to provide input to the INTS studies and identify principles against which the systems should be designed and evaluated.

Pre-conceptual designs were developed for all systems to treat the same waste input $(2927 \mathrm{lbs} / \mathrm{hr})$ in a single centralized facility operating $\mathbf{4 0 3 2}$ hours per year for 20 years. This inventory consisted of a wide range of combustible and non-combustible materials such as paper, plastics, metals, concrete, soils, sludges, liquids, etc., contaminated with trace quantities of radioactive materials and RCRA regulated wastes. From this inventory, an average waste profile was developed for simulated treatment using ASPEN PLUS ${ }^{\oplus}$ for mass balance calculations.

Seven representative thermal systems were selected for comparison with the five nonthermal systems. This report presents the comparisons against the TSWG principles, of total life cycle cost (TLCC), and of other system performance indicators such as energy requirements, reagent requirements, land use, final waste volume, aqueous and gaseous effluents, etc. Estimated organic destruction efficiencies are developed and compared, and uncertainties in system performance identified. Research and development requirements for thermal and nonthermal systems are also identified.

The major cost element is operations and maintenance (O\&M), which is 50 to $60 \%$ of the TLCC for both thermal and nonthermal systems. Energy costs constitute a small fraction $(<1 \%)$ of the TLCCs. Equipment cost is only $3 \%$ of the TLCC indicating that process selection and R\&D funding should promote improved performance, reliability, and technical risk to minimize operations and maintenance labor rather than be based on the capital cost of the technology. Air pollution control (APC) systems, including $0 \& \mathrm{M}$, can be designed with functional redundancy to remove essentially all pollutants from either thermal and nonthermal systems at a small fraction ( 2 to $5 \%$ ) of TLCC indicating that the best available APC system should be used. Evaluation of subsystem costs demonstrate that receiving and preparation is the highest cost subsystem at about 25 to $30 \%$ of the TLCC for both thermal and nonthermal systems.

These studies found nonthermal TLCCs to be $\$ 1$ to $\$ 1.5$ billion more than thermal systems so there are no cost incentives to use nonthermal systems in place of thermal systems. Disposal volumes and costs for nonthermal process waste forms are a factor of three greater than those for thermal processes producing glass-ceramic waste forms. However, there may be other incentives to use nonthermal systems including significantly fewer air emissions. However, with a high performance APC system as described in these studies, the undesirable release of pollutants to the atmosphere should be almost nonexistent for both the thermal and nonthermal systems. 


\section{SUMMARY}

To gain insight into the type and extent of research and development required, the Department of Energy, Office of Science and Technology (OST), formerly Office of Technology Development, evaluated thermal treatment systems for DOE's mixed low-level waste (MLLW). As a result of reviews of this Integrated Thermal Treatment System (ITTS) study, a similar evaluation of nonthermal treatment systems, known as the Integrated Nonthermal Treatment System (INTS) study, was conducted. To allow comparison of the results of these studies, all systems were designed to process the same mixture of MLLW at the same rate, $2927 \mathrm{lbs} / \mathrm{hr}$ over 20 years, in a DOE-owned, contractor-operated facility operating with $60 \%$ availability. The waste input was based on processing the currently stored inventory of MLLW in a single, centralized treatment facility, and disposing of the resulting final waste forms in an engineered disposal facility. No newly generated waste was considered.

In the ITTS and INTS studies, various combinations of treatment technologies were integrated into systems designed to provide treatment for all waste feed streams. Twenty thermal systems and five nonthermal systems were evaluated. This report compares the results of the analyses of all five nonthermal systems with seven representative thermal systems. The systems compared here include the following:

- Thermal Systems

1. Rotary Kiln with Air for Combustion and Vitrification (System A-1)

2. Rotary Kiln with Oxygen for Combustion and Vitrification (System A-2)

3. Slagging Rotary Kiln (System A-7)

4. Rotary Kiln with Air for Combustion and Grout Stabilization (System A-8)

5. Plasma Furnace with Air for Combustion (System C-1)

6. Metal Melter with Reducing Atmosphere (System G-1)

7. Steam Reforming with Vitrification (System H-1)

- Nonthermal Systems

8. Mediated Electrochemical Oxidation Destruction of Organics, Thermal Desorption of Soil and Process Residue, and Primary Stabilization of Treated Waste and Untreated Debris with Grout (System NT-1)

9. Catalyzed Wet Oxidation Destruction of Organics; Thermal Desorption of Soils, Process Residue, and Debris; and Primary Stabilization with Grout (System NT-2)

10. Mediated Electrochemical Oxidation Destruction of Organics; Washing of Soils, 
Process Residue, and Debris; and Primary Stabilization with Grout (System NT-3)

11. Acid Digestion Destruction of Organics and Combustible (Soft) Debris, Washing of Soils and Debris, Thermal Desorption of Process Residue, and Primary Stabilization in Phosphate Bonded Ceramic (System NT-4)

12. Catalyzed Wet Oxidation Destruction of Organics and Combustible (Soft) Debris, Washing of Soils and Debris, Thermal Desorption of Process Residue, and Primary Stabilization in Grout (System NT-5)

In these studies, preconceptual equipment and facility designs and requirements were developed, and treatment and disposal costs determined. The nonthermal system designs were based on functional requirements for separation, decontamination, oxidation, immobilization and disposal of the various physical matrices and contaminants. Based on these preconceptual designs, mass balances were developed showing the quantities of final waste forms sent to disposal, gaseous and liquid effluents, and the amount of reagents required for treatment. In all of the studies, the waste that cannot be processed by the thermal or nonthermal primary treatment technology was routed through alternative treatments so that all of the waste was processed. Due to the complexity of the waste, it was necessary to establish several different processing lines for both thermal and nonthermal systems; however, because of the limited versatility of the nonthermal technologies, more complex systems with more unit operations were required for nonthermal treatment.

Although only $20 \%$ of the MLLW is combustible, all the waste can be treated by thermal processes to produce glass/ceramic waste forms for disposal and metal for disposal or recycling. About $70 \%$ of the total waste could be processed through the primary thermal treatment units with the remainder treated in special processes (e.g., mercury retort, and lead and metal melting and decontamination). The nonthermal systems, arbitrarily limited to a maximum temperature of $350^{\circ} \mathrm{C}$, require separation of the organic contaminants from the inorganic matrices for treatment in the organic destruction processes. Only $10 \%$ to $20 \%$ of the waste could be processed directly through the primary organic destruction processes (e.g., chemical oxidation), the remainder was processed through organic separation processes (e.g., thermal desorption or washing) or metal decontamination.

The thermal systems have the flexibility to process additional contaminated soils, which also serve as "glass formers" with about $30 \mathrm{wt} \%$ of the final waste residue consisting of the soil used as a glass former. Although the total life-cycle costs (TLCC) do not change for processing the contaminated soil, the unit cost of treatment in thermal systems can be reduced by approximately one dollar per pound (i.e., about 14\%) if additional waste in the form of contaminated soil is used for formation of the vitrified glass final waste form.

At the beginning of the INTS study, a Tribal and Stakeholder Working Group (TSWG) of 20 tribal and stakeholder representatives (Native Americans, state and local governments, citizens, environmental groups, and private companies) was formed to provide perspectives on the formulation of the studies and to provide input on the results. The group developed a set of "criteria principles" that reflected their concerns, which include minimize effluents; minimize effect on human health and the environment; minimize waste generation; address social, cultural, and spiritual considerations; provide adequate information for the TSWG to understand the advantages and disadvantages of the systems studied and to allow informed decisions to be made; and incorporate Tribal and Stakeholder involvement in the DOE procurement process. The principles are guidelines for good engineering practice and for addressing environmental and stakeholder concerns that can guide the evaluation of treatment systems. 
Performance, TLCC, and worker safety and public health were considered in these studies. Uncertainties in system performance and research and development needs were also addressed. This report presents the comparisons of performance, TLCC, and R\&D needs; safety and health issues are still being studied and will be reported separately.

Performance. Nonthermal systems produced roughly 2 to 3 times the volume of solid wastes requiring disposal as thermal systems, while the effluent gases from thermal systems were 5 to 20 times greater than from nonthermal systems. Although water is treated and recycled to meet the system requirements, most systems produce excess water that is treated and discharged.

For thermal systems, the final waste volume was approximately $30 \%$ of the volume of incoming waste, with the notable exception of the rotary kiln option in which grout was used for stabilization. In this case, the final waste volume was $70 \%$ of the incoming waste volume. Final waste volumes from nonthermal systems ranged from $80 \%$ to over $90 \%$ of the volume of incoming waste. The treated and stabilized waste sent to disposal varied from 36 to $43 \mathrm{ft}^{3} / \mathrm{hr}$ ( 3000 to $4000 \mathrm{lbs} / \mathrm{hr}$ ) for nonthermal stabilization and from 11 to $15 \mathrm{ft}^{3} / \mathrm{hr}(1450$ to $1700 \mathrm{lbs} / \mathrm{hr})$ for thermal stabilization processes.

Approximately the same amount of secondary residue (i.e., internally-generated salts stabilized in polymer) resulted from both nonthermal and thermal systems. Secondary residue varied from 2 to $4 \mathrm{ft}^{3} / \mathrm{hr}(200$ to $345 \mathrm{lbs} / \mathrm{hr})$ for nonthermal systems and was approximately $3 \mathrm{ft}^{3} / \mathrm{hr}(250 \mathrm{lbs} / \mathrm{hr})$ for thermal systems.

For nonthermal systems, carbon dioxide is the largest component of offgas, and for those thermal systems that used air for combustion, nitrogen is the largest constituent of gaseous emissions. The most positive aspect of the nonthermal systems' performance is the low volume of estimated offgas; however, the concentration of toxic contaminants in the offgas is not yet known from experimental data.

The components of thermal and nonthermal air pollution control (APC) systems are similar and perform similar functions. Both have been designed to decrease the offgas pollutants to a factor of ten below the regulatory emission requirements. The offgas from the main thermal treatment unit passes through a secondary combustion chamber to destroy any remaining organic material and is then cooled in the APC system by quenching. Baghouse filters followed by HEPA filters remove particulates from the offgas, and the flyash is sent to the vitrifier for stabilization. A scrubber is used to remove acid gases, a carbon filter is used to remove any remaining trace levels of organics, a sulfur-impregnated carbon filter is used to remove trace levels of mercury, and a HEPA filter is used to remove any remaining fine particulates that may contain condensed radionuclides before exhausting the offgas. For nonthermal systems the APC subsystem is much smaller because of the smaller amount of offgas generated by the nonthermal processes. Because the offgas from nonthermal systems is much cooler, a quench unit is not required; rather, the offgas passes through a series of condensers to remove water, acids, and organics. Particulate removal is accomplished in the same manner as with thermal systems, and a gas phase corona reactor (GPCR) is used to destroy remaining trace levels or organics (the GPCR is similar in function to the secondary combustion chamber in thermal systems). After the GPCR the systems are identical to thermal treatment APCs with a scrubber, carbon and sulfur-impregnated carbon filters, and HEPA filters.

The amount of water released by the thermal systems ranged from about 90 to $900 \mathrm{lbs} / \mathrm{hr}(0.2$ to 2 gpm), except for steam reforming and the rotary kiln system using grout stabilization which consumed water. Water was released from all of the nonthermal systems at rates of 50 to $800 \mathrm{lbs} / \mathrm{hr}(0.1$ to $1.6 \mathrm{gpm})$.

The aqueous waste treatment subsystems for thermal and nonthermal systems are identical except for size; the thermal system is larger since it must treat significantly more quantities of water from the quench and scrubber units in the APC subsystem. These systems are designed to remove gross immiscible organics, precipitate and filter inorganic contaminants, destroy soluble organics using UV photooxidation, 
and remove trace levels of organics and inorganics with activated carbon beds and ion exchange units, respectively. The resulting precipitates are stabilized in polymer and most of the water is recycled within the process. Performance of the aqueous waste treatment system is expected to meet or exceed regulatory requirements for water discharge.

Transportation. One of the concerns of the TSWG was truck traffic entering and leaving the treatment facility and its effect on the local community. The incoming waste, if shipped in trucks, would require about 270 truck loads per year. Thermal treatment systems, except for grout disposal, required the least amount of incoming process materials, about 75 truck loads per year, of which a large percentage was soil used for glass forming. However, the grout option required 210 truck loads per year for incoming grout. Nonthermal treatment systems required about 200 truck loads per year of incoming process materials and stabilizing agent. Thus, total truck traffic for a centralized facility using either type of system is 1 to 2 trucks per day entering and leaving the facility.

Costs. Total life-cycle costs, which include disposal but not storage, were developed so that comparisons could be made among the systems. The TLCCs show an expected trend but are probably no more accurate than $\pm 30 \%$. The TLCCs ranged from $\$ 2.1$ to $\$ 2.9$ billion for thermal treatments and from $\$ 3.6$ to $\$ 3.9$ billion for nonthermal treatments. The unit processing cost, excluding disposal cost, was about $\$ 8$ to $\$ 10 / 1 b$ for thermal systems and $\$ 12$ to $\$ 13 / \mathrm{lb}$ for nonthermal systems. No significant differences in cost occur among the thermal treatment technologies. Likewise, no significant differences in cost occurred among the nonthermal technologies. However, the TLCC of nonthermal systems averaged 40 to $60 \%$ higher than thermal systems.

Operations and maintenance costs are roughly 50 to $60 \%$ of TLCC in both types of system. Energy costs are only a small fraction ( $\leq 1 \%$ ) of the TLCC; however, average nonthermal system energy costs were approximately $10 \%$ of the average thermal system energy costs.

Nonthermal system costs are higher due to higher operating and maintenance costs, including waste sorting and preparation, and higher handling, packaging, and disposal costs due to greater final waste form volume. It remains to be seen whether further development and acceptable combinations of thermal and nonthermal technologies will lower the costs sufficiently for nonthermal treatments to be economically competitive. Further, the future development costs of nonthermal technologies will be higher than those of thermal technologies because of their present immature state of development. The development and technical support costs are estimated to be $\$ 100$ million for each thermal system studied, and vary from $\$ 130$ million to $\$ 210$ million for nonthermal systems.

For thermal systems, the percentages of TLCC attributable to various subsystems are approximately as follows: receiving and preparation, $25 \%$ to $30 \%$; disposal, $11 \%$ for systems using vitrification and $21 \%$ for systems using nonthermal stabilization; certification and shipping, $9 \%$ for thermal systems using vitrification and $14 \%$ for systems using nonthermal stabilization methods; and stabilization, $15 \%$ for systems that use a separate vitrifier and $6 \%$ for systems that combine thermal treatment with vitrification in one unit (e.g., slagging kiln and plasma furnace). Air pollution control included significant redundancy to ensure compliance with all regulations, even during upset conditions, yet the APC costs are a small fraction (about 5\%) of TLCC for thermal systems. This implies that using the best APC system available would have a minimal cost impact, and local issues associated with implementation and permitting might be minimized.

For nonthermal systems, the percentages of TLCC attributable to various subsystems are approximately as follows: receiving and preparation, $25 \%$; disposal, $21 \%$; certification and shipping, $12 \%$; and stabilization, $12 \%$. Air pollution control costs are about $2 \%$ of TLCC for nonthermal systems, 
approximately one-half that for thermal systems.

Comparing the various thermal systems against a rotary kiln treatment with grout stabilization, considered current technology (System A-8), the cost saving potential ranges from $\$ 400$ to $\$ 750$ million through application of innovative thermal technologies. If future waste volumes are included, the cost savings may increase to $\$ 1$ to $\$ 1.5$ billion. Nonthermal systems' TLCCs are approximately $\$ 1$ billion more than that of System A-8. However, because some of the major cost elements of nonthermal systems are based on the high volume of waste sent to disposal (e.g., certification and shipping and disposal costs), combining vitrification with nonthermal treatment to decrease the waste disposal volume may also achieve some cost savings. These hybrid systems are the subject of an ongoing study.

One of the major cost factors in both thermal and nonthermal systems is receiving and preparation. Some systems require minimum pretreatment such as sorting and shredding (e.g., rotary kiln and plasma furnace), whereas others require considerable pretreatment (e.g., steam reforming and all the nonthermal systems). Reducing characterization and sorting costs by half can achieve a cost savings of $\$ 350$ to $\$ 450$ million. Improvements in system availability from the assumed $4032 \mathrm{hrs} / \mathrm{yr}$ to $5850 \mathrm{hrs} / \mathrm{yr}$ by increased reliability and decreased maintenance requirements can achieve a savings of approximately $\$ 370$ million.

Personnel requirements are about 250 to 300 full-time equivalents (FTEs) for the thermal treatment facilities and 400 FTEs for the nonthermal facilities. The estimated higher personnel requirements for the nonthermal systems is the major factor in their higher costs. Greater personnel requirements are due to the increased characterization and sorting requirements; larger number of unit operations, which require more operators and maintenance personnel; and larger volume of waste sent to disposal. These estimated personnel requirements point to areas needing detailed engineering study and to research and development opportunities for cost savings.

Technical Maturity. All of the nonthermal technologies evaluated have been tested at bench scale and a few (thermal desorption, washing, and mediated electrochemical oxidation) at limited pilot scale; one technology, ultraviolet light oxidation, is used commercially for organic contaminants in aqueous waste streams. The thermal treatment technologies have been tested in a pilot plant demonstration or are already used in industry for hazardous waste treatment. At least 5 years and up to 10 years of additional $R \& D$ is expected to be required to bring the nonthermal technologies to an equivalent state with many of the thermal technologies.

Although effective treatment systems using only technologies that are nonthermal (operate at $350^{\circ} \mathrm{C}$ or less) seem to be feasible, schedule risks and uncertain environmental performance and compliance with regulatory requirements provide significant challenges. The nonthermal technologies studied have only limited performance information available, and most of that was obtained under relatively ideal testing conditions. Destruction efficiency and process throughput with actual waste streams, where multiple contaminants are present in very complex mixtures, are unknown. Some data indicate difficulty with some of the systems achieving complete destruction for certain contaminants, and separation processes leave $1 \%$ or more of the incoming organics in the final solid waste for disposal.

Future R\&D. Information acquired during the studies, and the results of the studies, indicate the following needs: 
1. Air Pollution Control Test Bed. Performance information is needed to specify the components, and the sequence of components, in the APC for thermal systems. In particular, information is needed to decide whether dry particulate removal should occur before or after wet scrubbing to remove chlorides. Key issues are: 1) control and/or prevention of dioxin/furan formation, 2) mercury removal, 3) desirable form and disposal method for mercury, and 4) the effectiveness of the backup carbon filters to remove dioxins/furans and mercury. To assess the effectiveness of the APC subsystem, the type of particulates and gases must be known. Tests need to be coupled with on-line measurements using continuous emission monitors to evaluate performance in normal and abnormal (upset) operating conditions.

Capture of offgas emissions, with sampling and delayed release to prevent emission of contaminants, did not seem to offer sufficient advantages in the ITTS study, but performance data were lacking. Criteria for hold-and-release need to be established, and performance data are needed to determine if there are sufficient advantages to pursue this approach. However, reliable continuous emission monitors with adequate feedback control and offgas system operation to prevent emissions in case of an upset may eliminate the need for this approach.

2. Water Pollution Control (WPC) Test Bed. Although much information on the removal of specific radionuclides and toxic materials is available, more information is needed on an assembled subsystem that uses the various treatments sequentially to remove suspended particulates, dissolved radionuclides and hazardous materials, and residual organics, if any. The effectiveness of the sequence of treatment steps and the interaction among the treatment steps needs to be known for appropriate application of the technologies. In addition, the most appropriate technologies for the treatment of liquids needs to be determined unless only systems that do not produce liquid effluent are used.

3. Selection and Testing of Final Waste Forms. Although TLCC numbers indicate the value of vitrified forms, such high-temperature processes are expected to produce enough volatile materials to require a complementary, low-temperature waste form such as polyethylene to stabilize soluble and volatile metal salts that are difficult to contain in a high temperature glass/ceramic waste form. Tests and data on such separate waste forms are needed to establish their capability to contain radioactive and hazardous materials. The ability to delist all final waste forms and the incentives to do so need to be established. Accurate data for risk assessments are needed to establish the effectiveness of risk reduction by using polyethylene or other low temperature forms.

The effectiveness of the vitrified, ceramic, and polymer waste forms in reducing long-term risk needs to be established and compared to acceptable release rates (which are yet to be established, i.e., how good is good enough?). The effects of surface area (e.g., cracks) on behavior during disposal, including release rates, needs to be analyzed: This provides perspective on whether gem-size glass or highly fractured monoliths are preferable or whether the gems should be encapsulated by using the polyethylene fraction from the secondary waste (polyethylene containing the soluble and volatile metal salts) to gain a better or equivalent long-term performance.

4. Organic Destruction Efficiencies. In nonthermal systems, the primary treatment unit usually destroys less of the organic contaminants than that in thermal systems. Partial decomposition products may exist in the treated waste and their presence and characteristics needs to be determined for the complex waste streams characteristic of DOE's MLLW. The impact of 
reaction rates on throughput, and the presence and effect of reaction by-products on the longterm performance of the final waste form is unknown and needs to be determined. A potentially acceptable alternative is to feed the nonthermal residuals to a vitrifier; however, the treatment effectiveness and the acceptable level of organics in the residuals needs to be established.

5. Operating Characteristics. The size and composition of waste that can be safely fed to the treatment systems, and thereby the extent of sorting that is required for incoming waste, needs to be established.

6. Volatilization of Radionuclides and Metals. Volatilization is minor for nonthermal systems. For thermal systems, more theoretical and experimental data are needed to support application of the systems to various types of waste. A closely related question is the method of removal of chloride since many of the volatile metals form chlorides. Furthermore, operation under reducing or oxidizing mode influences the volatility. Although considerable data exist, integrated test data involving the complexities of gases from MLLW destruction are not available.

7. Heating Source. All thermal treatment methods require a source of heat, e.g., a plasma torch, induction or resistance heating, flame, or electric arc. The differences in the generation of particulate, volatile metals, and organics may be significant and need to be established to define the inputs to the APC and WPC subsystems.

8. Oxidizing or Reducing Operation. Major issues due to differences in operating mode that require further investigation include: 1) production of dioxins or furans (do reducing or starved air operations lead to production of dioxins or furans and, if so, under what conditions); 2) management of volatile oxides, chlorides, or metals throughout the system as a function of the operating mode; 3) post treatment (second stage) oxidation of gases before release; and 4) management of operating systems to maintain non-explosive concentrations of gases. Although either operating condition may be acceptable, the differences need to be known well enough to understand the impacts and requirements of using either oxidizing or reducing conditions.

9. Future Systems Engineering Analysis. Because many of the conditions in the ITTS and INTS studies were fixed, some variations in system design and operation still need to be investigated. These include operating time, processing rates, waste composition changes, process capability to handle all types of special waste, split operations where part is done at one site and the rest at another site, impacts of transportation and storage, and impacts of variations in disposal requirements (e.g., delisting of all waste and non-engineered disposal versus disposal using special engineered barriers such as grout or clay).

Relevance to Tribal and Stakeholder Principles. Not all TSWG principles are satisfied by a single treatment system. For example, use of nonthermal stabilization technologies to satisfy the criterion "minimize effluents" decreases the amount of gaseous effluent at the expense of increased disposal volume using a waste form with less satisfactory performance. The ability of nonthermal systems to treat MLLW to the Universal Treatment Standards (UTS) is unknown, and their performance varies with the type of contaminant. Although thermal systems have higher gaseous effluent, with some potential to carry contaminants into the discharge, their high temperatures make them efficient in destroying organic contaminants to the required UTS, and efficient APC systems are available to prevent undesirable releases. The stakeholder issue that needs to be resolved is determining which type of system has the most (or least) 
deleterious effect on the environment. Tradeoffs between gaseous, liquid, and solid effluents, and their short- and long-term effects on the environment and public health, need to be understood.

In general, both thermal and nonthermal systems can be designed and engineered to meet the TSWG principles, although, as indicated above, meeting one principle may affect compliance with another. Proper design and operational controls will mitigate the potential for accidents or upset conditions. The preconceptual designs of the air pollution control subsystems and the aqueous waste treatment subsystems were developed to decrease hazardous effluent below the regulatory discharge requirements. Land use is comparable for thermal and nonthermal treatment facilities ( $\sim 50$ to 57 acres), and the disposal site varies from 150 acres for thermal systems to 210 acres for nonthermal systems. Truck traffic for delivery of waste and process chemicals appears minimal at approximately 1 to 2 trucks per day, but the acceptability of such traffic is a local issue.

Value of Tribal and Stakeholder Involvement. The INTS approach was to provide tribes and the public an opportunity to address future research and development work before decisions are made. Participation in development of selection criteria and in the review of technical and non-technical findings of the ITTS and INTS studies allowed the TSWG representatives to understand the issues and trade-offs associated with developing, evaluating, and selecting waste treatment systems. These interactions provided an opportunity for non-technical and technical participants in the INTS study to work together and develop increased understanding and credibility on all sides of the issue of waste treatment. The technical members of the INTS study had the opportunity to learn more about tribal and stakeholder issues and how they might apply to the technical tasks associated with technology assessment and selection.

Value of Systems Analysis. Studying a complete system and evaluating its total life cycle has provided perspectives on the importance of using the systems approach. Only through this thorough analysis have some of the R\&D needs come to light, and aspects of the systems have been identified that have minimal impact on cost but may have a large impact on performance or public acceptance. These studies have shown that capital costs are small relative to other factors in the total life-cycle cost of these systems, and that emphasis should be placed on system performance and reliability. Cost reduction efforts should be focused on operations and maintenance, including reliability and efficiency of operations such as characterization and sorting, and minimizing waste disposal volume as long as the potential release from the waste form can be kept low. Knowledge of the technical deficiencies provides guidance for R\&D programs. Knowledge of the systems provide the background for potential proposals, procurement specifications, and the evaluation of competitive bids in the procurement process. 


\section{ACKNOWLEDGMENTS}

The author acknowledges the contributions of the following individuals in preparing, reviewing and producing this report: Carl Cooley of the U.S. Department of Energy for his leadership and guidance; Bill Quapp of Nuclear Metals, Inc. (formerly of Lockheed Martin Idaho Technologies company); Blaine Brown and Tom Bechtold of Lockheed Martin Idaho Technologies company; Gary Knight of the Waste Policy Institute; and Chuck Biagi and Julia Vetromile of Morrison Knudsen Corporation. The review and comments by members of the Technical Support Group (TSG), the Tribal and Stakeholders Working Group (TSWG), and the Independent Peer Review Group (IPRP) are also greatly appreciated. 


\section{CONTENTS}

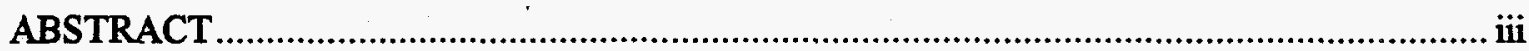

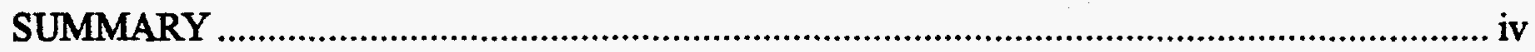

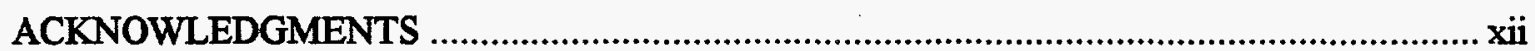

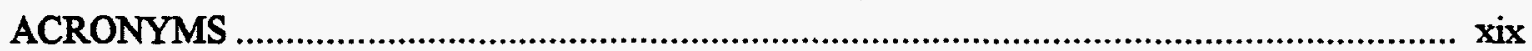

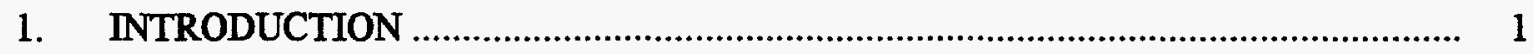

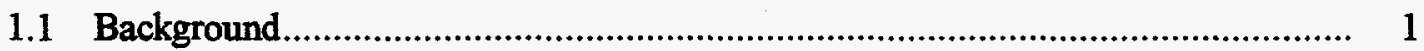

1.2 Report Organization .................................................................................... 5

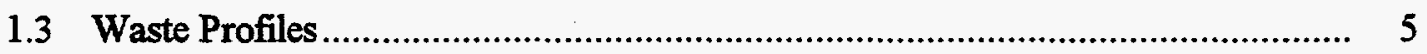

1.4 System Selection ……............................................................................. 8

2. SYSTEM DESCRIPTIONS AND WASTE DISTRIBUTIONS .................................... 9

2.1 Thermal Systems ......................................................................................... 9

System A-1: Rotary Kiln with Air .................................................................. 9

System A-2: Rotary Kiln with Oxygen........................................................... 11

System A-7: Slagging Rotary Kiln............................................................ 11

System A-8: Rotary Kiln with Air and Grout Stabilization................................ 11

System C-1: Plasma Furnace....................................................................... 11

System G-1: Molten Metal ....................................................................... 11

System H-1: Steam Gasification ........................................................................ 17

2.2 Nonthermal Systems ....................................................................................... 17

2.3 Summary of Waste Distributions ....................................................................... 24

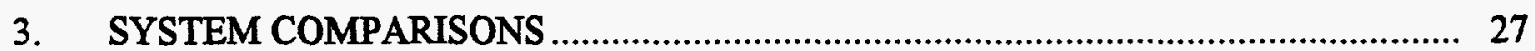

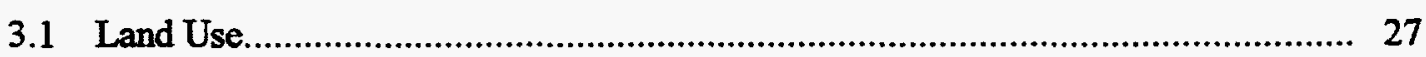

3.1.1 Treatment Facility Land Use .............................................................. 27

3.1.2 Disposal Land Use ............................................................................ 30

3.2 Effluent Comparison ..................................................................................... 30

3.2.1 Gaseous Effluent ........................................................................ 33

3.2.2 Wastewater Effluent ...................................................................... 37

3.2.3 Solids to Disposal ......................................................................... 37

xiii 
3.3 Final Waste Form

3.4 Contaminant Destruction and Removal Performance ....................................... 47

3.4.1 Thermal Treatment Systems..................................................... 47

3.4.2 Nonthermal Treatment Systems........................................................ 48

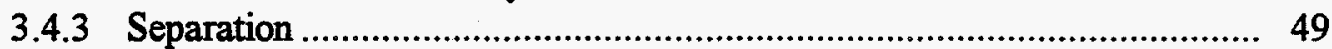

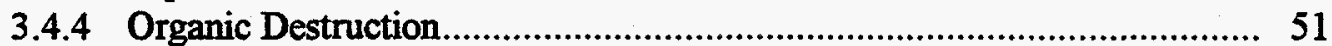

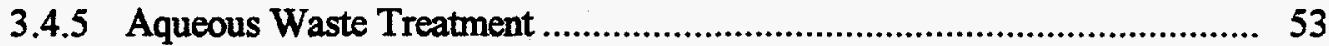

3.4.6 Air Pollution Control Systems ............................................................ 53

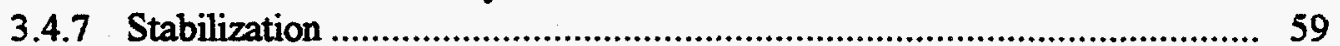

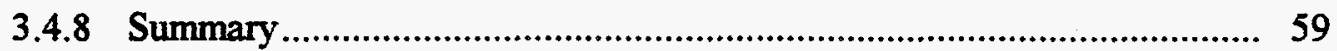

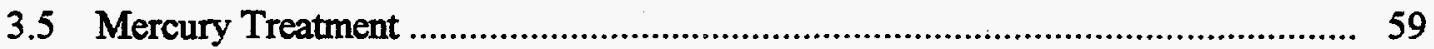

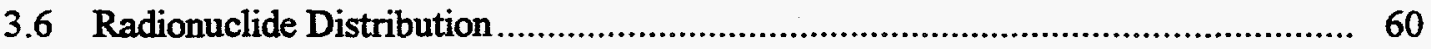

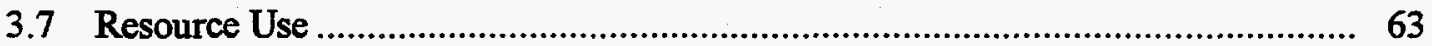

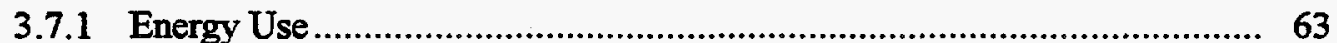

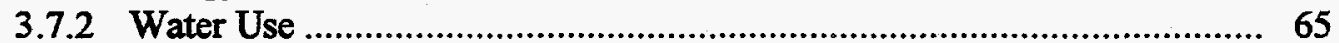

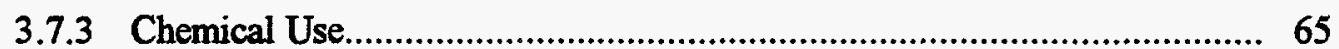

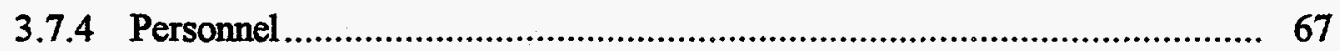

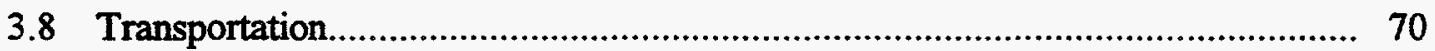

3.9 Comparison of Subsystem Costs and Material Balances ................................... 73

3.9.1 Receiving and Preparation................................................................. 78

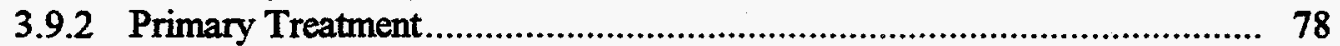

3.9.3 Air Pollution Control Systems........................................................... 82

3.9.4 Aqueous Waste Treatment Systems.................................................. 84

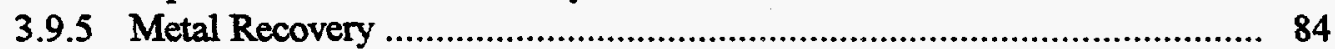

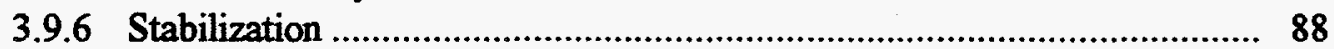

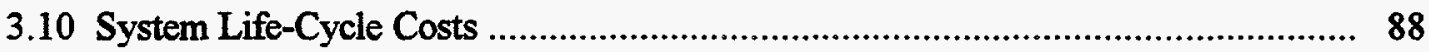

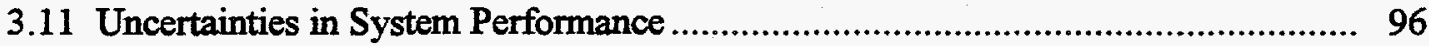

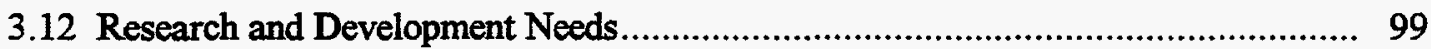

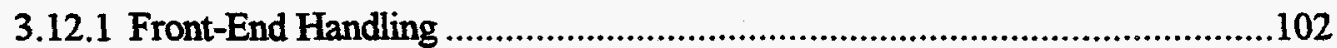

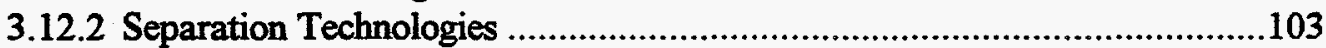

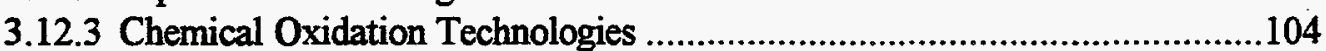

3.12.4 Thermal Destruction Technologies ....................................................104

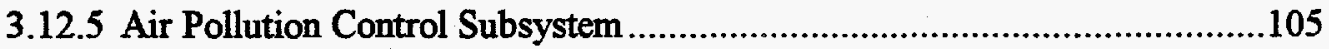

3.12.6 Aqueous Waste Treatment Subsystem ................................................106

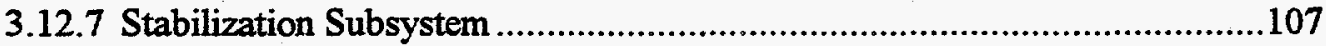




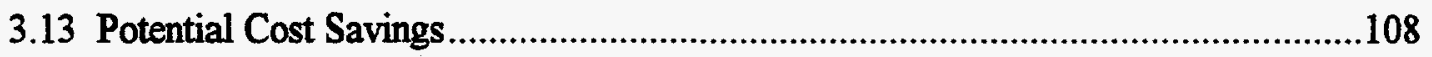

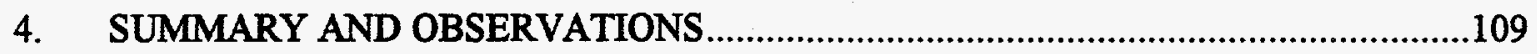

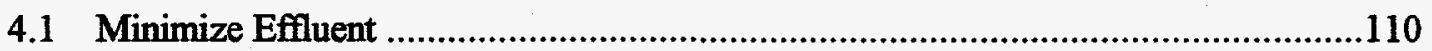

4.1.1 Minimize Effluent that can Carry Hazardous Materials that Cause Adverse Environmental Consequences..............................................110

4.2 Minimize Effects on Human Health and the Environment ...................................110

4.2.1 Minimize Exposure Now......................................................................110

4.2.2 Minimize Exposure in the Future......................................................110

4.2.3 Minimize Potential for Release of Hazardous Materials from Final Storage/Disposal Products .............................................................111

4.2.4 Minimize Potential for Accidents in the System ..................................111

4.3 Minimize Waste Generation...............................................................................111

4.3.1 Minimize Creation of New Hazardous Material by Treatment....................111

4.3.2 Minimize Final Waste Volume/Amount for Storage/Disposal....................111

4.4 Address Social, Cultural, and Spiritual Considerations...................................112

4.4.1 Minimize Land Use for Disposal/Storage ..........................................112

4.4.2 Waste Should be Disposed in a Retrievable Manner ................................112

4.4.3 Stable Waste Forms for Storage and Long Term Disposal .......................112

4.4.4 Reflect Special Site Considerations ...................................................112

4.4.5 Reflect Cultural Values.................................................................112

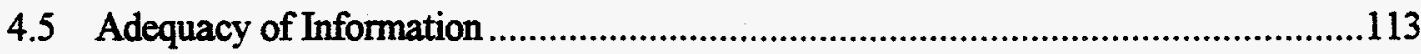

4.5.1 Criteria for Evaluating Systems Should be Flexibly Applied ...................113

4.5.2 Provide Better Information on Health and Safety ...................................113

4.5.3 Provide Better Information on Performance ............................................113

4.5.4 Focus on Existing Stored Waste, Add Projected Impact of Future Waste ...113

4.5.5 Communicate When Systems of Technologies Could be Implemented ........113

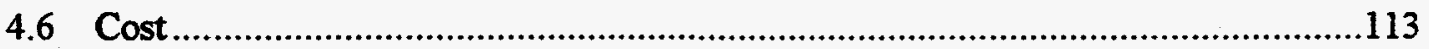

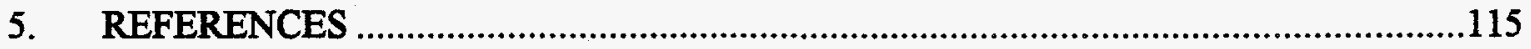




\section{FIGURES}

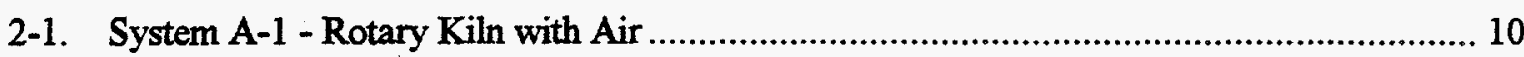

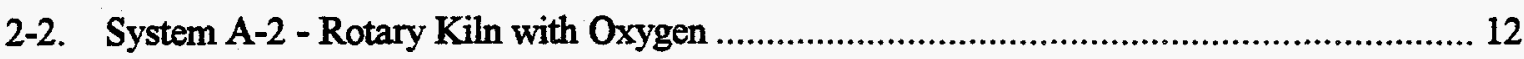

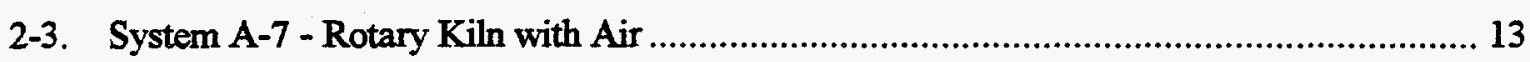

2-4. System A-8 - Rotary Kiln with Air and Grout Stabilization...................................... 14

2-5. System C-1 - Plasma Hearth Furnace with Air..................................................... 15

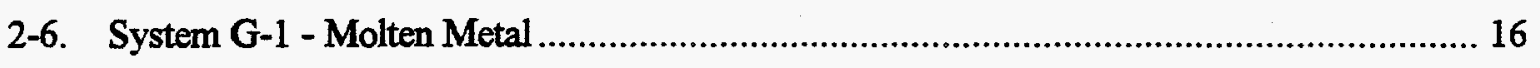

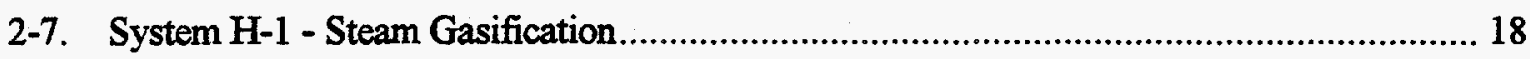

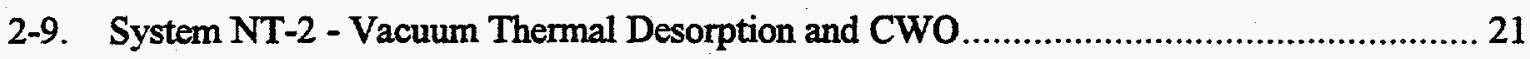

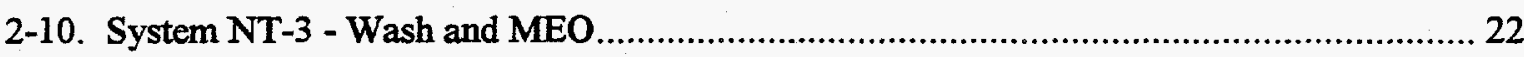

2-11. System NT 4 - Combined Treatment with Acid Digestion ........................................ 23

2-12. System NT-5 - Combined Treatment with CWO ............................................... 25

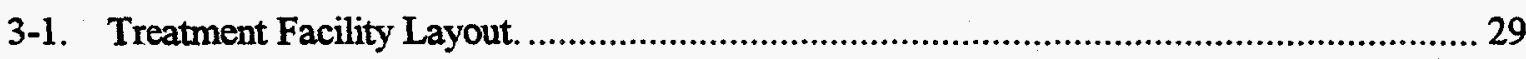

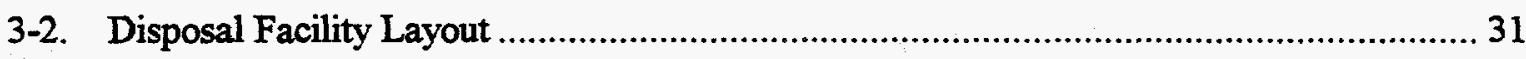

3-3. Offgas composition from thermal systems...................................................... 35

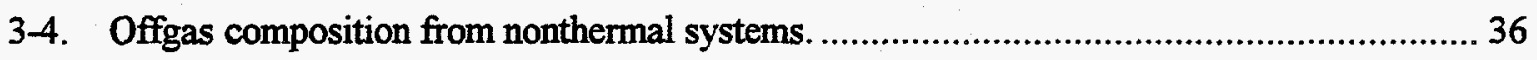

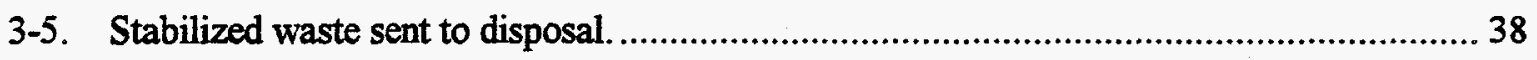

3-6. Stabilized waste volume as a percent of waste volume entering the treatment facility. ....... 40

3-7. Stabilized Waste Form as a percent by volume of waste sent to disposal for each system.

3-8. Organic destruction efficiencies for the chemical oxidation processes combined with

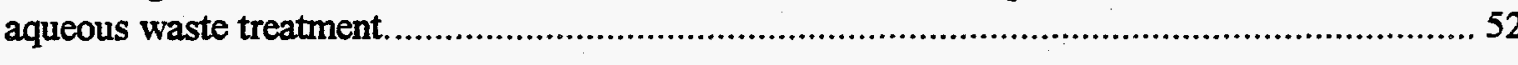

3-9. Organic destruction and removal efficiencies for the aqueous waste treatment subsystem.

3-10. Conservative estimate of destruction and removal efficiencies at each stage of treatment for a typical air pollution control subsystem for mixed waste thermal treatment. 
3-11. Organic destruction and removal efficiencies for a typical nonthermal air pollution control subsystem.

3-12. Incoming truck traffic (trucks per year).

3-13. Life-cycle costs by work breakdown element. 93

3-14. Estimated level of development for thermal technologies. 97

3-15. Estimated level of development for nonthermal technologies. 98

\section{TABLES}

1-1. Systems included in the Integrated Thermal Treatment System Study

1-2. Systems included in the Integrated Nonthermal Treatment System Study 3

1-3. Tribal and Stakeholder Principles and Issues of Concern .....................................

1-4. Total System Input for Thermal and Nonthermal Systems .................................... 6

1-5. Redistribution of ITTS Throughput into INTS Subsystems ................................. 7

2-1. Percent of waste distributed to thermal treatment subsystem ................................ 26

2-2. Percent of Waste Distributed to Nonthermal Treatment Subsystems ........................ 26

3-1. Treatment Facility Land Use Requirements ..................................................... 28

3-2. Disposal Site Land Use Requirements ........................................................... 28

3-3a. Effluent from Thermal Systems (lbs/hr) .......................................................... 32

3-3b. Effluent From Nonthermal Systems (lbs/hr) .................................................. 32

3-4a. Composition of offgas from thermal systems ................................................... 34

3-4b. Composition of offgas from nonthermal systems............................................. 34

3-5. Ratios of waste input volumes to volumes of waste sent to disposal ......................... 39

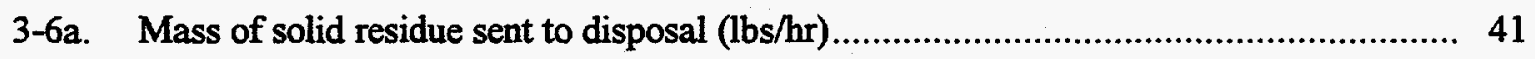

3-6b. Volume of solid residue sent to disposal (cubic feet/hr) .................................... 42

3-7. Potential contaminants in the aqueous waste and mitigating design features ............... 55

3-8. Potential Contaminants in the Primary Treatment System Offgas and Design Features to Minimize Release to the Environment

3-9. Radionuclide input to thermal and nonthermal systems ................................. 61 
3-10. Radionuclide partitioning into output streams .............................................. 62

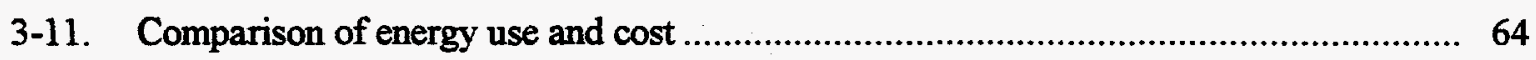

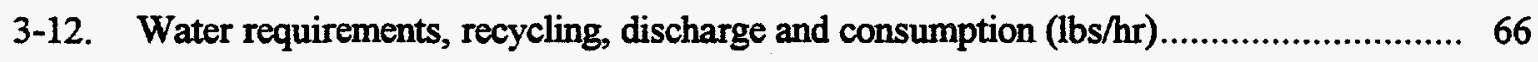

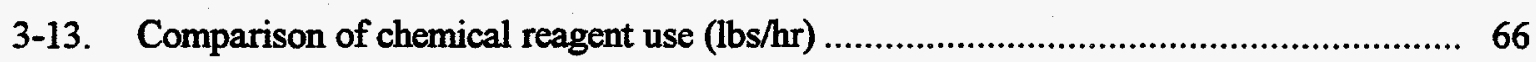

3-14a. Typical thermal treatment system operational personnel requirements (FTEs) ............. 68

3-14b. Typical nonthermal treatment system operational personnel requirements (FTEs)........ 69

3-15. Comparison of truck traffic associated with the treatment facilities

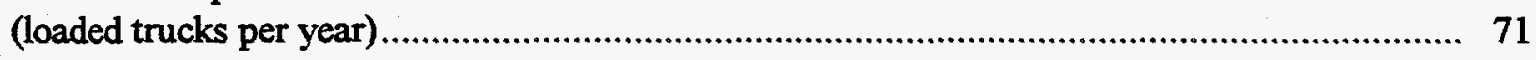

3-16a. Thermal subsystem costs (\$ millions) and percentages of total costs ...................... 74

3-16b. Nonthermal subsystem costs ( $\$$ millions) and percentages of total costs .................. 75

3-17a. Thermal capital costs ( $\$$ millions) by subsystem and percentages of

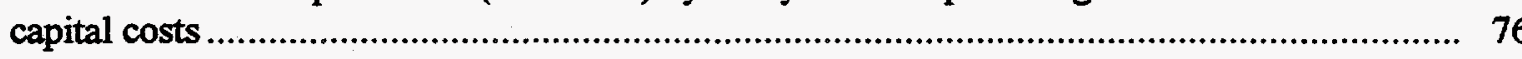

3-17b. Nonthermal capital costs ( $\$$ millions) by subsystem and percentages of capital costs 77

3-18a. Mass balance for the thermal primary treatment subsystem $(\mathrm{lbs} / \mathrm{hr})$........................ 79

3-18b. Mass balance for the nonthermal primary treatment subsystem (lbs/hr) .................... 80

3-19a. Mass balance for the thermal APC subsystems (lbs/hr) ........................................ 83

3-20a. Mass balance for the thermal aqueous waste treatment subsystems $(\mathrm{lbs} / \mathrm{hr})$............... 85

3-20b. Mass balance for the nonthermal aqueous waste treatment subsystems ( $\mathrm{bs} / \mathrm{hr}$ ) ......... 85

3-2la. Mass balance for the thermal metal decontamination and recovery subsystems

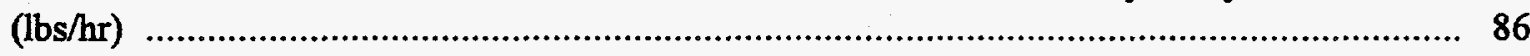

3-21b. Mass balance for the nonthermal metal decontamination and recovery subsystems

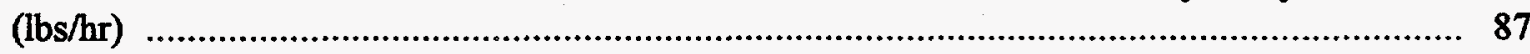

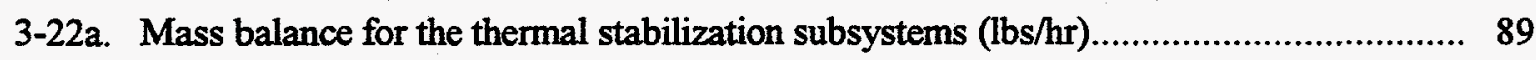

3-22b. Mass balance for the nonthermal stabilization subsystems $(\mathrm{lbs} / \mathrm{hr})$.......................... 90

3-23a. Thermal system life-cycle costs (\$ millions) and percentage of total costs ................. 91

3-23b. Nonthermal system life-cycle costs (\$ millions) and percentage of total costs .............. 92

3-24. Uncertainties in the performance of subsystems ....................................................100

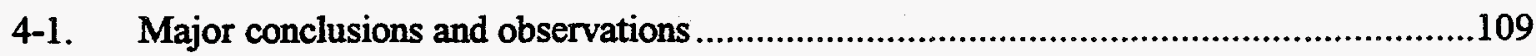




\section{ACRONYMS}

${ }^{\circ} \mathrm{C}$

${ }^{\circ} \mathrm{F}$

${ }^{3} \mathrm{H}_{2} \mathrm{O}$

$\mathrm{AgNO}_{3}$

APC

ASPEN Plus

BDAT

BNL

BSG

BTU

$\mathrm{CaO}$

CEM

CERCLA

CFR

$\mathrm{Cl}_{2}$

$\mathrm{CO}_{2}$

$\mathrm{Cs}_{2} \mathrm{O}$

$\mathrm{CsCl}$

$\mathrm{Cu}$

CWO

DOE

DRE

EPA

$\mathrm{FeCl}_{3}$

$\mathrm{ft}$
Degree centigrade

Degree Fahrenheit

Tritiated water.

Silver Nitrate

Air pollution control

ASPEN PLUS computer model

Best demonstrated available technology

Brookhaven National Laboratory

borosilicate glass

British thermal unit

calcium oxide

Continuous emission monitors

Comprehensive Environmental Response, Compensation and Liability Act

Code of Federal Regulations

Chlorine

Carbon Dioxide

Cesium Oxide

Cesium Chloride

Copper

Low temperature vacuum thermal desorption with catalyzed wet oxidation

U.S. Department of Energy

Destruction and removal efficiency

U.S. Environmental Protection Agency

Ferric Chloride

Feet 
FTE

GPCR

gpm

$\mathrm{H}_{2} \mathrm{O}$

$\mathrm{H}_{2} \mathrm{O}_{2}$

$\mathrm{HCl}$

HEPA

$\mathrm{HNO}_{3}$

hr

IEB

INEL

INTS

IPRP

ITTS

$\mathbf{k W h}$

$\mathrm{lb}$

LDR

MEO

MLLW

$\mathrm{N}_{2}$

$\mathrm{NaOH}$

$\mathrm{nCi} / \mathrm{g}$

NEPA

$\mathrm{ng} / \mathrm{L}$

$\mathrm{NH}_{3}$

$\mathrm{NiCl}_{2}$
Full time equivalent (employee)

gas phase corona reactor

Gallons per minute

Water

Hydrogen Peroxide

Hydrogen chloride

High efficiency particulate air (filter)

Nitric Acid

Hour

Iron-enriched basalt

Idaho National Engineering Laboratory

Integrated Nonthermal Treatment System

Independent Peer Review Panel

Integrated Thermal Treatment System

Kilowatt per hour

Pound

Land Disposal Restrictions

Mediated electrochemical oxidation

Mixed low-level waste

Nitrogen

Sodium Hydroxide

NanoCurie per gram

National Environmental Policy Act

Nanogram per liter

Ammonia

Nickel Chloride 


\begin{tabular}{ll} 
NiO & Nickel Oxide \\
NO $_{x}$ & Nitrogen Oxide \\
O\&M & Operating and maintenance \\
$\mathrm{O}_{2}$ & Oxygen \\
OST & Assistant Secretary for Environmental Management, Office of Science and \\
OST & Technology, \\
pH & Office of Science and Technology \\
PIC & Potential of hydrogen \\
PNL & Products of incomplete combustion \\
ppb & Pacific Northwest Laboratory \\
ppm & Parts per billion \\
psia & Parts per million \\
psig & Pounds per square inch absolute \\
PuO & Pounds per square inch guage \\
R\&D & Plutonium Oxide \\
RCRA & Research and Development \\
SCC & Resource Conservation and Recovery Act \\
syngas & Secondary combustion chamber \\
System A-1 & synthetic gas \\
System A-2 & Rotary Kiln/Air: Rotary Kiln with Air for Combustion and Vitrification \\
System A-7 & Rotary Kiln/Oxygen: Rotary Kiln with Oxygen for Combustion and Vitrification \\
System A-8 & Slagging Rotary Kiln \\
System C-1 & Rotary Kiln/Grout: Rotary Kiln with Air for Combustion and Grout Stabilization \\
System G-1 & Plasma Furnace with Air for Combustion \\
System H-1 & Metal Melter with Reducing Atmosphere \\
\hline
\end{tabular}


System NT-1

System NT-2

System NT-3

System NT-4

System NT-5

TLCC

TSG

TSWG

$\mathrm{UO}_{2}$

UTS

UTS

UV

WPC

yr
Grout Debris: Mediated Electrochemical Oxidation Destruction of Organics, Thermal Desorption of Soil and Process Residue, and Primary Stabilization of Treated Waste and Untreated Debris with Grout

Thermal desorption: Catalyzed Wet Oxidation Destruction of Organics; Thermal Desorption of Soils, Process Residue, and Debris; and Primary Stabilization with Grout

Wash: Mediated Electrochemical Oxidation Destruction of Organics; Washing of Soils, Process Residue, and Debris; and Primary Stabilization with Grout

Acid Digestion: Acid Digestion Destruction of Organics and Combustible (Soft) Debris, Washing of Soils and Debris, Thermal Desorption of Process Residue, and Primary Stabilization in Phosphate Bonded Ceramic

Catalized Wet Ox: Catalyzed Wet Oxidation Destruction of Organics and Combustible (Soft) Debris, Washing of Soils and Debris, Thermal Desorption of Process Residue, and Primary Stabilization in Grout

Total life-cycle costs

Technical Support Group

Tribal and Stakeholders Working Group

Uranium Oxide

Universal Treatment Standards

Universal Treatment Standards

Ultraviolet light

Water Pollution Control

Year 


\section{Comparison of Alternative Treatment Systems for DOE Mixed Low-Level Waste}

\section{INTRODUCTION}

\subsection{Background}

The U.S. Department of Energy's (DOE) Assistant Secretary for Environmental Management, Office of Science and Technology, commissioned an integrated thermal treatment system (ITTS) study and an integrated nonthermal treatment system (INTS) study to assess alternative systems for treating contacthandled, alpha and nonalpha radioactive mixed low-level waste (MLLW). These studies are applicable only to waste containing Resource Conservation and Recovery Act (RCRA) hazardous materials and lowlevels of radioactivity. The MLLW in the DOE complex consists of organic and inorganic solids and liquids comprising a wide variety of materials contaminated with hazardous and radioactive substances. Treatment systems are needed that will destroy the organic contaminants by converting them to nontoxic substances such as carbon dioxide and water. Other operations are needed to stabilize the treatment residues, inorganic contaminants, and radionuclides prior to disposal. Regulations promulgated by both DOE and the U.S. Environmental Protection Agency (EPA) govern the storage, treatment, and disposal of these wastes.

The ITTS study, started in the fourth quarter of 1993, was a systematic engineering evaluation of a variety of MLLW thermal treatment systems. Preconceptual designs (process flows diagrams, facility layouts, equipment lists, and material mass balances) were developed, and the environmental performance and life-cycle costs for the systems were calculated. To address public concerns regarding emissions from thermal treatment facilities such as incinerators, DOE commissioned an evaluation of nonthermal systems in the INTS study, which began the third quarter of 1995. For the purposes of these studies, thermal processes were arbitrarily defined as operating above $350^{\circ} \mathrm{C}\left(662^{\circ} \mathrm{F}\right)$, and nonthermal processes as operating below $350^{\circ} \mathrm{C}$.

To allow a direct comparison of thermal and nonthermal systems, the INTS study used the same bases as were used in the ITTS study, e.g., waste type and processing rate, performance requirements (in accordance with DOE and EPA regulations), facility design requirements (to meet DOE safety and radiation regulations), and costing assumptions. Waste feed rates are based on having a single integrated treatment facility operating 4,032 hours per year for 20 years (equivalent to operating 280 days/year, 24 $\mathrm{hr} /$ day at $60 \%$ availability). Where possible, metals are decontaminated (either by surface blasting or by metal melting) for recycle within the DOE complex. No economic credit is taken for recycling, nor is a disposal cost assigned. Other bases and assumptions are described in the reports on these studies. ${ }^{14}$

Phases 1 and 2 of the ITTS study evaluated nineteen systems; ${ }^{1,2}$ an additional system involving a thermal destruction technology and a nonthermal grout stabilization technology identical to that used with the nonthermal systems was recently included. ${ }^{3}$ Five nonthermal systems were studied and the results are reported in Reference 4 . The twenty thermal systems and five nonthermal systems evaluated in these studies are listed in Tables 1-1 and 1-2, respectively. 
Table 1-1. Systems included in the Integrated Thermal Treatment System Study.

\section{Phase 1}

Rotary kiln with air for combustion and dry/wet APC A-1

Rotary kiln with oxygen for combustion and dry/wet APC $\quad$ A-2

Rotary kiln with air for combustion and wet APC A-3

Rotary kiln with oxygen for combustion and $\mathrm{CO}_{2}$ retention $\quad \mathrm{A}-4$

Rotary kiln with air for combustion and polymer stabilization A-5

Rotary kiln with air for combustion and maximum recycling $\quad$ A-6

Indirectly heated pyrolyzer with oxygen and dry/wet APC $\quad$ B-1

Plasma hearth furnace with air and dry/wet APC $\quad$ C-1

Fixed hearth with oxygen and $\mathrm{CO}_{2}$ retention $\quad$ D-1

Debris desorption and grouting with rotary kiln for combustibles $\quad$ E-1

Phase 2

$\begin{array}{ll}\text { Slagging rotary kiln } & \text { A-7 }\end{array}$

$\begin{array}{ll}\text { Plasma furnace with } \mathrm{CO}_{2} \text { retention } & \mathrm{C}-2\end{array}$

Plasma gasification $\quad$ C-3

$\begin{array}{ll}\text { Molten salt oxidation } & \text { F-1 }\end{array}$

Molten metal waste destruction $\quad$ G-1

$\begin{array}{ll}\text { Steam gasification } & \text { H-1 }\end{array}$

Joule-heated vitrification $\quad \mathrm{J}-1$

Thermal desorption and mediated electrochemical oxidation $\quad$ K-1

Thermal desorption and supercritical water oxidation $\quad$ L-1

\section{Addendum}


Table 1-2. Systems included in the Integrated Nonthermal Treatment System Study.

System Description

Designation

Low temperature vacuum thermal desorption with mediated electrochemical

NT-1

oxidation and debris grouting

Low temperature vacuum thermal desorption with catalyzed wet oxidation

NT-2

Washing with mediated electrochemical oxidation

NT-3

Low temperature vacuum thermal desorption and washing with acid digestion

NT-4

Low temperature vacuum thermal desorption and washing with catalyzed wet

NT-5 oxidation

The ITTS and INTS studies provide an objective evaluation of thermal and nonthermal treatment systems using various technologies for organic destruction, contaminant separation, and waste stabilization. System effluents and life-cycle costs were determined, and research and development needs were identified. However, some thermal and all nonthermal systems are very immature and the capabilities assumed for the purposes of developing conceptual system designs and mass balances have not been proven or demonstrated. This early evaluation of immature technologies has helped to identify R\&D needs, deficiencies in knowledge required for implementation, and some of the issues associated with highly optimistic system and technology performance assessments. The evaluation does not imply that these technologies are ready for deployment or that they can actually perform as assumed in these studies.

The INTS study had stakeholder and Native American participation throughout the systems evaluation process via the Tribal and Stakeholder Working Group (TSWG). The TSWG assisted in determining the scope of the INTS study and identified issues of concern when treating mixed waste. These concerns are expressed in a set of principles, known as the "Tribal and Stakeholder Principles," that are described in detail in Reference 4 and that can be applied to the evaluation of treatment systems and technologies. In addition to the principles, several other issues were identified by the TSWG. The principles and issues that can be quantified and that lend themselves to comparison among systems are listed in Table 1-3.

An Independent Peer Review Panel (IPRP) and a Users Panel reviewed the reports and were briefed on the results of these studies by the principal investigators. The IPRP provided valuable comments and recommendations regarding these and future studies, and recommendations for future research and development.

This report compares the salient features of several representative thermal systems from the ITTS study and all the nonthermal systems in the INTS study. Major differences between systems are discussed, as are the reasons for these differences, and the advantages and disadvantages of each system are identified. 
Table 1-3. Tribal and stakeholder principles and issues of concern.

\begin{tabular}{|c|c|}
\hline Principle & Subprinciple $^{\mathrm{a}}$ \\
\hline Minimize effluent & $\begin{array}{l}\text { Minimize effluents that have the potential to } \\
\text { carry hazardous materials or substances capable } \\
\text { of causing environmental consequences (3.2) }\end{array}$ \\
\hline $\begin{array}{l}\text { Minimize effects on human health and the } \\
\text { environment, including worker health and safety }\end{array}$ & $\begin{array}{l}\text { Minimize exposure now }(3.2,3.4,3.5,3.6) \\
\text { Minimize exposure in the future }(3.2 .3,3.3) \\
\text { Minimize the potential for release of hazardous } \\
\text { and radioactive materials from final disposal } \\
\text { and storage products ( } 3.3) \\
\text { Minimize the potential for accidents within the } \\
\text { system (4.0) }\end{array}$ \\
\hline Minimize waste generation & $\begin{array}{l}\text { Minimize creation of new hazardous materials } \\
\text { by treatment ( } 3.7 .2 \text { ) } \\
\text { Minimize the volume of waste sent to final } \\
\text { disposal and storage (3.2.3) }\end{array}$ \\
\hline $\begin{array}{l}\text { Address social cultural, and spiritual } \\
\text { considerations }\end{array}$ & $\begin{array}{l}\text { Minimize land use for disposal and storage ( } 3.1) \\
\text { Waste should be stored in a retrievable manner } \\
\text { (4.0) } \\
\text { Stable waste forms for long term storage or } \\
\text { disposal ( } 3.3 \text { ) } \\
\text { Reflect special site considerations }(3.8) \\
\text { Reflect cultural values }(3.1,3.2,3.7,3.8)\end{array}$ \\
\hline $\begin{array}{l}\text { Provide adequate and understandable } \\
\text { information }\end{array}$ & $\begin{array}{l}\text { Criteria for evaluating systems should be } \\
\text { flexibly applied ( } 4.0) \\
\text { Provide better information on health and safety } \\
\text { (4.0) } \\
\text { Provide better information on performance ( } 3.4 \text {, } \\
3.11) \\
\text { Focus on existing stored waste, add projected } \\
\text { impact of future waste generation ( } 4.0) \\
\text { Communicate when systems of technologies } \\
\text { could be available (3.11) }\end{array}$ \\
\hline $\begin{array}{l}\text { Incorporate Tribal and Stakeholder involvement } \\
\text { with DOE procurement }\end{array}$ & $\begin{array}{l}\text { This is a policy issue that cannot be addressed } \\
\text { in these technical studies }\end{array}$ \\
\hline
\end{tabular}

a. Section of this report in which concern is discussed is given in parentheses 


\subsection{Report Organization}

This report is organized into four sections plus the references. Section 1 provides the background to the ITTS and INTS studies and to this comparison report. The differences in how the waste is distributed between treatment processes is discussed, and the reasons for selecting the ITTS systems for comparison are identified. A summary of the characteristics compared in this report is provided.

Section 2 provides a brief description of the systems compared in this report, and the distribution of the waste among the subsystems for each system. In Section 3 the system characteristics are compared and the reasons for differences discussed. Section 4 contains a summary of the comparison and conclusions that may be drawn from this comparison of thermal and nonthermal systems.

\subsection{Waste Profiles}

In the ITTS and INTS studies, treatment systems are required to process $2927 \mathrm{lbs} / \mathrm{hr}$ of contact handled, mixed low-level waste. The profile for the waste input to these systems is shown in Table 1-4. Because nonthermal technologies are not as omnivorous as thermal technologies, waste streams that can be combined and treated in a single primary thermal treatment unit (e.g., rotary kiln, plasma furnace) must be separated and routed to various nonthermal treatment processes. For example, the $2000 \mathrm{lbs} / \mathrm{hr}$ of combustible and noncombustible waste that was treated in a primary thermal treatment unit is distributed to several nonthermal treatment subsystems as shown in Table 1-5. This waste stream consists of 328.5 $\mathrm{lbs} / \mathrm{hr}$ of soil, $1007.2 \mathrm{lbs} / \mathrm{hr}$ of process residue, $574.4 \mathrm{lbs} / \mathrm{hr}$ of combustible liquids and soft debris, and other components. Because organically-contaminated aqueous waste can be treated in the aqueous-based chemical oxidation processes in the nonthermal systems, the $80 \mathrm{lbs} / \mathrm{hr}$ of aqueous waste that went to aqueous waste treatment in the thermal systems is now separated in the front-end handling subsystem into two streams: $60.8 \mathrm{lbs} / \mathrm{hr}$ of aqueous waste with no identifiable organic content, and $19.2 \mathrm{lbs} / \mathrm{hr}$ of organically-contaminated aqueous waste that can be treated in the chemical oxidation processes.

The $50 \mathrm{lbs} / \mathrm{hr}$ of mercury contaminated waste consists of $3 \mathrm{lbs} / \mathrm{hr}$ of elemental mercury and $47 \mathrm{lbs} / \mathrm{hr}$ of solid waste that, in thermal systems, was retorted and the mercury vaporized, condensed, and amalgamated. In nonthermal systems, the $47 \mathrm{lbs} / \mathrm{hr}$ of solid waste contaminated with mercury is categorized as soft or complex debris, which is either treated by low-temperature vacuum thermal desorption (at a lower temperature than retorting) followed by mercury leaching, washed, or, in the case of soft debris, treated in an oxidizing acid bath. The mercury compounds are subsequently precipitated and stabilized in polymer.

For the INTS study, soft debris consists primarily of combustible debris items such as rags, paper, and plastics. This category also includes some metal turnings and mercury-contaminated waste. Open debris has accessible surface contamination that can be removed by thermal desorption, washing, or abrasive blasting. Any metal that can be decontaminated falls into this category, as does concrete, bricks, etc. Complex debris either has no organic contaminants and does not warrant decontamination (e.g., firebrick), or has internal contamination that cannot be accessed for removal. The major portion (148.5 $\mathrm{lbs} / \mathrm{hr}$ ) of complex debris is metals that are internally contaminated (pumps, valves, pipe, motors, etc.). 
Table 1-4. Total system input for thermal and nonthermal systems.

\begin{tabular}{|c|c|c|c|}
\hline \multicolumn{2}{|c|}{ Thermal System Input } & \multicolumn{2}{|c|}{ Nonthermal System Input } \\
\hline Type of Waste & $\begin{array}{l}\text { Mass Feed Rate } \\
\quad(\mathrm{lbs} / \mathrm{hr})\end{array}$ & Type of Waste & $\begin{array}{l}\text { Mass Feed Rate } \\
(\mathrm{lbs} / \mathrm{hr})\end{array}$ \\
\hline $\begin{array}{l}\text { Combustible Organic } \\
\text { Liquids, Sludge, and } \\
\text { Soft Debris }\end{array}$ & 660 & $\begin{array}{l}\text { Organic Liquid and } \\
\text { Sludge Waste }\end{array}$ & 185 \\
\hline \multirow{4}{*}{$\begin{array}{l}\text { Noncombustible Solids } \\
\text { (process residue, soil. } \\
\text { and open debris) }\end{array}$} & 1340 & $\begin{array}{l}\text { Process Residue \& } \\
\text { Inorganic Sludge }\end{array}$ & 1007 \\
\hline & & Bulk Soil & 329 \\
\hline & & $\begin{array}{l}\text { Soft (combustible) } \\
\text { Debris }\end{array}$ & 435 \\
\hline & & Open Nonmetal Debris & 80 \\
\hline $\begin{array}{l}\text { Metal with Fixed or } \\
\text { Internal Contamination }\end{array}$ & 149 & $\begin{array}{c}\text { Complex Debris } \\
\text { (internally contaminated } \\
\text { metal, firebrick, etc.) }\end{array}$ & 177 \\
\hline $\begin{array}{l}\text { Open Metal Debris with } \\
\text { Surface Contamination }\end{array}$ & 468 & $\begin{array}{l}\text { Open Metal Debris with } \\
\text { Surface Contamination }\end{array}$ & 462 \\
\hline Lead & 26 & Lead & 26 \\
\hline Aqueous Waste & 80 & Aqueous Waste & 61 \\
\hline $\begin{array}{l}\text { Mercury Contaminated } \\
\text { Waste }\end{array}$ & 50 & $\begin{array}{l}\text { Mercury Contaminated } \\
\text { Waste }\end{array}$ & $50^{\mathrm{a}}$ \\
\hline Special Waste & 153 & Special Waste & 155 \\
\hline Sulfide and Halide Salts & 1 & Sulfide and Halide Salts & 7 \\
\hline Empty Drums & b & Empty Drums & b \\
\hline Empty Bins & c & Empty Bins & c \\
\hline Total & 2927 & Total & 2927 \\
\hline \multicolumn{4}{|c|}{$\begin{array}{l}\text { a. Includes } 3 \mathrm{lbs} / \mathrm{hr} \text { of metallic mercury, } 22 \mathrm{lbs} / \mathrm{hr} \text { of soft debris, and } 25 \mathrm{lbs} / \mathrm{hr} \text { of complex debris } \\
\text { b. It is assumed that } 50 \% \text { of the drums are surface contaminated and can be decontaminated and } \\
\text { recycled. The other } 50 \% \text { are internally contaminated and are treated as complex debris in } \\
\text { nonthermal systems and sent to a metal melter in thermal systems. }\end{array}$} \\
\hline \multicolumn{4}{|c|}{$\begin{array}{l}\text { c. It is assumed that all bins are fiber-reinforced plastic and are classified as soft debris in } \\
\text { nonthermal systems or combustible solids in thermal systems. }\end{array}$} \\
\hline
\end{tabular}


Table 1-5. Redistribution of ITTS throughput into INTS subsystems.

\begin{tabular}{|c|c|c|c|c|c|c|c|c|c|c|c|c|c|}
\hline \multirow[b]{2}{*}{$\begin{array}{c}\text { ITTS } \\
\text { Subsystems }\end{array}$} & \multirow[b]{2}{*}{$\begin{array}{l}\text { ITTS } \\
\text { Throughput } \\
\text { (lbs/hr) }\end{array}$} & \multicolumn{12}{|c|}{ Redistribution of ITTS Throughput into INTS Subsystems } \\
\hline & & $\begin{array}{c}\text { Organic } \\
\text { Destruction } \\
\text { Subsystem } \\
\text { (bs/hr) }\end{array}$ & $\begin{array}{l}\text { Process } \\
\text { Residue } \\
\text { Treatment } \\
\text { (bs/hr) }\end{array}$ & $\begin{array}{c}\text { Soil } \\
\text { Treatment } \\
\text { (lbs/hr) }\end{array}$ & $\begin{array}{l}\text { Soft Debris } \\
\text { Treatment } \\
\text { (lbs/hr) }\end{array}$ & $\begin{array}{c}\text { Open Debris } \\
\text { Treatment } \\
\text { (lbs/hr) }\end{array}$ & $\begin{array}{l}\text { Complex } \\
\text { Debris } \\
\text { Treatment } \\
\text { (lbshr) }\end{array}$ & $\begin{array}{c}\text { Special Waste } \\
\text { Treatment } \\
\text { (lbs/hr) }\end{array}$ & $\begin{array}{c}\text { Aqueous } \\
\text { Waste } \\
\text { Treatment } \\
\text { (lbshr) } \\
\end{array}$ & $\begin{array}{c}\text { Lead } \\
\text { Recovery } \\
\text { (lbs/hr) }\end{array}$ & $\begin{array}{l}\text { Mercury } \\
\text { Amalgam } \\
\text { (lbs/hr) }\end{array}$ & $\begin{array}{l}\text { Polymer } \\
\text { Stabilize } \\
\text { (lbshr) }\end{array}$ & $\begin{array}{l}\text { Metal Decon } \\
\text { (lbs/hr) [From } \\
\text { Open Debris] }\end{array}$ \\
\hline $\begin{array}{l}\text { Metal } \\
\text { Decon. }\end{array}$ & 468 & & & & 4.3 & 462.1 & & $1.6(\mathrm{Ba})$ & & & & & 462.1 \\
\hline $\begin{array}{l}\text { Metal } \\
\text { Melting }\end{array}$ & 149 & & & & 0.2 & & 148.5 & $0.3(\mathrm{Cd})$ & & & & & \\
\hline $\begin{array}{l}\text { Lead } \\
\text { Recovery }\end{array}$ & 26 & & & & & & & & & 26 & & & \\
\hline $\begin{array}{l}\text { Primary } \\
\text { Thermal } \\
\text { Treatment }\end{array}$ & 2000 & 166.2 & 1007.2 & 328.5 & 408.2 & 80.4 & 3.9 & & & & & 5.6 & \\
\hline $\begin{array}{l}\text { Aqueous } \\
\text { Waste } \\
\text { Treatment }\end{array}$ & 80 & 19.2 & & & & & & & 60.8 & & & & \\
\hline $\begin{array}{l}\text { Special } \\
\text { Waste } \\
\text { Treatment }\end{array}$ & 153 & & & & & & & 153 & & & & & \\
\hline $\begin{array}{l}\text { Mercury } \\
\text { Amalgam }\end{array}$ & 50 & & & & 22 & & 25 & & & & 3 & & \\
\hline $\begin{array}{l}\text { Polymer } \\
\text { Stabilize }\end{array}$ & 1 & & & & & & & & & & & 1 & \\
\hline Total & 2927 & 185.4 & 1007.2 & 328.5 & 434.7 & 542.5 & 177.4 & 154.9 & 60.8 & 26 & 3 & 6.6 & - \\
\hline $\begin{array}{l}\text { Percent of } \\
\text { INTS Total } \\
\text { Input }\end{array}$ & $100 \%$ & $6.3 \%$ & $34.4 \%$ & $11.2 \%$ & $14.9 \%$ & $18.5 \%$ & $6.1 \%$ & $5.3 \%$ & $2.1 \%$ & $0.9 \%$ & $0.1 \%$ & $0.3 \%$ & - \\
\hline
\end{tabular}




\subsection{System Selection}

Seven thermal systems, selected as representative of the twenty in the ITTS study, were used for the comparison study presented in this report. Four of these systems use relatively mature technologies (Systems A-1, A-2, A-7, and A-8), whereas three systems are comprised of innovative technologies (Systems C-1, G-1, and H-1). The seven systems are listed below with the reasons for their selection.

System A-1 A rotary kiln system that represents the typical incinerator using vitrification for waste stabilization of the ash residue.

System A-2 Same as System A-1, but with oxygen for combustion gas in place of air to compare the effluent from a minimum offgas thermal system with the effluent from nonthermal systems.

System A-7 Slagging rotary kiln, which stabilizes waste directly in a slag, thereby eliminating the vitrifier. Internally-contaminated metal is also treated in the kiln, eliminating the metal melter as well as the possibility of recovering and recycling internally-contaminated metals. Although this is a simpler system, more waste goes to disposal.

System A-8 Same as System A-1, but grout is used to stabilize ash in place of the vitrifier. This allows comparison of a thermal system with nonthermal stabilization to the nonthermal systems that are precluded from using thermal stabilization technologies.

System C-1 Similar to System A-7 except that a plasma furnace is used in place of the kiln. Thus, the vitrifier and metal melter are eliminated but an innovative and unproven thermal technology is used. The developers claim that the metal can be separated from the slag and is recyclable.

System G-1 This new molten metal technology eliminates the need for a vitrifier and metal decontamination. All combustible and noncombustible waste, and all metals (except lead and mercury), are reported to be treatable in a single metal melter, thereby eliminating several ancillary operations. The metal melter is operated in a reducing environment to produce a syngas that is combusted in a catalytic oxidizer so the air pollution control (APC) system is small.

System H-1 In this new technology, combustible and noncombustible waste must be separated as in nonthermal systems. Combustible material is treated in a steam gasifier in a reducing (or oxygen limited) mode to produce a combustible syngas that is oxidized in a thermal oxidizer. Noncombustible wastes are treated directly in a vitrifier capable of treating organically-contaminated solids. 


\section{SYSTEM DESCRIPTIONS AND WASTE DISTRIBUTIONS}

In this section, the thermal and nonthermal systems being compared are briefly described and the distribution of the various waste streams through the subsystems is shown; details regarding system and technology descriptions, operation, and mass balances are provided in the references. Figures 2-1 through 2-12 are simplified flowsheets for the systems. For clarity, these figures show only the incoming waste streams and do not depict the routing of internal wastes or process chemicals. As shown in the figures, glass formers or soil are added to the main thermal treatment unit in those thermal systems that use vitrification for stabilization. These glass formers are added such that there is a 2:1 ratio of ash (bottom ash and flyash) to soil entering the vitrifier. The amount of soil added varies slightly between systems due to the variation in the amount of ash generated by the different operating characteristics of the main thermal treatment units.

\subsection{Thermal Systems}

Seven of the twenty thermal systems of the ITTS study were selected as representing a range of the most relevant technologies for comparison. These systems, identified in Section 1.4, use both relatively mature (Systems A-1, A-2, A-7, and A-8) and innovative technologies (Systems C-1, G-1, and H-1).

\section{System A-1: Rotary Kiln with Air}

A flowsheet showing the major components of this system and the percent of the waste treated in each component is given in Figure 2-1. This system uses a standard rotary kiln with air for combustion as the primary treatment unit. Combustible and noncombustible wastes (e.g., debris, soils, and sludges) are fed into the kiln with additional glass formers or soil. The resulting ash is converted to a stable final waste form in the vitrifier. Metals with entrained contamination and lead articles that cannot be decontaminated (lead gloves, aprons, etc.) are separated and melted in separate metal melters to produce ingots for recycle, and a slag that is sent to disposal. Bulk metals and lead with surface contamination are decontaminated with abrasive blasting that produces a clean metal for recycle. Mercury-contaminated waste is sent to a retort where the mercury is evaporated and then condensed and collected. This elemental mercury, along with the elemental mercury removed from the main waste stream in the sorting process, is amalgamated for disposal.

The main thermal treatment unit includes a secondary combustion chamber to oxidize any organics escaping from the kiln. The offgas is cooled in the APC by quenching. Baghouse filters followed by HEPA filters remove particulates from the offgas, the flyash is sent to the vitrifier for stabilization, charcoal filters remove particulates and trace organics and mercury, a scrubber is used to remove acid gases, and an abatement process removes $\mathrm{NO}_{\mathbf{x}}$.

The water treatment system treats wastewater entering from outside the facility as well as the water used in the facility such as quench and scrubber water and water used in decontamination processes. Treated water is recycled; however, in most cases more water is generated in the treatment processes than is required for system operation so that some water must be discharged. Heavy organics are removed by phase separation and sent to the main thermal treatment unit, and dissolved organics are destroyed in the aqueous phase with an ultraviolet (UV) photooxidation process. Inorganics are removed by precipitation and filtering. Trace organics are removed by activated carbon filters, and trace inorganics removed with ion exchange resins. The primary stabilization process is vitrification of treated nonmetallic waste. Secondary wastes, or salts, are stabilized in polymer. 


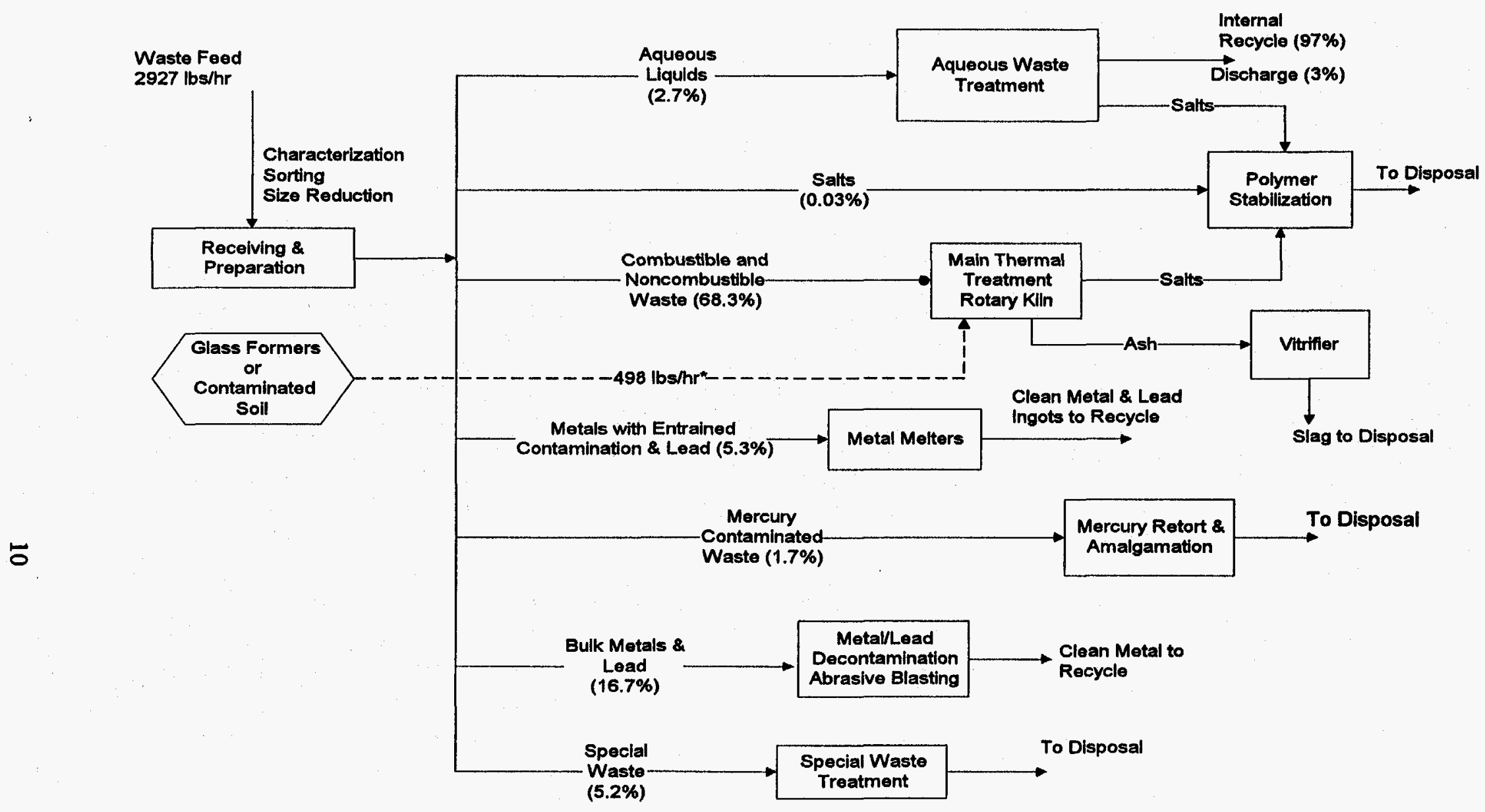

Note: Glass forming additives or contaminated soils are in addition to the waste input.

Figure 2-1. System A-1 - Rotary kiln with air 


\section{System A-2: Rotary Kiln with Oxygen}

A flowsheet showing the major components of this system and the percent of the waste treated in each component is given in Figure 2-2. This system is identical to System A-1 except that oxygen is used for combustion in place of air. This reduces the offgas from the rotary kiln by eliminating most of the nitrogen from the combustion gas. However, because rotary kilns operate at negative pressure there is an inflow of air into the kiln so that not all nitrogen is eliminated.

\section{System A-7: Slagging Rotary Kiln}

A flowsheet showing the major components of this system and the percent of the waste treated in each component is given in Figure 2-3. This system is essentially identical with System A-1; however, metals with entrained contamination (except lead) are fed to the kiln with the combustible and noncombustible wastes. The kiln is operated at a higher temperature than a standard rotary kiln to produce a glassy slag that can be disposed of directly, thereby eliminating the need for a vitrifier. Flyash from the APC system is returned to the kiln for immobilization in the slag.

\section{System A-8: Rotary Kiln with Air and Grout Stabilization}

A flowsheet showing the major components of this system and the percent of the waste treated in each component is given in Figure 2-4. This system is identical to System A-1 except that the vitrifier is eliminated and the primary stabilization medium is grout. Thus, the ash from the kiln is stabilized in grout.

\section{System C-1: Plasma Furnace}

A flowsheet showing the major components of this system and the percent of the waste treated in each component is given in Figure 2-5. This system is identical to System A-7 except that the kiln is replaced with a plasma furnace. As with the slagging kiln, metal with entrained contamination is fed to the furnace with combustible and noncombustible wastes. However, the design of the furnace allows the metal to be separated from the slag and poured off to form ingots for recycling. The glassy slag can be disposed without further treatment. Flyash from the APC system is returned to the furnace for immobilization in the slag.

\section{System G-1: Molten Metal}

A flowsheet showing the major components of this system and the percent of the waste treated in each component is given in Figure 2-6. The main thermal treatment unit is the metal melter, which can treat combustible and noncombustible wastes as well as metal with entrained and surface contamination. The metal separates from the slag and can be poured off to form ingots for subsequent recycling. Lead with entrained contamination is treated in a separate metal melter, and surface-contaminated lead is decontaminated by abrasive blasting. The slag from the metal melter can be disposed without further treatment. Flyash from the APC system is returned to the melter for immobilization in the slag. The other subsystems are the same as in System A-1, but because little combustion air is used in the catalytic oxidizer the APC and aqueous waste treatment systems are much smaller. 


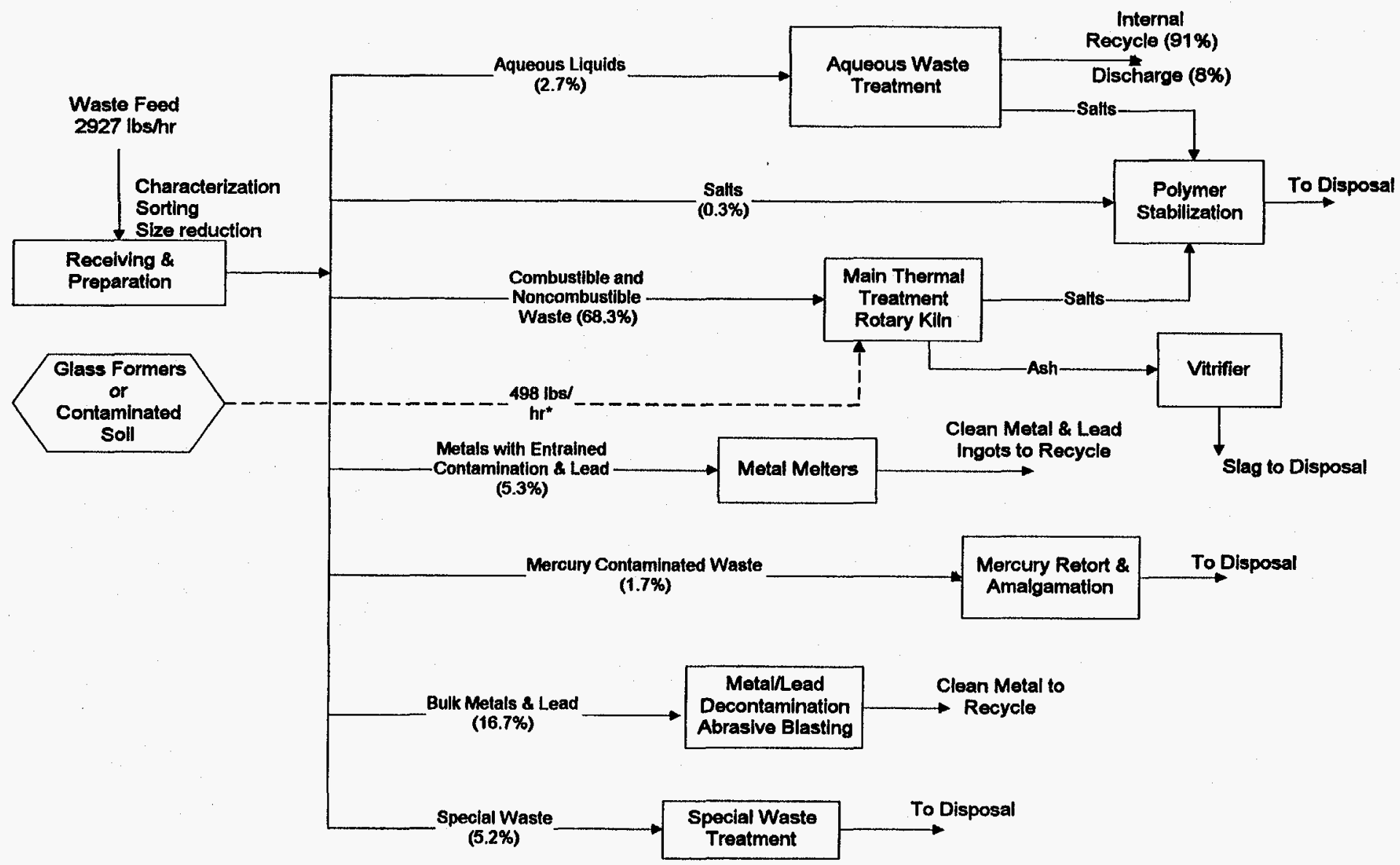

Note: Glass forming additives or contaminated solls are in addition to the waste input.

Figure 2-2. System A-2 - Rotary kiln with oxygen 


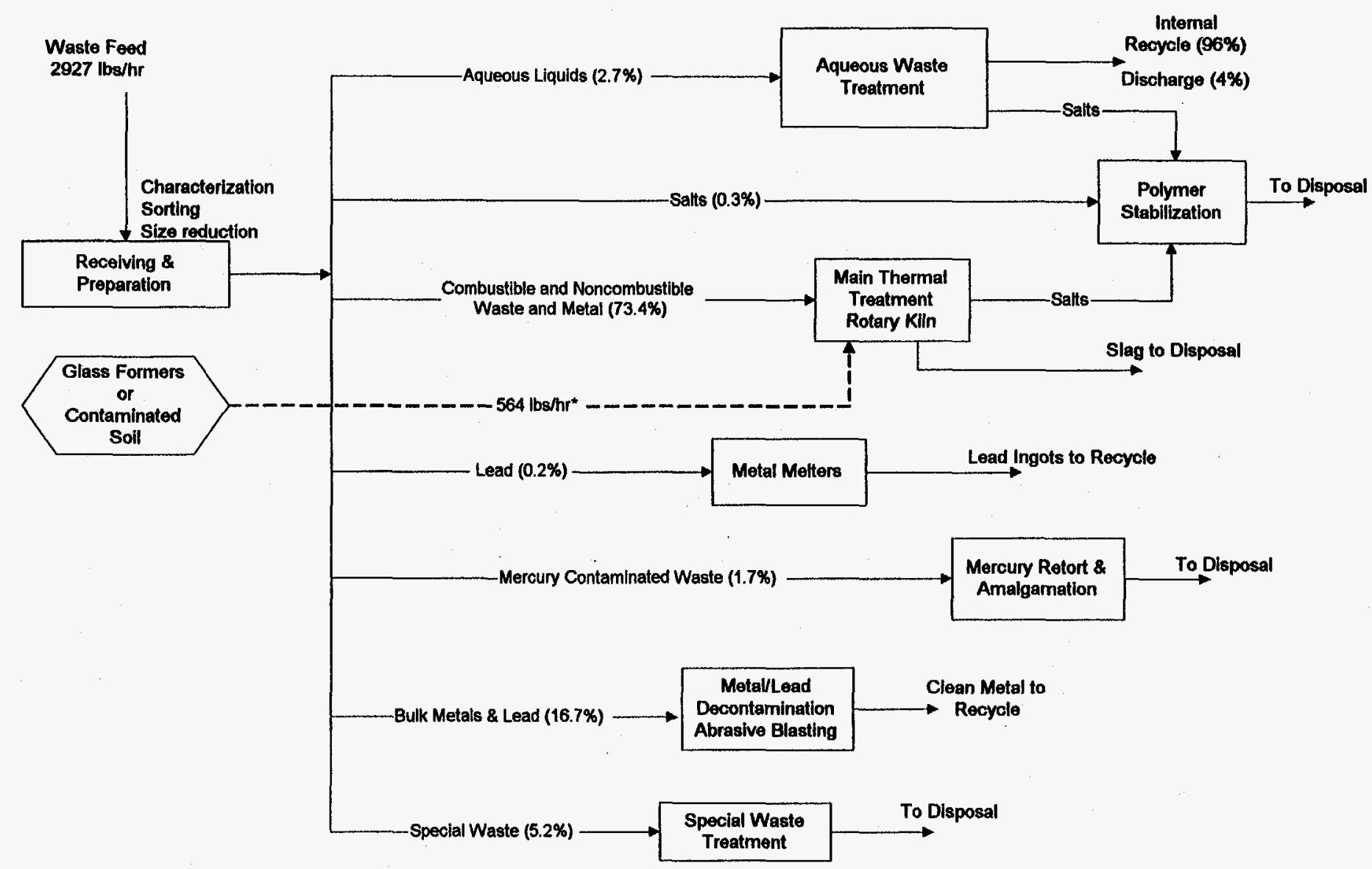

Note: Glass forming additives or contaminated solls are in addition to the waste input.

Figure 2-3. System A-7 - Rotary kiln with air 


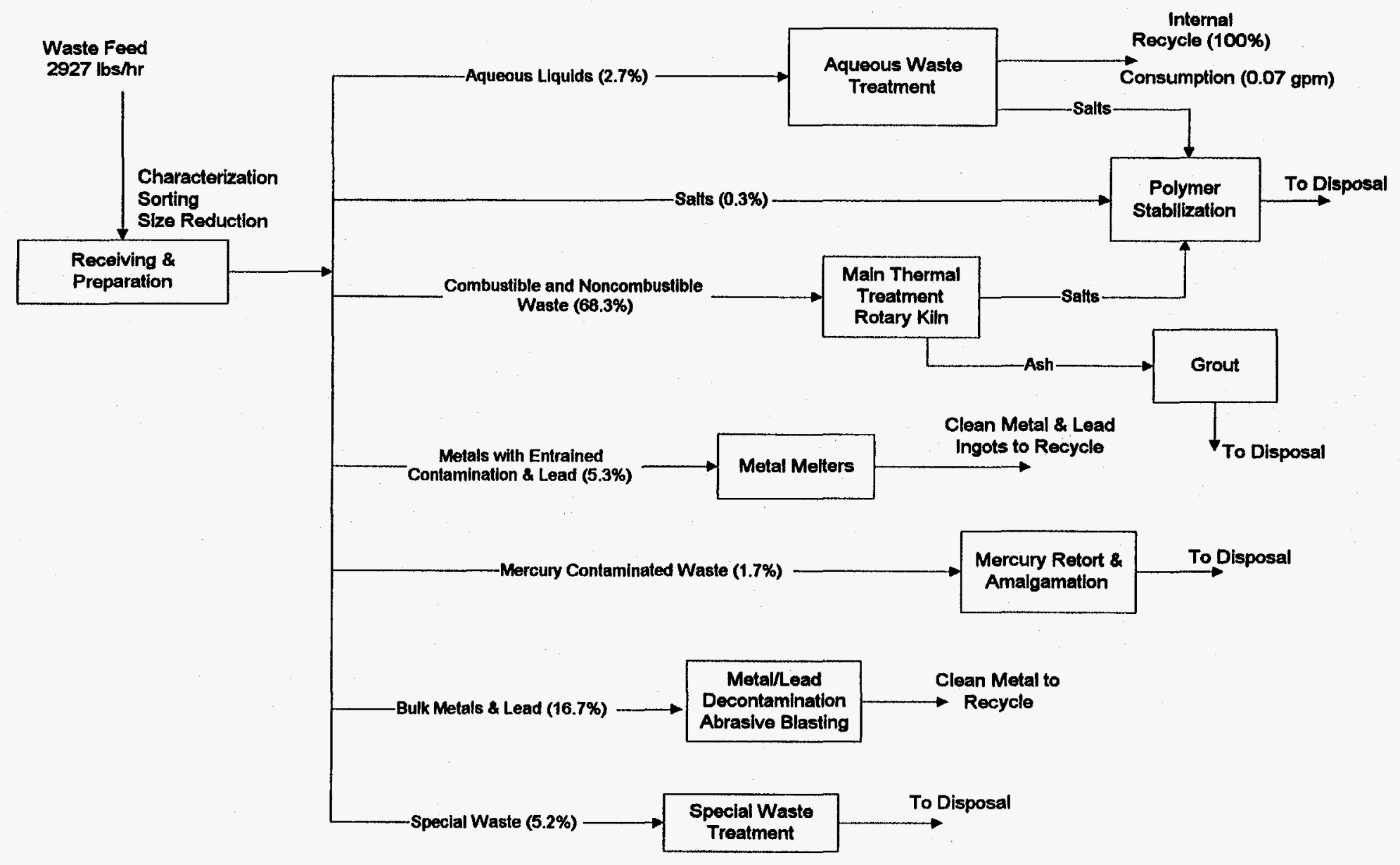

Figure 2-4. System A-8 - Rotary kiln with air and grout stabilization 


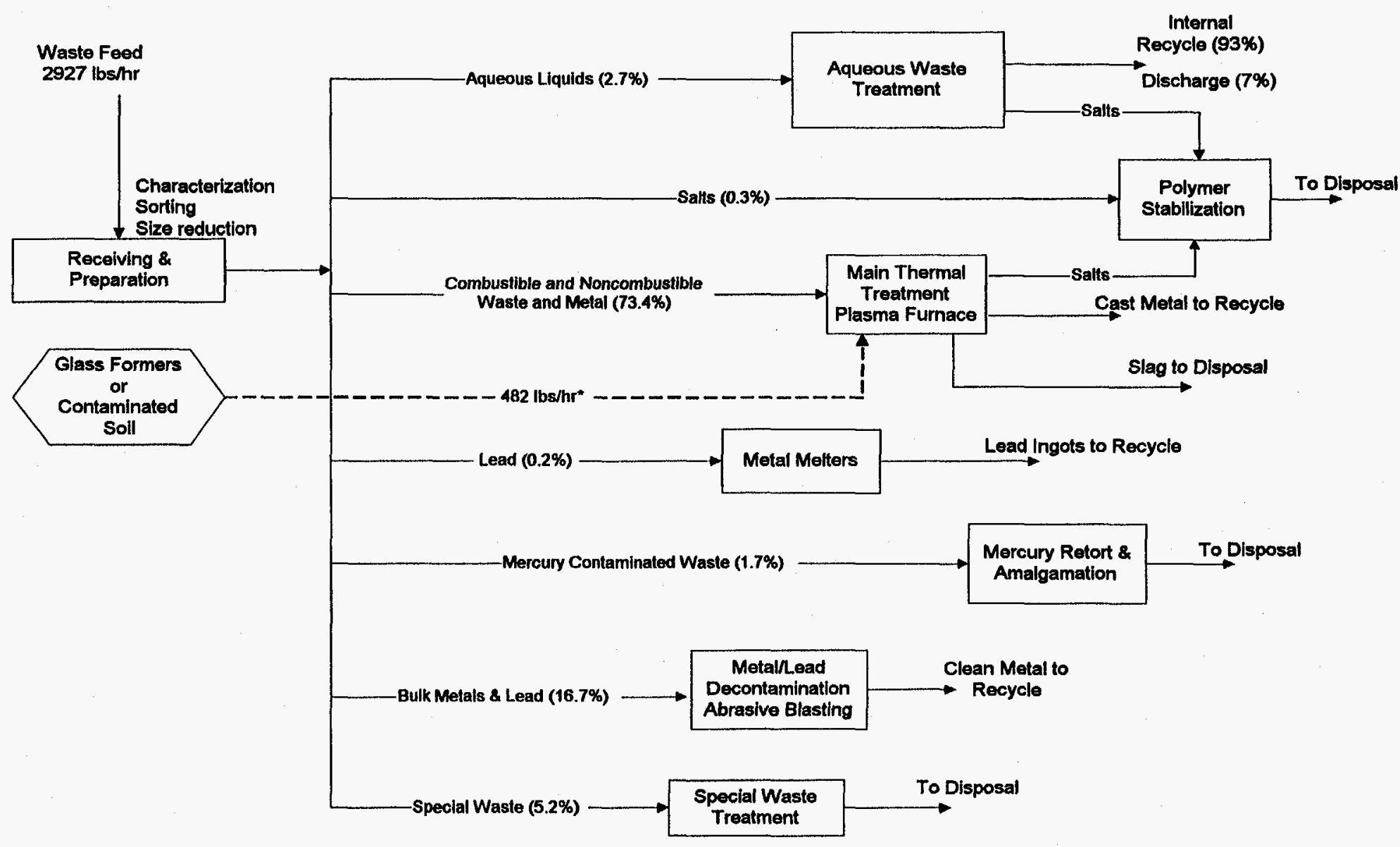

Note: Glass forming additives or contaminated soils are in addition to the waste input.

Figure 2-5. System C-1 - Plasma hearth furnace with air 


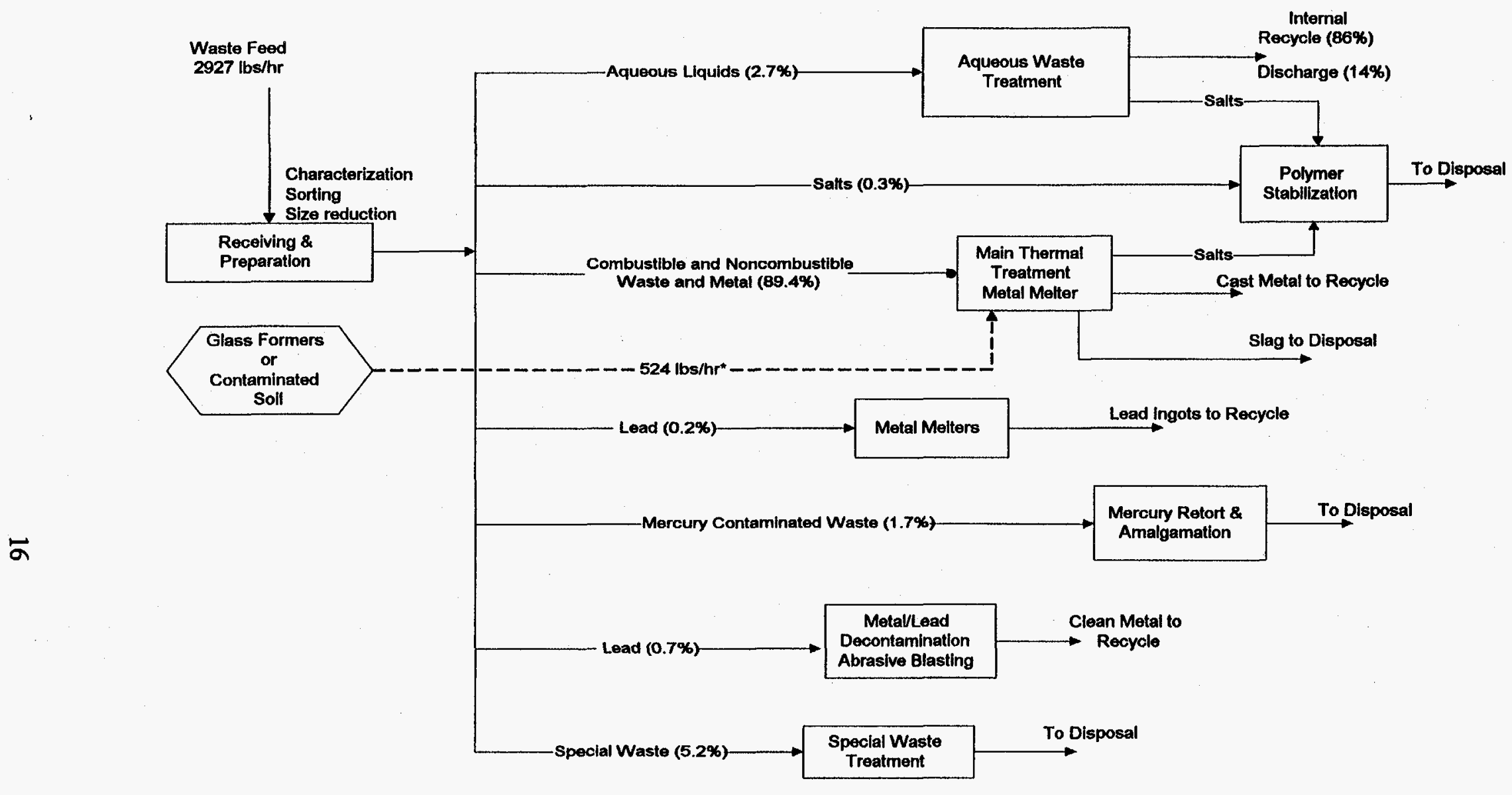

Note: Glass forming additives or contarninated soils are in addition to the waste input.

Figure 2-6. System G-1 - Molten metal 


\section{System H-1: Steam Gasification}

A flowsheet showing the major components of this system and the percent of the waste treated in each component is given in Figure 2-7. The main thermal treatment unit in this system is a steam gasifier that operates in a reducing mode to produce a combustible synthetic gas (syngas) that is oxidized in a thermal oxidizer. The gasifier can only treat combustible material. Nonmetallic noncombustible waste is separated and sent directly to a vitrifier. The vitrifier may be considered as part of the primary treatment subsystem since the organic contaminants on the noncombustible waste are destroyed in the vitrifier during the vitrification and stabilization process. The other waste streams are treated in the same manner as in System A-1.

\subsection{Nonthermal Systems}

Nonthermal technologies were selected, as described in Reference 4, for development of five nonthermal treatment systems. The five nonthermal systems all use innovative technologies that are immature relative to most thermal treatment processes. These technologies include chemical oxidation, low-temperature vacuum thermal desorption, and washing. In contrast to most of the thermal systems, in which the primary treatment process is a single thermal treatment unit, the primary treatment process of nonthermal systems consists of two or more processes in which organics are removed from the solid waste matrices and destroyed in a separate process. Nonthermal stabilization is used, i.e., grout, polymer, or phosphate-bonded ceramic. Details of the technologies used in these system designs are provided in Reference 4, as are system analyses.

\section{System NT-1: Grout Stabilization of Untreated Debris with Thermal Desorption and Mediated Electrochemical Oxidation}

A flowsheet showing the major components of this system and the percent of the waste treated in each component is given in Figure 2-8. The primary treatment process consists of low-temperature vacuum thermal desorption to remove organic contaminants from soils, process residues, and sludges, and a mediated electrochemical oxidation (MEO) process to treat the incoming organic liquids and sludges and the organic condensate from the thermal desorber. For inorganic waste matrices, the desorber may operate at pressures as low as $0.5 \mathrm{psia}$, and the waste may be heated to $350^{\circ} \mathrm{C}\left(660^{\circ} \mathrm{F}\right)$. All debris, and lead that cannot be decontaminated, is grouted for disposal without prior treatment. Grouting of debris without treatment is consistent with EPA's debris rule and simulates the treatment concept in several of DOE's site treatment plans.

As with the thermal systems, salts are stabilized in polymer, as are the treated process residues, and bulk metals and lead that have surface contamination are decontaminated by abrasive blasting. Metals with entrained contamination are grouted with the other debris. Mercury-contaminated waste presents a special problem without the use of a retort since metallic mercury is otherwise difficult to remove and stabilize. A discussion and comparison of mercury treatment and collection methods for thermal and nonthermal systems is provided in Section 3.5.

The nonthermal aqueous waste treatment subsystems are similar to those of the thermal systems but smaller since less water requires treatment. The nonthermal APC subsystems are also much smaller than the thermal APC subsystems. Because the temperature of the offgas from nonthermal processes is low, the quench process used in thermal systems is replaced with a condenser to separate water, organics, and mercury from the offgas stream. The secondary combustion chamber is replaced with a gas-phase corona 


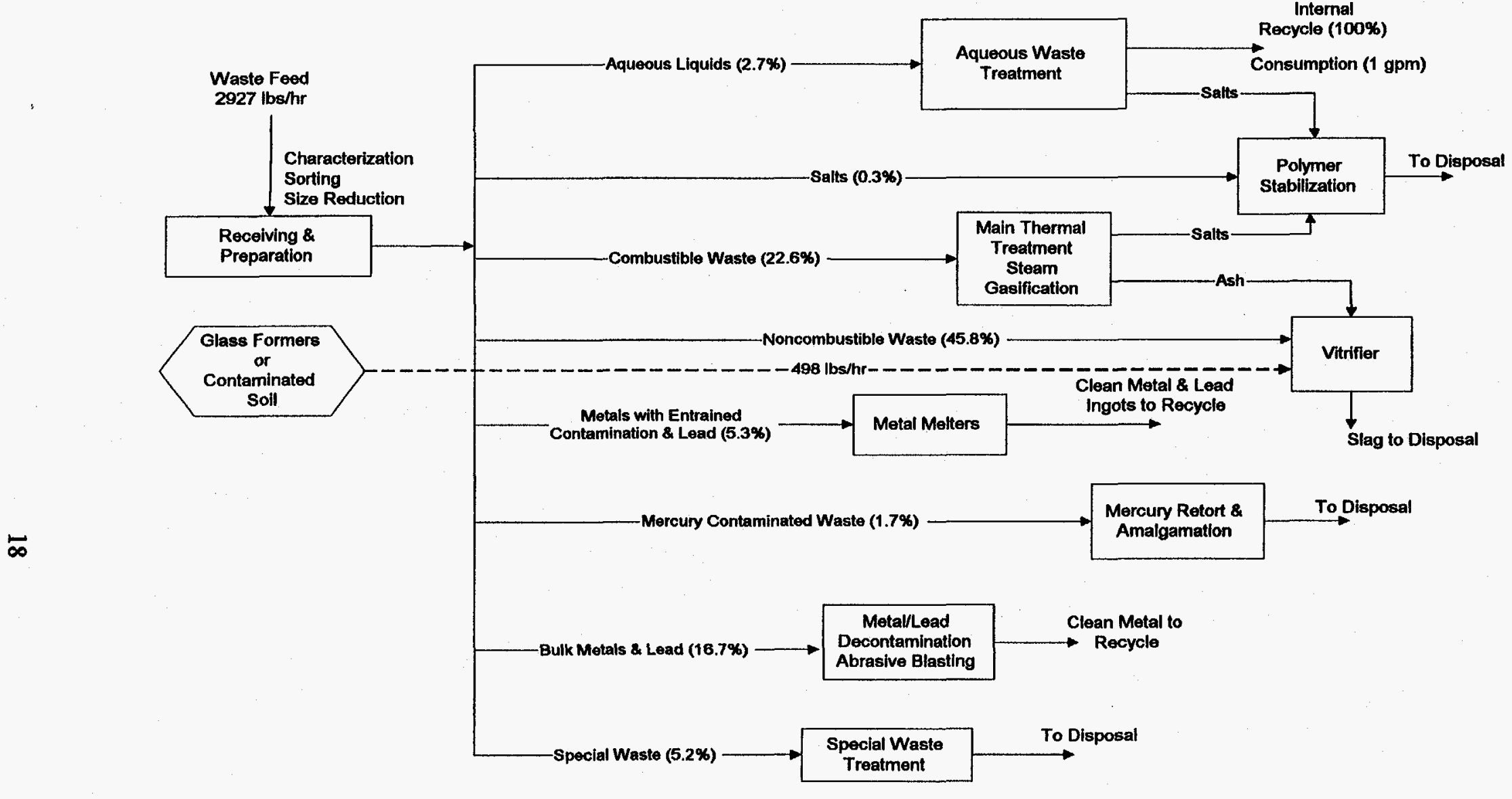

Note: Glass forming additives or contaminated soils are in addition to the waste input.

Figure 2-7. System H-1 - Steam gasification 


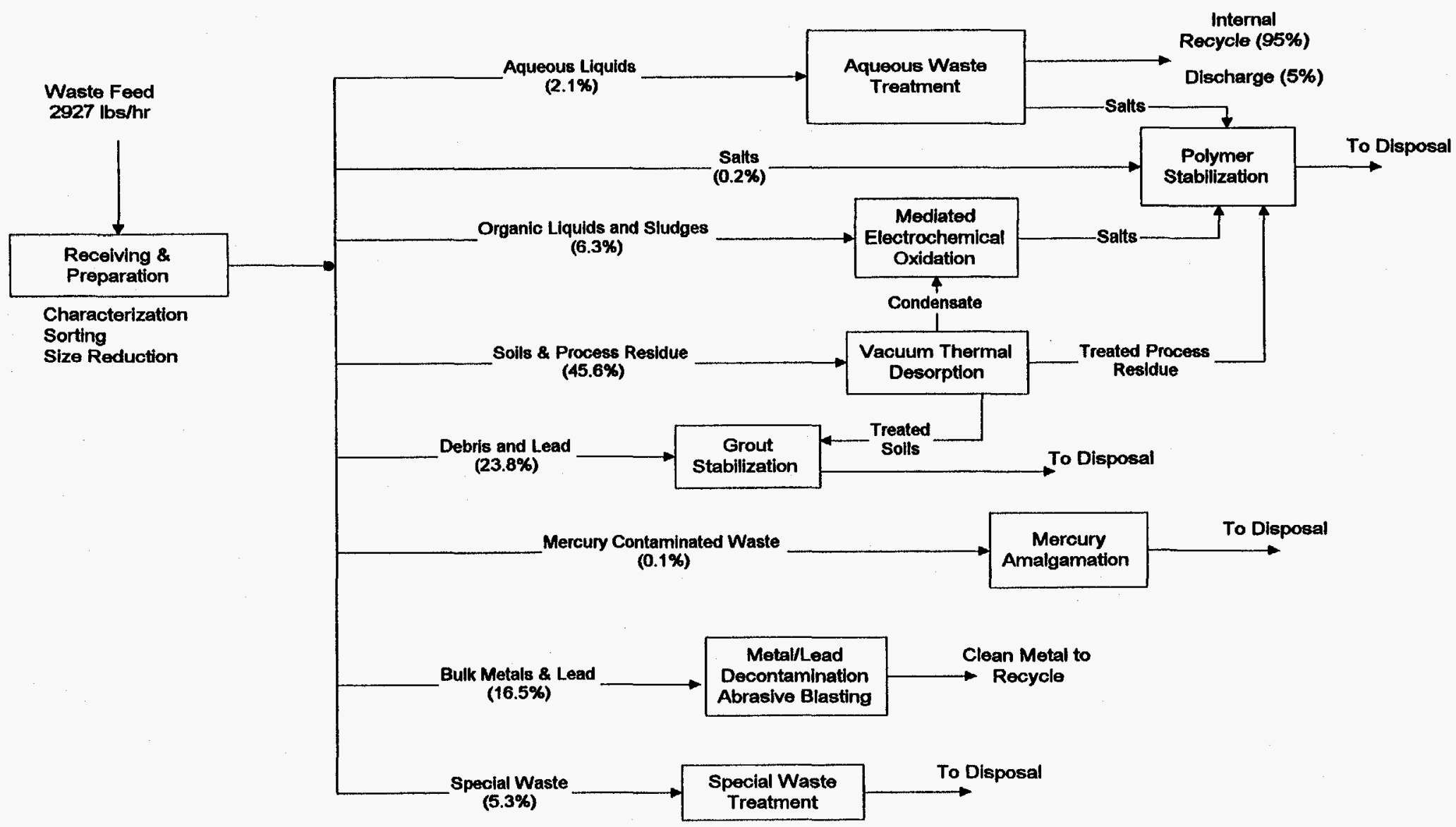

Figure 2-8. System NT-1 - Grout debris with vacuum thermal desorption and MEO 
reactor (GPCR) to oxidize the remaining trace amounts of volatile organics, and activated carbon filters are used for polishing the offgas stream before discharge. The remaining components are similar to the components in the thermal APC systems, including dry filters and HEPA filters for particulate collection, acid gas scrubbers, and sulfur-impregnated carbon for removal of trace levels of mercury.

\section{System NT-2: Enhanced Debris Treatment with Thermal Desorption and Catalyzed Wet Oxidation}

A flowsheet showing the major components of this system and the percent of the waste treated in each component is given in Figure 2-9. In this and the remaining nonthermal systems the debris is treated prior to stabilization. Organic contaminants are desorbed from soils, sludges, and debris in the lowtemperature vacuum thermal desorber. In this case, the desorber temperature may be limited to prevent melting of plastics in the soft debris waste stream. The desorber condensate and incoming organic liquids and sludges are destroyed in the catalyzed wet oxidation (CWO) process. Salts and treated process residues are stabilized in polymer; treated soils, debris, and lead articles that cannot be decontaminated are stabilized in grout. The remaining systems are the same as in System NT-1.

\section{System NT-3: Enhanced Debris Treatment with Washing and Mediated Electrochemical Oxidation}

A flowsheet showing the major components of this system and the percent of the waste treated in each component is given in Figure 2-10. The primary treatment train for this system consists of several washing processes and the MEO process. The washing processes use a variety of surfactants to remove organic contaminants from soils, process residues, sludges, and debris. The organic contaminants leave with the wash water stream, are separated from the water and surfactants in the aqueous waste treatment subsystem, and are destroyed, along with incoming organic liquids and sludges, in the MEO process.

A typical soil washing process, with various surfactants to solubilize organic contaminants, is used to treat soils and process residues. A gentle agitation wash is used to treat soft debris to prevent rags, paper, and plastics from sticking together and to allow access to all debris surfaces by the washing solution. Open and size-reduced complex debris undergo a high-pressure spray wash to remove contaminants. All other subsystems are the same as in System NT-1.

\section{System NT-4: Wash and Vacuum Thermal Desorption with Acid Digestion}

A flowsheet showing the major components of this system and the percent of the waste treated in each component is given in Figure 2-11. This system combines washing, thermal desorption, and acid digestion to treat the various waste streams. Organics are removed from process residues by thermal desorption, and soils and open debris are treated by aqueous soil washing and high-pressure spray washing processes, respectively. The separated organic contaminants are converted to carbon dioxide and water in an acid digestion process, along with the incoming organic liquids and sludges. Soft debris is also destroyed in an acid digestion process to decrease the volume of material requiring disposal.

The acid digestion process chosen for evaluation uses a mixture of nitric and phosphoric acids. Because of the potential synergism between the phosphoric acid process and the phosphate-bonded ceramic stabilization process, phosphate-bonded ceramics are used to stabilize treated process residue, soils, insoluble salts such as phosphates, and oxides. Soluble salts are stabilized in polymer. Treated debris and untreated complex debris are stabilized in grout. There is a high degree of uncertainty regarding the ability 


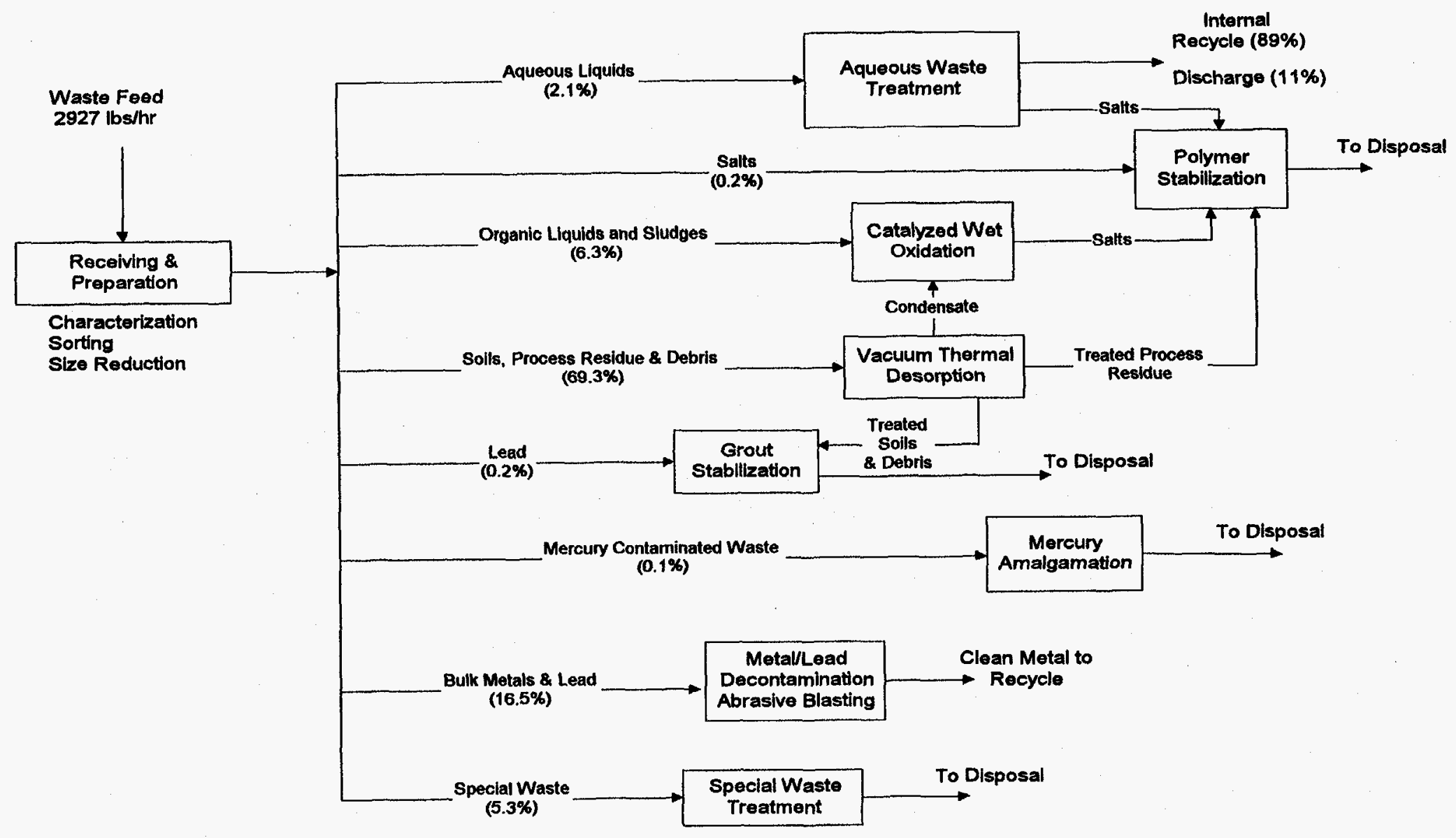

Figure 2-9. System NT-2 - Vacuum thermal desorption and CWO 


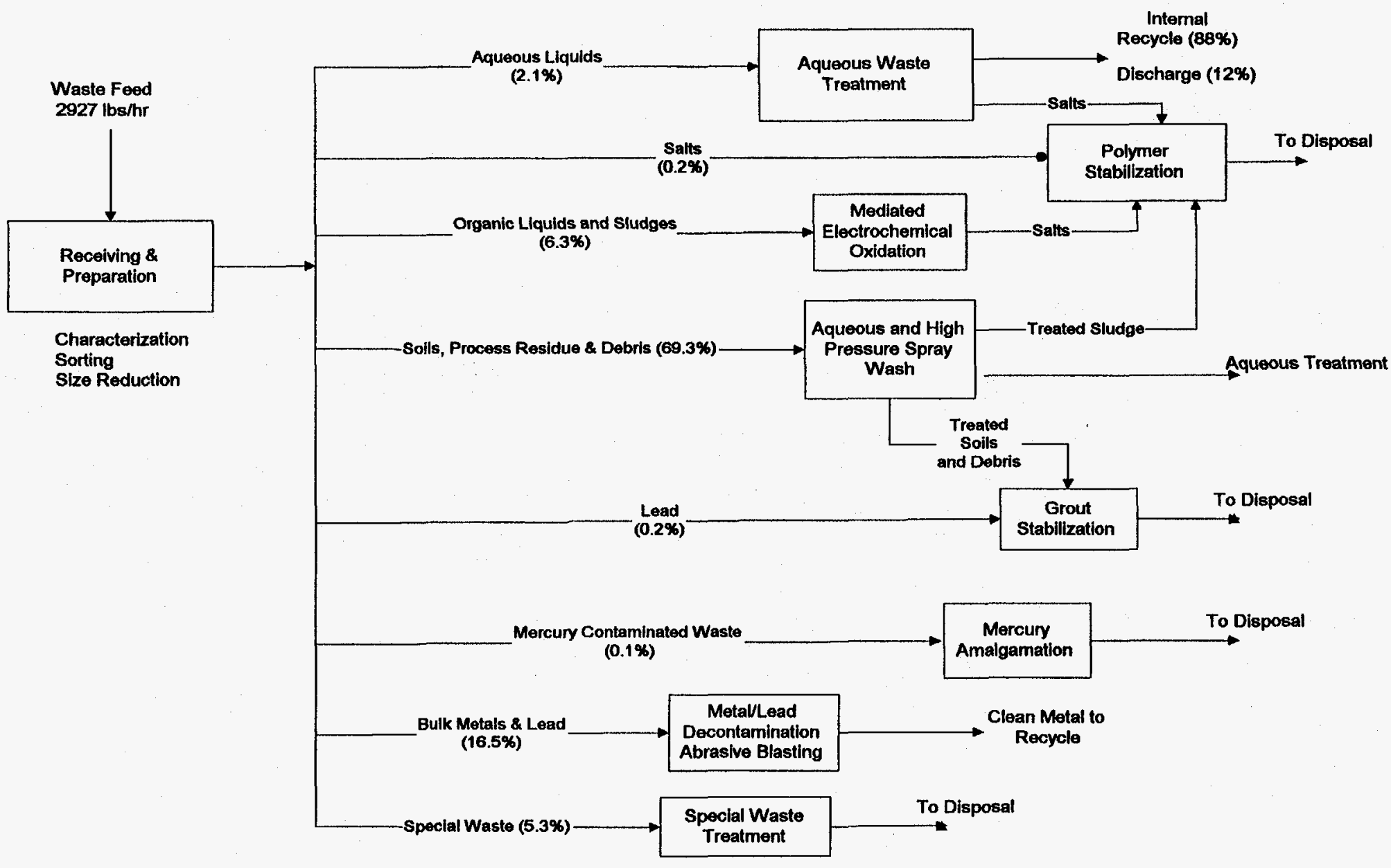

Figure 2-10. System NT-3 - Wash and MEO 


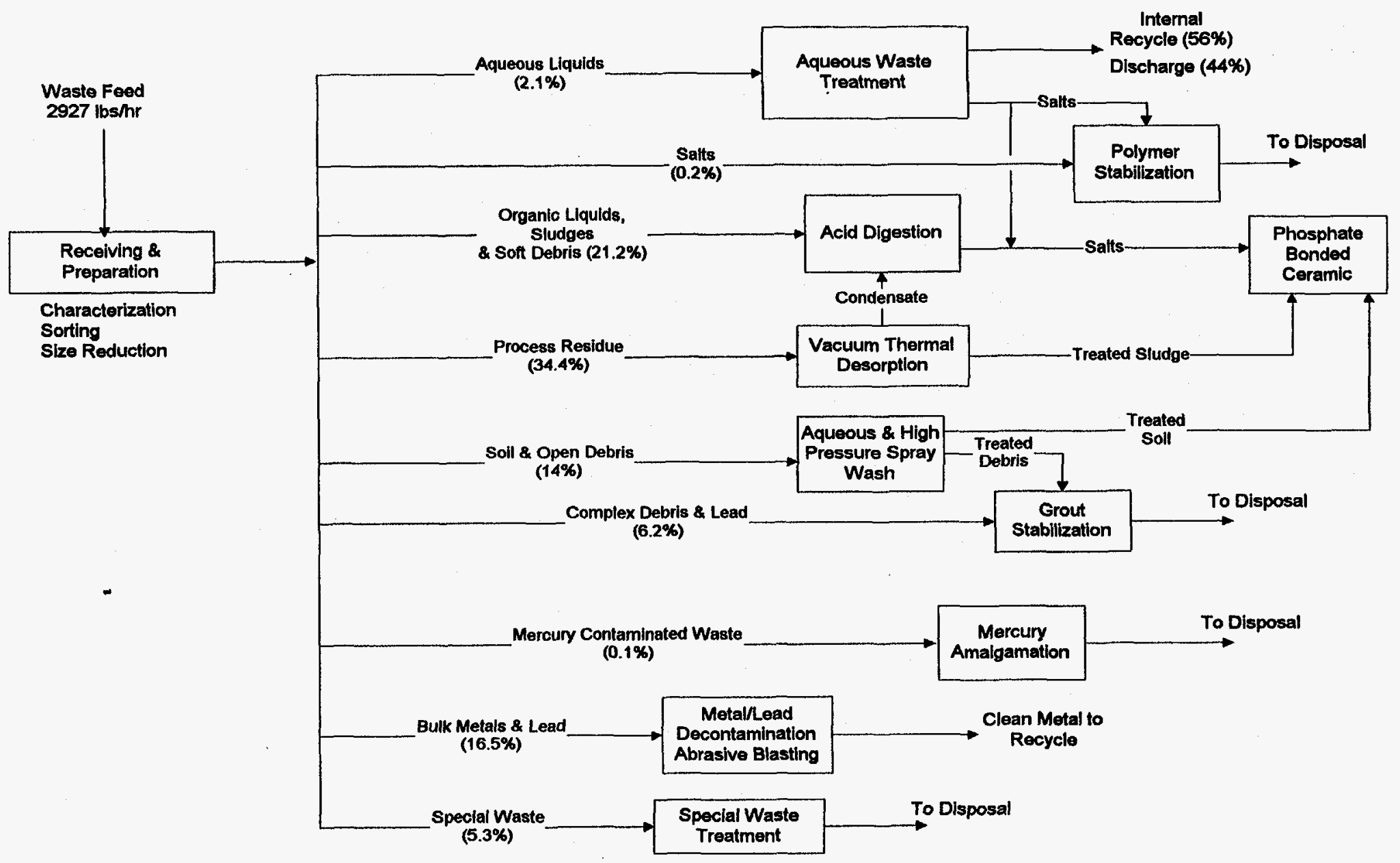

Figure 2-11. System NT-4 - Combined treatment with acid digestion 
to remove internal contamination from complex debris items, so application of the debris rule and direct stabilization appeared the most cost effective alternative. All other subsystems are the same as in System NT-1.

\section{System NT-5: Wash and Vacuum Thermal Desorption with Catalyzed Wet Oxidation}

This system is similar to System NT-4 except that the catalyzed wet oxidation process replaces acid digestion, and grout and polymer stabilization replace phosphate-bonded ceramic as shown in Figure 2-12.

\subsection{Summary of Waste Distributions}

A summary of the waste distribution through the various subsystems in each treatment system is shown in Table 2-1 for the thermal systems and Table 2-2 for the nonthermal systems. In this context, primary treatment is considered the process or processes required to destroy the organic contaminants in the waste. Most thermal systems have a single primary treatment process in which organics are destroyed, whereas nonthermal systems may have up to three unit operations involving separation and organic destruction that comprise primary treatment. In nonthermal systems, separation of organics from the solid inorganic matrices (soils, sludges, and debris) is necessary for efficient destruction of the organic contaminants and is considered part of the primary treatment process. Such separation by low-temperature vacuum desorption or washing is necessary to prevent the inorganic material from interfering with the organic destruction process. Except for System NT-1, in which all debris is grouted without treatment, $70 \%$ or more of the waste is distributed to the primary treatment process.

The waste types sent to the nonthermal primary treatment processes are very similar for all five systems. The major differences lie in the way metal wastes are handled. Complex debris, which includes metals with entrained contamination, is treated in the desorber in System NT-2 and in the washer in System NT-3. The waste input to the nonthermal primary treatment operations is nearly the same as the input to the main thermal treatment units of Systems A-7 and C-1 in which metals with entrained contamination are treated. Systems G-1 and NT-1 are anomalies: System G-1 treats all the non-lead metal with the rest of the waste in a metal melter, and System NT-1 does not treat any of the debris or metals in the primary treatment processes.

Because none of the nonthermal processes are as omnivorous as the main thermal treatment units, additional unit operations are required to treat the waste. More sorting and separation of waste streams, as well as characterization, is required in nonthermal systems. Much effort is expended in separation of organics from inert matrices such as soils, sludges, and debris in preparation for feeding the organic fraction to the organic destruction process. These additional processing requirements are reflected in higher personnel requirements and higher front-end handling costs as discussed later in this report. 


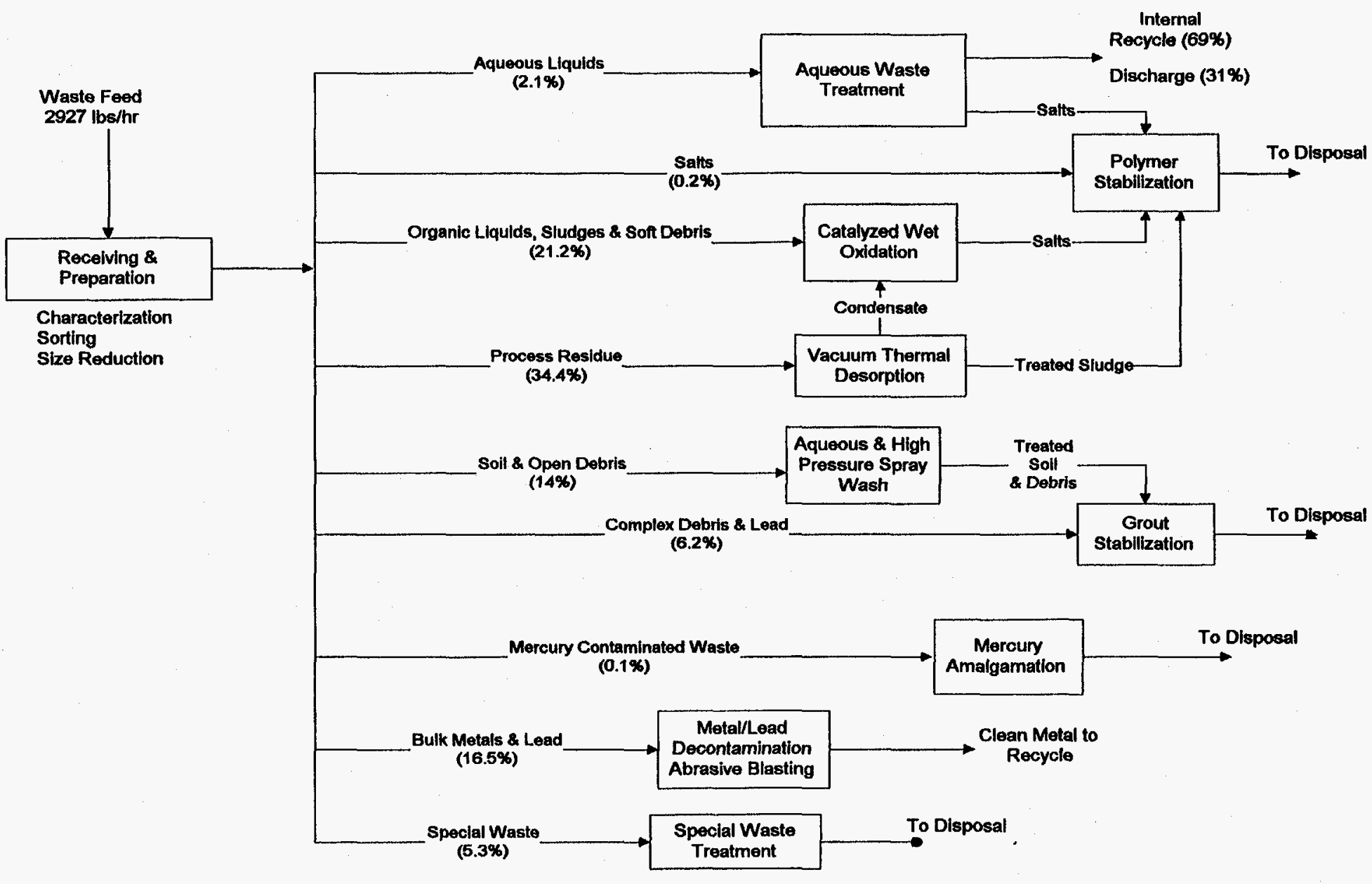

Figure 2-12. System NT-5 - Combined treatment with CWO 
Table 2-1. Percent of waste distributed to thermal treatment subsystem.

\begin{tabular}{|c|c|c|c|c|c|c|c|}
\hline Treatment Subsystem & $\begin{array}{c}\text { Rotary } \\
\text { Kiln/Air } \\
(\mathrm{A}-1)\end{array}$ & $\begin{array}{c}\text { Rotary } \\
\text { Kiln/ } \\
\text { Oxygen } \\
(\text { A-2) }\end{array}$ & $\begin{array}{c}\text { Slagging } \\
\text { Rotary } \\
\text { Kiln }(A-7) \\
\end{array}$ & $\begin{array}{c}\text { Rotary } \\
\text { Kiln/Grout } \\
\text { (A-8) }\end{array}$ & $\begin{array}{c}\text { Plasma } \\
\text { Furnace } \\
(\mathrm{C}-1)\end{array}$ & $\begin{array}{c}\text { Metal } \\
\text { Melter } \\
(\mathrm{G}-1) \\
\end{array}$ & $\begin{array}{c}\text { Steam } \\
\text { Reforming } \\
(\mathrm{H}-1)\end{array}$ \\
\hline \multicolumn{8}{|l|}{ Primary Treatment Process } \\
\hline Main Thermal Treatment & $68.3 \%$ & $68.3 \%$ & $73.4 \%$ & $68.3 \%$ & $73.4 \%$ & $89.4 \%$ & $22.5 \%$ \\
\hline Vitrifier & $0.0 \%$ & $0.0 \%$ & $0.0 \%$ & $0.0 \%$ & $0.0 \%$ & $0.0 \%$ & $45.8 \%$ \\
\hline Total & $68.3 \%$ & $68.3 \%$ & $73.4 \%$ & $68.3 \%$ & $73.4 \%$ & $89.4 \%$ & $68.3 \%$ \\
\hline Metal/Lead Melters & $5.3 \%$ & $5.3 \%$ & $0.2 \%$ & $5.3 \%$ & $0.2 \%$ & $0.2 \%$ & $5.3 \%$ \\
\hline $\begin{array}{l}\text { Mercury Retort \& } \\
\text { Amalgamation }\end{array}$ & $1.7 \%$ & $1.7 \%$ & $1.7 \%$ & $1.7 \%$ & $1.7 \%$ & $1.7 \%$ & $1.7 \%$ \\
\hline Metal/Lead Decontamination & $16.7 \%$ & $16.7 \%$ & $16.7 \%$ & $16.7 \%$ & $16.7 \%$ & $0.7 \%$ & $16.7 \%$ \\
\hline Aqueous Waste Treatment & $2.7 \%$ & $2.7 \%$ & $2.7 \%$ & $2.7 \%$ & $2.7 \%$ & $2.7 \%$ & $2.7 \%$ \\
\hline Special Waste & $5.2 \%$ & $5.2 \%$ & $5.2 \%$ & $5.2 \%$ & $5.2 \%$ & $5.2 \%$ & $5.2 \%$ \\
\hline Salt to Polymer & $0.03 \%$ & $0.03 \%$ & $0.03 \%$ & $0.03 \%$ & $0.03 \%$ & $0.03 \%$ & $0.03 \%$ \\
\hline
\end{tabular}

Table 2-2. Percent of waste distributed to nonthermal treatment subsystems.

\begin{tabular}{|c|c|c|c|c|c|}
\hline Treatment Subsystems & $\begin{array}{l}\text { Grout } \\
\text { Debris } \\
(\mathrm{NT}-1)\end{array}$ & $\begin{array}{c}\text { Thermal } \\
\text { Desorption } \\
\text { (NT-2) }\end{array}$ & $\begin{array}{l}\text { Wash } \\
(\mathrm{NT}-3)\end{array}$ & $\begin{array}{c}\text { Acid Digestion } \\
(\mathrm{NT}-4)\end{array}$ & $\begin{array}{c}\text { Catalytic Wet } \\
\text { Oxidation } \\
\text { (NI-5) }\end{array}$ \\
\hline \multicolumn{6}{|l|}{ Primary Treatment Processes } \\
\hline Chemical Oxidation Process & $6.3 \%$ & $6.3 \%$ & $6.3 \%$ & $21.2 \%$ & $21.2 \%$ \\
\hline Vacuum Thermal Desorption & $45.6 \%$ & $69.3 \%$ & $0.0 \%$ & $34.4 \%$ & $34.4 \%$ \\
\hline Washing & $0.0 \%$ & $0.0 \%$ & $69.3 \%$ & $14.0 \%$ & $14.0 \%$ \\
\hline Total & $51.9 \%$ & $75.6 \%$ & $75.6 \%$ & $69.6 \%$ & $69.6 \%$ \\
\hline Metal/Lead Decontamination & $16.5 \%$ & $16.5 \%$ & $16.5 \%$ & $16.5 \%$ & $16.5 \%$ \\
\hline Mercury Amalgamation & $0.1 \%$ & $0.1 \%$ & $0.1 \%$ & $0.1 \%$ & $0.1 \%$ \\
\hline Aqueous Waste Treatment & $2.1 \%$ & $2.1 \%$ & $2.1 \%$ & $2.1 \%$ & $2.1 \%$ \\
\hline Special Waste & $5.3 \%$ & $5.3 \%$ & $5.3 \%$ & $5.3 \%$ & $5.3 \%$ \\
\hline Grout Stabilization & $23.8 \%$ & $0.2 \%$ & $0.2 \%$ & $6.2 \%$ & $6.2 \%$ \\
\hline Polymer Stabilization & $0.2 \%$ & $0.2 \%$ & $0.2 \%$ & $0.2 \%$ & $0.2 \%$ \\
\hline
\end{tabular}




\section{SYSTEM COMPARISONS}

\subsection{Land Use}

One of the concerns of the TSWG is the land required for the treatment facilities and the disposal sites; these requirements are shown in Tables 3-1 and 3-2, respectively. The mixed waste is treated in a single facility designed to contain and process contact-handled, alpha-contaminated mixed low-level waste to meet the requirements of the EPA Land Disposal Restrictions. The site layout, for thermal and nonthermal systems, was based on the following considerations and design goals:

- Accept, treat, and temporarily store alpha-contaminated MLLW in anticipated quantities for a period of 20 years

- Provide no long-term disposal of treated waste on-site

- Meet State and Federal regulatory requirements

- Minimize radiation exposure to workers

- Control natural flow of surface water onto and off of the site.

\subsubsection{Treatment Facility Land Use}

The general treatment facility design, shown in Figure 3-1, is divided into a restricted and an unrestricted area. The restricted area will be surrounded by a security fence to meet Chapter 40 of the Code of Federal Regulations, Section 264.14. The fence will provide a buffer zone of $400 \mathrm{ft}$ between the restricted and unrestricted areas. The restricted area will include the waste processing building, waste storage building, fuel dispensing area, restricted area storm runoff detention basin, and all associated roads and paving. Access to the restricted area will be controlled from the site access building. The unrestricted area will include the administration building, site access building, maintenance building, truck inspection building, warehouse building, utility building, electrical supply, firewater storage, access roads, storm water detention pond, and parking area. A perimeter fence surrounding the entire site will be located to satisfy the buffer zone requirements of Chapter 40 of the Code of Federal Regulations, Section 266, Appendix IX - Burning Hazardous Waste in Industrial Boilers and Incinerators.

The size of the waste processing building depends on the number of processing steps required and the amount of equipment necessary to accomplish these steps. Since the treatment systems are used for alpha-contaminated and nonalpha-contaminated waste, they have a tertiary containment system for all process steps from waste sorting through waste stabilization. Only two levels of containment are required for processes involving materials with limited potential for becoming airborne. Details of the facility design are provided in References 1, 2, and 4. As indicated in Table 3-1, the size of the treatment building is larger for the nonthermal systems. However, because of the need for a buffer zone between the restricted and unrestricted areas, and the need for retention ponds, parking, and administrative buildings, the treatment building occupies only 5 to $7 \%$ of the total treatment site area. The bulk of the site is a buffer zone around the treatment buildings, with parking, outbuildings, and utilities making up $30 \%$ of the total site area. The treatment site area varies among systems by only 7 acres. 
Table 3-1. Treatment facility land use requirements.

\begin{tabular}{lccccc}
\hline \multicolumn{1}{c}{ System } & $\begin{array}{c}\text { Building Area } \\
\left(\mathrm{ft}^{2}\right)\end{array}$ & $\begin{array}{c}\text { Area Relative } \\
\text { to A-8 }\end{array}$ & $\begin{array}{c}\text { Treatment Site Area } \\
\mathrm{f}^{2}\end{array}$ & $\begin{array}{c}\text { Building Area to } \\
\text { acres }\end{array}$ & \begin{tabular}{c} 
Total Site Area \\
\hline Rotary Kiln/Air (A-1)
\end{tabular} \\
120000 & 0.97 & 2240000 & 51.5 & 0.054 \\
Rotary Kiln/Oxygen (A-2) & 119000 & 0.96 & 2240000 & 51.5 & 0.053 \\
Slagging Rotary Kiln (A-7) & 109000 & 0.88 & 2180000 & 50.1 & 0.050 \\
Rotary Kiln/Grout (A-8) & 124000 & 1.00 & 2260000 & 52.0 & 0.055 \\
Plasma Furnace (C-1) & 111000 & 0.90 & 2200000 & 50.6 & 0.050 \\
Metal Melter (G-1) & 112000 & 0.90 & 2200000 & 50.6 & 0.051 \\
Steam Reforming (H-1) & 119000 & 0.96 & 2240000 & 51.5 & 0.053 \\
Grout Debris (NT-1) & 152000 & 1.23 & 2410000 & 55.4 & 0.063 \\
Thermal Desorption (NT-2) & 149000 & 1.20 & 2390000 & 55.0 & 0.062 \\
Wash (NT-3) & 152000 & 1.23 & 2410000 & 55.4 & 0.063 \\
Acid Digestion (NT-4) & 170000 & 1.37 & 2500000 & 57.5 & 0.068 \\
Catalyzed Wet Ox (NT-5) & 160000 & 1.29 & 2450000 & 56.4 & 0.065 \\
\hline
\end{tabular}

Table 3-2. Disposal site land use requirements.

\begin{tabular}{lccccc}
\hline \multicolumn{1}{c}{ System } & $\begin{array}{c}\text { Disposal Volume } \\
\left(\mathrm{ft}^{3} \text { /hour) }\right.\end{array}$ & $\begin{array}{c}20 \text { Yr Disposal } \\
\text { Volume }\left(\mathrm{ft}^{3}\right)\end{array}$ & $\begin{array}{c}\text { Disposal Site Area } \\
\mathrm{ft}^{2}\end{array}$ & $\begin{array}{c}\text { Size Relative to } \\
\text { acres }\end{array}$ & \begin{tabular}{l} 
System A-8 \\
\hline Rotary Kiln/Air (A-1)
\end{tabular} \\
13.6 & $1,100,000$ & $6,750,000$ & 155.3 & 0.82 \\
Rotary Kiln/Oxygen (A-2) & 13.6 & $1,100,000$ & $6,750,000$ & 155.3 & 0.82 \\
Slagging Rotary Kiln (A-7) & 14.5 & $1,170,000$ & $6,750,000$ & 155.3 & 0.82 \\
Rotary Kiln/Grout (A-8) & 31.1 & $2,510,000$ & $8,250,000$ & 189.8 & 1.00 \\
Plasma Furnace (C-1) & 13.2 & $1,060,000$ & $6,750,000$ & 155.3 & 0.82 \\
Metal Melter (G-1) & 11.5 & 930,000 & $6,500,000$ & 149.5 & 0.79 \\
Steam Reforming (H-1) & 13.6 & $1,100,000$ & $6,750,000$ & 155.3 & 0.82 \\
Grout Debris (NT-1) & 42.5 & $3,430,000$ & $9,300,000$ & 213.5 & 1.13 \\
Thermal Desorption (NT-2) & 42.2 & $3,400,000$ & $9,000,000$ & 206.6 & 1.09 \\
Wash (NT-3) & 40.8 & $3,290,000$ & $9,000,000$ & 206.6 & 1.09 \\
Acid Digestion (NT-4) & 37.6 & $3,000,000$ & $8,700,000$ & 199.8 & 1.05 \\
Catalyzed Wet Ox (NT-5) & 36.1 & $2,910,000$ & $8,700,000$ & 199.8 & 1.05 \\
\hline
\end{tabular}




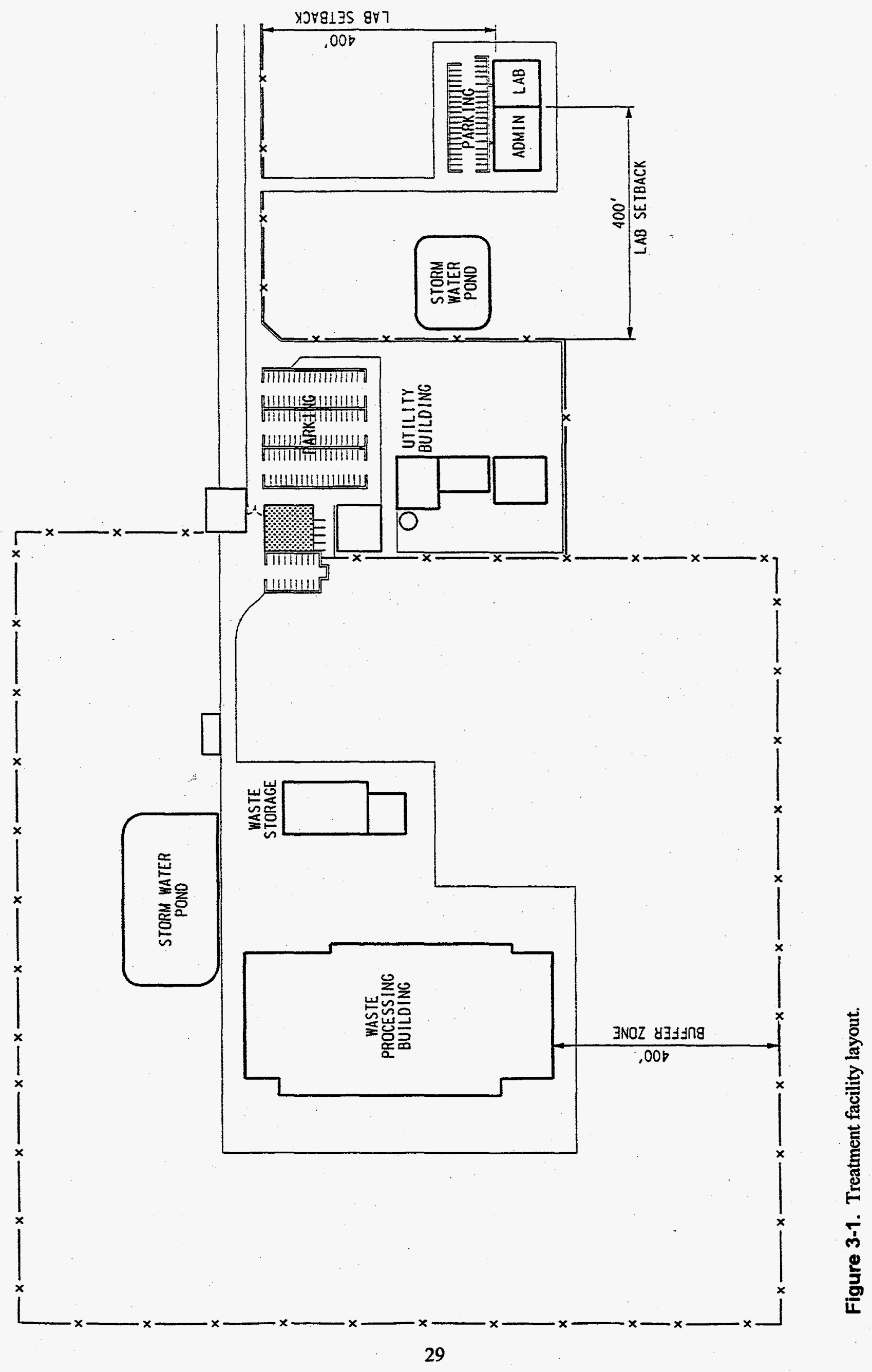




\subsubsection{Disposal Land Use}

The disposal site, shown in Figure 3-2, is designed to accept the volume of stabilized waste generated by the treatment facility over a period of 20 years. The disposal site is also divided into restricted and unrestricted areas. The restricted area contains the disposal modules (stacked $31 \mathrm{ft} \mathrm{high}$ ), access roads, storm water runoff retention ponds, a waste packaging building, a waste package storage building, and access control buildings. The restricted area is contained within a 1,000 foot buffer zone. Outside this buffer zone are maintenance buildings, administrative buildings, and construction material storage and parking areas.

The total waste volume requiring disposal varies from 1 to 3.5 million $\mathrm{ft}^{3}$ depending on the system; however, increasing the volume of waste by a factor of 4 only increases the size of the disposal site by $40 \%$. The systems that use nonthermal stabilization methods (all nonthermal systems and System A-8) require larger disposal sites because of their larger volume of final waste. Systems that use vitrification for stabilization have lower volume final waste forms and, therefore, a smaller disposal site area. As indicated in Table 3-2, the disposal site size varies from 150 acres for System G-1 to 214 acres for System NT-1. Systems NT-1, NT-2, and NT-3 require larger areas because all soft debris is stabilized in grout. The nonthermal systems that decrease the volume of, or eliminate, soft debris (Systems NT-4 and NT-5) have less waste to be stabilized and disposed. System G-1 has the least amount of solid waste sent to disposal because it has no quench water and the least amount of scrubber liquor from the APC system and, therefore, the least amount of polymer-stabilized salts. All the metal is assumed to be recycled.

Provision of buffer zones around both the treatment and disposal facilities, and siting such facilities in unpopulated areas, will minimize the effects of noise and unsightly industrial processes on the public.

\subsection{Effluent Comparison}

This section compares the effluent from the thermal and nonthermal systems and addresses the TSWG Principle "Minimize Effluent." The effluent to be compared includes the following:

- Gaseous effluent, including the major nontoxic components of the offgas exiting the stack

- Treated aqueous waste that is discharged

- Solid effluent sent to disposal

- The quantity of metals treated and stored for subsequent recycle into the DOE complex.

The total effluent from the nonthermal and thermal systems is shown in Table 3-3. Nonthermal systems have significantly less offgas than thermal systems but more solids sent to disposal. Because of the significantly higher offgas from thermal systems, the total effluent from the thermal systems is much greater than that from nonthermal systems. 


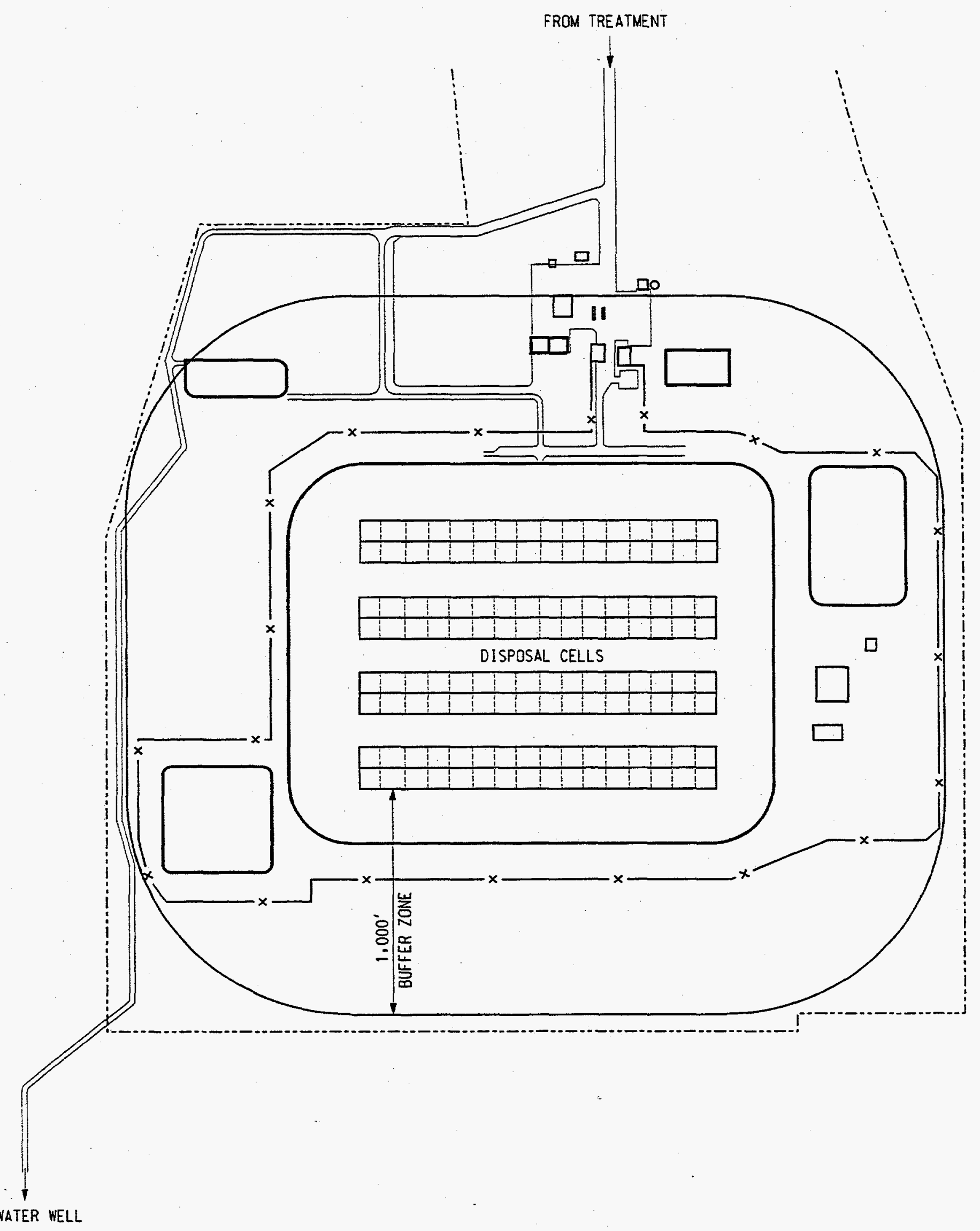

Figure 3-2. Disposal facility layout 
Table 3-3a. Effluent from thermal systems (lbs/hr).

\begin{tabular}{|c|c|c|c|c|c|c|c|}
\hline $\begin{array}{l}\text { Effluent } \\
\text { (lbs/hr) }\end{array}$ & $\begin{array}{c}\text { Rotary } \\
\text { Kiln/Air } \\
\text { (A-1) }\end{array}$ & $\begin{array}{c}\text { Rotary } \\
\text { Kiln/Oxygen } \\
\text { (A-2) }\end{array}$ & $\begin{array}{c}\text { Slagging } \\
\text { Rotary Kiln } \\
\text { (A-7) } \\
\end{array}$ & $\begin{array}{c}\text { Rotary } \\
\text { Kiln/Grout } \\
\text { (A-8) }\end{array}$ & $\begin{array}{c}\text { Plasma } \\
\text { Furnace } \\
(\mathrm{C}-1) \\
\end{array}$ & $\begin{array}{c}\text { Metal } \\
\text { Melter } \\
\text { (G-1) }\end{array}$ & $\begin{array}{c}\text { Steam } \\
\text { Reforming } \\
(\mathrm{H}-1) \\
\end{array}$ \\
\hline Offgas & 20697 & 5874 & 26437 & 20897 & 6895 & 11585 & 11648 \\
\hline Wastewater & 399 & 888 & 778 & -36 & 463 & 87 & -487 \\
\hline Clean Metal to Recycle & 622 & 622 & 488 & 622 & 658 & 638 & 622 \\
\hline Clean Lead & 25 & 25 & 25 & 25 & 25 & 25 & 25 \\
\hline Clean Ferrous Metal & 597 & 597 & 463 & 597 & 633 & 613 & 597 \\
\hline Solids to Disposal & 1929 & 1929 & 2102 & 3667 & 1861 & 1793 & 1927 \\
\hline Hg Amalgam & 11 & 11 & 11 & 11 & 11 & 11 & 11 \\
\hline Grout & 1 & 1 & 1 & 3234 & 1 & 1 & 1 \\
\hline Polymer & 246 & 246 & 246 & 245 & 246 & 56 & 246 \\
\hline Special Waste & 153 & 153 & 153 & 153 & 153 & 153 & 153 \\
\hline Slag/Glass & 1519 & 1519 & 1692 & 24 & 1451 & 1573 & 1517 \\
\hline $\begin{array}{l}\text { Total Effluent } \\
\text { (excluding clean metal) }\end{array}$ & 23025 & 8691 & 29317 & 24527 & 9219 & 13465 & 13088 \\
\hline
\end{tabular}

Table 3-3b. Effluent from nonthermal systems (lbs/hr).

\begin{tabular}{lccccc}
\hline $\begin{array}{c}\text { Effluent } \\
\text { (lbs/hr) }\end{array}$ & $\begin{array}{c}\text { Grout } \\
\text { Debris } \\
(\text { NT-1) }\end{array}$ & $\begin{array}{c}\text { Thermal Desorption } \\
\text { (NT-2) }\end{array}$ & $\begin{array}{c}\text { Wash } \\
(\text { NT-3) }\end{array}$ & $\begin{array}{c}\text { Acid Digestion } \\
\text { (NT-4) }\end{array}$ & $\begin{array}{c}\text { Catalytic Wet } \\
\text { Oxidation } \\
\text { (NT-5) }\end{array}$ \\
\hline Offgas & 696 & 823 & 827 & 1441 & 1433 \\
Wastewater & 59 & 135 & 176 & 780 & 564 \\
Clean Metal to Recycle & 451 & 451 & 451 & 451 & 451 \\
$\quad$ Clean Lead & 21 & 21 & 21 & 21 & 21 \\
$\quad$ Clean Ferrous Metal & 430 & 430 & 430 & 430 & 430 \\
Solids to Disposal & 4675 & 4616 & 4468 & 3664 & 3819 \\
$\quad$ Hg Amalgam & 5 & 9 & 4 & 5 & 5 \\
$\quad$ Grout & 2913 & 2764 & 2731 & 783 & 1938 \\
$\quad$ Polymer & 1602 & 1688 & 1578 & 13 & 1722 \\
$\quad$ Ceramic & 0 & 0 & 0 & 2708 & 0 \\
$\quad$ Special Waste & 155 & 155 & 155 & 155 & 155 \\
Total Effluent & 5429 & 5574 & 5471 & 5885 & 5817 \\
(excluding clean metal) & & & & & \\
\hline
\end{tabular}




\subsubsection{Gaseous Effluent}

The major source of gaseous effluent from thermal systems is the main thermal treatment unit, the secondary source is the vitrification system. Gases are also generated in the steel and lead melters and in the mercury retort. The sources of gaseous effluent from nonthermal system are varied and include the thermal desorber, chemical oxidation, and aqueous waste treatment.

The system with the highest amount of offgas is System A-7, which requires more air and fuel to achieve the higher temperatures to produce a slag. Systems that use air for combustion (e.g., Systems A-1, A-7, and A-8) use excess air to ensure adequate mixing of the fuel and waste with oxygen, and to provide temperature control for high BTU wastes. These systems have high gaseous effluent because of the excess oxygen and nitrogen contained in the air, whereas systems that use oxygen (e.g., System A-2) have onethird to one-fourth the amount of offgas produced by systems that use air. Although the plasma furnace uses air to combust the organic waste, heat is provided by an electrical discharge rather than combustion of additional fuel so that much less air is required and much less offgas is generated. Systems G-1 and H-1 react the waste under reducing, or starved air, conditions and produce a combustible gas (syngas) that is oxidized with excess air in a catalytic or thermal oxidizer. Because these systems use little or no air in the primary thermal treatment unit, the offgas produced is about one-half that produced by systems that use air for direct combustion of the waste in a rotary kiln in addition to combustion in a secondary combustion chamber.

Of the nonthermal systems, those that oxidize all the organic waste, including soft (or combustible) debris (e.g., NT-4 and NT-5), have the highest quantity of offgas. This is a consequence of oxidizing the organic material to carbon dioxide and water to decrease the volume of solid waste requiring stabilization and disposal.

The offgas composition from thermal and nonthermal systems is shown in Table 3-4, and shown graphically in Figures 3-3 and 3-4, respectively. The offgas from those thermal systems that use air for combustion is about 10 to 20 times that of the offgas from nonthermal systems, whereas the offgas from systems that use oxygen for combustion, electric heating, or a reducing atmosphere are about 5 to 10 times the offgas from nonthermal systems. This is because of the nitrogen in the air (air is approximately $79 \%$ $\mathrm{N}_{2}$ ), which passes through the thermal treatment process essentially unaffected.

The primary constituent of the gaseous effluent from the nonthermal systems is carbon dioxide $\left(\mathrm{CO}_{2}\right)$, which is produced as a direct result of oxidizing the organic constituents of the waste. Nitrogen used as the sweep gas in the vacuum thermal desorber in Systems NT-1, NT-2, NT-4, and NT-5 is treated in the APC system and exhausted to the atmosphere. Nitrogen and $\mathrm{NO}_{\mathrm{x}}$ is also generated as a byproduct from the destruction organic compounds containing nitrogen. Decomposition of the combustible (or soft) debris in Systems NT-4 and NT-5 releases gases containing nitrogen, and additional nitrogen is produced in Systems NT-1, NT-3, and NT-4 by the reaction of ammonia with $\mathrm{NO}_{\mathrm{x}}$ resulting from the decomposition of nitric acid. The ammonia is added to decrease the $\mathrm{NO}_{\mathrm{x}}$ in the gaseous effluent. Excess oxygen is used in the gas-phase corona reactor in the air pollution control system to ensure complete oxidation of trace organics in the offgas; thus, small amounts of oxygen also occur in the offgas.

The primary constituent of the gaseous effluent from thermal systems is nitrogen. Typically, excess air (or oxygen) is used to ensure complete combustion, so a significant amount of nitrogen and excess oxygen passes through these systems and is released to the atmosphere. Rotary kiln systems that use oxygen for combustion (e.g., A-2) have a relatively large quantity of nitrogen in the offgas (when compared to the nonthermal systems) because of air inflow to the primary combustion chamber caused 
Table 3-4a. Composition of offgas from thermal systems.

\begin{tabular}{|c|c|c|c|c|c|c|c|}
\hline $\begin{array}{c}\text { Offgas } \\
\text { Composition } \\
\text { (lbs/hr) }\end{array}$ & $\begin{array}{c}\text { Rotary } \\
\text { Kiln/Air } \\
\text { (A-1) }\end{array}$ & $\begin{array}{c}\text { Rotary } \\
\text { Kiln/Oxygen } \\
\text { (A-2) }\end{array}$ & $\begin{array}{c}\text { Slagging } \\
\text { Rotary Kiln } \\
\text { (A-7) }\end{array}$ & $\begin{array}{c}\text { Rotary } \\
\text { Kiln/Grout } \\
\text { (A-8) }\end{array}$ & $\begin{array}{c}\text { Plasma } \\
\text { Furnace } \\
\text { (C-1) }\end{array}$ & $\begin{array}{c}\text { Metal Melter } \\
\text { (G-1) }\end{array}$ & $\begin{array}{c}\text { Steam } \\
\text { Reforming } \\
(\mathrm{H}-1) \\
\end{array}$ \\
\hline Oxygen & 1625 & 1387 & 1489 & 1633 & 258 & 1215 & 1124 \\
\hline Nitrogen & 14730 & 2062 & 19523 & 14849 & 4781 & 8000 & 7551 \\
\hline Water Vapor & 1478 & 357 & 1923 & 1877 & 485 & 883 & 1477 \\
\hline Carbon Dioxide & 2364 & 1569 & 3366 & 2356 & 1236 & 1351 & 1314 \\
\hline Undefined & 497 & 497 & 133 & 179 & 133 & 133 & 179 \\
\hline Sulfur Dioxide & 3 & 2 & 3 & 3 & 2 & 3 & 3 \\
\hline Total & 20697 & 5874 & 26437 & 20897 & 6895 & 11585 & 11648 \\
\hline
\end{tabular}

Table 3-4b. Composition of offgas from nonthermal systems.

\begin{tabular}{lccccc}
\hline $\begin{array}{c}\text { Offgas Composition } \\
\text { (lbs/hr) }\end{array}$ & $\begin{array}{c}\text { Grout Debris } \\
\text { (NT-1) }\end{array}$ & $\begin{array}{c}\text { Thermal Desorption } \\
\text { (NT-2) }\end{array}$ & $\begin{array}{c}\text { Wash } \\
\text { (NT-3) }\end{array}$ & $\begin{array}{c}\text { Acid Digestion } \\
\text { (NT-4) }\end{array}$ & $\begin{array}{c}\text { Catalytic Wet } \\
\text { Oxidation (NT-5) }\end{array}$ \\
\hline Oxygen & 29.1 & 35.6 & 55.1 & 10.4 & 30.9 \\
Nitrogen & 117.9 & 165.1 & 18.9 & 132.1 & 84.2 \\
Nitrogen Oxide & 0.8 & 0.7 & 0.8 & 0.2 & 0.7 \\
Water Vapor & 9.8 & 1.8 & 15.2 & 10.5 & 3.8 \\
Carbon Dioxide & 537.9 & 619.8 & 737 & 1288 & 1313.6 \\
Total & 695.5 & 823 & 827 & 1441.2 & 1433.2 \\
\hline
\end{tabular}




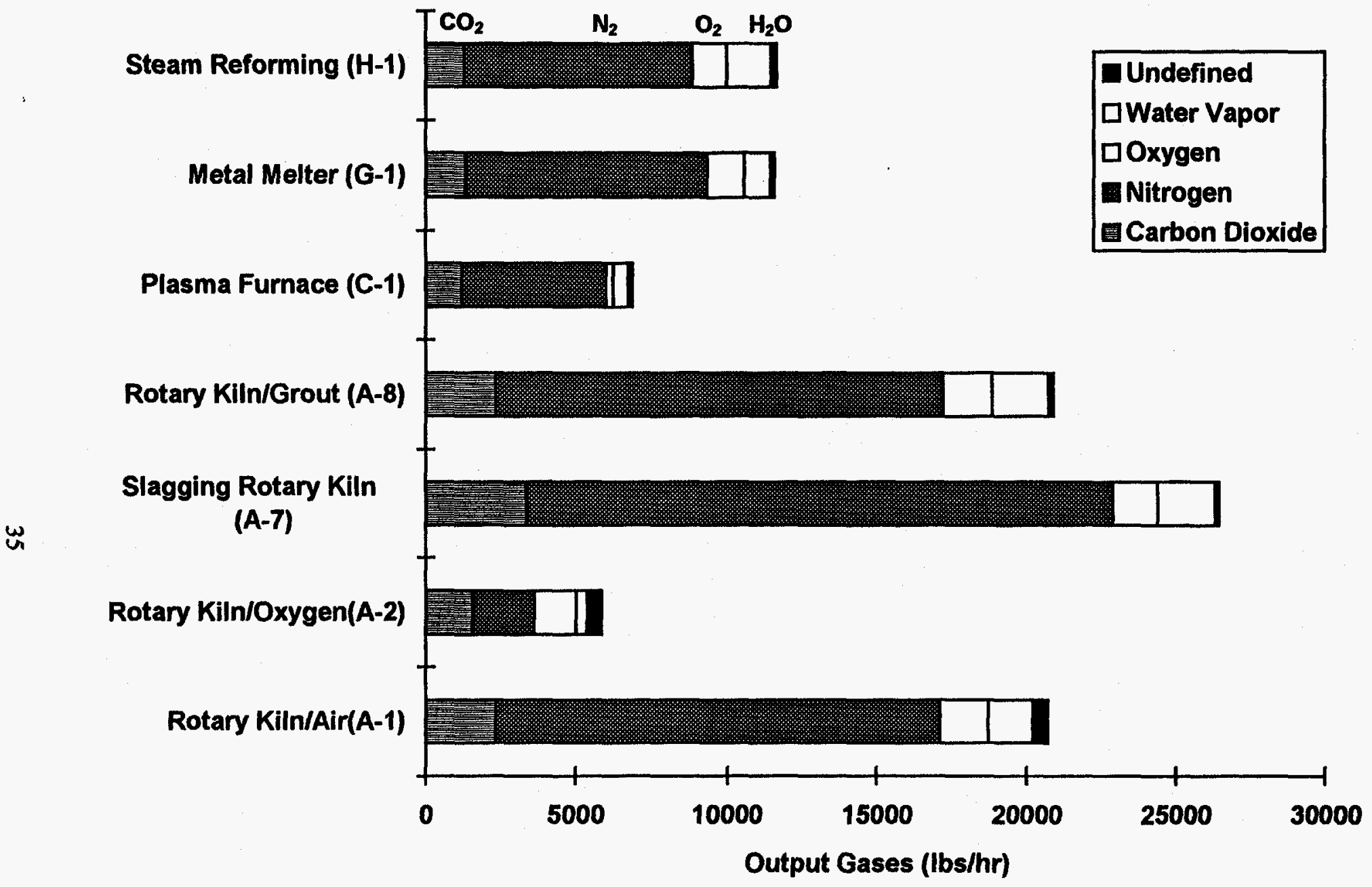

Figure 3-3. Offgas composition from thermal systems. 


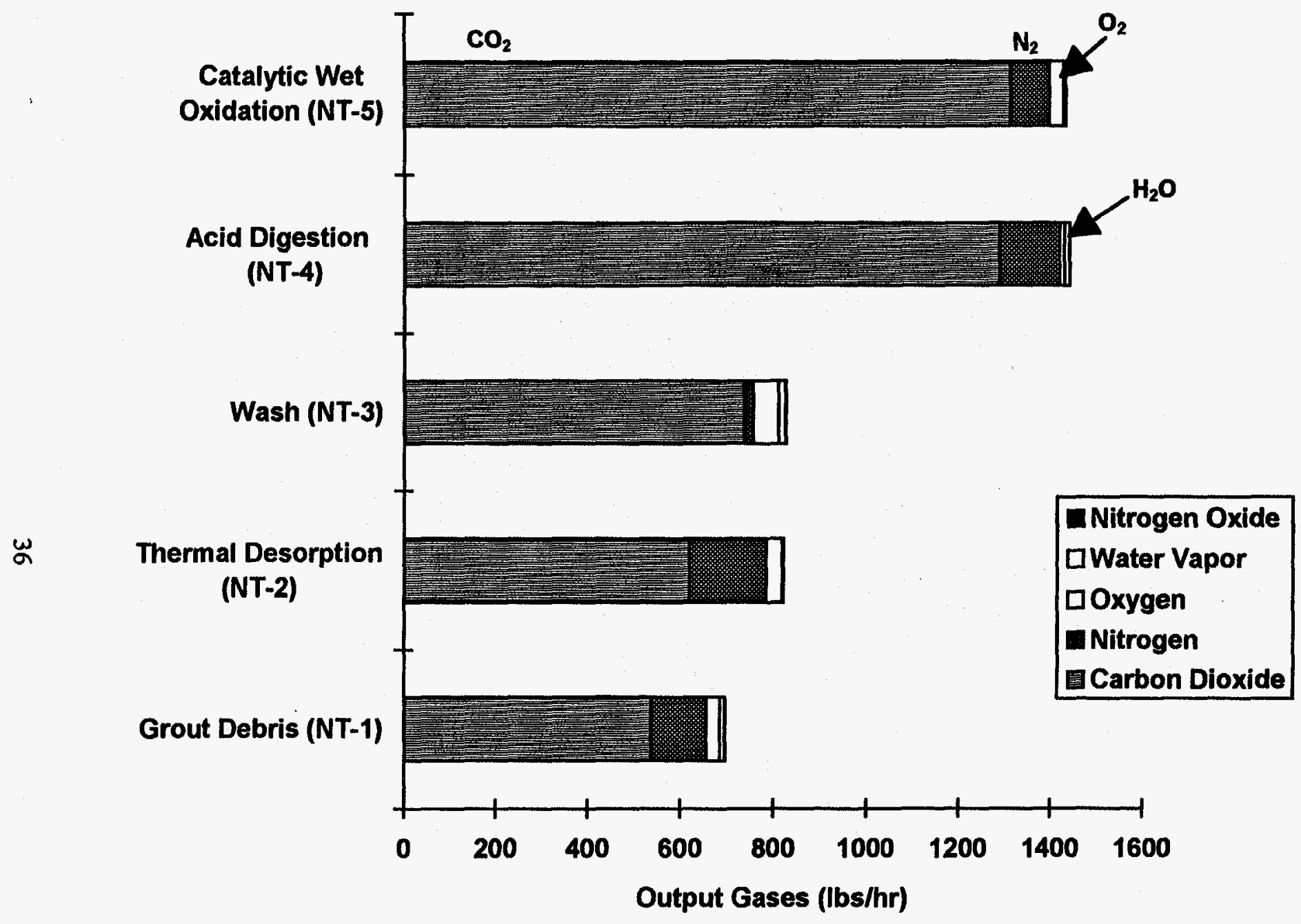

Figure 3-4. Offgas composition from nonthermal systems. 
by operating these systems under a negative pressure. Nitrogen in the offgas from systems that use a reducing atmosphere (e.g., G-1 and $\mathrm{H}-1$ ) is from combustion, in the thermal oxidizers, of the syngas (consisting of carbon monoxide, hydrogen, and methane) produced by the reduction reactions. Thermal systems that use oxygen or a reducing atmosphere, or that use electricity for heat, emit approximately the same amount of $\mathrm{CO}_{2}$ as Systems NT-4 and NT-5 (the nonthermal systems that treat the combustible debris) from oxidation of organic material in the waste. However, Systems A-1, A-7, and A-8 emit 2 to 3 times this amount because these three systems burn significantly more methane in the main thermal treatment subsystem and secondary combustion chamber.

The undefined offgas shown in Table 3-4 results from the ancillary treatment units including metal melting, lead recovery, mercury amalgamation, and vitrification. This offgas passes through individual air pollution control systems and contains primarily combustion products from burning methane for process heat or from combusting methane and trace organics in a secondary combustion chamber. The specific, quantitative composition of these small offgas streams was not determined in the mass balance analysis but is expected to be primarily $\mathrm{O}_{2}, \mathrm{CO}_{2}, \mathrm{H}_{2} \mathrm{O}$, and $\mathrm{N}_{2}$.

\subsubsection{Wastewater Effluent}

For thermal treatment systems, quench and scrubber water from the APC subsystem constitute the bulk of the water sent to the aqueous waste treatment system, followed by rinse water and water from metal decontamination. For nonthermal systems, the wastewater sources are varied; they include the APC, chemical oxidation, soil treatment and debris washing, metal decontamination, and polymer stabilization subsystems.

The water leaving the water treatment subsystem is recycled to meet the needs of the total treatment system, and only the excess water is discharged. Generally, more water is generated by the oxidation of organic matter and treatment of water entering with the stored waste than is required by the system. However, Systems A-8 and H-1 require more water than is generated by the treatment systems, and therefore they consume small quantities of water. The percentage of water leaving the water treatment subsystem that is recycled is shown on the system flowsheets in Figures 2-1 through 2-12; the wastewater discharge and consumption rates are shown in Table 3-3.

\subsubsection{Solids to Disposal}

The treated incoming inorganic solid waste is the primary source of solids sent to disposal. In thermal systems, the organic material is combusted, producing a bottom ash and gases with entrained particulates that are removed in the APC subsystem as flyash. The bottom ash and flyash are subsequently vitrified or stabilized in grout. Lead and steel melters produce a slag residue and metal for recycle, mercury treatment produces an amalgam for disposal, and the APC and aqueous waste treatment systems generate salt that is stabilized in polymer.

In nonthermal systems, solid waste comes from debris, soil, or sludge that has been treated in the thermal desorber or in the washing processes. Chemical oxidation generates a sludge similar to the ash from thermal treatment, metal surface decontamination produces a sludge, and mercury treatment produces an amalgam for disposal. All residues are stabilized in grout or polymer, and the APC and aqueous waste treatment systems generate salt that is stabilized in polymer.

One of the TSWG subprinciples is to "minimize the volume of waste sent to final disposal and storage." Figure 3-5 illustrates the amounts of waste sent to disposal from the various systems. Table 3-5 


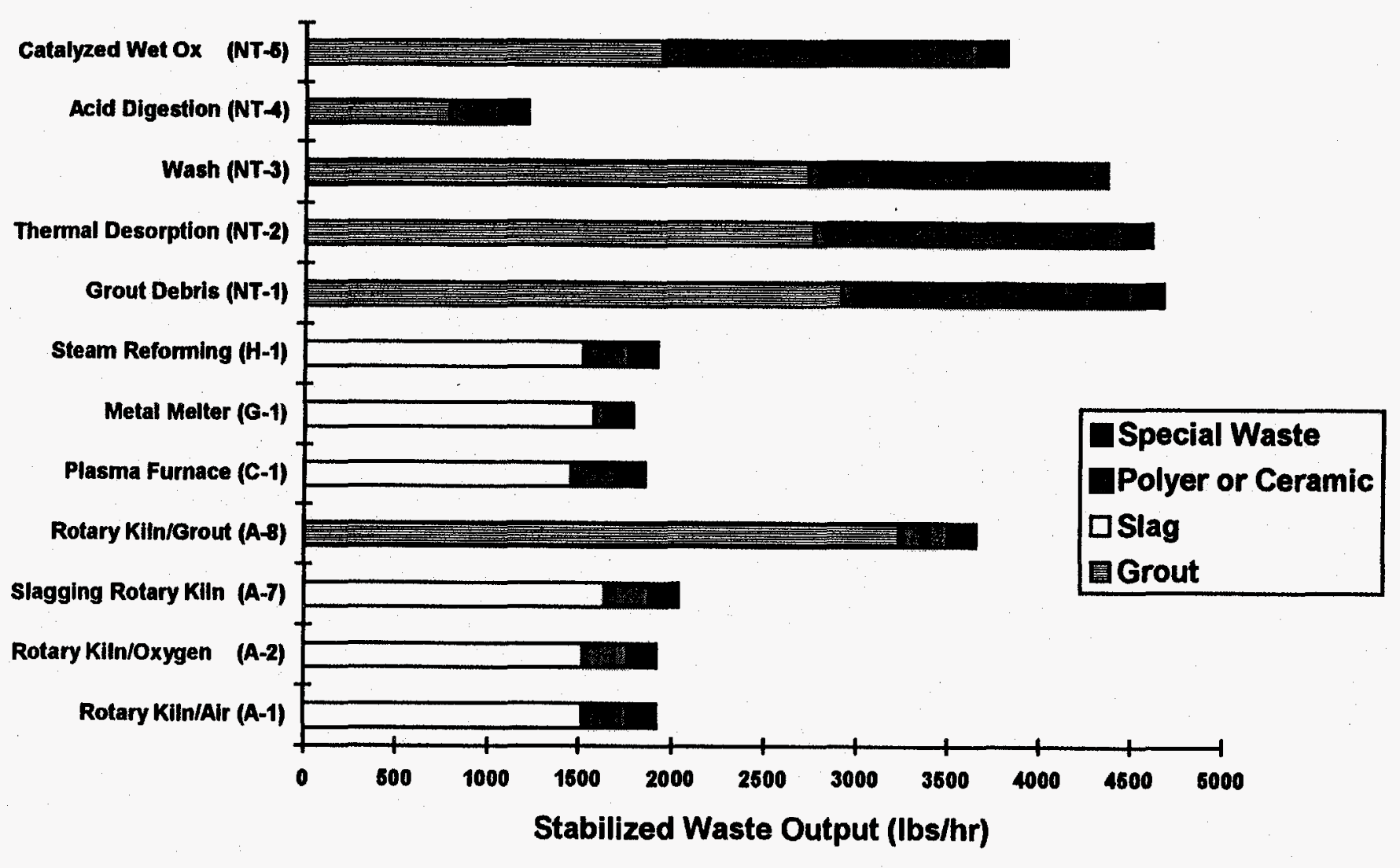

Figure 3-5. Stabilized waste sent to disposal. 
Table 3-5. Ratios of waste input volumes to volumes of waste sent to disposal.

\begin{tabular}{lccc}
\multicolumn{1}{c}{ System } & Vol In/Vol Out & Vol Out/Vol In & $\begin{array}{c}\text { Output Volume } \\
\text { Relative to A-8 }\end{array}$ \\
Rotary Kiln/Air (A-1) & 3.37 & 0.30 & 0.44 \\
Rotary Kiln/Oxygen (A-2) & 3.37 & 0.30 & 0.44 \\
Slagging Rotary Kiln (A-7) & 3.16 & 0.32 & 0.47 \\
Rotary Kiln/Grout (A-8) & 1.47 & 0.68 & 1.00 \\
Plasma Furnace (C-1) & $3.46^{*}$ & $0.29^{*}$ & $0.42^{*}$ \\
Metal Melter (G-1) & $3.97^{*}$ & $0.25^{*}$ & $0.37^{*}$ \\
Steam Reforming (H-1) & 3.37 & 0.30 & 0.44 \\
Grout Debris (NT-1) & 1.05 & 0.95 & 1.40 \\
Thermal Desorption (NT-2) & 1.06 & 0.94 & 1.39 \\
Wash (NT-3) & 1.1 & 0.91 & 1.34 \\
Acid Digestion (NT-4) & 1.19 & 0.84 & 1.24 \\
Catalyzed Wet Ox (NT-5) & 1.24 & 0.81 & 1.19 \\
\hline * Vendor claims for recycle of metal may not be justified on the basis of metal composition or economics. \\
If disposal credit were disallowed, the disposal would be similar to System A-7.
\end{tabular}

provides the volume reduction from treating $45 \mathrm{ft}^{3} / \mathrm{hr}$ of input waste for thermal and nonthermal systems, and Figure 3-6 shows the volume of waste leaving the facility as a percentage of the waste volume entering the facility. The distribution of primary and secondary waste sent to disposal in terms of mass and volume is shown in Table 3-6. The percent, by volume, of the waste sent to disposal that is in each of the various final waste forms is shown in Figure 3-7 for each system.

Nonthermal systems exhibit relatively low volume reduction for three reasons:

- Nonthermal stabilization technologies require significant amounts of stabilization agents

- The final waste form is less dense than glass or slag, so the resulting volume is higher, and

- Soft, or combustible, debris is destroyed in only two nonthermal systems.

Nonthermal stabilization technologies require significant amounts of stabilization agents. For example, the assumed recipe for grout is 2 parts, by weight, grout mixture (cement and water) to 1 part waste; the ratios for polymer and ceramic are 1 part polymer or magnesium phosphate to 1 part waste. In contrast, the recipe assumed for vitrification is 1 part soil to 2 parts waste residue. In addition, the density of slag is about $187 \mathrm{lbs} / \mathrm{ft}^{3}$ compared to $94 \mathrm{lbs} / \mathrm{ft}^{3}$ for polymerized sludge and $127 \mathrm{lbs} / \mathrm{ft}^{3}$ for grouted debris. Thus, a given mass of waste stabilized in slag or glass will have less volume than the same mass stabilized in polymer or grout. 


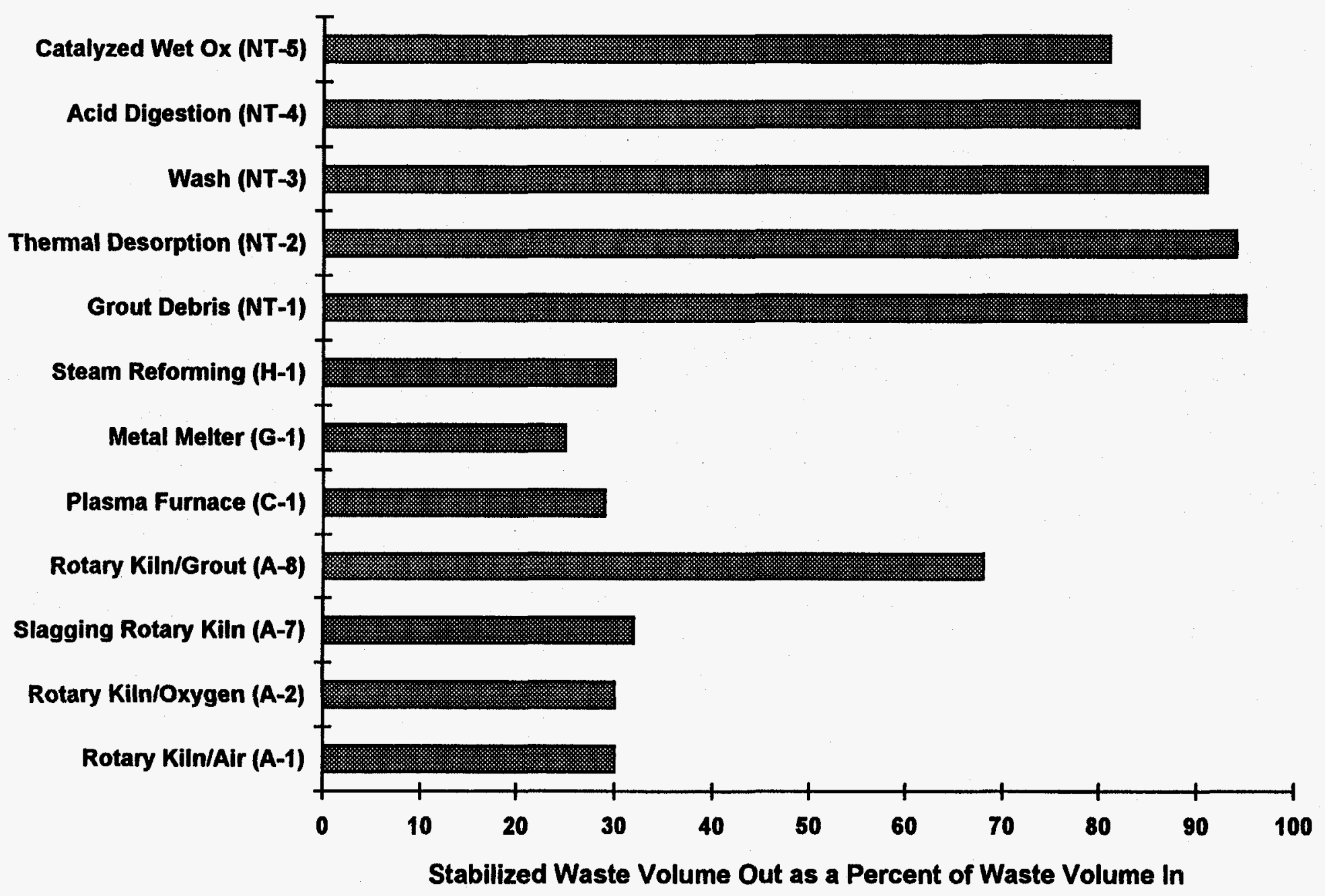

Figure 3-6. Stabilized waste volume as a percent of waste volume entering the treatment facility. 
Table 3-6a. Mass of solid residue sent to disposal (lbs/hr).

\begin{tabular}{|c|c|c|c|c|c|c|}
\hline System & $\begin{array}{l}\text { Primary } \\
\text { Residue }^{\mathrm{b}}\end{array}$ & $\begin{array}{l}\text { Secondary } \\
\text { Residue }^{\mathbf{c}}\end{array}$ & $\begin{array}{c}\text { Mercury } \\
\text { Amalgam } \\
\end{array}$ & Grout & $\begin{array}{l}\text { Polymer or } \\
\text { Ceramic }^{\mathrm{d}}\end{array}$ & Slag \\
\hline Rotary Kiln/Air (A-1) & 1518.8 & 246.9 & 10.5 & 0.9 & 246 & 1519 \\
\hline Rotary Kiln/Oxygen (A-2) & 1518.8 & 246.9 & 10.5 & 0.9 & 246 & 1519 \\
\hline Slagging Rotary Kiln (A-7) & 1691.8 & 246.9 & 10.5 & 0.9 & 246 & 1692 \\
\hline Rotary Kiln/Grout (A-8) & 3257.1 & 245.9 & 10.5 & 3234 & 245 & 24 \\
\hline Plasma Furnace (C-1) & 1450.8 & 246.9 & 10.5 & 0.9 & 246 & 1451 \\
\hline Metal Melter (G-1) & 1572.8 & 56.9 & 10.5 & 0.9 & 56 & 1573 \\
\hline Steam Reforming (H-1) & 1516.8 & 246.9 & 10.5 & 0.9 & 246 & 1517 \\
\hline Grout Debris (NT-1) & 4297.3 & 218.2 & 4.5 & 2913.3 & 1602.2 & 0 \\
\hline Thermal Desorption (NT-2) & 4140.7 & 311.4 & 8.8 & 2764.3 & 1687.6 & 0 \\
\hline Wash (NT-3) & 4069.4 & 239.4 & 4.3 & 2731 & 1577.8 & 0 \\
\hline Acid Digestion (NT-4) & 3107.1 & 397.2 & 4.5 & 783.1 & 2721.1 & 0 \\
\hline Catalyzed Wet Ox (NT-5) & 3314.6 & 345.0 & 4.5 & 1937.8 & 1722 & 0 \\
\hline
\end{tabular}

Table does not include special waste sent to disposal ( $154.9 \mathrm{lbs} / \mathrm{hr}$ from nonthermal systems, $153 \mathrm{lbs} / \mathrm{hr}$ from thermal systems).
a. Primary residue in nonthermal systems consists of all the treated or untreated waste stabilized in grout, polymer, or phosphate-bonded ceramic. In thermal systems, primary residue is the slag or, in the case of System A-8, the grouted waste.
b. Secondary residue consists of the polymer- or ceramic-stabilized salts generated by the treatment processes.
c. Only System NT-4 (Acid Digestion) uses phosphate-bonded ceramic for primary stabilization with polymer for stabilization of soluble salts. 
Table 3-6b. Volume of solid residue sent to disposal (cubic feet/hr) .

\begin{tabular}{|c|c|c|c|c|c|c|c|c|}
\hline System & $\begin{array}{l}\text { Primary } \\
\text { Residue }^{\mathrm{a}}\end{array}$ & $\begin{array}{l}\text { Secondary } \\
\text { Residue }^{b}\end{array}$ & $\begin{array}{l}\text { Mercury } \\
\text { Amalgam } \\
\end{array}$ & Grout & $\begin{array}{l}\text { Polymer or } \\
\text { Ceramic }^{c}\end{array}$ & Slag & $\begin{array}{l}\text { Special } \\
\text { Waste } \\
\end{array}$ & $\begin{array}{c}\text { Total } \\
\text { Volume } \\
\end{array}$ \\
\hline Rotary Kiln/Air (A-1) & 8.1 & 3.1 & 0.01 & 0.01 & 3.1 & 8.1 & 2.4 & 13.6 \\
\hline Rotary Kiln/Oxygen (A-2) & 8.1 & 3.1 & 0.01 & 0.01 & 3.1 & 8.1 & 2.4 & 13.6 \\
\hline Slagging Rotary Kiln (A-7) & 9.0 & 3.1 & 0.01 & 0.01 & 3.1 & 9.0 & 2.4 & 14.5 \\
\hline Rotary Kiln/Grout (A-8) & 25.7 & 3.1 & 0.01 & 25.5 & 3.1 & 0.1 & 2.4 & 31.1 \\
\hline Plasma Furnace (C-1) & 7.8 & 3.1 & 0.01 & 0.01 & 3.1 & 7.8 & 2.4 & 13.2 \\
\hline Metal Melter (G-1) & 8.4 & 0.7 & 0.01 & 0.01 & 0.7 & 8.4 & 2.4 & 11.5 \\
\hline Steam Reforming (H-1) & 8.1 & 3.1 & 0.01 & 0.01 & 3.1 & 8.1 & 2.4 & 13.6 \\
\hline Grout Debris (NT-1) & 37.7 & 2.3 & 0.006 & 23.0 & 17 & 0 & 2.4 & 42.5 \\
\hline Thermal Desorption (NT-2) & 36.5 & 3.3 & 0.012 & 21.8 & 18 & 0 & 2.4 & 42.2 \\
\hline Wash (NT-3) & 35.8 & 2.6 & 0.001 & 21.6 & 16.8 & 0 & 2.4 & 40.8 \\
\hline Acid Digestion (NT-4) & 30.9 & 4.3 & 0.006 & 6.2 & 28.9 & 0 & 2.4 & 37.6 \\
\hline Catalyzed Wet Ox (NT-5) & 30.0 & 3.7 & 0.006 & 15.3 & 18.3 & 0 & 2.4 & 36.1 \\
\hline
\end{tabular}

a. Primary residue in nonthermal systems consists of all the treated or untreated waste stabilized in grout, polymer, or phosphate-bonded ceramic. In thermal systems, primary residue is the slag or, in the case of System A-8, the grouted waste.

b. Secondary residue consists of the polymer- or ceramic-stabilized salts generated by the treatment processes.

c. Only System NT-4 (Acid Digestion) uses phosphate-bonded ceramic for primary stabilization with polymer for stabilization of soluble salts. 


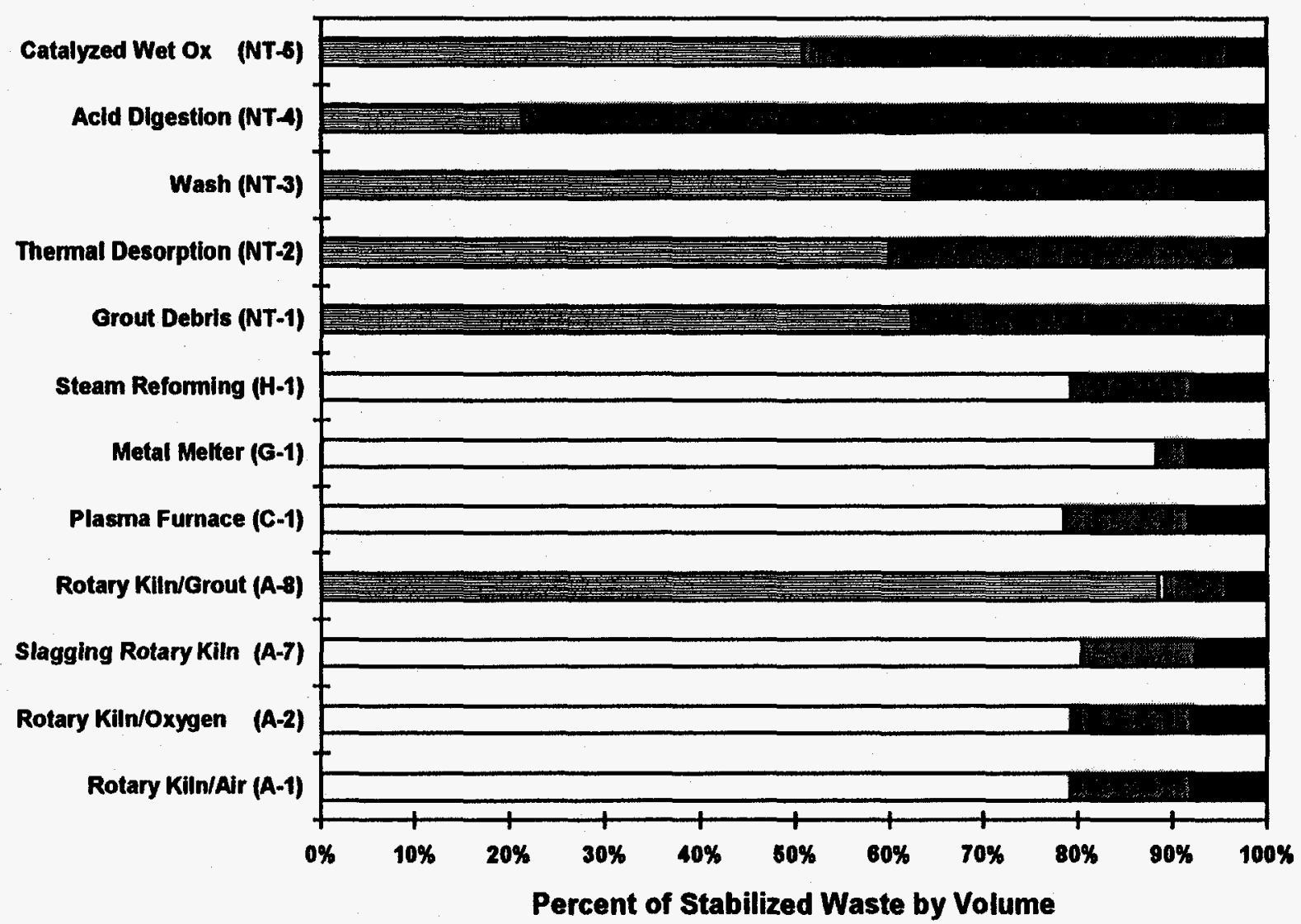

Epecial Waste

a Polyer or Ceramic

口Slag

国Grout

Figure 3-7. Stabilized waste form as a percent by volume of waste sent to disposal for each system. 
The maximum volume reduction for nonthermal systems is approximately 20 to $25 \%$ for Systems NT-4 and NT-5. These systems destroy the combustible debris, converting it to $\mathrm{CO}_{2}$ and water, which decreases the total volume of waste entering the stabilization subsystems but increases the offgas. Systems NT-4 and NT-5 are comparable to System A-8, a rotary kiln that combusts all organic wastes and uses grout as a stabilization agent. System A-8 achieves only a $30 \%$ volume reduction - not much more than Systems NT-4 and NT-5. On the other hand, thermal systems using vitrification for stabilization achieve a volume reduction of about $70 \%$. The output waste volume of all the systems is compared to System A-8 in Table 3-5.

\subsubsection{Metals to Recycle}

One of the concerns of the TSWG is recycling of resources in the treatment facility. Waste metals in the DOE complex may still contain small amounts of radionuclides even after treatment. Therefore, they typically cannot be released to the general public for reuse; however, they may be reusable within the DOE complex. Because of uncertainties in the cost, quality, and value of the recovered metal, no scrap value is assigned or credit taken for the recycled metals, but neither is a disposal cost assigned.

The amount of metal that is decontaminated, either by abrasive blasting or by melting, and recycled is shown in Table 3-3. In the nonthermal systems, lead and other metal items with surface contamination are decontaminated by abrasive blasting and recycled. The lead items that cannot be decontaminated (e.g., lead shot, lead gloves, aprons) are grouted, and ferrous metal debris with internal contamination (e.g., pumps, motors) is also grouted for disposal. Metal drums that have deteriorated to the point that they cannot be decontaminated and recycled are also shredded and grouted. The metal that cannot be decontaminated consists of $5 \mathrm{lbs} / \mathrm{hr}$ of lead items and $149 \mathrm{lbs} / \mathrm{hr}$ of ferrous metal with entrained contamination. The assumption for both thermal and nonthermal systems is that $50 \%$ of the drums can be decontaminated. Thus, for all nonthermal systems, $21 \mathrm{lbs} / \mathrm{hr}$ of lead can be decontaminated by surface cleaning and $462 \mathrm{lbs} / \mathrm{hr}$ of ferrous metal are sent to decontamination, yielding $430 \mathrm{lbs} / \mathrm{hr}$ of clean metal for recycling. The difference of $32 \mathrm{lbs} / \mathrm{hr}$ between contaminated metal input and clean metal output is scale and contaminants that are sent to aqueous waste treatment with the wash water and grit.

In thermal systems, the lead shot, gloves, aprons, etc., are sent to a melter and the resulting ingots are recycled. Thus, $24.5 \mathrm{lbs} / \mathrm{hr}$ of lead is recycled from the thermal systems compared to $21 \mathrm{lbs} / \mathrm{hr}$ from nonthermal systems. All thermal systems except System G-1 (metal melting) receive $468 \mathrm{lbs} / \mathrm{hr}$ of surfacecontaminated ferrous metal that is decontaminated by abrasive blasting to generate $463 \mathrm{lbs} / \mathrm{hr}$ of clean metal for recycling. The rotary kiln systems (A-1, A-2, and A-8) and the steam gasification system (H-1) use a metal melter to treat $149 \mathrm{lbs} / \mathrm{hr}$ of internally-contaminated metal, which includes $50 \%$ of the drums, and generate $134 \mathrm{lbs} / \mathrm{hr}$ of recyclable metal ingots. The slagging rotary kiln does not use a metal melter; rather, internally-contaminated metal is loaded into the kiln, melted, and disposed of with the slag so that only surface-decontaminated metal (i.e., $463 \mathrm{lbs} / \mathrm{hr}$ ) is recycled. The plasma furnace (C-1) is loaded with $149 \mathrm{lbs} / \mathrm{hr}$ of internally-contaminated metal but generates $170 \mathrm{lbs} / \mathrm{hr}$ of recyclable ferrous ingots based on claims by the developers that the metal can be separated from the slag. The extra metal is generated by the reduction of iron oxide in the soil and flyash that is loaded into the plasma furnace for vitrification. All ferrous metal is sent to the metal melter in System G-1, which generates $613 \mathrm{lbs} / \mathrm{hr}$ of ferrous metal ingots for recycling.

Thus, most thermal systems produce more recyclable metals than nonthermal systems, primarily because metal melters are used to treat internally-contaminated metal items and separate the waste into recyclable metal and disposable slag. Metals produced for recycle by thermal and nonthermal systems may retain trace levels of radioactive contamination and, therefore, could not be sold on the open market for 
scrap. They would have no positive asset value. If this metal could be used to fabricate containers for waste disposal, there would be costs for melting, production of plate steel, and fabrication of containers. This cost may or may not be less than the avoided cost of containers fabricated from virgin steel plus disposal which, at the assumed rate of $\$ 243 / \mathrm{ft}^{3}$, ranges from $\$ 17$ million to $\$ 26$ million over 20 years. It should also be noted that the ferrous metal treated by thermal processing (melting) may contain metal contaminants such as copper, beryllium, aluminum, etc. In even small concentrations, such contaminants will make the ferrous metal too brittle to produce steel plate from which waste containers could be fabricated. Thus, the quality of the metal or economics may not justify recycle, and systems such as the plasma and molten metal systems will have no cost advantage over other thermal systems.

\subsection{Final Waste Form}

A TSWG principle is to "minimize effects on human health and the environment." This principle has two subprinciples: 1) minimize exposure now and in the future, and 2) minimize the potential for release of hazardous and radioactive materials from final disposal. Another subprinciple is to "produce stable waste forms for long term storage or disposal." This section attempts to address these principles by comparing the thermal and nonthermal final waste forms sent to the disposal site. The waste from all systems studied will be disposed of in the same engineered disposal facility. Thus, the issue is the relative performance and stability of the different waste forms generated by the various thermal and nonthermal systems.

For disposal of toxic metals, such as lead, mercury, cadmium, barium, arsenic, silver, and chromium, the EPA requirements include passing the toxic characteristic leach procedure (TCLP) leach tests defined by the EPA. These tests assess the current performance of the waste form, not its long-term stability. However, toxic metals are toxic forever while the waste form may, over time, deteriorate. DOE requires that radionuclides do not migrate to water supplies nor create significant direct radiological risks. DOE regulations for nuclear materials disposal require analyzing the effectiveness of the waste form and the disposal site for the duration of the potential risk to the public. However, it is difficult to demonstrate the behavior of waste forms and disposal sites over the life of radionuclides that may present hazards for thousands of years. Thus, although several promising waste forms are available to stabilize solid wastes, their ability to immobilize inorganic contaminants over the long term has not been demonstrated.

There are two types of waste forms:

- Encapsulants, which surround the waste residue with another material that keeps the waste from migrating. Encapsulating materials may or may not react chemically with the residue. These materials may be used as micro-encapsulants, surrounding small particles of waste such as salt or sludge particles, or macro-encapsulants, surrounding large items such as debris.

- Solvents, which dissolve the waste material at elevated temperatures and form rock-like or glassy materials upon cooling.

These waste forms protect the public by immobilizing contaminants within an inert matrix and preventing the contaminants from leaching out into the groundwater or surface water.

The nuclear industry has investigated a wide variety of final waste forms over the past 25 years. The waste forms used in the ITTS and INTS studies span the characteristics of the proposed waste forms to determine their effect on processing and disposal costs. These waste forms include grouts, polymers, 
phosphate-bonded ceramic, and slag or glass. Although the long term performance of these waste forms cannot be quantified for comparison in a paper study, some qualitative statements and comparisons can be made.

Grout is a well-known material that has been used extensively to solidify ash from incinerators and to stabilize sludge. Encapsulation in grout is an ambient temperature process that is low in cost and uses low cost materials. However, problems regarding compressive strength, stability, and leach resistance can occur without good process controls. Cement grout has an open cell structure that becomes porous (approximately 25 to $75 \%$ porosity) as the cement sets and cures so that water may permeate its surface, increasing the potential for leaching. High concentrations of salt or boron oxide interfere with setting of Portland cement. Grout increases waste volume as discussed previously. A mass ratio of 2:1 of grout to waste was used in the ITTS and INTS studies; however, a ratio of 4:1 may be required for some wastes, which would produce higher disposal volumes and disposal costs. Grout also has a relatively short lifetime, but the lifetime for grout disposed and covered tightly by sealants, either organic or compacted clay, is not known. The degradation of concrete in the environment involves attack by brine or structural change due to adsorption of carbon dioxide; both can be avoided in a controlled disposal environment.

Polyethylene (or polymer) has been under development at Brookhaven National Laboratory for the past several years. It is used to stabilize soluble salts that may leach from the relatively porous grout or phosphate-bonded ceramic, and salts that may decrease the performance of glass or that may volatilize in the vitrifier. Polyethylene encapsulation is a slightly elevated temperature process that uses moderately complex extrusion equipment and moderately priced material. The waste residues must be dry. Polyethylene is inert to most waste residues, very resistant to radiation, and allows relatively high waste loadings for soils, salts, and ash ( 50 to $70 \%$ by weight). Due to these higher loadings but lower density, the volume increase is about the same as grout and, therefore, the disposal costs are similar. However, the life of polyethylene waste forms in a disposal environment is unknown, although it is expected to be greater than the life of grout.

Phosphate-bonded ceramic, which is being developed at Argonne National Laboratory, is a fastsetting ceramic material produced at low temperature. The manufacturing and mixing process uses simple equipment similar to that used in producing grouted waste. The material has a high compressive strength, forms a chemical bond with metals, and allows a high waste loading ( 50 to $70 \%$ by weight) of ash, process residues, and insoluble salts. Its porosity is less than that of grout (approximately 8\%), but greater than that of polymer, so its use for stabilization of soluble salts may not be advisable. There have been no commercial applications of phosphate-bonded ceramic as a final waste form, but it should be a low-cost process.

Borosilicate glass (BSG) has been used in Europe, Japan, and the United States for immobilization of high-level waste. High temperatures $\left(\sim 1920^{\circ} \mathrm{F}\right)$ are used to make a solution of waste and additives with the required composition to form BSG. Application to MLLW is technically feasible, and DOE has been developing such a process during the last several years. However, with widely varying wastes, detailed waste characterization may be required and process control to form an adequate glass may be difficult. BSG has a very long lifetime, excellent leach behavior, and may decrease MLLW volume.

Iron-enriched basalt (IEB) is a high performance glass/ceramic waste form originally developed at INEL in the 1970s. It was the basis for the ITTS vitrification processes. Recently, substantial work has been performed at Argonne National laboratory and Pacific Northwest Laboratory on glassy slags, essentially the same material as IEB. This material is similar to the mineral comprising the central mountains of Idaho (basalt) and has an extremely long lifetime (millions of years). The process requires a 
very high temperature $\left(>2900^{\circ} \mathrm{F}\right)$ and has the potential for higher waste loadings than BSG. However, there is no commercial experience with this material.

In summary, the vitrified waste forms have very long lifetimes, high waste loadings, and lower disposal volumes than nonthermal waste forms. These materials are not porous and are expected to immobilize the waste and associated contaminants for an extremely long period of time, thereby providing high performance at relatively low disposal cost. However, they are more difficult to produce, and high temperature processes require good air pollution control systems to capture volatilized materials. Polyethylene appears to be an excellent waste form for waste salts that cannot be incorporated into a glass or glass/ceramic. Grout has the highest life-cycle cost and is expected to be the lowest performer; it is expected to have the shortest lifetime and release the contained contaminants most rapidly. Relative to vitrified waste forms, grout and polyethylene increase the total volume of the final waste form, increase the disposal cost, and increase the land used for disposal.

\subsection{Contaminant Destruction and Removal Performance}

In this section, the performance of the thermal and nonthermal systems is compared with respect to the destruction and removal efficiencies that the various technologies could be expected to achieve, and with respect to the contaminants that might be expected in the effluent streams. This section addresses the TSWG principles "minimize effluent" and "minimize effects on human health and the environment," as well as the subprinciple "minimize exposure now and in the future."

It should be understood that the performance factors are highly uncertain and depend on the contaminants, the matrix containing the contaminants, residence time in the treatment process, and operating conditions. The only way to quantitatively evaluate system performance is to perform treatability studies, or the equivalent of test runs, on the waste to be treated and under the expected operating conditions. The destruction efficiencies and removal efficiencies quoted are based on vendor data from tests on various organic contaminants and matrices under specific operating conditions.

\subsubsection{Thermal Treatment Systems}

A thermal treatment process includes the main thermal treatment unit (i.e., incinerator, plasma furnace, metal melter, steam gasifier, or vitrifier), secondary combustion chamber (SCC), and the air pollution control system (APC). Incinerators must meet the destruction and removal efficiency (DRE) requirements for organic contaminants on the combustible and noncombustible matrices. They are required by regulation to demonstrate ${ }^{\mathbf{a}} 99.99 \%$ DRE for most Resource Conservation and Recovery Act (RCRA) organic contaminants and $99.9999 \%$ DRE for dioxin-listed RCRA waste and Toxic Substances Control Act organic contaminants. The other thermal treatment systems, although expected to be regulated as miscellaneous thermal treatment units, will most likely be required to meet the same DRE criteria. DRE refers to the total system capability to destroy and remove the organics from the waste stream and so is based on measurements of the contaminants on incoming waste and the contaminants in the offgas effluent.

a The DRE must be demonstrated in trial burns on the waste to be treated before the thermal treatment system can be put into operation. 
Thus, the performance of a main thermal treatment unit cannot be separated from the performance of the SCC and the APC systems.

Although thermal processes are very efficient at destroying organics, they release volatile metals (and their compounds) and radionuclides. In addition, dioxins, furans, and products of incomplete combustion may be produced. Thus, a high-performance APC system with built-in redundancy is required to reduce the potential for release to the environment.

As indicated in Section 1, one of the reasons for studying nonthermal systems is the concern over toxic emissions, such as dioxins and furans, from thermal systems. Many factors contribute to dioxin and furan formation, including the type of contaminants and presence of precursors, characteristics of the offgas from the thermal treatment unit, and the design of the air pollution control system.

In an oxygen environment, many factors contribute to the production of dioxins and furans. Certain chlorinated hydrocarbons (particularly aromatic hydrocarbons) are defined by the EPA as dioxin/furan precursors and these may be part of the feed stream. Dioxins and furans can also be produced when hydrocarbons are oxidized in the presence of chlorine or hydrochloric acid, or chlorinated hydrocarbons are oxidized under conditions such that dioxin or furan precursors are formed. If chlorinated hydrocarbons are oxidized under conditions where complete mixing with oxygen occurs and sufficient residence time is available so that every molecule is subjected to a temperature greater than $871^{\circ} \mathrm{C}$, then precursors will not form and precursors in the feed stream will be destroyed. However, in some thermal oxidation processes there is the potential for some molecules to be outside the high temperature zone, or to be insufficiently mixed with oxygen so that complete oxidation does not take place, thereby allowing precursors to form and pass through to the APC system. In this case, if sufficient time elapses during cooling of the offgas from the main thermal treatment unit, the precursors may recombine on the surface of particulates in the gas stream to produce dioxins or furans. Recent studies indicate that dioxin/furan formation occurs during cooldown through a temperature range of about $350^{\circ} \mathrm{C}$ to $250^{\circ} \mathrm{C}$.

A well-designed thermal oxidation system and air pollution control system can minimize or avoid the production and/or release of dioxins or furans by proper reaction chamber design, which promotes mixing and adequate residence time, secondary combustion to oxidize any remaining organic compounds in the offgas, rapid cooldown to minimize recombination of precursors, filtration of particulates to remove recombination sites, and scrubbing to remove hydrochloric acid prior to discharge to the stack. The proposed thermal systems and the APC subsystems are designed to meet the required DRE and reduce organic contaminants and volatile metals and metal compounds by a factor of ten below regulatory emission standards.

\subsubsection{Nonthermal Treatment Systems}

Nonthermal systems have the potential of lower emission of toxic contaminants in the offgas than thermal systems. By using chemical oxidation processes there is less offgas that might carry over toxic materials, and by operating at a low temperature it is assumed there would be fewer organic by-products, including dioxins and furans, and volatilized metals in the offgas. For these studies, the upper temperature limit for nonthermal processes was taken as $350^{\circ} \mathrm{C}$. However, there are some high temperature destruction technologies that do not generate recombination products (dioxins/furans) in an offgas. Such high temperature technologies include those that oxidize organic matter in a water medium (e.g., wet air oxidation and supercritical water oxidation), though they still have the potential of producing dioxins in the aqueous phase. Reduction processes that operate in an oxygen deficient atmosphere, such as steam reforming, typically have less tendency to produce dioxins/furans in the offgas if hydrochloric acid and 
particulates are removed prior to oxidizing the syngas in the APC system. However, the amount of dioxins/furans in the offgas of such high temperature reduction technologies must be established, and such technologies may still volatilize heavy metals and radionuclides.

Dioxins and furans can also form in aqueous-based oxidation processes similar to those discussed below, depending on the presence of dioxin/furan precursors, and remain in the aqueous phase. Formation of dioxins has been observed in aqueous systems under conditions of aggressive chlorination in the presence of aromatic hydrocarbons. Examples include bleaching of wood pulp with $\mathrm{Cl}_{2}$ and use of hypochlorite for disinfection of water containing phenol. Dioxins may also form under slow aqueous phase destruction of aromatic organochlorides through free-radical mechanisms where recombination is possible. Although dioxins and furans may form in the aqueous phase, they have not been reported in the test data for the alternative technologies surveyed. Whether this is an oversight and measurements have not been made, or they are not present in measurable quantities, is unknown at this time. Dioxins and furans have limited solubility in water and are solids at room temperature. They may be more easily controlled in the aqueous phase than in the gas phase, and subsequently removed or destroyed by a post-treatment process. The Universal Treatment Standards for these compounds in wastewaters are $0.063 \mathrm{ng} / \mathrm{L}$ for dioxins and 0.035 $\mathrm{ng} / \mathrm{L}$ for furans; the ability to achieve these levels when these compounds are present has not been demonstrated.

The regulatory requirements for nonthermal processes or systems have not been defined in terms of DRE, and destruction of the organic compounds in the MLLW to meet EPA's Universal Treatment Standards (UTS) is uncertain. However, the nonthermal systems considered here have been conceptually designed to achieve the same destruction levels required of thermal systems. Because of the low temperatures involved, volatilization of heavy metals (except for mercury) and radionuclides is not a significant problem in nonthermal systems.

To treat solid waste using nonthermal technologies, the organic material must be removed from the solid matrices before it can be destroyed by chemical oxidation processes. Following separation, the remaining solids are stabilized for disposal. The separation processes are discussed next, followed by chemical oxidation processes.

\subsubsection{Separation}

Vacuum Thermal Desorption. The low-temperature vacuum thermal desorption process operates at pressures as low as $0.5 \mathrm{psia}$, and inorganic waste may be heated to $350^{\circ} \mathrm{C}\left(660^{\circ} \mathrm{F}\right)$. The temperature of organic waste, such as soft debris, is limited to $200^{\circ} \mathrm{C}\left(390^{\circ} \mathrm{F}\right)$ or less to prevent melting of plastics that may be in the waste. An inert nitrogen atmosphere is used to prevent oxidation of organics or combustible waste. Reported removal efficiencies for volatile organic contaminants from soils, soils containing clay, and debris range from 94 to $99.99 \%$, depending on the volatility of the contaminant, the characteristics of the solid particles or surface containing the organic, the desorption temperature, and the residence time of the waste within the desorber. These removal efficiencies imply that the stabilized solid waste may contain up to $6 \%$ of the original organic contaminants entering the desorber. Thus, if the soil or debris entering the desorber contained $100 \mathrm{ppm}$ of organic contaminants, then the treated waste entering the grouting system would contain $10 \mathrm{ppb}$ to $6 \mathrm{ppm}$ organic contaminants.

In addition to vaporization of organic contaminants, mercury and several of its compounds will be vaporized and subsequently condensed for either amalgamation or treatment in the aqueous waste subsystem. Trace levels of mercury may remain in the solid matrices, so a mercury removal process following the desorption process has been included. This mercury removal process is discussed in 
Section 3.5. The nonvolatile metals and radionuclides remain with the solid wastes and are stabilized with the soil and debris in grout, or with the sludges in polymer.

Washing. Three different washing processes are used in the nonthermal treatment systems to remove organic contaminants and soluble inorganic contaminants from solid waste matrices (i.e., soils, sludges, and soft and open debris). These washing processes and the reported organic removal efficiencies are as follows:

- Soil washing

- Up to $99.8 \%$ removal of organics from soils

- No data are available for the extent of removal of organics from sludges as this application of the washing process has not been adequately tested. Based on vendor claims, it was assumed that washing could achieve a degree of contaminant removal equivalent to that achieved for soils.

- Agitation wash for soft debris - 90 to $99.9 \%$ removal of organic contaminant

- High pressure spray washing of open debris - 80 to $99.9 \%$ removal of organic contaminants.

The percent of organic and inorganic material removed by washing depends on the nature of the contaminant, the properties of the waste material surface or particles to which the contaminant adheres, the type of surfactant used to solubilize and remove the organic material, the residence time or number of wash cycles, and the operating conditions (temperature and $\mathrm{pH}$ of the wash solution, spray pressure to dislodge particles and scale from the surfaces, etc.). Removal of metals and radionuclides depends on the solubility of the compounds in the wash solution and the ability of mechanical washing forces to remove particulates. No special agents to solubilize and remove these inorganic contaminants were considered in the INTS study. For the purposes of the INTS study, it was assumed that insoluble compounds remaining on the solid wastes after washing would be adequately stabilized with the solid matrix in either grout or polymer.

Depending on the concentration of organic material in the wash water, the discharge from the washing subsystem is sent to either the aqueous waste treatment subsystem ( $\leq 1 \%$ organic matter) or the organic destruction subsystem, where the organic contaminants are oxidized. The treated solids sent to stabilization will retain the insoluble metals and radionuclides, soils will retain up to $1 \%$ of the organic material that initially entered the washing process, soft debris will retain 0.1 to $10 \%$ of the organics, and open debris will retain 0.1 to $20 \%$ of the organics. Thus, for solid matrices containing 100 ppm organic contamination, the washed solids may contain the following:

- Soil - 1 ppm organic contaminants or less

- Soft debris -0.1 to 10 ppm organic contaminants

- Open debris -0.1 to 20 ppm organic contaminants. 


\subsubsection{Organic Destruction}

Three types of chemical oxidation processes are used in the nonthermal systems to treat organic, or combustible, wastes and convert the organic material to nonhazardous compounds. These processes receive organic wastes (organic liquids, organic sludges, and combustible or soft debris [Systems NT-4 and NT-5]) and organic waste generated internally (e.g., condensate from the thermal desorber and organic liquids separated from the aqueous waste stream). The reported destruction efficiencies for these processes depend on the organic material being destroyed in the tests for which data was collected, the operating conditions (temperature and pressure), and the residence time of the waste in the reaction vessel. In chemical oxidation processes, the destruction rate and efficiency depend on the surface area of the particle or liquid to be destroyed; thus, smaller particles of organic waste, or soluble organic liquids, will react faster and more completely than larger particles or immiscible liquids. Residence time and the ability of the acid solution to continually contact fresh surfaces of the waste material are also factors in achieving high destruction efficiencies. By operating these processes in a closed-batch mode with continuous turbulent flow and recirculation, the organics may be completely destroyed over time.

In the following discussion the term "absolute destruction efficiency" refers to the complete conversion of the organic species on which tests were performed to carbon dioxide and water. The term "destruction efficiency" refers to conversion of the organic species of interest to $\mathrm{CO}_{2}$ and water plus several intermediate reaction byproducts that may or may not be hazardous. Developers of these chemical oxidation technologies have reported the following:

- Mediated Electrochemical Oxidation - absolute destruction efficiencies of 96 to $99.8 \%$

- Catalyzed Wet Oxidation - absolute destruction efficiencies of 99 to $99.96 \%$

- $\quad$ Acid Digestion - destruction efficiencies of 95 to $97 \%$.

As shown in Figure 3-8, assuming a concentration of organic waste in the reaction vessel of $1 \%$ $(10,000 \mathrm{ppm})$ for a sufficient length of time to achieve the above destruction efficiencies, and that a side stream of the acid solutions is removed, neutralized, and sent to aqueous waste treatment, then the aqueous effluent will contain organic concentrations as follows:

- Mediated Electrochemical Oxidation -160 to $0.01 \mathrm{ppb}$

- Catalyzed Wet Oxidation -40 to $0.002 \mathrm{ppb}$

- Acid Digestion - 200 to $0.15 \mathrm{ppb}$.

This assumes a total destruction and removal efficiency of the UV photooxidation unit combined with the activated carbon filter of $99.96 \%$ to $99.99995 \%$. Thus, $2 \times 10^{-5}$ to $2 \times 10^{-10}$ times the amount of organic material entering the chemical oxidation process will be discharged with the wastewater, depending on the contaminant and the technology. 

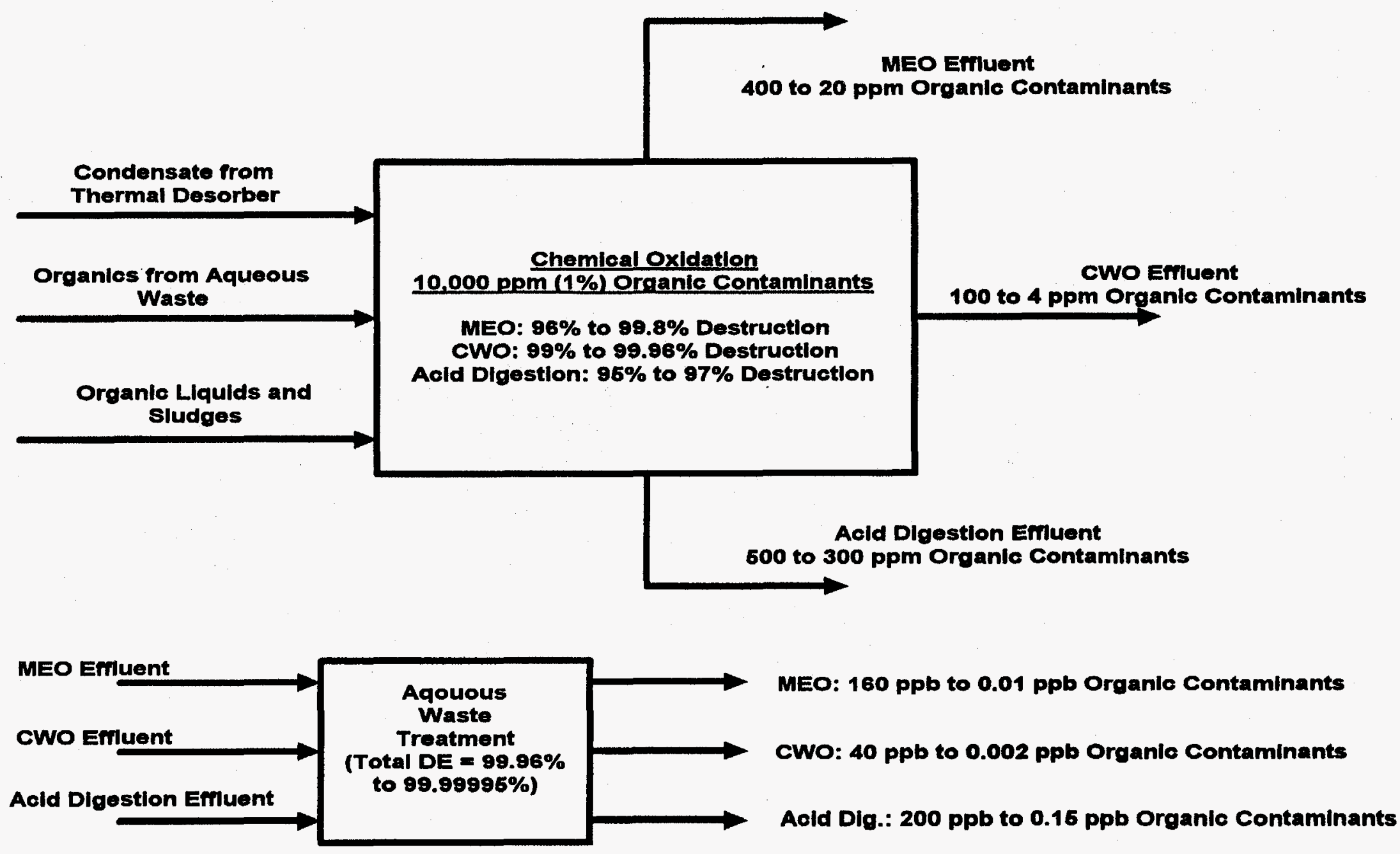

Figure 3-8. Organic destruction efficiencies for the chemical oxidation processes combined with aqueous waste treatment. 


\subsubsection{Aqueous Waste Treatment}

The aqueous waste treatment subsystems for both thermal and nonthermal systems are essentially identical in design and vary only in size and capacity. The first step in aqueous waste treatment is removal of soluble and insoluble material. Phase separation is used to remove and concentrate immiscible organics, which are sent to the thermal treatment or the organic destruction subsystems. Heavy metals and radionuclides are precipitated and suspended solids are removed by filtration and/or centrifuging. In both the ITTS and INTS studies it was assumed that the resulting water will be sufficiently clear for the UV photooxidation process to efficiently destroy the remaining soluble organic material.

The reported destruction efficiencies for UV photooxidation range from 60 to $99.95 \%$, depending on the contaminant and residence times. Some vendors use catalysts with hydrogen peroxide $\left(\mathrm{H}_{2} \mathrm{O}_{2}\right)$ or ozone $\left(\mathrm{O}_{3}\right)$ to increase the performance for selected contaminants. Ozone, which is bubbled through the water, may carry some volatile organic contaminants to the ozone destruction unit; however, volatile organics have been reported to be destroyed to nondetection levels in this unit. After treatment in the UV photooxidation unit, the wastewater passes through an activated carbon bed that removes remaining trace organic contaminants with a $99.9 \%$ efficiency. Thus, the water effluent from thermal or nonthermal systems will have $4 \times 10^{-4}$ to $5 \times 10^{-8}$ times the input concentration of organic contaminants. That is, assuming the concentration of organics in the wastewater entering the aqueous treatment subsystem is at its maximum level of $1 \%$ (i.e., $10,000 \mathrm{ppm}$ ), then the output concentration will be $4 \mathrm{ppm}$ to $0.5 \mathrm{ppb}$. This is shown graphically in Figure 3-9.

The dissolved metals and radionuclide salts are precipitated and filtered out of solution and subsequently stabilized in polymer. The minimum concentration level that can be achieved by precipitation is the solubility limit of the particular compound. No compound is completely insoluble, so there will be some minimum level of metal and radionuclide salts remaining in solution that depends on the temperature, $\mathrm{pH}$, and anion composition of the solution. The solubility limit for metal sulfides is approximately 0.001 $\mathrm{ppb}$, and for hydroxides is approximately $10 \mathrm{ppb}$, depending on the metal. Thus, media beds, such as ion exchange resins, are used to remove the trace levels of metals remaining after precipitation. Ion exchange resins have demonstrated removal efficiencies for metals of 90 to near $100 \%$, depending on the metals and type of resin. A series of ion exchange beds with different resins may be used for selective removal of the inorganic contaminants in the waste. Other media bed materials, such as ferrites, have demonstrated up to $\mathbf{9 9 . 9 9 9 \%}$ removal of RCRA metals and $\mathbf{9 9 . 9 8 6 \%}$ removal of plutonium ions from waste waters.

Contaminants that may occur in the aqueous waste, and the design features used to oxidize and/or remove the contaminants before the water exits the treatment subsystem, are shown in Table 3-7 for thermal and nonthermal systems.

\subsubsection{Air Pollution Control Systems}

The thermal systems have up to four separate APC systems for each of the following subsystems: main thermal treatment, vitrifier, metal melter, and mercury and lead treatment. The thermal APC systems are designed to remove organic contaminants, particulates, heavy metals, and radionuclides to meet the emission standards. The APC systems in the ITTS study were designed to reduce the emissions of nonmetals below the EPA limits, and to reduce the emission of metals by a factor of 10 below the EPA limits. Sulfur-impregnated carbon filters are used to capture and immobilize trace levels of mercury vapors; these filters can remove approximately $99 \%$ of the mercury vapors entering the filters if the gas 
Aqueous Waste $<1 \%$ Organic (<10,000 ppm) Contaminant Content

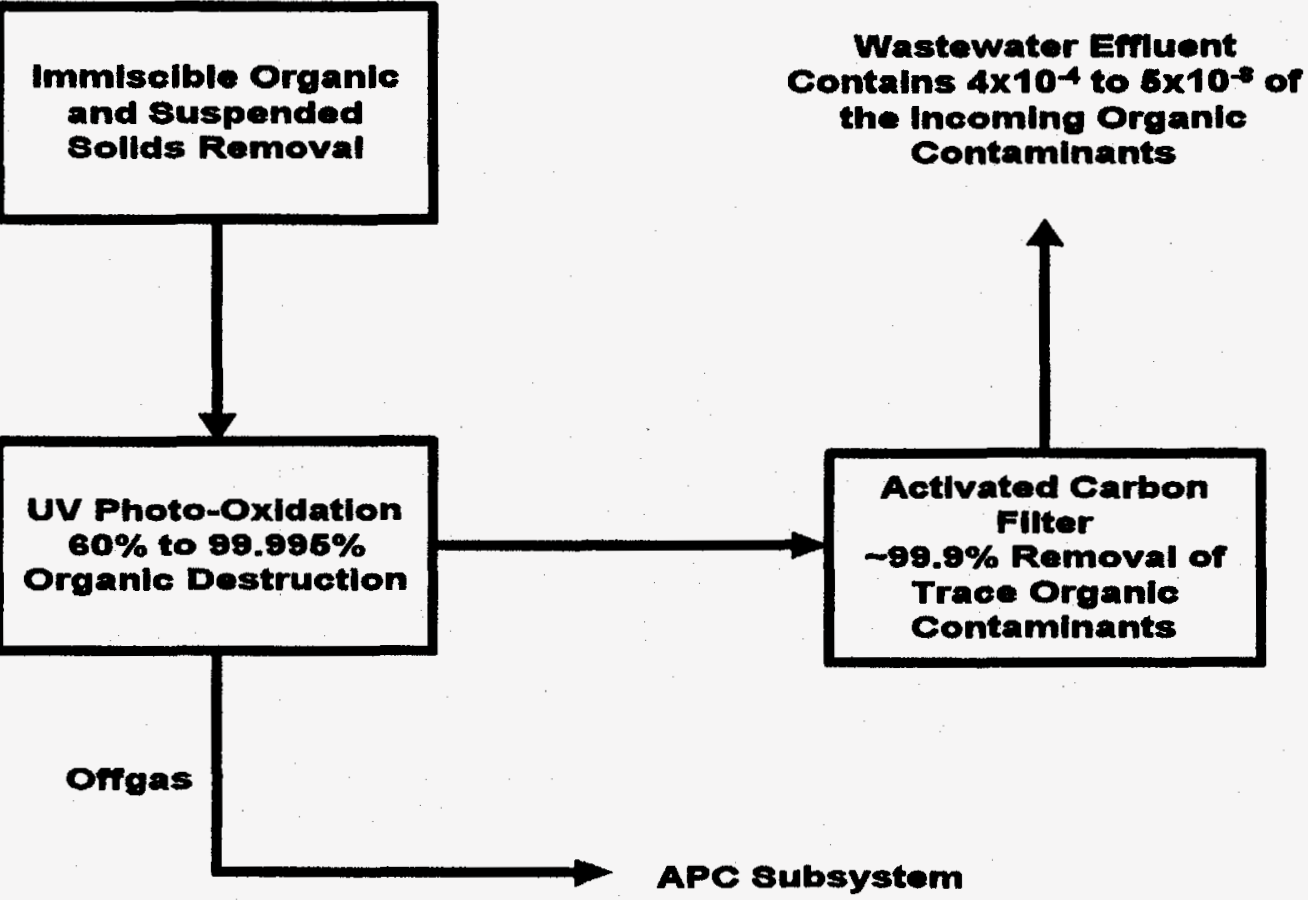

Figure 3-9. Organic destruction and removal efficiencies for the aqueous waste treatment subsystem. 
Table 3-7. Potential contaminants in the aqueous waste and mitigating design features.

\begin{tabular}{|c|c|c|c|}
\hline \multicolumn{2}{|c|}{ Thermal Systems } & \multicolumn{2}{|c|}{ Nonthermal Systems } \\
\hline Contaminants & Design Features & Contaminants & Design Features \\
\hline $\begin{array}{l}\text { Organic contaminants, } \\
\text { including reaction } \\
\text { byproducts }\end{array}$ & $\begin{array}{l}\text { Phase separation } \\
\text { UV Photooxidation } \\
\text { Activated Carbon }\end{array}$ & $\begin{array}{l}\text { Organic contaminants, } \\
\text { including reaction } \\
\text { byproducts }\end{array}$ & $\begin{array}{l}\text { Phase Separation } \\
\text { UV Photooxidation } \\
\text { Activated Carbon }\end{array}$ \\
\hline \multirow[t]{2}{*}{$\begin{array}{l}\text { Heavy metals and } \\
\text { radionuclides }\end{array}$} & $\begin{array}{l}\text { Neutralization } \\
\text { Precipitation } \\
\text { Filtration } \\
\text { Centrifuge } \\
\text { Ion Exchange }\end{array}$ & $\begin{array}{l}\text { Heavy metals and } \\
\text { radionuclides }\end{array}$ & $\begin{array}{l}\text { Neutralization } \\
\text { Precipitation } \\
\text { Filtration } \\
\text { Centrifuge } \\
\text { Ion Exchange }\end{array}$ \\
\hline & & $\begin{array}{l}\text { Trace levels of } \\
\text { dioxins }\end{array}$ & $\begin{array}{l}\text { UV Photooxidation } \\
\text { Activated Carbon }\end{array}$ \\
\hline
\end{tabular}

a. Note that the potential for dioxins in the aqueous waste of nonthermal systems arises from the use of free-radical reactions in the nonthermal oxidation processes and the presence of chlorinated hydrocarbons in the waste. It is unlikely that dioxins will be found in the offgas from nonthermal systems due to their low operating temperature. The presence of dioxins in the chemical solutions, although possible, has not been confirmed.

stream is cooled to $200^{\circ} \mathrm{F}$ or less. Conservative removal efficiencies for units used in thermal APC subsystems are shown in Figure 3-10. Regulatory emission limits and the emission levels used to design the ITTS systems for nonmetals and metals are listed in References 2 and 4.

The components of thermal and nonthermal APC systems are similar and perform similar functions as shown in Table 3-8, which indicates the contaminants that may be in the offgas entering the APC and the design features used to remove these contaminants from the gas stream. However, because approximately an order of magnitude more nontoxic gases are emitted from the thermal system (7000 to $26,000 \mathrm{lbs} / \mathrm{hr}$ ) than from nonthermal systems $(700 \mathrm{to} 1400 \mathrm{lbs} / \mathrm{hr})$, more fume, particulates, and contaminants may be carried over with the offgas from the thermal systems. Thus, the APC system for thermal systems must be much larger and more effective than that for nonthermal systems to achieve the same level of performance.

The components of the nonthermal offgas system are shown in Figure 3-11. The several condensers in the system will remove over $95 \%$ of the vaporized organics, water vapor, $\mathrm{HCl}$, and mercury. The metal and HEPA filters remove the particulates arising from thermal desorption and condensed mercury particles that are carried with the gas stream. The gas phase corona reactor plays a role similar to the secondary combustion chamber in the thermal systems by oxidizing the trace organic material remaining in the offgas. The acid gas scrubber removes any remaining acid gases and the activated carbon removes remaining trace organics. Trace levels of mercury vapor are removed from the gas stream by sulfur-impregnated carbon, and the final HEPA filter removes any remaining particulates that may contain radionuclides or heavy metals. The concentration of organic matter or radionuclides cannot be determined because oxygen is added to the gas stream in the corona reactor to assist in the oxidation process, and water vapor is added in the acid gas scrubber. However, the contaminants in the offgas will be decreased by four to eight orders of magnitude before the gas is discharged to the stack. 


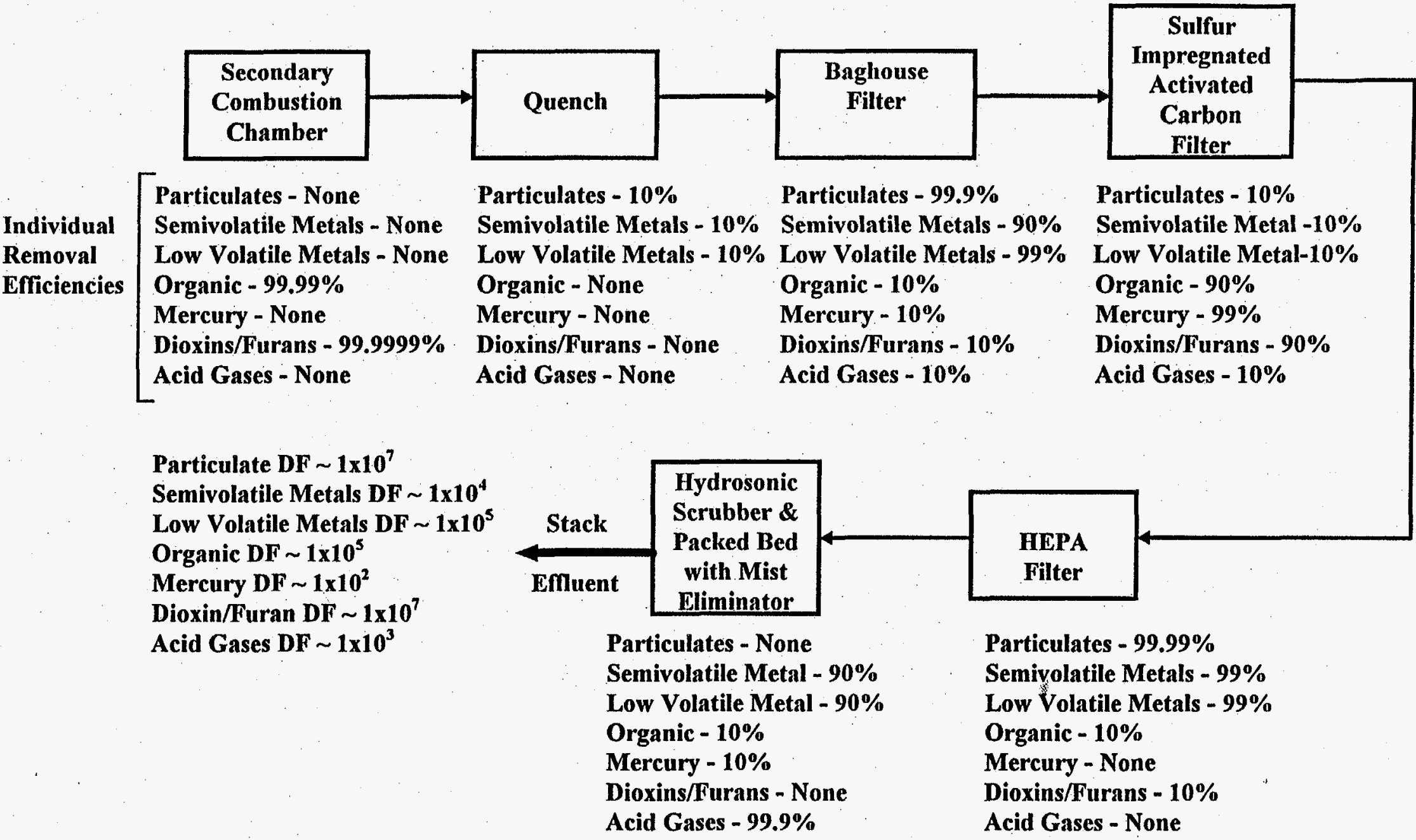

DF = Decontamination Factor, the ratio of initial pollutant levels divided by the final (stack) pollutant level.

Figure 3-10. Conservative estimate of destruction and removal efficiencies at each stage of treatment for a typical air pollution control subsystem for mixed waste thermal treatment. 
Table 3-8. Potential contaminants in the primary treatment system offgas and design features to minimize release to the environment

\begin{tabular}{|c|c|c|c|}
\hline \multicolumn{2}{|c|}{ Thermal Systems } & \multicolumn{2}{|c|}{ Nonthermal Systems } \\
\hline $\begin{array}{c}\text { Potential } \\
\text { Contaminants }\end{array}$ & Design Features & $\begin{array}{c}\text { Potential } \\
\text { Contaminants }\end{array}$ & Design Features \\
\hline $\begin{array}{l}\text { Dioxins, furans, and } \\
\text { PICs }\end{array}$ & $\begin{array}{l}\text { - Secondary } \\
\text { combustion } \\
\text { chamber }\end{array}$ & $\begin{array}{l}\text { Volatile organics and } \\
\text { products of } \\
\text { incomplete reaction. }\end{array}$ & $\begin{array}{l}\text { - Condensers } \\
\text { - Corona reactor }\end{array}$ \\
\hline $\begin{array}{l}\text { Volatilized heavy } \\
\text { metals, entrained } \\
\text { particulates, and } \\
\text { radionuclides }\end{array}$ & $\begin{array}{l}\text { - Quench coolers } \\
\text { - Baghouse filter }\end{array}$ & $\begin{array}{l}\text { Volatilized heavy } \\
\text { metals, entrained } \\
\text { particulates, and } \\
\text { radionuclides }\end{array}$ & $\begin{array}{l}\text { - Condensers } \\
\text { - Sintered metal } \\
\text { filters }\end{array}$ \\
\hline $\begin{array}{l}\text { Small particulates } \\
\text { passing through the } \\
\text { baghouse }\end{array}$ & - HEPA filters & $\begin{array}{l}\text { Particulates that pass } \\
\text { through the metal } \\
\text { filter }\end{array}$ & - HEPA filters \\
\hline $\begin{array}{l}\text { Acid gases and } \\
\text { particulates passing } \\
\text { through the HEPA } \\
\text { filters }\end{array}$ & $\begin{array}{l}\text { Hydrosonic } \\
\text { scrubber }\end{array}$ & $\begin{array}{l}\text { Acid gases and } \\
\text { particulates passing } \\
\text { through the HEPA } \\
\text { filters }\end{array}$ & - Scrubbers \\
\hline Nitrogen oxides & $\begin{array}{l}\text { - } \mathrm{NO}_{\mathrm{x}} \text { abatement } \\
\text { devices }\end{array}$ & Nitrogen oxides & $\begin{array}{l}\text { - Ammonia } \\
\text { conversion to } \\
\text { nitrogen }\end{array}$ \\
\hline Trace organics & $\begin{array}{l}\text { - Activated carbon } \\
\text { filters }\end{array}$ & Trace organics & $\begin{array}{l}\text { - Activated carbon } \\
\text { filters }\end{array}$ \\
\hline Mercury vapors & $\begin{array}{l}\text { Sulfur } \\
\text { impregnated } \\
\text { carbon filters }\end{array}$ & Mercury vapors & $\begin{array}{l}\text { - Condensers } \\
\text { - Sulfur- } \\
\text { impregnated } \\
\text { carbon filters }\end{array}$ \\
\hline
\end{tabular}




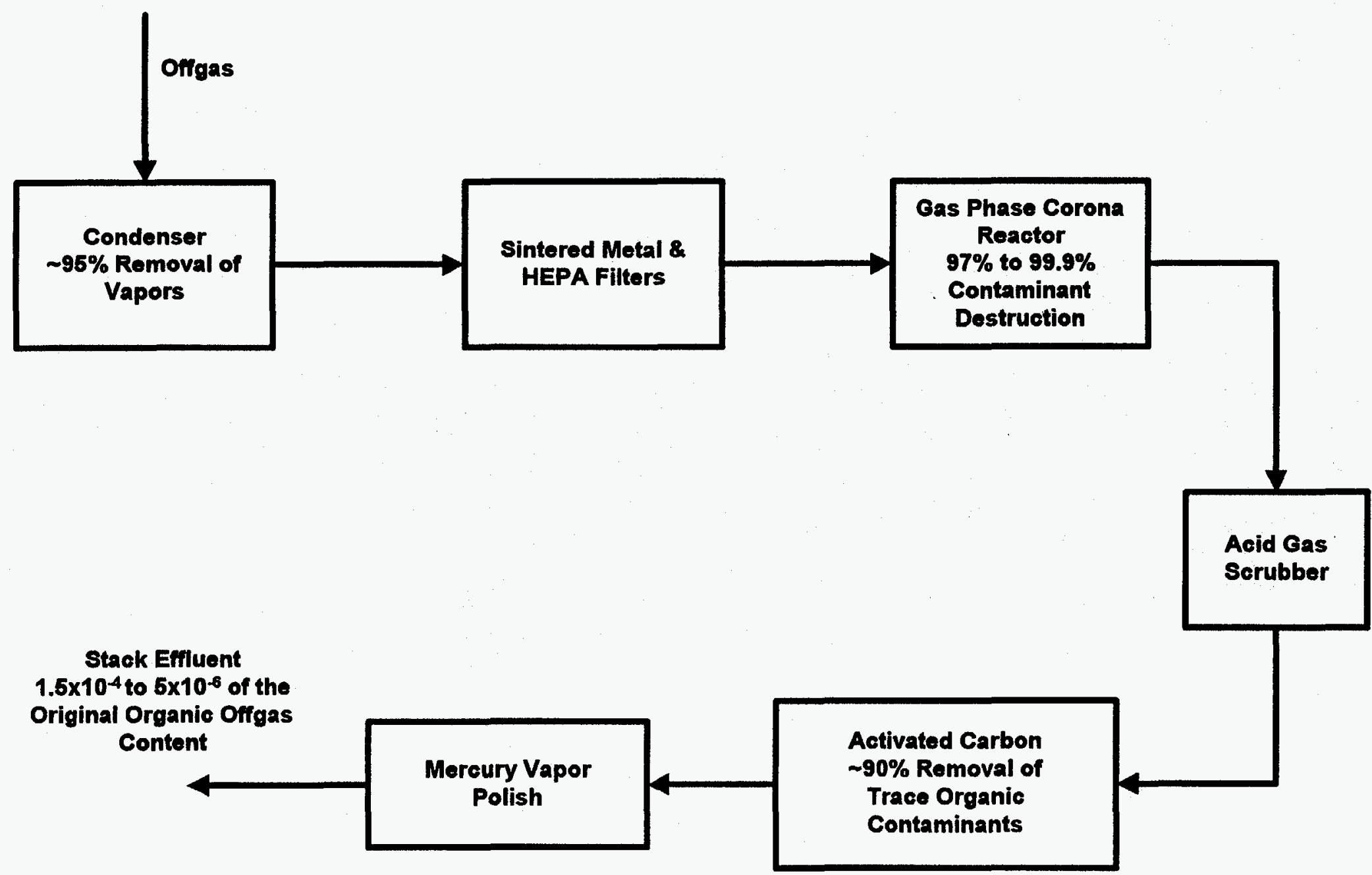

Figure 3-11. Organic destruction and removal efficiencies for a typical nonthermal air pollution control subsystem. 
Thus, the thermal and nonthermal treatment systems contain redundant unit operations designed to meet or exceed the regulatory standards for air emissions. Organic contaminants will be converted to $\mathrm{CO}_{2}$ and water to the prescribed levels, and heavy metals and radionuclides will be collected in the APC system or remain with the solid waste matrices and subsequently be immobilized in a final waste form.

\subsubsection{Stabilization}

Because of the high DRE of the thermal treatment process and the high temperatures of the vitrification process, no organic contaminants will survive these treatment processes. Most metals and radionuclides will be incorporated into the glass or slag. Volatile metals (mercury and cadmium) that are captured in the vitrifier's APC system will be stabilized in polymer. Salts removed from the offgas by the scrubber and subsequently precipitated in the aqueous waste treatment system are also stabilized in polymer. Mercury will be captured and amalgamated for disposal as discussed in Section 3.5.

In nonthermal systems, a significant amount of organic material may remain with the solid matrices and subsequently be stabilized in grout or polymer. Thermally desorbed solid waste may retain up to $6 \%$ of the organic contaminants entering the desorber, and washed solid waste may retain 0.1 to $20 \%$ of the organic contaminants entering the wash system. The long-term stability of grout or polymer with these levels of organic contaminants is uncertain. The majority of the heavy metals and radionuclides will remain with the solid waste streams and be stabilized with the treated solids. The inorganic contaminants that are removed from the solids are collected in the APC filters or precipitated from wastewaters and are subsequently stabilized in polymer.

\subsubsection{Summary}

As indicated in the previous paragraphs, nonthermal systems do not appear to be able to separate all organic contaminants from the solid inorganic waste matrices to the level required by the UTSs. With adequate residence time, mixing, and sequencing of operations, the chemical oxidation and aqueous treatment processes are likely to achieve the required destruction of organic contaminants. The APC subsystems are designed, with redundancy, to remove particulates and toxic and radioactive contaminants that may carry over into the offgas from the primary treatment system. However, as with thermal systems, it is likely that trace amounts of toxic materials well below regulatory requirements will be in the gaseous and liquid effluent from these systems.

\subsection{Mercury Treatment}

In this section the methods for extracting mercury from solid matrices, for recovering and stabilizing mercury, and the potential for release are discussed and compared for thermal and nonthermal systems. Mercury is a particular problem because of its volatility and toxicity. This section addresses the TSWG principles "minimize effluents," and "minimize exposure now and in the future."

In both thermal and nonthermal systems, bulk mercury metal is removed from the waste in the frontend sorting process. Nonradioactive elemental mercury is recycled and radioactive elemental mercury is stabilized by amalgamation and disposed.

In all thermal systems, solid wastes identified as being contaminated with mercury are retorted to vaporize the mercury. The mercury is condensed, collected, and amalgamated for disposal. Trace levels of mercury may pass on to the APC system and be collected in sulfur-impregnated carbon filters. Solid waste that is not identified as mercury contaminated is treated in the primary thermal treatment unit where trace 
quantities of mercury that may be present are volatilized and pass to the APC system. As indicated in Section 3.4.4, mercury is removed from the offgas in the baghouse filter, scrubber unit, and sulfurimpregnated carbon filters. The quench and scrubber waters are treated in the aqueous waste treatment system.

In nonthermal systems, mercury is removed from solids by thermal desorption, washing, or solubilized in an acid solution (e.g., MEO, CWO, or acid digestion). In thermal desorption, mercury is volatilized from solids in the thermal desorber, condensed, and subsequently amalgamated for disposal. However, trace levels of vaporized mercury may pass on to the APC subsystem to be removed by sulfurimpregnated carbon filters, and trace levels may remain with the solids. To remove the trace quantities of mercury in the solids, a potassium iodide/iodine $\left(\mathrm{KI} / \mathrm{I}_{2}\right)$ leaching process that solubilizes approximately $98 \%$ of the remaining mercury and its compounds is used. The mercury removed is subsequently precipitated on steel wool as metallic mercury and then amalgamated for final disposal.

Washing removes soluble mercury compounds or entrains insoluble mercury in the wash water. Acid solutions solubilize most mercury compounds. The resulting wash water and spent acid solutions are treated in the aqueous waste treatment system where mercury is removed from wastewater by precipitation and filtration, evaporation, and ion exchange. The insoluble sludges are stabilized and immobilized in polymer. Thus, both thermal and nonthermal systems are designed to remove mercury and mercury compounds from the waste streams and immobilize the waste as an amalgam or in polymer for disposal. It is possible that trace levels of mercury in the offgas from the main thermal treatment unit or thermal desorber may enter the APC subsystem, or traces of mercury in the waste water from washing or chemical oxidation processes may enter the aqueous waste treatment subsystem. However, the APC and aqueous waste treatment systems are designed to remove mercury from these internal waste streams prior to discharge.

\subsection{Radionuclide Distribution}

This section addresses the TSWG principles "minimize effluents," and "minimize exposure now and in the future." The distribution of selected radionuclides throughout several thermal and nonthermal systems is evaluated to determine where the radionuclides are likely to accumulate, and the likely radiation levels in the final waste forms. Representative thermal and nonthermal systems were chosen for this distribution analysis. A total radionuclide input of $50 \mathrm{nCi}$ per gram of waste was assumed; thus, each waste stream is assumed to be contaminated with $50 \mathrm{nCi} / \mathrm{g}$ of radioactivity.

The selected radionuclides are shown in Table 3-9, which also shows the mass of each radionuclide that must be included to give a concentration of $50 \mathrm{nCi} / \mathrm{g}$. The INTS and ITTS studies used a total waste input of $2927 \mathrm{lbs} / \mathrm{hr}$ of waste, of which $1.77 \mathrm{~g} / \mathrm{hr}(1.3 \mathrm{ppm})$ consists of radionuclides. The input compounds were assumed to be tritium and the oxides of cesium, nickel, plutonium and uranium at 10 $\mathrm{nCi} / \mathrm{g}$ each. As these radionuclides enter the treatment processes with the various waste streams they may be volatilized, go into solution, or be converted to the oxide (tritiated water), chloride, or metal in accordance with equilibrium chemistry. For example, some of the highly insoluble nickel oxide is converted to soluble nickel chloride in the catalyzed wet oxidation process. Thus, the input and output compounds of these radionuclides represent a range of volatilities and solubilities. These input compounds and the compounds to which some are transformed are listed below:

- Tritium - highly volatile and reactive 
- Tritiated Water - very volatile and soluble, acts as ordinary water

- $\quad$ Cesium Oxide $\left(\mathrm{Cs}_{2} \mathrm{O}\right)$ - volatile and soluble

- Cesium Chloride $(\mathrm{CsCl})$ - volatile and soluble

- Nickel Oxide (NiO) - not volatile and insoluble

- Nickel Chloride $\left(\mathrm{NiCl}_{2}\right)$ - not volatile but soluble

- Plutonium Oxide $\left(\mathrm{PuO}_{2}\right)$ - not volatile and insoluble

- Uranium Oxide $\left(\mathrm{UO}_{2}\right)$ - not volatile and insoluble

In this analysis it was assumed that all radionuclides are evenly dispersed in the waste so that the separate input streams have radionuclide concentrations of $50 \mathrm{nCi} / \mathrm{g}$. Any tritium in the offgas is present as tritiated water $\left({ }^{3} \mathrm{H}_{2} \mathrm{O}\right)$. The tritiated water follows normal water through the systems and its fate may be different for the thermal and nonthermal systems. Water may be in the vapor form and vented up the stack with the other gases, it may be recycled internally after being processed through aqueous waste treatment, or it may be discharged to the environment after treatment. Insoluble compounds are treated as solids in a solid waste stream and subsequently stabilized; soluble compounds are fully dissolved in water and subsequently removed in the water treatment process. If compounds are reduced to the metallic form, they may remain in a metal melt or volatilize and go to the offgas for removal in the APC system.

It must be stressed that these assumptions are based on engineering judgment and that the fate of the radionuclides is not based on a detailed analysis of each unit operation. ASPEN Plus was used to calculate the conversion of the input compounds to oxides or chlorides using equilibrium chemistry. These compounds were then assumed to be distributed according to the assumptions stated above.

Table 3-9. Radionuclide input to thermal and nonthermal systems.

\begin{tabular}{|c|c|c|c|}
\hline Radionuclide & Half-Life (years) & Specific Activity (Ci/g) & $\begin{array}{l}\text { Mass of Radionuclide } \\
\text { Input (grams) }\end{array}$ \\
\hline${ }^{3} \mathbf{H}$ & 12.3 & 9730 & $1.37 \mathrm{E}-06$ \\
\hline${ }^{137} \mathrm{Cs}$ & 30.17 & 86.8 & $1.53 \mathrm{E}-04$ \\
\hline${ }^{59} \mathrm{Ni}$ & $8.00 \mathrm{E}+04$ & 0.0757 & $1.76 \mathrm{E}-01$ \\
\hline${ }^{239} \mathrm{Pu}$ & $2.41 E+04$ & 0.062 & $2.14 \mathrm{E}-01$ \\
\hline${ }^{233} \mathrm{U}$ & $1.59 \mathrm{E}+05$ & $9.65 \mathrm{E}-03$ & $1.38 \mathrm{E}+00$ \\
\hline Total Mass Input (g) & & & $1.77 \mathrm{E}+00$ \\
\hline
\end{tabular}


Table 3-10 shows the distribution of the radionuclides to the output streams in terms of specific activity (i.e., nanocuries per gram of waste). There is very little specific radioactivity in the offgas from either the thermal or nonthermal systems. This is due to the assumed removal of particulates from the offgas in the APC system and their subsequent stabilization in polymer, removal of volatile compounds in the quench or scrubber, and dilution by the gases generated by the destruction processes. In the nonthermal systems, the radionuclides tend to distribute among aqueous recycle, polymer, and mercury amalgam with somewhat less radioactivity in the grout. Salts and oxides of the radionuclides are assumed to be removed from the aqueous waste streams and stabilized in polymer. The higher concentrations of radionuclides in the aqueous phase is due to tritiated water. The radioactivity in the mercury amalgam is due to the assumed $50 \mathrm{nCi} / \mathrm{g}$ input diluted by copper for amalgamation. In System NT-2, the $3 \mathrm{lbs} / \mathrm{hr}$ of

Table 3-10. Radionuclide partitioning into output streams.

Radionuclide Concentration in Output Streams (nCi/g)

\begin{tabular}{|c|c|c|c|c|c|c|c|c|}
\hline Systems & Offgas $^{2}$ & $\begin{array}{l}\text { Aqueous } \\
\text { Recycle }\end{array}$ & Grout & $\begin{array}{l}\text { Polymer/ } \\
\text { Ceramic } \\
\end{array}$ & Slag & $\begin{array}{l}\text { Mercury } \\
\text { Amalgam }\end{array}$ & Metal & $\begin{array}{l}\text { Special } \\
\text { Waste } \\
\end{array}$ \\
\hline Rotary Kiln/Air (A-1) & 1 & 2.1 & 0 & 8.9 & 53.5 & 29.4 & 49.5 & 50 \\
\hline $\begin{array}{l}\text { Slagging Rotary Kiln } \\
\text { (A-7) }\end{array}$ & 0.7 & 0 & 0 & 8.9 & 50.9 & 29.4 & 0 & 50 \\
\hline $\begin{array}{l}\text { Rotary Kiln/Grout } \\
\text { (A-8) }\end{array}$ & 1 & 2.1 & 24.8 & 8.9 & 0 & 29.4 & 49.5 & 50 \\
\hline Plasma Furnace (C-1) & 3.4 & 0.2 & 0 & 8.9 & 44.5 & 29.4 & 125.8 & 50 \\
\hline Metal Melter (G-1) & 2.3 & 3.9 & 0 & 32.3 & 33.4 & 29.4 & 85.1 & 50 \\
\hline $\begin{array}{l}\text { Thermal Desorption } \\
\text { (NT-2) }\end{array}$ & 0 & 31 & 11.9 & 52.6 & N/A & 14.6 & 0 & 50 \\
\hline Wash (NT-3) & 1 & 13.1 & 10.1 & 49.7 & N/A & 29.4 & 0 & 50 \\
\hline $\begin{array}{l}\text { Catalyzed Wet Ox } \\
\text { (NT-5) }\end{array}$ & 0 & 18.7 & 18.9 & 50.8 & N/A & 28.9 & 0 & 50 \\
\hline
\end{tabular}

a. This is the output concentration from the APC. Various filters, scrubbers, etc. remove the radioactive particulates with an estimated decontamination factor of $10^{-10}$ to $10^{-12}$, which is below the detection limits for the offgas. The higher concentrations for some of the thermal systems are due to vaporized tritiated water. 
metallic mercury that contains the radionuclides is diluted by mercury vaporized in the thermal desorber and subsequently condensed. The radionuclides initially input to the desorber are distributed to the other solids and offgas stream and do not go with the condensed mercury.

In thermal systems, there is little specific radioactivity in the aqueous waste and the radionuclides tend to partition to the slag and the recyclable metals. The low concentration in the aqueous phase is due to the large quantities of water used by thermal systems in the quench and scrubber of the air pollution control systems. Radionuclides that are captured in the offgas filters or precipitated as salts in aqueous waste treatment are stabilized in polymer. The ash, where most of the oxides concentrate, is vitrified to produce a slag with a concentration near that of the input waste. The relatively high concentration in metals is due almost exclusively to ${ }^{59} \mathrm{Ni}$ when nickel chlorides and nickel oxides are reduced to the metal. For all systems, the radionuclides in the special waste pass through unaffected since no treatment was defined for this waste stream.

Although compounds of cesium, such as $\mathrm{CsCl}$, are very soluble and difficult to remove from waste waters, new technologies are being developed that will validate the assumption that radionuclides can be removed from the aqueous waste. These technologies include highly selective sequestering or chelating agents that form stable complexes with metal cations and that can concentrate or extract various radionuclides from wastewaters. Sequestering agents have been sorbed onto inert stationary supports such as resins or membranes. As the aqueous waste is passed through the membrane or packed resin column, the cations are extracted. Decontamination factors of $10^{5}$ and higher have been achieved using various sequestering agents on simulated nuclear waste streams. Similarly, as indicated in Section 3.4.4, use of several unit operations in series in the APC subsystem validates the assumption that radioactive particles are removed from the offgas before discharge.

\subsection{Resource Use}

In this section the use of resources by the various systems is compared. This includes electricity, natural gas, water, chemical reagents, and personnel. The percentage of reagents that is recovered and recycled to minimize consumption is discussed, and labor requirements and their effect on life-cycle cost are compared. This section addresses the TSWG principles concerning "minimizing effects on human health and the environment, including worker health and safety" by comparing the number of operational workers required for each system, as well as addressing the TSWG issue regarding material recycling and resource recovery.

\subsubsection{Energy Use}

The electricity and natural gas used is shown in Table 3-11. For all systems, the cost of electricity is assumed to be $\$ 0.05 / \mathrm{kWh}$, and the cost of natural gas is assumed to be $\$ 2.00 / \mathrm{MMBtu}$. The total cost of energy use over 20 years for thermal systems varies from approximately $0.1 \%$ to $1 \%$ of the total treatment cost - a significant use of energy in thermal systems is the electrical energy required to operate the vitrifiers, plasma torches, and metal melting processes. The total energy costs for nonthermal systems vary from 0.005 to $0.06 \%$ of the total treatment cost. Thus, energy use is not a major economic factor in evaluating treatment systems. However, in absolute terms nonthermal systems use less energy than most thermal systems.

As expected, the systems that use electrical energy have the highest energy cost. Nonthermal systems NT-1 and NT-3 use the mediated electrochemical oxidation process for organic destruction and have the highest energy cost. The thermal systems that use Joule heated vitrification 
Table 3-11. Comparison of energy use and cost.

\begin{tabular}{|c|c|c|c|c|c|}
\hline \multirow[b]{2}{*}{ System } & \multicolumn{3}{|c|}{ Energy Costs per Hour } & \multirow{2}{*}{$\begin{array}{c}\text { Energy Use } \\
\text { Relative to A-8 }\end{array}$} & \multirow{2}{*}{$\begin{array}{c}\text { Fraction of } \\
\text { Treatment Cost }\end{array}$} \\
\hline & Electrical Energy $^{\mathrm{a}}$ & Natural Gas ${ }^{b}$ & Total Energy Cost & & \\
\hline Rotary Kiln/Air (A-1) & $\$ 29.36$ & $\$ 17.97$ & $\$ 47.33$ & 2.36 & 0.00176 \\
\hline Rotary Kiln/Oxygen (A-2) & $\$ 29.36$ & $\$ 5.89$ & $\$ 35.25$ & 1.76 & 0.00131 \\
\hline Slagging Rotary Kiln (A-7) & $\$ 0.00$ & $\$ 33.36$ & $\$ 33.36$ & 1.67 & 0.00139 \\
\hline Rotary Kiln/Grout (A-8) & $\$ 2.06$ & $\$ 17.97$ & $\$ 20.03$ & 1.00 & 0.00072 \\
\hline Plasma Furnace (C-1) & $\$ 163.54$ & $\$ 0.00$ & $\$ 163.54$ & 8.16 & 0.00666 \\
\hline Metal Melter (G-1) & $\$ 215.08$ & $\$ 0.00$ & $\$ 215.08$ & 10.74 & 0.00916 \\
\hline Steam Reforming (H-1) & $\$ 42.59$ & $\$ 7.83$ & $\$ 50.42$ & 2.52 & 0.00185 \\
\hline Grout Debris (NT-1) & $\$ 67.98$ & $\$ 1.25$ & $\$ 69.23$ & 3.46 & 0.00194 \\
\hline Thermal Desorption (NT-2) & $\$ 0.38$ & $\$ 2.41$ & $\$ 2.79$ & 0.14 & 0.00008 \\
\hline Wash (NT-3) & $\$ 93.52$ & $\$ 0.37$ & $\$ 93.89$ & 4.69 & 0.00253 \\
\hline Acid Digestion (NT-4) & $\$ 0.61$ & $\$ 1.48$ & $\$ 2.09$ & 0.10 & 0.00005 \\
\hline Catalyzed Wet Ox NT-5) & $\$ 0.59$ & $\$ 1.30$ & $\$ 1.89$ & 0.09 & 0.00005 \\
\hline \multicolumn{6}{|c|}{ a. Electricity cost based on $\$ 0.05 / \mathrm{kWh}$} \\
\hline
\end{tabular}


(Systems A-1, A-2, and H-1) have higher energy costs than those that use nonthermal stabilization (i.e., System A-8 uses grout). System A-7 has high energy costs due to the large amount of natural gas required to reach slagging temperatures. Systems that use electrical energy in the entire treatment process (i.e., Systems C-1 and G-1) have the highest energy costs.

The nonthermal systems that use electrical energy in the MEO process have energy costs ranging from $\$ 13$ to $\$ 22$ per hour. The other nonthermal systems have significantly lower energy costs, ranging from $\$ 2$ to $\$ 3$ per hour. Thermal systems that use natural gas and produce waste forms in Joule-heated melters have energy costs ranging from $\$ 33$ to $\$ 50$ per hour, whereas systems that use electrical energy to treat all the waste have the highest energy costs at $\$ 164$ to $\$ 215$ per hour.

\subsubsection{Water Use}

System water requirements, recycling, discharge, and consumption are shown in Table 3-12. Water is recycled in all systems, and most systems generate more water than is required so that some water is discharged after treatment. (This water is generated as a product of oxidation of organic material to carbon dioxide and water.) The typical discharge rate for thermal and nonthermal systems is between 0.1 and 1.5 gallons per minute (gpm). In general, the water requirements for thermal systems are significantly greater than for nonthermal systems, primarily due to the larger offgas system requirements and the use of water for quenching (cooling) and offgas scrubbing. However, only two thermal systems consume water: System A-8 consumes $0.07 \mathrm{gpm}$ due to the water requirement for grout, and System H-1 consumes about $1 \mathrm{gpm}$ due to the need for steam in the steam reforming or gasification process. Water discharge and consumption is small ( $<2 \mathrm{gpm})$ for all systems.

The thermal systems that require the most water are those that use air for combustion and have the largest amount of offgas. In these systems, water is used in quenching to cool the large volume of offgas, and in scrubbing to remove particulates and acid gases. System A-8 requires more water than System A-1 due to the need for water for the grouting process, and System A-1 generates slightly more water due to oxidation of organics in the vitrifier. In System $\mathrm{H}-1$, syngas is produced in the gasifier, cleaned in the APC subsystem, and oxidized to $\mathrm{CO}_{2}$ and water in the thermal oxidizer. In this case, the water exits System H-1 as a vapor and is not available for recycle.

Of the nonthermal systems, System NT-1 has less water discharge because the debris is grouted without treatment, so the hydrogen in the debris stream is not converted (oxidized) to water. In Systems NT-2 and NT-3, the debris is treated and the hydrogen associated with the contaminates on the debris is converted to water and is available for recycle or discharge. In Systems NT-4 and NT-5, all the hydrogen associated with debris, including the hydrogen associated with the soft debris matrix, is converted to water that is available for recycle or discharge. The discharge from System NT-5 is less than that from NT-4 because water is required to produce grout in System NT-5.

\subsubsection{Chemical Use}

Chemicals are used in nonthermal systems to oxidize organic contaminants, and in both thermal and nonthermal systems to remove contaminants from gaseous or aqueous waste streams or to neutralize acids. The chemicals and quantities used in these systems are shown in Table 3-13. These quantities are for pure compounds as determined by the mass balance calculations. In practice, several of these compounds are diluted with water to form mixtures for safe transport and storage. 
Table 3-12. Water requirements, recycling, discharge and consumption (lbs/hr).

\begin{tabular}{lcccc}
\hline \multicolumn{1}{c}{ System } & Water Required & $\begin{array}{c}\text { Water Available } \\
\text { for Recycle }\end{array}$ & Water Discharges & Water Consumption \\
\hline Rotary Kiln/Air (A-1) & 13549 & 13948 & 399 & 0 \\
Rotary Kiln/Oxygen (A-2) & 9455 & 10343 & 888 & 0 \\
Slagging Rotary Kiln (A-7) & 18424 & 19202 & 778 & 0 \\
Rotary Kiln/Grout (A-8) & 13828 & 13790 & -38 & 38 \\
Plasma Furnace (C-1) & 6183 & 6646 & 463 & 0 \\
Metal Melter (G-1) & 555 & 642 & 87 & 0 \\
Steam Reforming (H-1) & 3731 & 3244 & -487 & 487 \\
Grout Debris (NT-1) & 1041 & 1101 & 59 & 0 \\
Thermal Desorption (NT-2) & 1051 & 1186 & 135 & 0 \\
Wash (NT-3) & 1248 & 1424 & 176 & 0 \\
Acid Digestion (NT-4) & 1010 & 1790 & 780 & 0 \\
Catalyzed Wet Ox (NT-5) & 1231 & 1795 & 564 & 0
\end{tabular}

Note: The majority of the water used in thermal systems is for quenching the offgas to lower the temperature and volume, or for scrubbing acid gases from the offgas.

Table 3-13. Comparison of chemical reagent use (lbs/hr).

\begin{tabular}{|c|c|c|c|c|c|c|}
\hline $\begin{array}{l}\text { Reagents } \\
\text { (lbs/hr) }^{\mathrm{a}}\end{array}$ & $\begin{array}{c}\text { All } \\
\text { Thermal } \\
\text { Systems }^{b}\end{array}$ & $\begin{array}{l}\text { Grout } \\
\text { Debris } \\
\text { (NT-1) } \\
\end{array}$ & $\begin{array}{l}\text { Thermal } \\
\text { Desorption } \\
\text { (NT-2) }\end{array}$ & $\begin{array}{l}\text { Wash } \\
\text { (NT-3) }\end{array}$ & $\begin{array}{l}\text { Acid Digestion } \\
\text { (NT-4) }\end{array}$ & $\begin{array}{c}\text { Catalyzed Wet } \\
\text { Oxidation } \\
\text { (NT-5) } \\
\end{array}$ \\
\hline Copper (Cu) & 5 & 1.9 & 3.6 & 1.8 & 1.8 & 1.9 \\
\hline $\begin{array}{l}\text { Sodium Hydroxide } \\
\text { (NaOH) }\end{array}$ & 78 & 58 & 84.7 & 58.5 & 104 & 93.4 \\
\hline CWO Acid Solution & 0 & 0 & 9.7 & 0 & 0 & 24.5 \\
\hline $\begin{array}{l}\text { Ferric Chloride } \\
\left(\mathrm{FeCl}_{3}\right)\end{array}$ & & & 5.82 & & & 14.7 \\
\hline Hydrochloric & & & 1.1 & & & 2.8 \\
\hline Acid $(\mathrm{HCl})$ & & & & & & \\
\hline Water & & & 2.8 & & & 7.0 \\
\hline Ammonia $\left(\mathrm{NH}_{3}\right)$ & 0 & 4 & 0 & 5.5 & 6.8 & $\mathbf{0}$ \\
\hline Nitric Acid $\left(\mathrm{HNO}_{3}\right)$ & 0 & 21.4 & 0 & 28.8 & 73.7 & 0 \\
\hline $\begin{array}{l}\text { Silver Nitrate } \\
\left(\mathrm{AgNO}_{3}\right)\end{array}$ & 0 & 2.9 & 0 & 4.7 & $\mathbf{0}$ & 0 \\
\hline $\begin{array}{l}\text { Hydrogen Peroxide } \\
\left(\mathrm{H}_{2} \mathrm{O}_{2}\right)\end{array}$ & 0 & 29.2 & 0.6 & 48.6 & 0.6 & 0.6 \\
\hline \multicolumn{7}{|c|}{$\begin{array}{l}\text { a. These quantities are for pure compounds as determined by the mass balance calculations. In practice, some of these } \\
\text { compounds are not sold in the pure state and will be diluted with water for transportation or storage. }\end{array}$} \\
\hline $\begin{array}{l}\text { b. The molten metal sys } \\
\text { agent. }\end{array}$ & -1) uses & ar of & ydroxide a & 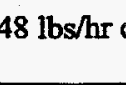 & lcium oxide (C & as a fluxing \\
\hline
\end{tabular}


Reagent consumption is the largest for sodium hydroxide ( $\mathrm{NaOH})$, which is used in thermal and nonthermal systems to neutralize the acid gas scrubber solution (primarily hydrochloric and sulfuric acids) and in nonthermal systems to neutralize spent acids from the chemical oxidation processes. Systems NT-1 and NT-3 also use $\mathrm{NaOH}$ to regenerate silver from silver chloride. All systems use approximately the same amount of $\mathrm{NaOH}$; nonthermal systems use 50 to $100 \mathrm{lbs} / \mathrm{hr}$, and thermal systems use $78 \mathrm{lbs} / \mathrm{hr}$ with the exception of System G-1 (metal melter) which uses $16 \mathrm{lbs} / \mathrm{hr}$. The lower use of NaOH for System G-1 is due to the properties of the slag additives which allow some acid gas scrubbing within the reactor and therefore reduce the size of the APC system. Although the metal melter system uses less $\mathrm{NaOH}$, approximately $48 \mathrm{lbs} / \mathrm{hr}$ of fluxes and catalysts such as calcium oxide $(\mathrm{CaO})$ are added to the system to assist in partitioning radionuclides into the slag phase.

Little hydrogen peroxide is used in the UV photooxidation process in thermal and nonthermal systems because most of the organics are separated from the aqueous waste and sent to the acid-based organic destruction process. Systems NT-1 and NT-3 use a significant amount of hydrogen peroxide in the silver nitrate recovery process. Nonthermal systems use acids for organic destruction. Systems NT-1 and NT-3 use 21 and $29 \mathrm{lbs} / \mathrm{hr}$ of nitric acid ( $\mathrm{HNO}_{3}$ ), respectively, in the MEO process and System NT-4 uses $74 \mathrm{lbs} / \mathrm{hr}$ of nitric acid to oxidize organic liquids and sludges and soft debris. Systems NT-2 and NT-5 use approximately 1 to $3 \mathrm{lbs} / \mathrm{hr}$ of concentrated $\mathrm{HCl}$ mixed with water and 6 to $15 \mathrm{lbs} / \mathrm{hr}$ of nonhazardous $\left(\mathrm{FeCl}_{3}\right)$ powder to produce the catalytic wet oxidation solution. A small amount of ammonia (4 to $7 \mathrm{lbs} / \mathrm{hr}$ ) is used in Systems NT-1, NT-3, and NT-4 to convert nitrogen oxides in the offgas to nitrogen. Small amounts of silver nitrate are used in Systems NT-1 and NT-3 to replace the silver nitrate lost in the MEO process.

Most of the chemicals are recovered and recycled. Approximately $99 \%$ of the nitric acid and silver nitrate may be recoverable from the MEO process, and $99 \%$ of the nitric acid from the acid digestion process. The hydrochloric acid that escapes from the CWO reactor is condensed and recovered. The acid solutions that are not recovered are treated in the aqueous waste treatment system and neutralized to precipitate the salts, which are stabilized for disposal. This eliminates discharge of hazardous materials generated in the treatment process.

Nonthermal systems consume approximately $40 \%$ more chemicals than thermal systems. However, this larger quantity has a minimal effect on truck traffic to the facility.

\subsubsection{Personnel}

The personnel required for thermal and nonthermal systems in terms of full-time equivalent (FTE) workers is shown in Table 3-14. A full-time equivalent worker is one person working a 40 hour week for a 52-week year. The major differences between the number of workers required for thermal and nonthermal system operations are in receiving and preparation and in certification and shipping. Significantly more sorting, characterizing, and waste preparation is required for nonthermal systems. Certification and shipping requires 3 times as many people in the nonthermal systems due to the larger (a factor of 3 ) volume of stabilized waste shipped to disposal. The exception is System A-8, which uses grout for stabilization and has a volume of waste shipped to disposal similar to that of the nonthermal systems.

Other areas of significant difference include:

- More personnel are required to operate the nonthermal primary and secondary stabilization processes than to operate a vitrifier and the small polymer stabilization process in the thermal systems 
Table 3-14a. Typical thermal treatment system operational personnel requirements (FTEs).

\begin{tabular}{|c|c|c|c|c|c|c|c|}
\hline Subsystem & $\begin{array}{c}\text { Rotary } \\
\text { Kiln/Air } \\
(\mathrm{A}-1)\end{array}$ & $\begin{array}{c}\text { Rotary } \\
\text { Kiln/Oxygen } \\
\text { (A-2) }\end{array}$ & $\begin{array}{c}\text { Slagging } \\
\text { Rotary } \\
\text { Kiln } \\
\text { (A-7) } \\
\end{array}$ & $\begin{array}{c}\text { Rotary } \\
\text { Kiln/Grout } \\
(\mathrm{A}-8) \\
\end{array}$ & $\begin{array}{c}\text { Plasma } \\
\text { Furnace } \\
(\mathrm{C}-1)\end{array}$ & $\begin{array}{c}\text { Metal } \\
\text { Melter } \\
\text { (G-1) }\end{array}$ & $\begin{array}{c}\text { Steam } \\
\text { Reforming } \\
(\mathrm{H}-1)\end{array}$ \\
\hline $\begin{array}{l}\text { Administration } \\
\text { Building }\end{array}$ & 27 & 27 & 27 & 27 & 27 & 27 & 27 \\
\hline $\begin{array}{l}\text { Receiving and } \\
\text { Preparation }\end{array}$ & 112 & 112 & 112 & 112 & 112 & 112 & 132 \\
\hline Organic Destruction & 16 & 16 & 20 & 16 & 16 & 20 & 20 \\
\hline Air Pollution Control & 4 & 4 & 4 & 4 & 4 & 4 & 4 \\
\hline Primary Stabilization & 16 & 16 & & 8 & 16 & 16 & 16 \\
\hline $\begin{array}{l}\text { Secondary } \\
\text { Stabilization }\end{array}$ & 8 & 8 & 8 & 8 & 8 & 8 & 8 \\
\hline Metal Melting & 5 & 5 & & 5 & & & 5 \\
\hline $\begin{array}{l}\text { Metal } \\
\text { Decontamination }\end{array}$ & 5 & 5 & 5 & 5 & 5 & & 5 \\
\hline Lead Recovery & 8 & 8 & 8 & 8 & 8 & 8 & 8 \\
\hline $\begin{array}{l}\text { Mercury } \\
\text { Amalgamation }\end{array}$ & 4 & 4 & 4 & 4 & 4 & 4 & 4 \\
\hline \multicolumn{8}{|l|}{ Process Residue/Soil } \\
\hline \multicolumn{8}{|l|}{ Debris Treatment } \\
\hline $\begin{array}{l}\text { Aqueous Waste } \\
\text { Treatment }\end{array}$ & 16 & 16 & 16 & 16 & 16 & 16 & 16 \\
\hline $\begin{array}{l}\text { Special Waste } \\
\text { Treatment }\end{array}$ & 2 & 2 & 2 & 2 & 2 & 2 & 2 \\
\hline $\begin{array}{l}\text { Certification and } \\
\text { Shipping }\end{array}$ & 32 & 32 & 40 & 91 & 32 & 32 & 32 \\
\hline Support Systems & 5 & 5 & 5 & 5 & 5 & 5 & 5 \\
\hline Total & 260 & 260 & 251 & 311 & 255 & 254 & 284 \\
\hline
\end{tabular}

System A-7 has 8 more FTEs for Certification and Shipping than is shown in Reference 2. This is based on a revised estimate of the FTEs required in this area due to the variations in the volume of waste destined for disposal (i.e., more personnel are required to move and handle larger final waste form volumes). This increase is reflected in the cost estimates. 
Table 3-14b. Typical nonthermal treatment system operational personnel requirements (FTEs).

\begin{tabular}{|c|c|c|c|c|c|}
\hline Subsystem & $\begin{array}{c}\text { Grout Debris } \\
\text { (NT-1) }\end{array}$ & $\begin{array}{c}\text { Thermal } \\
\text { Desorption } \\
\text { (NT-2) }\end{array}$ & $\begin{array}{l}\text { Wash } \\
\text { (NT-3) }\end{array}$ & $\begin{array}{c}\text { Acid } \\
\text { Digestion } \\
(\mathrm{NT}-4) \\
\end{array}$ & $\begin{array}{l}\text { Catalyzed Wet } \\
\text { Oxidation } \\
\text { (NT-5) }\end{array}$ \\
\hline $\begin{array}{l}\text { Administration } \\
\text { Building }\end{array}$ & 32 & 32 & 32 & 32 & 32 \\
\hline $\begin{array}{l}\text { Receiving and } \\
\text { Preparation }\end{array}$ & 170 & 170 & 170 & 170 & 170 \\
\hline Organic Destruction & 12 & 12 & 12 & 30 & 26 \\
\hline Air Pollution Control & 4 & 4 & 4 & 4 & 4 \\
\hline Primary Stabilization & 8 & 8 & 8 & 45 & 8 \\
\hline $\begin{array}{l}\text { Secondary } \\
\text { Stabilization }\end{array}$ & 38 & 38 & 40 & 5 & 38 \\
\hline \multicolumn{6}{|l|}{ Metal Melting } \\
\hline $\begin{array}{l}\text { Metal } \\
\text { Decontamination }\end{array}$ & 4 & 4 & 4 & 4 & 4 \\
\hline Lead Recovery & 3 & 3 & 3 & 3 & 3 \\
\hline $\begin{array}{l}\text { Mercury } \\
\text { Amalgamation }\end{array}$ & 1 & 1 & 1 & 1 & 1 \\
\hline Process Residue/Soil & 10 & 16 & 3 & 10 & 10 \\
\hline Debris Treatment & & & 16 & 8 & 8 \\
\hline $\begin{array}{l}\text { Aqueous Waste } \\
\text { Treatment }\end{array}$ & 5 & 5 & 5 & 5 & 5 \\
\hline $\begin{array}{l}\text { Special Waste } \\
\text { Treatment }\end{array}$ & 3 & 3 & 3 & 3 & 3 \\
\hline $\begin{array}{l}\text { Certification and } \\
\text { Shipping }\end{array}$ & 106 & 105 & 110 & 87 & 88 \\
\hline Support Systems & 5 & 5 & 5 & 5 & 5 \\
\hline Total & 401 & 406 & 416 & 412 & 405 \\
\hline
\end{tabular}


- More personnel are required for separation and organic destruction processes in nonthermal Systems NT-4 and NT-5 than are required for organic destruction in thermal systems

- More personnel are required in the thermal systems to operate the aqueous waste treatment subsystem because of the larger volume of aqueous waste, and more personnel are required to operate the retort in the thermal systems' mercury amalgamation process.

System A-7 has slightly more personnel in certification and shipping than the other thermal systems (except A-8) because of the slightly higher volume of waste sent to disposal (see Table 3-6b). This higher volume is due to the metal that is incorporated into the melt from the slagging kiln and subsequently sent to disposal. It should be noted that the number of personnel in the certification and shipping subsystems reported in the INTS study ${ }^{4}$ and in this report are a function of the final waste form volume and are based on a recent time and motion study. ${ }^{6}$ Therefore, the FTEs reported here for System A-7 are slightly greater than those reported in Reference 2.

In summary, nonthermal systems require approximately $50 \%$ more people than thermal systems, primarily due to increased requirements in the receiving and preparation, certification and shipping, and waste stabilization areas.

If the final waste form volume from nonthermal systems can be reduced to the level of that from thermal systems, then the labor in the nonthermal certification and shipping subsystem could be reduced by approximately $65 \%$. This could be achieved by replacing the grout and most of the polymer operations with vitrification. At the rate of $\$ 140,000 / \mathrm{FTE} /$ year, this would produce a cost savings of approximately $\$ 400$ million in operating and maintenance (O\&M) costs over 20 years. Similarly, if receiving and preparation can be simplified by a 50\% reduction in sorting and characterization, then $\$ 160$ million in O\&M costs could be saved for thermal systems, and $\$ 240$ million could be saved for nonthermal systems.

\subsection{Transportation}

This section addresses the TSWG concern regarding transportation impacts of a centralized facility by comparing the estimated traffic for a single, centralized treatment facility for the various treatment systems. Waste, reagents, and other supplies are transported to the treatment facility, and stabilized waste and recyclable metals are transported from the facility. It is assumed that final waste forms and metals are transported off-site using the same trucks that delivered waste and chemicals to the facility. The number of truck loads per year entering and leaving the facility is shown in Table 3-15 and Figure 3-12.

The chemical reagents required to treat the waste were identified in Table 3-13 as pure compounds; however, many chemicals are supplied commercially as solutions. Thus, sodium hydroxide is assumed to be delivered as a $50 \%$ mixture of $\mathrm{NaOH}$ and water, hydrogen peroxide as a $70 \%$ mixture, and hydrochloric acid as the commercial grade $31 \%$ mixture. The other reagents are powdered solids or are sufficiently concentrated to be assumed to be delivered as the pure compound in calculating weight and volume for transportation. In addition to these chemicals, grout material, polyethylene for polymer stabilization or magnesium oxide for the production of phosphate-bonded ceramics, and soil or glass-forming additives for vitrifying the waste in thermal systems are transported to the facility.

Assuming solids are transported in trucks capable of carrying 44,000 pounds, and liquids are transported in 3500 gallon tankers, the material requirements were translated into the number of truck loads per year required to transport the material into the facility. This is shown in Table 3-15. The 
Table 3-15. Comparison of truck traffic associated with the treatment facilities (loaded trucks per year).

\begin{tabular}{|c|c|c|c|c|c|c|c|}
\hline \multirow[b]{2}{*}{ System } & \multicolumn{4}{|c|}{ Incoming Truck Loads ${ }^{\mathrm{a}}$} & \multicolumn{3}{|c|}{ Outgoing Truck Loads } \\
\hline & Waste & Reagent $^{\text {b }}$ & $\begin{array}{c}\text { Stabilizing } \\
\text { Agent }\end{array}$ & Total & $\begin{array}{l}\text { Waste to } \\
\text { Disposal }\end{array}$ & $\begin{array}{l}\text { Metals/ } \\
\text { Lead to } \\
\text { Storage }\end{array}$ & Total \\
\hline Rotary Kiln/Air (A-1) & 269 & 14 & 58 & 341 & 177 & 57 & 234 \\
\hline $\begin{array}{l}\text { Rotary Kiln/Oxygen } \\
\text { (A-2) }\end{array}$ & 269 & 14 & 58 & 341 & 177 & 57 & 234 \\
\hline $\begin{array}{l}\text { Slagging Rotary Kiln } \\
\text { (A-7) }\end{array}$ & 269 & 14 & 63 & 346 & 193 & 45 & 237 \\
\hline Rotary Kiln/Grout & 269 & 14 & 210 & 493 & 336 & 57 & 393 \\
\hline (A-8) & & & & & & & \\
\hline Plasma Furnace (C-1) & 269 & 14 & 56 & 339 & 171 & 60 & 231 \\
\hline Metal Melter (G-1) & 269 & 8 & 51 & 327 & 164 & 58 & 223 \\
\hline Steam Reforming (H-1) & 269 & 14 & 58 & 341 & 177 & 57 & 234 \\
\hline Grout Debris (NT-1) & 269 & 17 & 198 & 484 & 428 & 41 & 470 \\
\hline $\begin{array}{l}\text { Thermal Desorption } \\
\text { (NT-2) }\end{array}$ & 269 & 16 & 196 & 480 & 423 & 41 & 464 \\
\hline Wash (NT-3) & 269 & 21 & 189 & 479 & 409 & 41 & 451 \\
\hline Acid Digestion (NT-4) & 269 & 27 & 158 & 454 & 336 & 41 & 377 \\
\hline $\begin{array}{l}\text { Catalyzed Wet 0x } \\
\text { (NT-5) }\end{array}$ & 269 & 18 & 162 & 449 & 350 & 41 & 391 \\
\hline \multicolumn{8}{|c|}{$\begin{array}{l}\text { a. Solids are assumed to be carried in } 44,000 \mathrm{lb} \text { trucks, and liquids in } 3,500 \text { gallon tankers. Some incoming trucks may leave loaded with stabilized } \\
\text { waste or metals if storage and disposal are off-site. }\end{array}$} \\
\hline
\end{tabular}




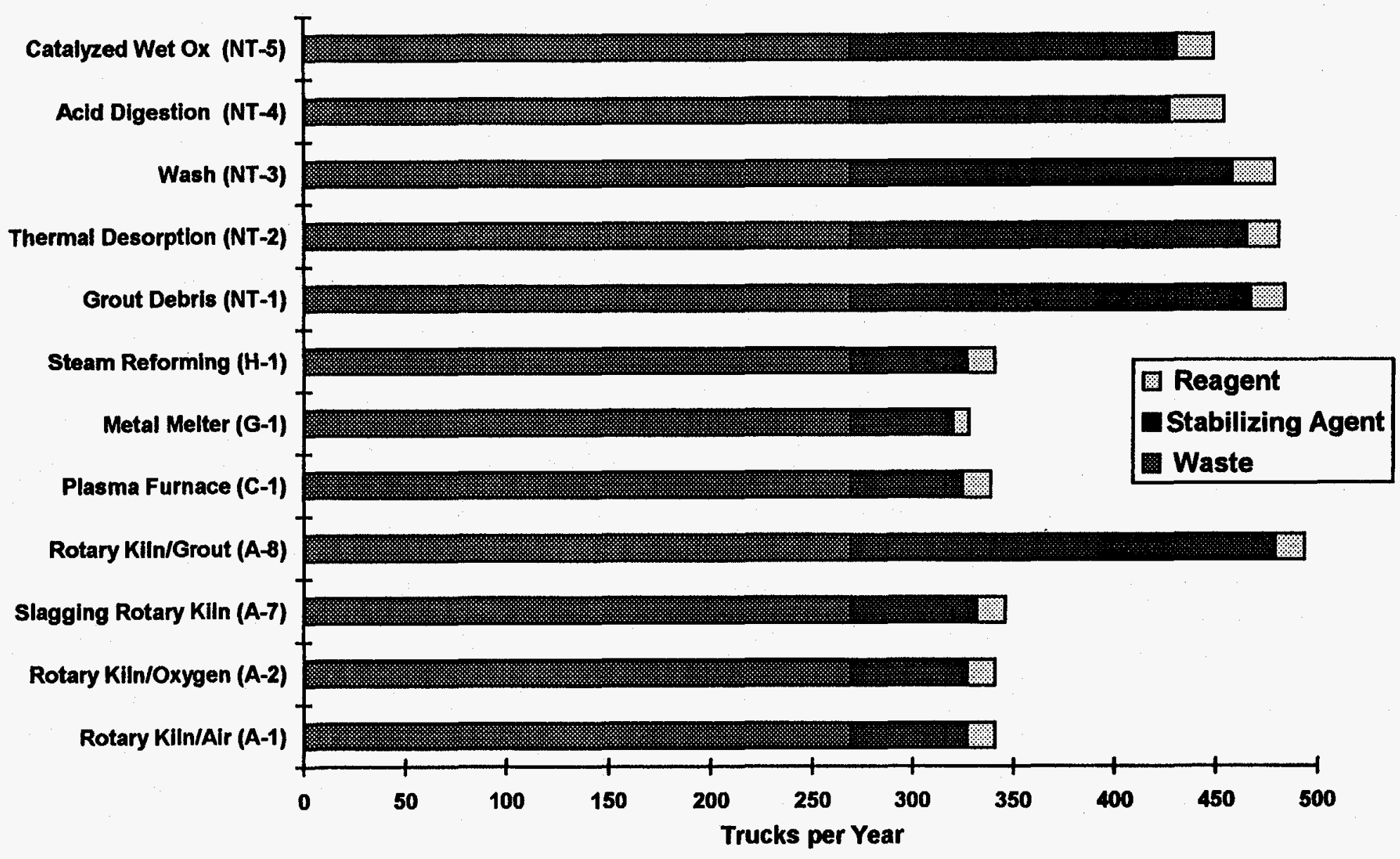

Figure 3-12. Incoming truck traffic (trucks per year). 
transport of potentially hazardous chemical reagents into the facility requires approximately 20 truck loads per year for nonthermal systems, and varies from 8 to 14 truck loads per year for thermal systems. Most of this material is sodium hydroxide.

For all the systems, the majority of incoming truck traffic is waste (269 loads per year). For nonthermal systems, the next largest quantity transported to the facility is nonhazardous stabilizing agents (156 and 199 loads per year for Systems NT-4 and NT-1, respectively). Thermal System A-8, in which grout is used for stabilization, requires 210 truck loads per year of grout material; the other thermal systems require 50 to 60 loads per year of stabilizing agents, which are $90 \%$ soil for vitrification and $10 \%$ polyethylene.

Total incoming truck traffic for nonthermal treatment facilities ranges from 450 to 500 loads per year. Truck traffic for thermal systems is approximately 350 loads per year, except for System A-8 which requires 500 loads per year.

For the ITTS and INTS studies, it was assumed that the waste disposal site and the recovered metal storage facility would be located on the same site as the treatment facility. For this scenario, the trucks delivering supplies and waste to the facility will leave the site empty. However, if storage and disposal are off-site, then most of the trucks leaving the site could be loaded with stabilized waste and metals. Tanker trucks would leave empty since there are no liquid wastes sent to disposal. Nonthermal systems require approximately 100 more truck loads per year than thermal systems. This translates to approximately 2 additional trucks per week entering and leaving the nonthermal treatment facility.

In addition to truck traffic transporting waste and materials to and from the facility, workforce transportation will also impact the local community. As indicated in Table 3-14, nonthermal systems required a larger workforce and, therefore, more traffic.

It must be emphasized that this analysis was for a single, centralized facility. With this assumption, transportation costs do not discriminate between systems; however, an evaluation of transportation costs is contained in Reference 4, and work is ongoing to evaluate transportation risk and the cost of transportation if more than one treatment facility is assumed.

\subsection{Comparison of Subsystem Costs and Material Balances}

In this section the differences in the major subsystems and their effect on performance, cost, and uncertainty are identified and compared. In particular, the mass flows to the subsystem are identified, and the amount of solids and other residue recycled, sent to other subsystems, emitted, or sent to disposal are identified and compared. Subsystem costs, and the percentages of total cost allocated to each subsystem, are shown in Table 3-16. Table 3-17 provides a breakout of the capital costs required by each subsystem and the percentage of capital costs allocated to each subsystem. Capital costs include design, facility construction, equipment, management, and contingency costs. The specific subsystems considered here include receiving and preparation, main treatment process (which includes separation processes for nonthermal systems), air pollution control, aqueous waste treatment, metal and lead treatment and/or decontamination, and stabilization. 
Table 3-16a. Thermal subsystem costs (\$ millions) and percentages of total costs.

\begin{tabular}{|c|c|c|c|c|c|c|c|c|c|c|c|c|c|c|}
\hline \multirow[b]{2}{*}{ Subsystem } & \multicolumn{2}{|c|}{$\begin{array}{c}\text { Rotary Kiln/Air } \\
\text { (A-1) }\end{array}$} & \multicolumn{2}{|c|}{$\begin{array}{c}\text { Rotary } \\
\text { Kiln/Oxygen } \\
\text { (A-2) } \\
\end{array}$} & \multicolumn{2}{|c|}{$\begin{array}{c}\text { Slagging } \\
\text { Rotary Kiln } \\
\text { (A-7) } \\
\end{array}$} & \multicolumn{2}{|c|}{$\begin{array}{c}\text { Rotary } \\
\text { Kiln/Grout } \\
\text { (A-8) }\end{array}$} & \multicolumn{2}{|c|}{$\begin{array}{l}\text { Plasma Furnace } \\
\text { (C-1) }\end{array}$} & \multicolumn{2}{|c|}{$\begin{array}{c}\text { Metal Melter } \\
\text { (G-1) }\end{array}$} & \multicolumn{2}{|c|}{$\begin{array}{c}\text { Steam } \\
\text { Reforming } \\
(\mathbf{H}-1) \\
\end{array}$} \\
\hline & Cost & Percent & Cost & Percent & Cost & Percent & Cost & Percent & Cost & Percent & Cost & Percent & Cost & Percent \\
\hline Front-End Handling & $\$ 667$ & $27 \%$ & $\$ 667$ & $27 \%$ & $\$ 660$ & $30 \%$ & $\$ 667$ & $23 \%$ & $\$ 660$ & $29 \%$ & $\$ 637$ & $30 \%$ & $\$ 783$ & $32 \%$ \\
\hline Organic Destruction & $\$ 162$ & $7 \%$ & $\$ 199$ & $8 \%$ & $\$ 246$ & $11 \%$ & $\$ 162$ & $6 \%$ & $\$ 352$ & $16 \%$ & $\$ 364$ & $17 \%$ & $\$ 185$ & $8 \%$ \\
\hline Thermal Desorption & $\$ 0$ & $0 \%$ & $\$ 0$ & $0 \%$ & $\$ 0$ & $0 \%$ & $\$ 0$ & $0 \%$ & $\$ 0$ & $0 \%$ & $\$ 0$ & $0 \%$ & $\$ 0$ & $0 \%$ \\
\hline Wash & $\$ 0$ & $0 \%$ & $\$ 0$ & $0 \%$ & $\$ 0$ & $0 \%$ & $\$ 0$ & $0 \%$ & $\$ 0$ & $0 \%$ & $\$ 0$ & $0 \%$ & $\$ 0$ & $0 \%$ \\
\hline Total Primary Treatment & $\$ 162$ & $7 \%$ & $\$ 199$ & $8 \%$ & $\$ 246$ & $11 \%$ & $\$ 162$ & $6 \%$ & $\$ 352$ & $16 \%$ & $\$ 364$ & $17 \%$ & $\$ 185$ & $8 \%$ \\
\hline Aqueous Waste & $\$ 149$ & $6 \%$ & $\$ 149$ & $6 \%$ & $\$ 148$ & $7 \%$ & $\$ 149$ & $5 \%$ & $\$ 149$ & $7 \%$ & $\$ 120$ & $6 \%$ & $\$ 54$ & $2 \%$ \\
\hline Air Pollution Control & $\$ 115$ & $5 \%$ & $\$ 76$ & $3 \%$ & $\$ 114$ & $5 \%$ & $\$ 115$ & $4 \%$ & $\$ 80$ & $4 \%$ & $\$ 85$ & $4 \%$ & $\$ 88$ & $4 \%$ \\
\hline Stabilization & $\$ 377$ & $15 \%$ & $\$ 376$ & $15 \%$ & $\$ 132$ & $6 \%$ & $\$ 221$ & $8 \%$ & $\$ 133$ & $6 \%$ & $\$ 133$ & $6 \%$ & $\$ 377$ & $15 \%$ \\
\hline Metal Recovery & $\$ 235$ & $10 \%$ & $\$ 235$ & $10 \%$ & $\$ 143$ & $6 \%$ & $\$ 235$ & $8 \%$ & $\$ 143$ & $6 \%$ & $\$ 81$ & $4 \%$ & $\$ 235$ & $10 \%$ \\
\hline Special Waste & $\$ 29$ & $1 \%$ & $\$ 29$ & $1 \%$ & $\$ 29$ & $1 \%$ & $\$ 29$ & $1 \%$ & $\$ 29$ & $1 \%$ & $\$ 30$ & $1 \%$ & $\$ 29$ & $1 \%$ \\
\hline Certification \& Shipping & $\$ 193$ & $8 \%$ & $\$ 193$ & $8 \%$ & $\$ 216$ & $10 \%$ & $\$ 411$ & $14 \%$ & $\$ 193$ & $9 \%$ & $\$ 193$ & $9 \%$ & $\$ 193$ & $8 \%$ \\
\hline Administration \& Support & $\$ 240$ & $10 \%$ & $\$ 240$ & $10 \%$ & $\$ 249$ & $11 \%$ & $\$ 240$ & $8 \%$ & $\$ 240$ & $11 \%$ & $\$ 249$ & $12 \%$ & $\$ 249$ & $10 \%$ \\
\hline Disposal & $\$ 266$ & $11 \%$ & $\$ 266$ & $11 \%$ & $\$ 284$ & $13 \%$ & $\$ 610$ & $21 \%$ & $\$ 259$ & $12 \%$ & $\$ 225$ & $11 \%$ & $\$ 266$ & $11 \%$ \\
\hline Total Cost & $\$ 2,434$ & & $\$ 2,432$ & & $\$ 2,220$ & & $\$ 2,838$ & & $\$ 2,239$ & & $\$ 2,119$ & & $\$ 2,460$ & \\
\hline
\end{tabular}


Table 3-16b. Nonthermal subsystem costs (\$ millions) and percentages of total costs.

\begin{tabular}{|c|c|c|c|c|c|c|c|c|c|c|}
\hline \multirow[b]{2}{*}{ Subsystems } & \multicolumn{2}{|c|}{$\begin{array}{c}\text { Grout Debris } \\
\text { (NT-1) }\end{array}$} & \multicolumn{2}{|c|}{$\begin{array}{c}\text { Thermal Desorption } \\
\text { (NT-2) }\end{array}$} & \multicolumn{2}{|c|}{$\begin{array}{l}\text { Wash } \\
\text { (NT-3) }\end{array}$} & \multicolumn{2}{|c|}{$\begin{array}{l}\text { Acid Digestion } \\
\text { (NT-4) }\end{array}$} & \multicolumn{2}{|c|}{$\begin{array}{c}\text { Catalyzed Wet } \\
\text { Oxidation } \\
\text { (NT-5) } \\
\end{array}$} \\
\hline & Cost & Percent & Cost & Percent & Cost & Percent & Cost & Percent & Cost & Percen \\
\hline Wash & $\$ 0$ & $0 \%$ & $\$ 0$ & $0 \%$ & $\$ 214$ & $6 \%$ & $\$ 153$ & $4 \%$ & $\$ 153$ & $4 \%$ \\
\hline Total Primary Treatment & $\$ 380$ & $10 \%$ & $\$ 334$ & $9 \%$ & $\$ 460$ & $12 \%$ & $\$ 671$ & $17 \%$ & $\$ 676$ & $18 \%$ \\
\hline Aqueous Waste & $\$ 150$ & $4 \%$ & $\$ 150$ & $4 \%$ & $\$ 150$ & $4 \%$ & $\$ 150$ & $4 \%$ & $\$ 150$ & $4 \%$ \\
\hline Special Waste & $\$ 46$ & $1 \%$ & $\$ 46$ & $1 \%$ & $\$ 46$ & $1 \%$ & $\$ 46$ & $1 \%$ & $\$ 46$ & $1 \%$ \\
\hline Certification \& Shipping & $\$ 499$ & $13 \%$ & $\$ 491$ & $13 \%$ & $\$ 514$ & $14 \%$ & $\$ 420$ & $11 \%$ & $\$ 424$ & $11 \%$ \\
\hline Administration \& Support & $\$ 254$ & $7 \%$ & $\$ 250$ & $7 \%$ & $\$ 254$ & $7 \%$ & $\$ 256$ & $7 \%$ & $\$ 254$ & $7 \%$ \\
\hline Disposal & $\$ 833$ & $22 \%$ & $\$ 827$ & $23 \%$ & $\$ 799$ & $21 \%$ & $\$ 737$ & $19 \%$ & $\$ 707$ & $19 \%$ \\
\hline Total Cost & $\$ 3,722$ & & $\$ 3,658$ & & $\$ 3,791$ & & $\$ 3,877$ & & $\$ 3,817$ & \\
\hline
\end{tabular}


Table 3-17a. Thermal capital costs ( $\$$ millions) by subsystem and percentages of capital costs.

\begin{tabular}{|c|c|c|c|c|c|c|c|c|c|c|c|c|c|c|}
\hline \multirow[b]{2}{*}{ Subsystems } & \multicolumn{2}{|c|}{$\begin{array}{c}\text { Rotary Kiln/Air } \\
\text { (A-1) }\end{array}$} & \multicolumn{2}{|c|}{$\begin{array}{c}\text { Rotary } \\
\text { Kiln/Oxygen } \\
\text { (A-2) }\end{array}$} & \multicolumn{2}{|c|}{$\begin{array}{c}\text { Slagging } \\
\text { Rotary Kiln } \\
(\mathrm{A}-7) \\
\end{array}$} & \multicolumn{2}{|c|}{$\begin{array}{c}\text { Rotary } \\
\text { Kiln/Grout } \\
\text { (A-8) }\end{array}$} & \multicolumn{2}{|c|}{$\begin{array}{c}\text { Plasma Furnace } \\
\text { (C-1) }\end{array}$} & \multicolumn{2}{|c|}{$\begin{array}{c}\text { Metal Melter } \\
(\text { G-1) }\end{array}$} & \multicolumn{2}{|c|}{$\begin{array}{c}\text { Steam } \\
\text { Reforming } \\
(\mathrm{H}-1)\end{array}$} \\
\hline & Cost & Percent & Cost & Percent & Cost & Percent & Cost & Percent & Cost & Percent & Cost & Percent & Cost & Percent \\
\hline Front-End Handling & $\$ 117$ & $21 \%$ & $\$ 117$ & $22 \%$ & $\$ 112$ & $24 \%$ & $\$ 117$ & $23 \%$ & $\$ 112$ & $25 \%$ & $\$ 100$ & $22 \%$ & $\$ 136$ & $23 \%$ \\
\hline Organic Destruction & $\$ 42$ & $8 \%$ & $\$ 44$ & $8 \%$ & $\$ 75$ & $16 \%$ & $\$ 42$ & $8 \%$ & $\$ 78$ & $17 \%$ & $\$ 95$ & $21 \%$ & $\$ 67$ & $11 \%$ \\
\hline Thermal Desorption & $\$ 0$ & $0 \%$ & $\$ 0$ & $0 \%$ & $\$ 0$ & $0 \%$ & $\$ 0$ & $0 \%$ & $\$ 0$ & $0 \%$ & $\$ 0$ & $0 \%$ & $\$ 0$ & $0 \%$ \\
\hline Wash & $\$ 0$ & $0 \%$ & $\$ 0$ & $0 \%$ & $\$ 0$ & $0 \%$ & $\$ 0$ & $0 \%$ & $\$ 0$ & $0 \%$ & $\$ 0$ & $0 \%$ & $\$ 0$ & $0 \%$ \\
\hline Total Primary Treatment & $\$ 42$ & $8 \%$ & $\$ 44$ & $8 \%$ & $\$ 75$ & $16 \%$ & $\$ 42$ & $8 \%$ & $\$ 78$ & $17 \%$ & $\$ 95$ & $21 \%$ & $\$ 67$ & $11 \%$ \\
\hline Aqueous Waste & $\$ 22$ & $4 \%$ & $\$ 22$ & $4 \%$ & $\$ 21$ & $4 \%$ & $\$ 22$ & $4 \%$ & $\$ 22$ & $5 \%$ & $\$ 17$ & $4 \%$ & $\$ 17$ & $3 \%$ \\
\hline Air Pollution Control & $\$ 39$ & $7 \%$ & $\$ 19$ & $4 \%$ & $\$ 38$ & $8 \%$ & $\$ 39$ & $8 \%$ & $\$ 22$ & $5 \%$ & $\$ 34$ & $8 \%$ & $\$ 30$ & $5 \%$ \\
\hline Stabilization & $\$ 116$ & $21 \%$ & $\$ 116$ & $22 \%$ & $\$ 48$ & $10 \%$ & $\$ 75$ & $15 \%$ & $\$ 49$ & $11 \%$ & $\$ 49$ & $11 \%$ & $\$ 116$ & $20 \%$ \\
\hline Metal Recovery & $\$ 94$ & $17 \%$ & $\$ 94$ & $18 \%$ & $\$ 52$ & $11 \%$ & $\$ 94$ & $18 \%$ & $\$ 52$ & $11 \%$ & $\$ 27$ & $6 \%$ & $\$ 94$ & $16 \%$ \\
\hline Special Waste & $\$ 9$ & $2 \%$ & $\$ 9$ & $2 \%$ & $\$ 9$ & $2 \%$ & $\$ 9$ & $2 \%$ & $\$ 9$ & $2 \%$ & $\$ 9$ & $2 \%$ & $\$ 9$ & $2 \%$ \\
\hline Certification \& Shipping & $\$ 45$ & $8 \%$ & $\$ 45$ & $8 \%$ & $\$ 45$ & $9 \%$ & $\$ 45$ & $9 \%$ & $\$ 45$ & $10 \%$ & $\$ 45$ & $10 \%$ & $\$ 45$ & $8 \%$ \\
\hline Administration \& Support & $\$ 70$ & $13 \%$ & $\$ 70$ & $13 \%$ & $\$ 74$ & $16 \%$ & $\$ 70$ & $14 \%$ & $\$ 70$ & $15 \%$ & $\$ 74$ & $16 \%$ & $\$ 74$ & $13 \%$ \\
\hline Total Capital Cost & $\$ 554$ & & $\$ 536$ & & $\$ 474$ & & $\$ 514$ & & $\$ 459$ & & $\$ 450$ & & $\$ 588$ & \\
\hline
\end{tabular}


Table 3-17b. Nonthermal capital costs ( $\$$ millions) by subsystem and percentages of capital costs.

\begin{tabular}{|c|c|c|c|c|c|c|c|c|c|c|}
\hline \multirow[b]{2}{*}{ Subsystems } & \multicolumn{2}{|c|}{$\begin{array}{c}\text { Grout Debris } \\
\text { (NT-1) }\end{array}$} & \multicolumn{2}{|c|}{$\begin{array}{c}\text { Thermal Desorption } \\
\text { (NT-2) }\end{array}$} & \multicolumn{2}{|c|}{$\begin{array}{l}\text { Wash } \\
\text { (NT-3) }\end{array}$} & \multicolumn{2}{|c|}{$\begin{array}{c}\text { Acid Digestion } \\
(\mathrm{NT}-4)\end{array}$} & \multicolumn{2}{|c|}{$\begin{array}{c}\text { Catalyzed Wet } \\
\text { Oxidation } \\
\text { (NT-5) }\end{array}$} \\
\hline & Cost & Percent & Cost & Percent & Cost & Percent & Cost & Percent & Cost & Percen \\
\hline Front-End Handling & $\$ 173$ & $29 \%$ & $\$ 173$ & $31 \%$ & $\$ 173$ & $27 \%$ & $\$ 173$ & $26 \%$ & $\$ 173$ & $26 \%$ \\
\hline Organic Destruction & $\$ 67$ & $11 \%$ & $\$ 33$ & $6 \%$ & $\$ 67$ & $11 \%$ & $\$ 74$ & $11 \%$ & $\$ 80$ & $12 \%$ \\
\hline Thermal Desorption & $\$ 42$ & $7 \%$ & $\$ 42$ & $7 \%$ & & & $\$ 42$ & $6 \%$ & $\$ 42$ & $6 \%$ \\
\hline Wash & & & & & $\$ 73$ & $11 \%$ & $\$ 61$ & $9 \%$ & $\$ 61$ & $9 \%$ \\
\hline Total Primary Treatment & $\$ 109$ & $18 \%$ & $\$ 75$ & $13 \%$ & $\$ 140$ & $22 \%$ & $\$ 176$ & $26 \%$ & $\$ 183$ & $27 \%$ \\
\hline Aqueous Waste & $\$ 32$ & $5 \%$ & $\$ 32$ & $6 \%$ & $\$ 32$ & $5 \%$ & $\$ 32$ & $5 \%$ & $\$ 32$ & $5 \%$ \\
\hline Air Pollution Control & $\$ 21$ & $3 \%$ & $\$ 21$ & $4 \%$ & $\$ 21$ & $3 \%$ & $\$ 21$ & $3 \%$ & $\$ 21$ & $3 \%$ \\
\hline Stabilization & $\$ 103$ & $17 \%$ & $\$ 103$ & $18 \%$ & $\$ 103$ & $16 \%$ & $\$ 113$ & $17 \%$ & $\$ 103$ & $15 \%$ \\
\hline Metal Recovery & $\$ 33$ & $5 \%$ & $\$ 33$ & $6 \%$ & $\$ 33$ & $5 \%$ & $\$ 33$ & $5 \%$ & $\$ 33$ & $5 \%$ \\
\hline Special Waste & $\$ 9$ & $2 \%$ & $\$ 9$ & $2 \%$ & $\$ 9$ & $1 \%$ & $\$ 9$ & $1 \%$ & $\$ 9$ & $1 \%$ \\
\hline Certification \& Shipping & $\$ 64$ & $11 \%$ & $\$ 61$ & $11 \%$ & $\$ 64$ & $10 \%$ & $\$ 58$ & $9 \%$ & $\$ 58$ & $9 \%$ \\
\hline Administration \& Support & $\$ 57$ & $10 \%$ & $\$ 54$ & $10 \%$ & $\$ 57$ & $9 \%$ & $\$ 59$ & $9 \%$ & $\$ 57$ & $9 \%$ \\
\hline Total Capital Cost & $\$ 600$ & & $\$ 561$ & & $\$ 632$ & & $\$ 673$ & & $\$ 668$ & \\
\hline
\end{tabular}




\subsubsection{Receiving and Preparation}

All the waste entering the treatment facility passes through the receiving and preparation (front-end handling) subsystem for characterization, sorting, and initial size reduction. As indicated in Table 3-16, this subsystem has the highest cost for both thermal and nonthermal systems, using of 25 to $30 \%$ of the total expenditure. This subsystem has the highest personnel requirements (see Table 3-14) and the highest capital costs (see Table 3-17) for the equipment and facility to house the operation. Receiving and preparation costs for nonthermal systems are about $40 \%$ higher than for thermal systems due to the increased need for sorting and routing to the appropriate treatment process. Receiving and preparation cost for System H-1 (steam gasification) is slightly higher than for the other thermal systems because of the need to separate combustible material from the noncombustible.

The major uncertainty in the receiving and preparation subsystem is the ability to adequately separate the waste to prevent upset conditions in the treatment processes. The preconceptual design assumption in the ITTS and INTS studies was that automated methods for characterization are available, and robotic and/or remote sorting would be used. However, extensive development and testing will be required for these concepts to be implemented, and the methods currently used in industry, manual sampling and sorting, can greatly increase the estimated costs and risk to workers. Because nonthermal systems require more detailed characterization and sorting, their costs may escalate more than the costs for thermal systems.

\subsubsection{Primary Treatment}

Primary treatment consists of the unit operations or technologies that treat the majority of the waste entering the facility. Thermal systems are relatively simple in that primary treatment uses one main thermal treatment process (or two unit operations in the case of steam gasification System H-1) and the organic waste and organic contaminants on the inorganic waste are destroyed in essentially one operation. In contrast, nonthermal systems require removal of the organic contaminants from the inorganic matrices to facilitate destruction by chemical oxidation. Removal is accomplished by vacuum thermal desorption or several washing processes, depending on the characteristics of the solid matrices. Thus, nonthermal primary treatment consists of organic separation followed by organic destruction.

The largest input to thermal primary treatment units is fuel and air (or oxygen), followed by waste and then soil to form a glass in the vitrifier. The exceptions are those systems that do not require a combustion process to generate heat. The output from the thermal primary treatment consists of a gaseous effluent, which is treated in the APC system before discharge; aqueous waste resulting from the quench and scrubber processes, which is treated in the aqueous treatment system before recycle or discharge; and ash, which is stabilized by vitrification. The input and effluent from the primary treatment systems are shown in Table 3-18 and the figures in Section 2.

For nonthermal systems, the major input to the primary treatment process is the waste, process chemicals, and wash water. The output from the nonthermal systems includes a gaseous effluent treated in the APC system before discharge; an aqueous effluent treated in the aqueous treatment system before recycle or discharge, and the treated solids that are stabilized for disposal.

The greater complexity of nonthermal systems, and the increased number of unit operations, requires more operating personnel (as shown in Table 3-14) and has a higher capital cost, which lead to a higher system life-cycle cost. These costs also reflect the lower maturity and, therefore, higher research and development costs associated with nonthermal treatment. Nonthermal systems NT -4 and NT-5 have the 
Table 3-18a. Mass balance for the thermal primary treatment subsystem (lbs $/ \mathrm{hr}$ ).

\begin{tabular}{|c|c|c|c|c|c|c|c|}
\hline $\begin{array}{c}\text { Input and Output } \\
\text { Streams }\end{array}$ & $\begin{array}{c}\text { Rotary } \\
\text { Kiln/Air } \\
\text { (A-1) }\end{array}$ & $\begin{array}{c}\text { Rotary } \\
\text { Kiln/Oxygen } \\
(\mathrm{A}-2)\end{array}$ & $\begin{array}{c}\text { Slagging } \\
\text { Rotary Kiln } \\
(\mathrm{A}-7) \\
\end{array}$ & $\begin{array}{c}\text { Rotary } \\
\text { Kiln/Grout } \\
\text { (A-8) }\end{array}$ & $\begin{array}{c}\text { Plasma } \\
\text { Furnace } \\
(\mathrm{C}-1) \\
\end{array}$ & $\begin{array}{c}\text { Metal Melter } \\
(\mathrm{G}-1)\end{array}$ & $\begin{array}{c}\text { Steam } \\
\text { Reforming } \\
(\mathrm{H}-\mathrm{l}) \\
\end{array}$ \\
\hline \multicolumn{8}{|l|}{ Input Streams } \\
\hline Combustible Waste & 660 & 660 & 660 & 660 & 660 & 660 & 660 \\
\hline Noncombustible Waste & 1340 & 1340 & 1340 & 1340 & 1340 & 1340 & \\
\hline Metal & 0 & 0 & 149 & & 149 & 617 & \\
\hline Soil & 498 & 498 & 564 & & 482 & 524 & \\
\hline Water & 482 & 1824 & & 656 & & & 446 \\
\hline Fuel and Air & 19636 & 5321 & 26116 & 19748 & 6240 & 79 & \\
\hline Flyash from APC & & & 423 & & 88 & 383 & \\
\hline Flux & & & & & & 48 & \\
\hline Total Input & 22616 & 9643 & 29252 & 22404 & 8959 & 3651 & 1106 \\
\hline \multicolumn{8}{|l|}{ Output Streams } \\
\hline Bottom Ash & 1196 & 1196 & & 861 & & & 150 \\
\hline Offgas to APC & 21420 & 8448 & 27561 & 21543 & 7339 & 1467 & 957 (Syngas) \\
\hline Cast Metal & & & & & 170 & 613 & \\
\hline Slag & & & 1691 & & 1450 & 1572 & \\
\hline Total Output & 22616 & 9644 & 29252 & 22404 & 8959 & 3652 & \\
\hline
\end{tabular}


Table 3-18b. Mass balance for the nonthermal primary treatment subsystem (lbs/hr).

\begin{tabular}{|c|c|c|c|c|c|}
\hline Input and Output Streams & $\begin{array}{c}\text { Grout Debris } \\
\text { (NT-1) }\end{array}$ & $\begin{array}{c}\text { Thermal } \\
\text { Desorption } \\
\text { (NT-2) }\end{array}$ & $\begin{array}{c}\text { Wash } \\
\text { (NT-3) }\end{array}$ & $\begin{array}{c}\text { Acid Digestion } \\
(\mathrm{NT}-4)\end{array}$ & $\begin{array}{c}\text { Catalyzed Wet } \\
\text { Oxidation } \\
\text { (NT-5) }\end{array}$ \\
\hline \multicolumn{6}{|l|}{ Input to Thermal Desorber } \\
\hline Process Residue & 1007.2 & 1007.2 & & 1007.2 & 1007.2 \\
\hline Soils & 328.5 & 328.5 & & & \\
\hline Lead recovery Sludge & 13 & 13 & & 13 & 13 \\
\hline Debris & & 692.6 & & & \\
\hline Sweep Gas & 106 & 160.9 & & 80 & 80 \\
\hline Water to Mercury Leach & 404.6 & 612.5 & & 306 & 306 \\
\hline Total Input & 1859.3 & 2814.7 & & 1406.2 & 1406.2 \\
\hline \multicolumn{6}{|l|}{ Output from Thermal Desorber } \\
\hline Sludge to Polymer or Ceramic & 959.5 & 953.9 & & 953.9 & 953.9 \\
\hline Condensate to Organic Destruct & 18.6 & 51.3 & & 22.6 & 22.6 \\
\hline Condensate to Aqueous Treatment & 390.3 & 422.7 & & 349.6 & 349.6 \\
\hline Offgas to APC & 106 & 161.2 & & 79.9 & 79.9 \\
\hline Soils and/or Debris to Grout & 384.8 & 1223 & & & \\
\hline Hg to Amalgamation & 0.1 & 2.6 & & 0.1 & 0.1 \\
\hline Total Output & 1859.3 & 2814.7 & & 1406.1 & 1406.1 \\
\hline \multicolumn{6}{|l|}{ Input to Organic Destruct } \\
\hline Organic Waste Input & 185.4 & 185.4 & 185.4 & 185.4 & 185.4 \\
\hline Organics from Aqueous Waste & 32.9 & 31.5 & 79.1 & 31.9 & 31.9 \\
\hline Desorber Condensate & 18.6 & 51.3 & & 22.6 & 22.6 \\
\hline Process Chemicals & 691.1 & 786.3 & 972.8 & 1640.4 & 1559 \\
\hline Organics from Wash & & & 61.5 & 16.1 & 16.1 \\
\hline Soft debris & & & & 434.8 & 434.8 \\
\hline Total Input & 928 & 1054.5 & 1298.8 & 2331.2 & 2249.8 \\
\hline
\end{tabular}


Table 3-18b. (continued).

\begin{tabular}{lccccc}
\hline \multicolumn{1}{c}{ Input and Output Streams } & $\begin{array}{c}\text { Grout Debris } \\
\text { (NT-1) }\end{array}$ & $\begin{array}{c}\text { Thermal } \\
\text { Desorption } \\
\text { (NT-2) }\end{array}$ & $\begin{array}{c}\text { Wash } \\
\text { (NT-3) }\end{array}$ & $\begin{array}{c}\text { Acid Digestion } \\
\text { (NT-4) }\end{array}$ & $\begin{array}{c}\text { Catalyzed Wet } \\
\text { Oxidation } \\
(\text { NT-5) }\end{array}$ \\
\hline Output from Organic Destruct & & & & & \\
Water \& Salts to Aqueous Waste & 347.5 & 380.3 & 499 & 743.3 & 783.4 \\
Offgas to APC & 580.5 & 652.6 & 799.8 & 1307.2 & 1343.4 \\
Salts to Polymer & & 21.2 & & 180.3 & 23 \\
Residue to Grout & & & & 2330.8 & 2249.2
\end{tabular}

\section{Input to Washing Systems}

Process Residue

\begin{tabular}{cccc}
1007.2 & & 328.5 \\
328.5 & 328.5 & \\
13 & & 80.4 \\
692.6 & 80.4 & 340.5 \\
\hline 583.4 & 340.5 & 749.4
\end{tabular}

\section{Output from Washing Systems}

Sludge \& Water to Polymer

\begin{tabular}{|c|c|c|}
\hline \multirow{2}{*}{\multicolumn{3}{|c|}{1125.9}} \\
\hline & & 16.1 \\
\hline \multirow{4}{*}{484.7} & & \\
\hline & & \\
\hline & & \\
\hline & & \\
\hline & & \\
\hline 61.5 & 16.1 & 16.1 \\
\hline & 365 & 365 \\
\hline & 285.5 & 0 \\
\hline 952.6 & 82.8 & 368.3 \\
\hline 2624.7 & 749.4 & 7494 \\
\hline
\end{tabular}

Organics to Organic Destruct

Water to Aqueous Treatment

Soils to Ceramic

Soils and Debris to Grout

Total Output

2624.7

749.4 
highest capital cost due to the added equipment for destruction of soft debris. The nonthermal system with the lowest capital cost is System NT-2 because CWO costs less than the MEO, and thermal desorption requires less equipment than washing. Higher primary treatment costs are also indicated for thermal Systems A-7, C-1 and G-1; these reflect the larger quantity of waste sent to these systems, including metals, and higher capital costs.

Although the primary treatment subsystem is the heart of the treatment systems, it is not the major cost element. Thermal primary treatment processes make up 6 to $17 \%$ of the total system life-cycle cost, including disposal, as shown in Table 3-16. Nonthermal primary treatment processes make up 10 to $18 \%$ of the total system life-cycle cost, including disposal.

The uncertainties associated with the primary treatment systems are their abilities to adequately treat the waste under normal operating conditions and to function, without an accident or release of hazardous material, under off-normal conditions such as inadvertent injection of excess organic material. Rotary kilns have years of operating experience, so their uncertainty is small. However, the performance of innovative systems such as the plasma furnace, metal melter, steam reformer, and the nonthermal systems is less certain.

Vacuum thermal desorption of a variety of organic contaminants from soils has been proven; however, up to $6 \%$ of the contaminants may remain with the solid wastes, making the stability of the nonthermal final waste form less certain. Washing processes may be less capable of removing organic contaminants from the soil and debris, depending on the characteristics of the soil particles, debris surface, and the contaminant. This raises the issue of whether the treated solids can meet the Universal Treatment Standards and whether LDR approval can be obtained for disposal. Chemical destruction processes have been tested with good results on a variety of organic contaminants, but few tests have been performed on the mixtures of organics that may occur on DOE MLLW. Chemical oxidation followed by aqueous waste treatment should be capable of destroying the organic contaminants to the same level as the thermal processes. However, there are still doubts regarding the capability of the processes, as designed, to remove contaminants from the solid matrices.

\subsubsection{Air Pollution Control Systems}

As expected, the principal input to the APC subsystem for thermal treatment systems is the offgas from the primary thermal treatment unit, closely followed by water used for quenching or cooling the offgas and for scrubbing the offgas of acid gases as shown in Table 3-19. The systems that use a reducing environment (Systems G-1 and H-1) also require air to combust the syngas produced in the reduction reaction. The output from the APC systems consists of treated offgas discharged to the environment, scrubber liquor that is treated in the aqueous waste treatment subsystem, and flyash that is stabilized for disposal.

The sources for input to nonthermal APC subsystems include offgas from the chemical oxidation processes, the thermal desorbers, and the aqueous waste treatment subsystems. As with the thermal systems, the sources of the offgas are the unit operations that volatilize the organic contaminants or convert the contaminants to $\mathrm{CO}_{2}$ and water by chemical oxidation. However, because air is not used in the oxidation process, the offgas from these processes is significantly less than the offgas from the thermal treatment units. 
Table 3-19a. Mass balance for the thermal APC subsystems (lbs/hr).

\begin{tabular}{|c|c|c|c|c|c|c|c|}
\hline $\begin{array}{l}\text { Input and Output } \\
\text { Streams }\end{array}$ & $\begin{array}{c}\text { Rotary } \\
\text { Kiln/Air } \\
\text { (A-1) }\end{array}$ & $\begin{array}{c}\text { Rotary } \\
\text { Kiln/Oxygen } \\
\text { (A-2) }\end{array}$ & $\begin{array}{c}\text { Slagging } \\
\text { Rotary Kiln } \\
\text { (A-7) }\end{array}$ & $\begin{array}{c}\text { Rotary } \\
\text { Kiln/Grout } \\
\text { (A-8) }\end{array}$ & $\begin{array}{c}\text { Plasma } \\
\text { Furnace } \\
\text { (C-1) }\end{array}$ & $\begin{array}{l}\text { Metal } \\
\text { Melter } \\
\text { (G-1) }\end{array}$ & $\begin{array}{c}\text { Steam } \\
\text { Reforming } \\
\text { (H-1) }\end{array}$ \\
\hline \multicolumn{8}{|l|}{ Input Streams } \\
\hline Air & & & & & & 10429 & 6000 \\
\hline Water & 12402 & 7071 & 17606 & 12512 & 5730 & 451 & 1704 \\
\hline Caustic & 156 & 156 & 156 & 156 & 156 & 32 & 122 \\
\hline $\begin{array}{l}\text { Offgas from Primary } \\
\text { Thermal Treatment }\end{array}$ & 21420 & 8448 & 27561 & 21543 & 7339 & 1467 & 957 \\
\hline Total Input & 33978 & 15675 & 45323 & 34211 & 13225 & 12379 & 8783 \\
\hline \multicolumn{8}{|l|}{ Output Streams } \\
\hline Offgas Discharge & 20200 & 5377 & 26304 & 20676 & 6762 & 11451 & 7429 \\
\hline $\begin{array}{l}\text { Scrubber Water to } \\
\text { Aqueous Treatment }\end{array}$ & 13474 & 9996 & 18592 & 13317 & 6371 & 541 & 1354 \\
\hline $\begin{array}{l}\text { Flyash to } \\
\text { Stabilization }\end{array}$ & 299 & 299 & 423 & 214 & 88 & 383 & \\
\hline $\begin{array}{l}\text { Trace Metals to } \\
\text { Polymer }\end{array}$ & 4 & 4 & 4 & 4 & 4 & 4 & \\
\hline Total Output & 33977 & 15676 & 45323 & 34211 & 13225 & 12379 & 8783 \\
\hline
\end{tabular}

Table 3-19b. Mass balance for the nonthermal APC subsystems (lbs/hr).

\begin{tabular}{|c|c|c|c|c|c|}
\hline $\begin{array}{c}\text { Input and Output } \\
\text { Streams } \\
\end{array}$ & $\begin{array}{l}\text { Grout } \\
\text { Debris } \\
\text { (NT-1) } \\
\end{array}$ & $\begin{array}{c}\text { Thermal } \\
\text { Desorption } \\
\text { (NT-2) } \\
\end{array}$ & $\begin{array}{l}\text { Wash } \\
\text { (NT-3) }\end{array}$ & $\begin{array}{l}\text { Acid Digestion } \\
\text { (NT-4) }\end{array}$ & $\begin{array}{c}\text { Catalyzed Wet } \\
\text { Oxidation } \\
\text { (NT-5) }\end{array}$ \\
\hline \multicolumn{6}{|l|}{ Input Streams } \\
\hline Air & & & & 45.4 & \\
\hline Water & 0.3 & 1.1 & 2.5 & & 2.9 \\
\hline Caustic & 0.3 & 1.1 & 2.5 & & 2.9 \\
\hline $\begin{array}{l}\text { Offgas from Organic } \\
\text { Destruct }\end{array}$ & 580.5 & 652.6 & 799.8 & 1307.2 & 1343.4 \\
\hline $\begin{array}{l}\text { Offgas from Thermal } \\
\text { Desorber }\end{array}$ & 106 & 161.2 & & 79.9 & 79.9 \\
\hline $\begin{array}{l}\text { Offgas from Aqueous } \\
\text { Treatment }\end{array}$ & 8.8 & 9.1 & 27.1 & 9 & 9.5 \\
\hline Total Input & 695.9 & 825.1 & 831.9 & 1441.5 & 1438.6 \\
\hline \multicolumn{6}{|l|}{ Output Streams } \\
\hline Offgas Discharge & 695.5 & 823 & 827.1 & 1441.4 & 1433.3 \\
\hline $\begin{array}{l}\text { Water \& Salts to } \\
\text { Aqueous Treatment }\end{array}$ & 0.3 & 2 & 5 & 0.1 & 5.2 \\
\hline Total Output & 695.8 & 825 & 832.1 & 1441.5 & 1438.5 \\
\hline
\end{tabular}


The cost of the APC subsystem is a small fraction of the total system cost for both the thermal and nonthermal treatment systems as shown in Table 3-16. The cost of the APC for thermal systems varies from 3 to $5 \%$ of the total life cycle cost; for nonthermal APC subsystems it is about $2 \%$ of the total. The APC subsystems are less than $10 \%$ of the capital cost for thermal systems and less than $5 \%$ of the capital cost for nonthermal systems.

Air pollution control systems have been developed and improved over many years of operation. The thermal and nonthermal APC systems have similar designs, which are expected to lower emissions of toxic substances below regulatory discharge requirements. Differences between the thermal and nonthermal systems include condensers in the nonthermal systems and the gas-phase corona reactor to oxidize the trace levels of volatile organics that may remain after the condensers. Uncertainties about these systems are associated with their ability to treat abnormal quantities of offgas and contaminants resulting from upset or off-normal conditions in the main thermal treatment units.

\subsubsection{Aqueous Waste Treatment Systems}

As shown in Table 3-20, the major input to the thermal aqueous waste treatment subsystems is scrubber water from the APC subsystems, with some additional input from decontamination and rinsing operations. The majority of the output is treated water recycled back to the processes; only excess water is discharged. Two systems (System A-8 and H-1) generate less water than is required and consume less than 2 gpm.

Nonthermal systems require less water than thermal systems, but again most of the water is recycled and only excess is discharged. The primary source of wastewater is desorber condensate, spent organic destruction solution, or wash water. Sludge that is transferred from the wash operations to polymer stabilization contains a large amount of water that is separated from the sludge and sent to aqueous waste treatment.

As with the APC subsystem, aqueous waste treatment is a small fraction of the total system lifecycle cost for both the thermal and nonthermal treatment systems (Table 3-16). For thermal systems, the cost of aqueous waste treatment is about $6 \%$ of the total life-cycle cost, while nonthermal aqueous waste treatment is about $4 \%$ of the total.

Few uncertainties exist with aqueous waste treatment because the operations and processes have been used for many years. UV photooxidation also has been used commercially for treatment of groundwater and wastewaters. Since treatability studies have not been performed, the uncertainties involve assessing the ability of the selected technologies to remove contaminants from the wastewater. In practice, treatability studies would be performed and the system design modified to ensure the water was adequately treated before discharge. Uncertainties associated with UV photooxidation are its ability to treat chlorinated aromatic hydrocarbons and the ability of the pretreatment processes to sufficiently clarify the wastewater so that the UV light can penetrate the water and induce oxidation of the organic contaminants. Chlorinated aromatic organics react very slowly with hydroxyl radicals and require either direct photolysis or a reducing environment for destruction.

\subsubsection{Metal Recovery}

The bulk metal and lead sent to the metal decontamination subsystem, and the water used, is about the same for both thermal and nonthermal systems as shown in Table 3-21. Both use abrasive blasting techniques to clean ferrous metal and lead debris items. In the nonthermal systems, lead items that cannot 
Table 3-20a. Mass balance for the thermal aqueous waste treatment subsystems (lbs/hr).

\begin{tabular}{|c|c|c|c|c|c|c|c|}
\hline $\begin{array}{c}\text { Input and Output } \\
\text { Streams }\end{array}$ & $\begin{array}{c}\text { Rotary } \\
\text { Kiln/Air } \\
(\text { A-1) }\end{array}$ & $\begin{array}{c}\text { Rotary } \\
\text { Kiln/Oxygen } \\
(A-2)\end{array}$ & $\begin{array}{c}\text { Slagging } \\
\text { Rotary Kiln } \\
\text { (A-7) } \\
\end{array}$ & $\begin{array}{c}\text { Rotary } \\
\text { Kiln/Grout } \\
(A-8) \\
\end{array}$ & $\begin{array}{c}\text { Plasma } \\
\text { Furnace } \\
(\mathrm{C}-1)\end{array}$ & $\begin{array}{c}\text { Metal } \\
\text { Melter } \\
\text { (G-1) } \\
\end{array}$ & $\begin{array}{c}\text { Steam } \\
\text { Reforming } \\
(\mathrm{H}-1) \\
\end{array}$ \\
\hline \multicolumn{8}{|l|}{ Input Streams } \\
\hline Aqueous Waste & 80 & 80 & 80 & 80 & 80 & 80 & 80 \\
\hline Process Inputs & 403 & 298 & 556 & 399 & 191 & 16 & 91 \\
\hline $\begin{array}{l}\text { Scrubber Water from } \\
\text { APC }\end{array}$ & 13436 & 9936 & 18537 & 13282.4 & 6346 & 629 & 3044 \\
\hline $\begin{array}{l}\text { Water from Metal } \\
\text { Decontamination }\end{array}$ & 141.7 & 141.7 & 141.7 & 141.7 & 141.7 & 29.7 & 141.7 \\
\hline Total Input & 14061 & 10456 & 19315 & 13903 & 6759 & 755 & 3357 \\
\hline \multicolumn{8}{|l|}{ Output Streams } \\
\hline Recycle & 13549 & 9455 & 18424 & 13828 & 6183 & 555 & 3731 \\
\hline Discharge & 399 & 888 & 778 & -38 & 463 & 87 & -487 \\
\hline Salts to Polymer & 113 & 113 & 113 & 113 & 113 & 113 & 113 \\
\hline Total Output & 14061 & 10456 & 19315 & 13903 & 6759 & 755 & 3357 \\
\hline
\end{tabular}

Table 3-20b. Mass balance for the nonthermal aqueous waste treatment subsystems (lbs/hr).

\begin{tabular}{|c|c|c|c|c|c|}
\hline Input and Output Streams & $\begin{array}{l}\text { Grout Debris } \\
\text { (NT-1) }\end{array}$ & $\begin{array}{l}\text { Thermal } \\
\text { Desorption } \\
\text { (NT-2) }\end{array}$ & $\begin{array}{l}\text { Wash } \\
\text { (NT-3) }\end{array}$ & $\begin{array}{l}\text { Acid } \\
\text { Digestion } \\
(\mathrm{NT}-4)\end{array}$ & $\begin{array}{l}\text { Catalyzed Wet } \\
\text { Oxidation } \\
\text { (NT-5) }\end{array}$ \\
\hline \multicolumn{6}{|l|}{ Input Streams } \\
\hline Aqueous Waste & 60.8 & 60.8 & 60.8 & 60.8 & 60.8 \\
\hline Process Inputs & 52.3 & 96 & 11 & 19.6 & 22.5 \\
\hline Scrubber Water from APC & 0.3 & 2 & 5 & 0.1 & 5.2 \\
\hline $\begin{array}{l}\text { Water from Metal } \\
\text { Decontamination }\end{array}$ & 126.2 & 126.2 & 126.2 & 126.2 & 126.2 \\
\hline Thermal Desorber Condensate & 390.3 & 422.7 & & 349.6 & 349.6 \\
\hline Wash Water & & & 484.7 & 365 & 365 \\
\hline Organic Destruction Solution & 347.5 & 380.3 & 499 & 843.3 & 783.4 \\
\hline Water from Stabilization & 267.5 & 265.7 & 456.7 & 238.3 & 265.5 \\
\hline Total Input & 1244.9 & 1353.7 & 1643.4 & 2002.9 & 1978.2 \\
\hline \multicolumn{6}{|l|}{ Output Streams } \\
\hline Recycle & 1041.8 & 1051.1 & 1247.9 & 1009.9 & 1230.5 \\
\hline Discharge & 59 & 135 & 176 & 780 & 564 \\
\hline Offgas to APC & 8.8 & 9.1 & 27.1 & 9 & 9.5 \\
\hline Salts to Polymer & 102.5 & 127.9 & 113.1 & 172.5 & 142.9 \\
\hline Organics to Organic Destruction & 32.9 & 31.5 & 79.1 & 31.9 & 31.9 \\
\hline Total Output & 1245 & 1354.6 & 1643.2 & 2003.3 & 1978.8 \\
\hline
\end{tabular}


Table 3-21a. Mass balance for the thermal metal decontamination and recovery subsystems (lbs/hr).

\begin{tabular}{|c|c|c|c|c|c|c|c|}
\hline $\begin{array}{l}\text { Input and Output } \\
\text { Streams }\end{array}$ & $\begin{array}{c}\text { Rotary } \\
\text { Kiln/Air } \\
\text { (A-1) }\end{array}$ & $\begin{array}{c}\text { Rotary } \\
\text { Kiln/Oxygen } \\
(\mathrm{A}-2)\end{array}$ & $\begin{array}{c}\text { Slagging } \\
\text { Rotary Kiln } \\
\text { (A-7) }\end{array}$ & $\begin{array}{c}\text { Rotary } \\
\text { Kiln/Grout } \\
\text { (A-8) }\end{array}$ & $\begin{array}{c}\text { Plasma } \\
\text { Furnace } \\
\text { (C-1) }\end{array}$ & $\begin{array}{l}\text { Metal } \\
\text { Melter } \\
\text { (G-1) }\end{array}$ & $\begin{array}{c}\text { Steam } \\
\text { Reforming } \\
\text { (H-1) }\end{array}$ \\
\hline \multicolumn{8}{|c|}{ Input to Metal Decontamination } \\
\hline Bulk Metal & 468 & 468 & 468 & 468 & 468 & & 468 \\
\hline Water & 112 & 112 & 112 & 112 & 112 & & 112 \\
\hline Total Input & 580 & 580 & 580 & 580 & 580 & & 580 \\
\hline \multicolumn{8}{|c|}{ Output from Metal Decontamination } \\
\hline $\begin{array}{l}\text { Clean Metal to } \\
\text { Recycle }\end{array}$ & 463 & 463 & 463 & 463 & 463 & & 463 \\
\hline $\begin{array}{l}\text { Water \& Grit to } \\
\text { Aqueous Treatment }\end{array}$ & 117 & 117 & 117 & 5 & 117 & & 117 \\
\hline Total Output & 580 & 580 & 580 & 580 & 580 & & 580 \\
\hline \multicolumn{8}{|c|}{ Input to Lead Recovery } \\
\hline Lead Waste & 21 & 21 & 21 & 21 & 21 & 21 & 21 \\
\hline Water & 29.7 & 29.7 & 29.7 & 29.7 & 29.7 & 29.7 & 29.7 \\
\hline Total Input & 50.7 & 50.7 & 50.7 & 50.7 & 50.7 & 50.7 & 50.7 \\
\hline \multicolumn{8}{|c|}{ Output from Lead Recovery } \\
\hline Clean Lead & 20 & 20 & 20 & 20 & 20 & 20 & 20 \\
\hline $\begin{array}{l}\text { Water \& Grit to } \\
\text { Aqueous Treatment }\end{array}$ & 30 & 30 & 30 & 30 & 30 & 30 & 30 \\
\hline Total Output & 50 & 50 & 50 & 50 & 50 & 50 & 50 \\
\hline \multicolumn{8}{|c|}{ Input to Metal Melting } \\
\hline $\begin{array}{l}\text { Internally } \\
\text { Contaminated } \\
\text { Metal }\end{array}$ & 149 & 149 & & 149 & & & 149 \\
\hline \multicolumn{8}{|l|}{ Bulk Metal } \\
\hline Lead & 5 & 5 & 5 & 5 & 5 & 5 & 5 \\
\hline Water, Soil \& Flux & 72.3 & 72.3 & 43.3 & 72.3 & 43.3 & 43.3 & 72.3 \\
\hline Air & 46 & 46 & 21 & 46 & 21 & 21 & 46 \\
\hline Total Input & 272.3 & 272.3 & 69.3 & 272.3 & 69.3 & 69.3 & 272.3 \\
\hline \multicolumn{8}{|c|}{ Output from Metal Melting } \\
\hline Clean Metal Ingots & 134 & 134 & & 134 & & & 134 \\
\hline Slag & 23.8 & 23.8 & & 23.8 & 0.8 & 0.8 & 23.8 \\
\hline Lead Ingots & 4.5 & 4.5 & 4.5 & 4.5 & 4.5 & 4.5 & 4.5 \\
\hline $\begin{array}{l}\text { Water to Aqueous } \\
\text { Treatment }\end{array}$ & 29.7 & 29.7 & 29.7 & 29.7 & 29.7 & 29.7 & 29.7 \\
\hline Offigas to APC & 81 & 81 & 35 & 81 & 35 & 35 & 81 \\
\hline Total Output & 273 & 273 & 69.2 & 273 & 70 & 70 & 273 \\
\hline
\end{tabular}


Table 3-21b. Mass balance for the nonthermal metal decontamination and recovery subsystems (lbs/hr).

\begin{tabular}{|c|c|c|c|c|c|}
\hline $\begin{array}{l}\text { Input and Output } \\
\text { Streams }\end{array}$ & $\begin{array}{c}\text { Grout Debris } \\
\text { (NT-1) }\end{array}$ & $\begin{array}{c}\text { Thermal } \\
\text { Desorption } \\
\text { (NT-2) } \\
\end{array}$ & $\begin{array}{l}\text { Wash } \\
\text { (NT-3) }\end{array}$ & $\begin{array}{c}\text { Acid } \\
\text { Digestion } \\
(\mathrm{NT}-4) \\
\end{array}$ & $\begin{array}{c}\text { Catalyzed Wet } \\
\text { Oxidation } \\
\text { (NT-5) }\end{array}$ \\
\hline \multicolumn{6}{|c|}{ Input to Metal Decontamination } \\
\hline Bulk Metal & 462.1 & 462.1 & 462.1 & 462.1 & 462.1 \\
\hline Water & 94.3 & 94.3 & 94.3 & 94.3 & 94.3 \\
\hline \multicolumn{6}{|c|}{ Input to Lead Recovery } \\
\hline Lead Waste & 26 & 26 & 26 & 26 & 26 \\
\hline Water & 13 & 13 & 13 & 13 & 13 \\
\hline Total Input & 595.4 & 595.4 & 595.4 & 595.4 & 595.4 \\
\hline \multicolumn{6}{|c|}{ Output from Metal Decontamination } \\
\hline $\begin{array}{l}\text { Clean Metal to } \\
\text { Recycle }\end{array}$ & 430.3 & 430.3 & 430.3 & 430.3 & 430.3 \\
\hline $\begin{array}{l}\text { Water \& Grit to } \\
\text { Aqueous Treatment }\end{array}$ & 126.2 & 126.2 & 126.2 & 126.2 & 126.2 \\
\hline \multicolumn{6}{|c|}{ Output from Lead Recovery } \\
\hline Clean Lead & 21 & 21 & 21 & 21 & 21 \\
\hline $\begin{array}{l}\text { Sludge to Thermal } \\
\text { Desorption }\end{array}$ & 13 & 13 & & 13 & 13 \\
\hline Sludge to Wash & & & 13 & & \\
\hline Lead to Grout & & 5 & 5 & 5 & 5 \\
\hline Total Output & 595.5 & 595.5 & 595.5 & 595.5 & 595.5 \\
\hline
\end{tabular}

be decontaminated (e.g., lead gloves, aprons) make up a small fraction of the total waste (about $5 \mathrm{lbs} / \mathrm{hr}$ ) and are grouted for disposal in accordance with the debris rule. In thermal systems such lead items are melted and poured into ingots for recycling. An attempt is made in two nonthermal systems (NT-2 and NT-3) to clean internally-contaminated metal debris, but the treated debris is subsequently grouted for disposal. In three systems such metal items are grouted without treatment in accordance with the debris rule. In thermal systems such metal items are melted and poured into ingots for recycling.

The cost of metal recovery is about $10 \%$ of the total life-cycle cost of thermal systems and about $3 \%$ of the life-cycle cost in nonthermal systems. The higher cost for thermal systems is due to the use of metal melters to recover and recycle more of the metal, particularly the internally-contaminated metal that cannot be efficiently decontaminated by nonthermal processes. Metal recovery is also one of the higher capital cost items for thermal systems due to the cost of metal melters and associated facilities. The cost is lower for Systems A-7, C-1, and G-1 because the metal is added to the main thermal treatment process and separate metal melters are not used. In this case, part of the metal melter cost is included in the main thermal treatment unit cost. 


\subsubsection{Stabilization}

Thermal systems use several different methods of stabilization, ranging from producing slag in the main thermal treatment unit, to using a separate vitrifier to produce a slag, to using grout. Table 3-22 shows the primary input to the vitrifiers to be the bottom ash and flyash from the rotary kilns and APC subsystems. In System H-1, inorganic waste, ash from the steam gasifier, and soil are fed directly to the vitrifier. All systems that produce slag as a final waste form generate about the same amount, 1500 to $1700 \mathrm{lbs} / \mathrm{hr}$ depending on whether or not metal is added to the main thermal treatment unit (as in Systems A-7, C-1, and G-1). System A-8 uses grout as the final waste form, yielding a mass about twice the mass of slag. Since grout has a lower density than slag, the volume will be about three times the volume of slag.

All waste from the nonthermal primary treatment systems is stabilized, including salts, soils, debris, sludges, and internally-generated sludges from the aqueous waste treatment and organic destruction subsystems. Nonthermal systems, which use grout, polymer, or phosphate-bonded ceramic, produce about 2 to 3 times the mass of stabilized waste and over three times the volume relative to vitrified waste from thermal systems.

Stabilization costs for thermal systems vary from a high of $15 \%$ for systems that use a separate vitrifier to a low of $6 \%$ for systems that produce slag in the thermal treatment unit or use grout. For systems that use a separate vitrifier, stabilization is the second highest life-cycle cost element - even higher than disposal. Vitrifiers are also one of the higher capital cost items for the systems that use separate vitrifiers (Systems A-1, A-2,. And H-1), as indicated in Table 3-17. In nonthermal systems, stabilization by grout, polymer, or ceramic is about $12 \%$ of the total system life-cycle cost (Table 3-16). Because of the high waste volume, nonthermal disposal costs are significantly higher than costs for disposing thermallystabilized waste. Disposal costs for nonthermally-generated final waste forms are about 20 to $23 \%$ of the total system life-cycle costs, whereas disposal costs for vitrified wastes are about $11 \%$ of the total system life-cycle costs.

The uncertainties associated with stabilization include the long-term stability of the final waste form, particularly the stability of grouted waste that contains relatively high levels of organic contaminants. The waste characterization needs for determining the additives required to form an adequate vitrified waste form are also uncertain.

\subsection{System Life-Cycle Costs}

Total system life-cycle cost as a function of the work breakdown elements is shown in Table 3-23 and Figure 3-13. All costs include $25 \%$ contingency, although it could be argued that the contingency should be higher for systems using less developed technologies. The effect of contingency on cost has been evaluated in another report. ${ }^{7}$ The six cost components of the work breakdown structure are as follows:

1. Studies and Bench-Scale Tests. Costs for studies and bench-scale testing include research personnel, equipment, facilities, and project management before Title I design.

2. Demonstration. Demonstration costs include personnel, design and inspection, construction, and equipment, including construction management and project management. 
Table 3-22a. Mass balance for the thermal stabilization subsystems (lbs/hr).

\begin{tabular}{|c|c|c|c|c|c|c|c|}
\hline $\begin{array}{l}\text { Input and Output } \\
\text { Streams }\end{array}$ & $\begin{array}{c}\text { Rotary } \\
\text { Kiln/Air } \\
\text { (A-1) }\end{array}$ & $\begin{array}{c}\text { Rotary } \\
\text { Kiln/Oxygen } \\
(\mathrm{A}-2) \\
\end{array}$ & $\begin{array}{c}\text { Slagging } \\
\text { Rotary Kiln } \\
(\mathrm{A}-7)\end{array}$ & $\begin{array}{c}\text { Rotary } \\
\text { Kiln/Grout } \\
\text { (A-8) }\end{array}$ & $\begin{array}{c}\text { Plasma } \\
\text { Furnace } \\
\text { (C-1) }\end{array}$ & $\begin{array}{l}\text { Metal } \\
\text { Melter } \\
(\mathrm{G}-1)\end{array}$ & $\begin{array}{c}\text { Steam } \\
\text { Reforming } \\
(\mathrm{H}-1)\end{array}$ \\
\hline \multicolumn{8}{|l|}{ Input to Vitrifier } \\
\hline Inorganic Waste & & & & & & & 1340 \\
\hline Bottom Ash & 1196 & 1196 & & & & & 150 \\
\hline Flyash & 299 & 299 & & & & & \\
\hline Soil & & & & & & & 498 \\
\hline Water \& Caustic & 91 & 91 & & & & & 1262 \\
\hline Fuel \& Air & 227 & 227 & & & & & 704 \\
\hline Total Input & 1813 & 1813 & & & & & 3954 \\
\hline \multicolumn{8}{|c|}{ Output from Vitrifier } \\
\hline Slag & 1495 & 1495 & & & & & 1493 \\
\hline Offgas & 319 & 319 & & & & & 754 \\
\hline $\begin{array}{l}\text { Trace Metals to } \\
\text { Polymer }\end{array}$ & & & & & & & 4 \\
\hline \multicolumn{8}{|l|}{$\begin{array}{l}\text { Scrubber water } \\
\text { to Aqueous } \\
\text { Treatment }\end{array}$} \\
\hline Total Output & 1814 & 1814 & & & & & 3953 \\
\hline \multicolumn{8}{|c|}{ Input to Grout Stabilization } \\
\hline $\begin{array}{l}\text { Lead Recovery } \\
\text { Sludge }\end{array}$ & 0.3 & 0.3 & 0.3 & 0.3 & 0.3 & 0.3 & 0.3 \\
\hline Ash & & & & 1075 & & & \\
\hline Grout Material & 0.6 & 0.6 & 0.6 & 2150.6 & 0.6 & 0.6 & 0.6 \\
\hline $\begin{array}{l}\text { Stabilized } \\
\text { Product }\end{array}$ & 0.9 & 0.9 & 0.9 & 3225.9 & 0.9 & 0.9 & 0.9 \\
\hline \multicolumn{8}{|c|}{ Input to Polymer Stabilization } \\
\hline Waste Salts & 1 & 1 & 1 & 1 & 1 & 1 & 1 \\
\hline $\begin{array}{l}\text { Aqueous Waste } \\
\text { Sludge }\end{array}$ & 113 & 113 & 113 & 113 & 113 & 23 & 113 \\
\hline $\begin{array}{l}\text { Trace Metals } \\
\text { from APC }\end{array}$ & 4 & 4 & 4 & 4 & 4 & 4 & 4 \\
\hline $\begin{array}{l}\text { Metal } \\
\text { Decontamination } \\
\text { Residue }\end{array}$ & 5 & 5 & 5 & 5 & 5 & & 5 \\
\hline Polymer & 123 & 123 & 123 & 123 & 123 & 28 & 123 \\
\hline Total Input & 246 & 246 & 246 & 246 & 246 & 56 & 246 \\
\hline $\begin{array}{c}\text { Stabilized } \\
\text { Product }\end{array}$ & 246 & 246 & 246 & 246 & 246 & 56 & 246 \\
\hline
\end{tabular}


Table 3-22b. Mass balance for the nonthermal stabilization subsystems (lbs/hr).

\begin{tabular}{|c|c|c|c|c|c|}
\hline $\begin{array}{c}\text { Input and } \\
\text { Output Streams }\end{array}$ & $\begin{array}{c}\text { Grout Debris } \\
\text { (NT-1) }\end{array}$ & $\begin{array}{c}\text { Thermal } \\
\text { Desorption } \\
\text { (NT-2) }\end{array}$ & $\begin{array}{l}\text { Wash } \\
\text { (NT-3) }\end{array}$ & $\begin{array}{l}\text { Acid Digestion } \\
\text { (NT-4) }\end{array}$ & $\begin{array}{c}\text { Catalyzed Wet } \\
\text { Oxidation } \\
\text { (NT-5) }\end{array}$ \\
\hline \multicolumn{6}{|c|}{ Input to Grout Stabilization } \\
\hline Waste Debris & 692.6 & & & 177.4 & 177.4 \\
\hline $\begin{array}{l}\text { Treated Debris } \\
\& \text { Residue }\end{array}$ & & 838.2 & 667.5 & 82.8 & 182.2 \\
\hline Soil & 384.8 & 384.8 & 285.5 & & 285.5 \\
\hline Lead & 5 & 5 & 5 & 5 & 5 \\
\hline Grout \& Water & 1831.1 & 1536.4 & 1773.1 & 517.8 & 1287.7 \\
\hline $\begin{array}{l}\text { Stabilized } \\
\text { Product }\end{array}$ & 2913.5 & 2764.4 & 2731.1 & 783 & 1937.8 \\
\hline \multicolumn{6}{|c|}{ Input to Polymer or Ceramic Stabilization } \\
\hline Waste Salts & 6.6 & 6.6 & 6.6 & 6.6 & 6.6 \\
\hline $\begin{array}{l}\text { Inorganic } \\
\text { Sludge }\end{array}$ & 959.5 & 953.9 & 1125.9 & 953.9 & 953.9 \\
\hline $\begin{array}{l}\text { Aqueous } \\
\text { Treatment } \\
\text { Sludge }\end{array}$ & 102.5 & 127.9 & 113.1 & 172.6 & 142.9 \\
\hline $\begin{array}{l}\text { Organic } \\
\text { Destruction } \\
\text { Sludge }\end{array}$ & & 21.2 & & 19.4 & 23 \\
\hline Soil & & & & 285.5 & \\
\hline $\begin{array}{l}\text { Treated Debris } \\
\text { Residue }\end{array}$ & & & & 160.9 & \\
\hline $\begin{array}{l}\text { Polymer or } \\
\mathrm{MgO}\end{array}$ & 801.1 & 843.8 & 788.9 & 1360.6 & 861 \\
\hline Total Input & 1869.7 & 1953.4 & 2034.5 & 2959.5 & 1987.4 \\
\hline \multicolumn{6}{|c|}{ Output from Polymer or Ceramic Stabilization } \\
\hline $\begin{array}{l}\text { Water to } \\
\text { Aqueous } \\
\text { Treatment }\end{array}$ & 267.5 & 265.7 & 456.7 & 238.3 & 265.5 \\
\hline $\begin{array}{l}\text { Stabilized } \\
\text { Product }\end{array}$ & 1602.2 & 1687.6 & 1577.8 & 2721.1 & 1722 \\
\hline Total Output & 1869.7 & 1953.3 & 2034.5 & 2959.4 & 1987.5 \\
\hline
\end{tabular}


Table 3-23a. Thermal system life-cycle costs (\$ millions) and percentage of total costs.

\begin{tabular}{|c|c|c|c|c|c|c|c|c|c|c|c|c|c|c|}
\hline \multirow{2}{*}{$\begin{array}{c}\text { Cost } \\
\text { Components } \\
\end{array}$} & \multicolumn{2}{|c|}{$\begin{array}{l}\text { Rotary Kiln/Air } \\
\text { (A-1) }\end{array}$} & \multicolumn{2}{|c|}{$\begin{array}{c}\text { Rotary } \\
\text { Kiln/Oxygen } \\
(\mathrm{A}-2) \\
\end{array}$} & \multicolumn{2}{|c|}{$\begin{array}{c}\text { Slagging } \\
\text { Rotary Kiln } \\
\text { (A-7) } \\
\end{array}$} & \multicolumn{2}{|c|}{$\begin{array}{c}\text { Rotary } \\
\text { Kiln/Grout } \\
\text { (A-8) } \\
\end{array}$} & \multicolumn{2}{|c|}{$\begin{array}{c}\text { Plasma Furnace } \\
\text { (C-1) }\end{array}$} & \multicolumn{2}{|c|}{$\begin{array}{l}\text { Metal Melter } \\
(\mathrm{G}-1) \\
\end{array}$} & \multicolumn{2}{|c|}{$\begin{array}{c}\text { Steam } \\
\text { Reforming } \\
(\mathrm{H}-1) \\
\end{array}$} \\
\hline & Cost & Percent & Cost & Percent & Cost & Percent & Cost & Percent & Cost & Percent & Cost & Percent & Cost & Percent \\
\hline Test \& Demonstration & $\$ 100$ & $4 \%$ & $\$ 100$ & $4 \%$ & $\$ 100$ & $4 \%$ & $\$ 95$ & $3 \%$ & $\$ 99$ & $4 \%$ & $\$ 88$ & $4 \%$ & $\$ 62$ & $3 \%$ \\
\hline Operations Budget & $\$ 97$ & $4 \%$ & $\$ 97$ & $4 \%$ & $\$ 86$ & $4 \%$ & $\$ 101$ & $4 \%$ & $\$ 90$ & $4 \%$ & $\$ 86$ & $4 \%$ & $\$ 99$ & $4 \%$ \\
\hline Capital & $\$ 554$ & $23 \%$ & $\$ 536$ & $22 \%$ & $\$ 474$ & $21 \%$ & $\$ 514$ & $18 \%$ & $\$ 459$ & $20 \%$ & $\$ 450$ & $21 \%$ & $\$ 588$ & $24 \%$ \\
\hline O\&M & $\$ 1,362$ & $56 \%$ & $\$ 1,379$ & $57 \%$ & $\$ 1,227$ & $55 \%$ & $\$ 1,463$ & $52 \%$ & $\$ 1,283$ & $57 \%$ & $\$ 1,220$ & $58 \%$ & $\$ 1,390$ & $57 \%$ \\
\hline D\&D & $\$ 54$ & $2 \%$ & $\$ 54$ & $2 \%$ & $\$ 49$ & $2 \%$ & $\$ 56$ & $2 \%$ & $\$ 50$ & $2 \%$ & $\$ 50$ & $2 \%$ & $\$ 54$ & $2 \%$ \\
\hline Disposal & $\$ 266$ & $11 \%$ & $\$ 266$ & $11 \%$ & $\$ 284$ & $13 \%$ & $\$ 610$ & $21 \%$ & $\$ 259$ & $12 \%$ & $\$ 225$ & $11 \%$ & $\$ 266$ & $11 \%$ \\
\hline Total & $\$ 2,433$ & & $\$ 2,432$ & & $\$ 2,220$ & & $\$ 2,840$ & & $\$ 2,240$ & & $\$ 2,119$ & & $\$ 2,459$ & \\
\hline Total Without Disposal & $\$ 2,167$ & & $\$ 2,166$ & & $\$ 1,936$ & & $\$ 2,230$ & & $\$ 1,981$ & & $\$ 1,894$ & & $\$ 2,193$ & \\
\hline $\begin{array}{l}\text { Costs Normalized to } \\
\text { System A-8 Without } \\
\text { Disposal }\end{array}$ & 0.97 & & 0.97 & & 0.87 & & 1.00 & & 0.89 & & 0.85 & & 0.98 & \\
\hline $\begin{array}{l}\text { Costs Normalized to } \\
\text { System A-8 With } \\
\text { Disposal }\end{array}$ & 0.86 & & 0.86 & & 0.78 & & 1.00 & & 0.79 & & 0.75 & & 0.87 & \\
\hline $\begin{array}{l}\text { Unit Treatment Costs } \\
\text { Without Disposal }\end{array}$ & $\$ 9.18$ & & $\$ 9.18$ & & $\$ 8.20$ & & $\$ 9.45$ & & $\$ 8.39$ & & $\$ 8.02$ & & $\$ 9.29$ & \\
\hline $\begin{array}{l}\text { Unit Costs With } \\
\text { Disposal }\end{array}$ & $\$ 10.31$ & & $\$ 10.30$ & & $\$ 9.41$ & & $\$ 12.03$ & & $\$ 9.49$ & & $\$ 8.98$ & & $\$ 10.42$ & \\
\hline $\begin{array}{l}\text { Unit Treatment Costs } \\
\text { with Soil Credit and } \\
\text { Without Disposal }\end{array}$ & $\$ 7.85$ & & $\$ 7.84$ & & $\$ 7.01$ & & NA & & $\$ 7.17$ & & $\$ 6.86$ & & $\$ 8.90$ & \\
\hline
\end{tabular}


Table 3-23b. Nonthermal system life-cycle costs (\$ millions) and percentage of total costs.

\begin{tabular}{|c|c|c|c|c|c|c|c|c|c|c|}
\hline \multirow{2}{*}{$\begin{array}{c}\text { Cost } \\
\text { Components }\end{array}$} & \multicolumn{2}{|c|}{$\begin{array}{c}\text { Grout Debris } \\
\text { (NT-1) }\end{array}$} & \multicolumn{2}{|c|}{$\begin{array}{c}\text { Thermal Desorption } \\
\text { (NT-2) }\end{array}$} & \multicolumn{2}{|c|}{$\begin{array}{l}\text { Wash } \\
\text { (NT-3) }\end{array}$} & \multicolumn{2}{|c|}{$\begin{array}{c}\text { Acid Digestion } \\
\text { (NT-4) }\end{array}$} & \multicolumn{2}{|c|}{$\begin{array}{l}\text { Catalyzed Wet } \\
\text { Oxidation } \\
\text { (NT-5) } \\
\end{array}$} \\
\hline & Cost & Percent & Cost & Percent & Cost & Percent & Cost & Percent & Cost & Percent \\
\hline Test \& Demonstration & $\$ 134$ & $4 \%$ & $\$ 142$ & $4 \%$ & $\$ 143$ & $4 \%$ & $\$ 208$ & $5 \%$ & $\$ 167$ & $4 \%$ \\
\hline Operations Budget & $\$ 131$ & $4 \%$ & $\$ 129$ & $4 \%$ & $\$ 135$ & $4 \%$ & $\$ 138$ & $4 \%$ & $\$ 139$ & $4 \%$ \\
\hline Capital & $\$ 600$ & $16 \%$ & $\$ 561$ & $15 \%$ & $\$ 632$ & $17 \%$ & $\$ 673$ & $17 \%$ & $\$ 668$ & $17 \%$ \\
\hline O\&M & $\$ 1,950$ & $52 \%$ & $\$ 1,930$ & $53 \%$ & $\$ 2,005$ & $53 \%$ & $\$ 2,040$ & $53 \%$ & $\$ 2,058$ & $54 \%$ \\
\hline D\&D & $\$ 74$ & $2 \%$ & $\$ 69$ & $2 \%$ & $\$ 77$ & $2 \%$ & $\$ 80$ & $2 \%$ & $\$ 78$ & $2 \%$ \\
\hline Disposal & $\$ 833$ & $22 \%$ & $\$ 827$ & $23 \%$ & $\$ 799$ & $21 \%$ & $\$ 737$ & $19 \%$ & $\$ 707$ & $19 \%$ \\
\hline Total & $\$ 3,722$ & & $\$ 3,658$ & & $\$ 3,791$ & & $\$ 3,876$ & & $\$ 3,817$ & \\
\hline Total Without Disposal & $\$ 2,889$ & & $\$ 2,831$ & & $\$ 2,992$ & & $\$ 3,140$ & & $\$ 3,110$ & \\
\hline $\begin{array}{l}\text { Costs Normalized to } \\
\text { System A-8 Without } \\
\text { Disposal }\end{array}$ & 1.20 & & 1.18 & & 1.24 & & 1.30 & & 1.29 & \\
\hline $\begin{array}{l}\text { Costs Normalized to } \\
\text { System A-8 With } \\
\text { Disposal }\end{array}$ & 1.23 & & 1.21 & & 1.26 & & 1.28 & & 1.27 & \\
\hline $\begin{array}{l}\text { Unit Treatment Costs } \\
\text { Without Disposal }\end{array}$ & $\$ 12.24$ & & $\$ 11.99$ & & $\$ 12.68$ & & $\$ 13.30$ & & $\$ 13.18$ & \\
\hline $\begin{array}{l}\text { Unit Costs With } \\
\text { Disposal }\end{array}$ & $\$ 15.76$ & & $\$ 15.50$ & & $\$ 16.06$ & & $\$ 16.42$ & & $\$ 16.17$ & \\
\hline
\end{tabular}




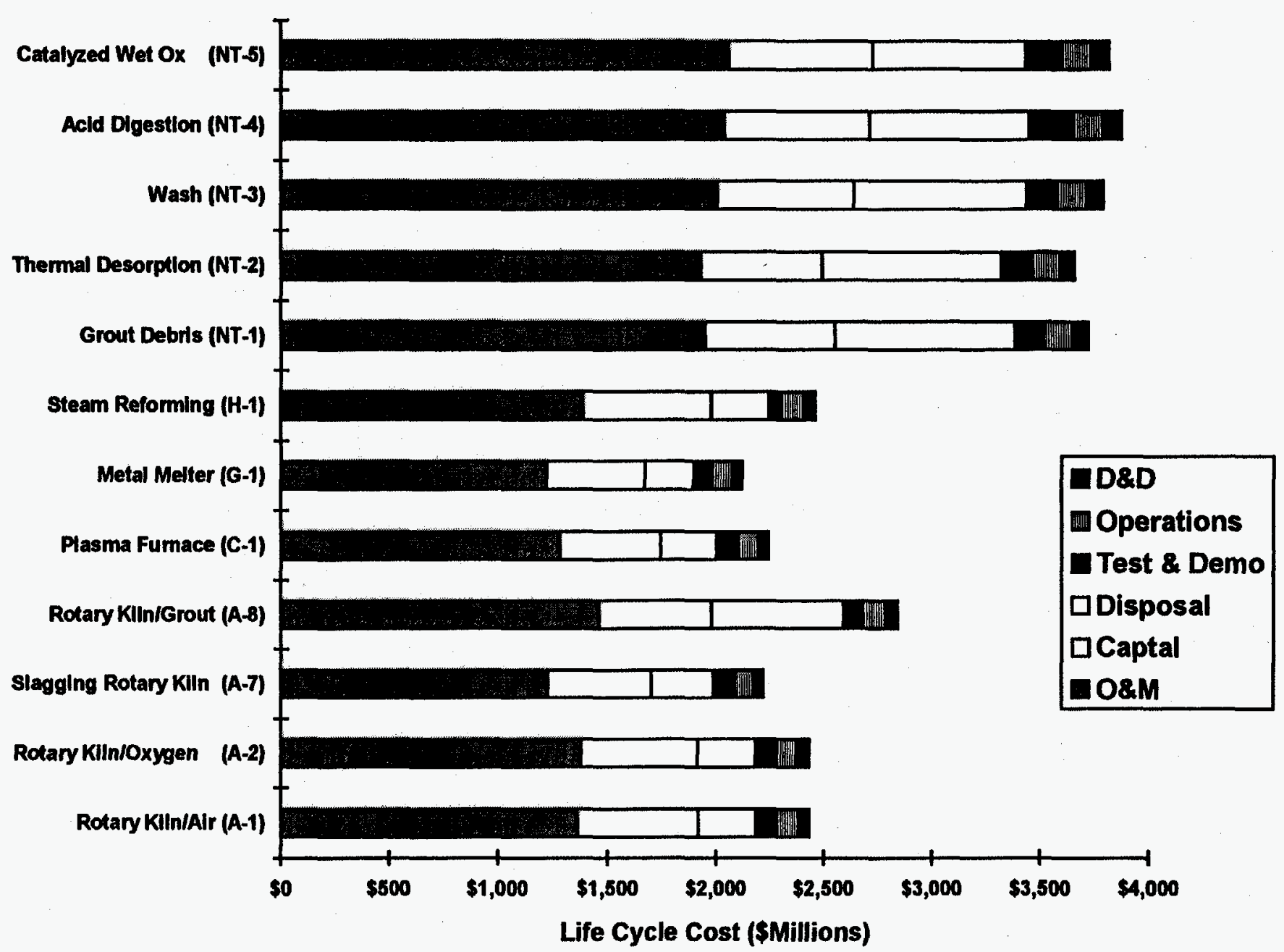

Figure 3-13. Life-cycle costs by work breakdown element. 
3. Facility Capital Costs. This cost element consists of the five subcomponents described below. A breakdown of the capital costs by subsystem is presented in Table 3-17.

- Design. This includes Title 1 , or preliminary, design and Title 2, or detailed, design.

- Inspection. This includes Title 3, or engineering support, during construction.

- Project Management. This includes management costs incurred by DOE and the site management and operations $(\mathrm{M} \& O)$ contractor.

- Construction. Facility construction costs are developed from the preconceptual design package and include site development, construction of buildings and structures for alpha and nonalpha waste, processing and material handling equipment, installation, and indirect costs such as subcontractor overhead and fees.

- Construction Management. This includes material and services procurement and control activities, and allowances for project scope change or management reserve.

4. Operations Budget Funded Activities. This cost element includes conceptual design, safety assurance, National Environmental Policy Act (NEPA) compliance efforts, permitting, preparation for operations, and project management.

5. Operating and Maintenance Costs. This cost element includes operating labor, utilities, consumable materials, maintenance parts and equipment, and maintenance labor.

6. Decontamination and Decommissioning Costs. These costs include decontaminating the facility, removing the structures and equipment, and decontaminating the site.

The major cost element for both thermal and nonthermal systems is operations and maintenance (O\&M), which includes the cost of labor. O\&M is 50 to $60 \%$ of the total system life-cycle cost, and about half the labor is in receiving and preparation as shown in Table 3-14. (As pointed out in the previous section, receiving and preparation is the highest cost subsystem for both thermal and nonthermal systems [25 to $30 \%$ of the total cost, Table 3-16], and appears to be the subsystem in which cost savings could be achieved by improved operations regardless of the treatment technology.) In nonthermal systems, and thermal System A-8, a significant amount of labor is also used in stabilization and in certification and shipping to move the higher volume of final waste to disposal.

The second highest cost element for thermal systems is capital cost at 20 to $25 \%$, followed by disposal cost at $11 \%$ of the total, except for System A-8 in which disposal costs are $20 \%$ of the total slightly higher than capital costs - because of the higher volume of grout. Approximately $\$ 400$ million can be saved by using a thermal system that uses a vitrifier to produce a glass/ceramic final waste form (Systems A-1, A-2, and H-1) instead of using grout stabilization as in System A-8. An additional \$200 million could be saved by using a system that produces a slag waste form as part of the thermal destruction process (Systems A-7, C-1 and G-1).

If contaminated soil were used in place of clean soil or glass additives to form a vitrified final waste form, a 14\% decrease in the unit cost of treatment would be realized. Total cost would remain the same, but additional waste soils from remediation operations would be treated. 
After front-end handling, the next highest subsystem cost for nonthermal systems is disposal, followed by primary treatment and stabilization or certification and shipping, depending on the system. Primary treatment and disposal are about the same for Systems NT -4 and NT-5, about $19 \%$ of the total system cost. Disposal costs for Systems NT-1, NT-2, and NT-3 are over $20 \%$ of the total system cost. Stabilization and certification and shipping are about $12 \%$ of the total cost for all nonthermal systems. Certification and shipping is a significant cost item for nonthermal systems because of the volume of stabilized waste that must be shipped and the personnel required for packaging and shipping.

In absolute terms, total life-cycle costs over a 20 year period of operation are higher for nonthermal systems by approximately $\$ 1$ billion to $\$ 1.5$ billion. O\&M, disposal, and capital costs are all higher for nonthermal systems for the reasons stated previously, namely more personnel, higher disposal volume, and more unit operations and equipment with less maturity. Test and demonstration costs for nonthermal systems are also higher because they are less mature than thermal systems. Because nonthermal systems are less mature and because they require more equipment and unit operations and, therefore, a larger, more complex facility, the operations budget is also higher.

In summary, nonthermal systems are more costly than thermal systems for the following reasons:

- Nonthermal technologies are not as versatile as thermal technologies. Each nonthermal technology has a narrow range of physical material that it can treat. Thus, additional technologies and unit operations are required and more characterization, sorting, and segregating of the waste is required for treatment by the specific technologies.

- The use of more unit operations results in a more physically complex and costly treatment system that requires a larger facility. The more complex facility requires more operations personnel and more maintenance activities, thereby increasing labor costs.

- The nonthermal technologies are less mature and require more demonstration to obtain performance data. The potential need for demonstrating equivalency to the best demonstrated available technology (BDAT), and the uncertainty in permitting requirements also tends to cause the estimated costs of nonthermal systems to be higher than those for thermal systems. This same uncertainty makes the cost estimating uncertain as there are no firm prices for equipment nor do the vendors always know how a commercial installation would be configured. In most cases the INTS study assumed the technology application was at a higher state of development than it actually is.

- The volume of solids going to disposal is about 3 times higher for nonthermal systems than for thermal systems producing a glass-ceramic waste form. Higher volumes of final waste means higher disposal costs and higher labor costs for material handling and packaging in the certification and shipping subsystem.

It must be emphasized that these cost estimates are uncertain, with accuracies of $\pm 30 \%$ for thermal systems, and $+75 \%$ to $-30 \%$ for nonthermal systems. Thus, actual thermal system costs, including disposal, may vary from $\$ 1.7$ to $\$ 3.1$ billion, and nonthermal system costs from $\$ 1$ to $\$ 5$ billion. Within the range of accuracy of these estimates, there may be little or no differentiation between systems, either thermal or nonthermal. 


\subsection{Uncertainties in System Performance}

A large part of the uncertainty comes from lack of maturity of all the nonthermal systems and several thermal systems. An evaluation of the maturity level of these technologies and systems is shown in Figures 3-14 and 3-15. The systems were rated with respect to their estimated level of development as defined in Reference 8 and as summarized below.

- Basic Research: Fundamental research to build core scientific knowledge.

- Applied Research: Beginning to apply knowledge from the previous stage to practical results.

- Exploratory: Experimentation required to evaluate feasibility and develop a product concept. Answers the question "Can the technology be sufficiently developed to solve a problem?"

- Advanced: Laboratory-scale tests have been performed to allow progression from concept to prototype.

- Engineering: Scaled-up prototype has been refined and fabricated to test design features and performance limits resulting in a pilot-scale, field-tested unit.

- Demonstration: The technology has been tested at one or more user sites. If the technology meets required performance specifications, it would be implemented by a user.

- Implementation: Technology has been implemented by a user to treat waste, but implementation depends on the application.

The rotary kilns are the most mature, but system maturity is lowered by the use of a vitrifier. Steam reforming systems are being used for the treatment of municipal solid waste and paper mill sludge. Plasma furnaces have been used in the metals industry, are commercially available for the treatment of municipal and hazardous waste, and have been under development for several years for mixed waste.

Nonthermal systems are the least mature, as none of the organic oxidation processes have been developed beyond the bench-scale level of testing. The catalyzed wet oxidation and MEO processes are farthest along since each is in the pilot-plant design stage and a CWO pilot plant is expected to be operating soon to provide operational data. Vacuum thermal desorbers have been tested on MLLW at the pilot scale with promising results, and UV photooxidation has been applied to the treatment of wastewater and groundwater for several years. Washing processes have been applied to soils contaminated with hazardous waste at Comprehensive Environmental Response, Compensation and Liability Act (CERCLA) sites, and to debris on a limited basis. However, washing has not been applied to the extent assumed in the INTS study. Neither washing nor thermal desorption have been proven to adequately separate organics from sludges. In particular, it is doubtful that these separation processes will be able to achieve the decontamination levels required by the UTSs for all organic contaminants on the various inorganic waste matrices that are in the DOE mixed waste streams. 


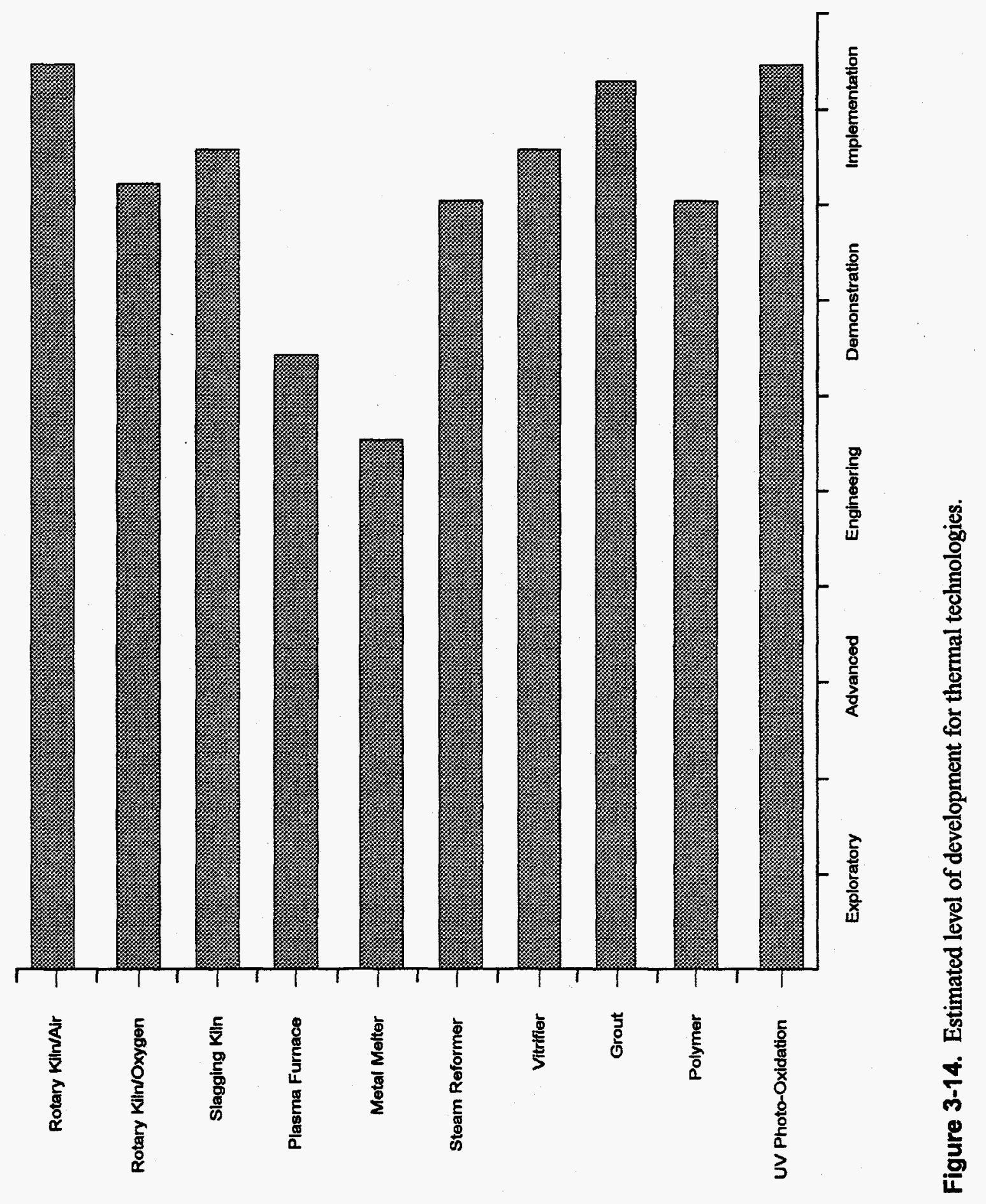




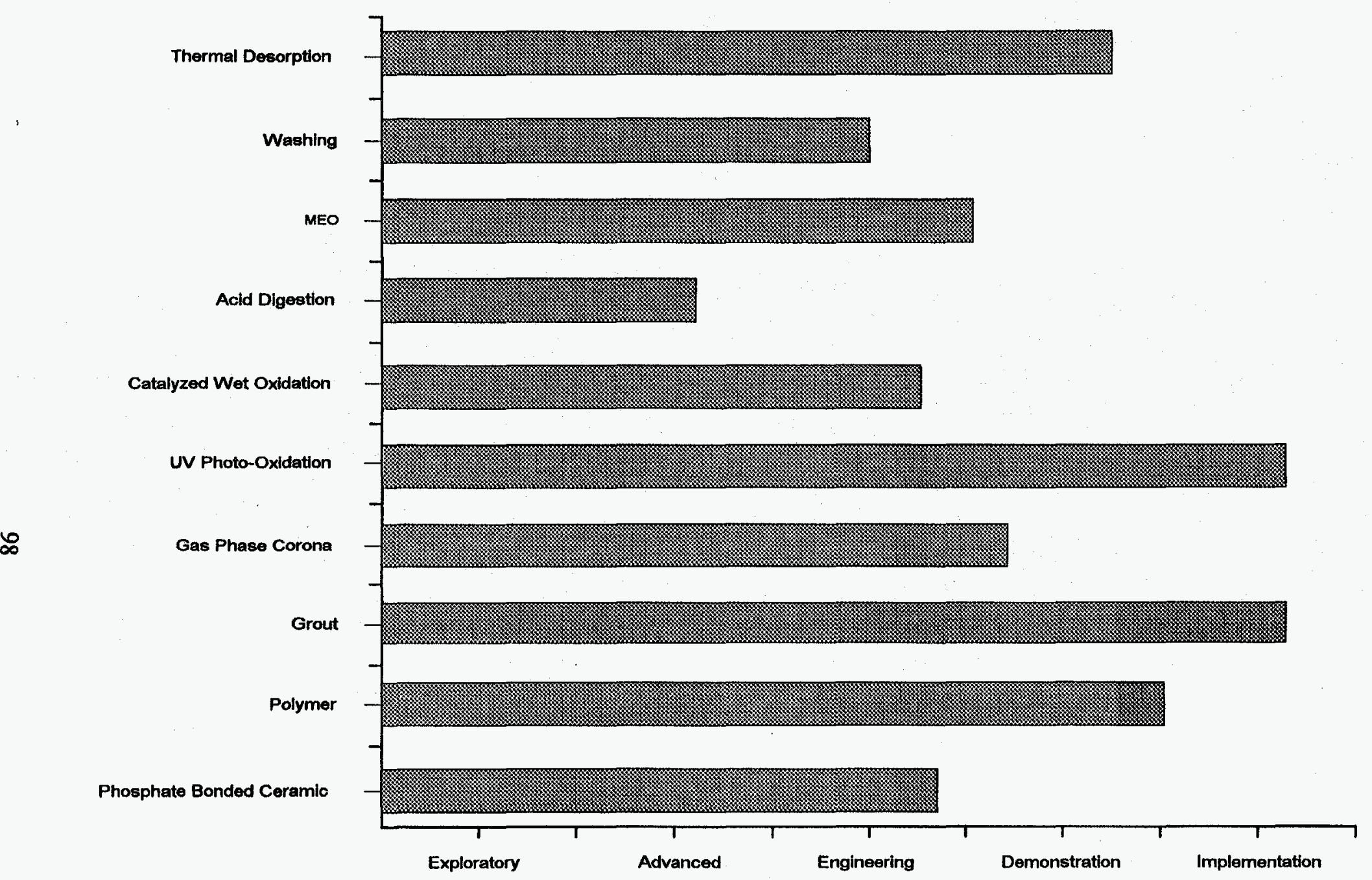

Figure 3-15. Estimated level of development for nonthermal technologies. 
As indicated previously, there are uncertainties in the destruction and removal efficiencies quoted in Section 3.4, and treatability studies on specific waste streams and under specified operating conditions must be performed to evaluate the efficacy of any treatment technology. The regulatory requirements for nonthermal systems is another area of uncertainty. Although most waste streams will be governed by the UTSs, demonstration of equivalency to BDAT may be required for permitting. Uncertainties in the performance of subsystems are identified in Table 3-24.

Regarding final waste forms, some radionuclides have half lives of thousands of years, and heavy metals are toxic forever. As indicated in Section 3.3, there is a relatively high degree of uncertainty in the long-term stability of grout, particularly when immobilizing combustible solids or solids that remain contaminated with organics. Polyethylene is relatively inert and tests have indicated that it should have long-term stability and be highly resistant to leaching. Phosphate-bonded ceramics are new materials, but tests have shown high leach resistance. Slag is similar to geologically stable basalt, which has withstood the elements for millions of years. Although these final waste form materials have passed the EPA tests for immobilizing specific contaminants, there are no tests that can tell us the stability of the waste form and its leach resistance over thousands of years. Thus, the term "long-term stability" may have little meaning with respect to the lifetime of some of these contaminants.

Although thermal systems are generally more mature than nonthermal systems, this does not mean to imply they are ready for implementation. They all require demonstration on MLLW, methods for discharging molten slag need to be developed, refractory life needs to be determined, and even rotary kilns require improvements in their seals to control air leaks. Thus, further development is required for thermal systems to be employed, and significant development work is required for nonthermal systems. The research and development required for thermal and nonthermal systems is discussed in detail in References 2 and 4 . The uncertainties discussed above can be alleviated by treatability studies on the expected MLLW streams, and by performing pilot-level tests to gain operational experience with the systems and equipment.

As indicated earlier, the assumed capabilities of these systems and technologies for the purposes of these studies have not been demonstrated. Although very optimistic performance has been assumed, this should not imply that these systems are ready for deployment.

\subsection{Research and Development Needs}

The uncertainties described in the previous section lead to research and development (R\&D) requirements to minimize these uncertainties and to provide sufficient data for decisions regarding technology development and implementation that meets the expectations of the users and the public. These $R \& D$ needs are both technology specific and system specific in that they relate to combinations of technologies.

Each technology requires its own set of tests and demonstrations to develop the data and information necessary for acceptance by the technical community and by the public for full-scale implementation. The R\&D needs of each of the thermal and nonthermal technologies used in the ITTS and INTS systems analyses are identified and explained in References 1,2 , and 4. The general R\&D needs for subsystems or categories of technologies are identified and discussed in the following sections. 
Table 3-24. Uncertainties in the performance of subsystems.

Vacuum Thermal Desorption

- The ability to maintain the DREs demonstrated during the trial burns with the variations in the DOE wastes.

- The ability to economically characterize waste to ensure staying within the trial burn limits and to verify achievement of the demonstrated DREs.

- The ability to perform continuous emissions monitoring to provide immediate feedback in the event of an upset or off-normal condition so that actions can be taken to prevent release.

- Operational and maintenance requirements for the innovative systems (e.g., Systems C-1, G-1, and H-1).

- Types of byproducts produced and fate of radionuclides and heavy metals in the innovative systems.
- Type and quantity of contaminants (organic, metals, and radionuclides) that are desorbed and that remain with the solids.

- Time and temperature required for desorption of the various contaminants associated with $D O E$ MLLW, and the removal efficiencies for these contaminants.

- The behavior of plastics and other materials that soften and volatilize at elevated temperatures and under vacuum.

- The ability to desorb sludges is undefined and untested, although there is some test data for soils with clay that indicate over $99 \%$ removal efficiency for several volatile organic compounds.

- Ability and/or need to meet Universal Treatment Standards (UTS) for treated solids.

Washing

- Type and quantity of contaminants (organic and inorganic) that are removed with the wash water and that remain with the solid wastes.

- Residence time, operating conditions, and type of surfactants required to remove organic contaminants, and the removal efficiency under various conditions.

- Ability to wash sludges is undefined and untested.

- The level of knowledge of the contaminants required to select surfactants to optimize the washing process is unknown. This refers to the need to characterize the waste in detail to select contaminant-specific surfactants, or whether a surfactant can treat a range of organic species.

- Ability and/or need to meet UTS for treated solids. 
Table 3-24. (continued).

Thermal Treatment

Nonthermal Treatment

\section{Chemical Oxidation}

- The destruction efficiency depends on the contaminant and operational conditions, including residence time in the reactor.

- The potential for producing dioxins in the solution and the nature of the reaction byproducts are unknown until tests are performed on actual wastes under proposed operating conditions.

- These technologies have not progressed beyond the bench scale, so operability, reliability, and maintainability factors are unknown.

- Operational and maintenance requirements and rates of corrosion.

- Types of byproducts, fate of radionuclides and heavy metals.

- Permitting requirements and the need to demonstrate equivalency to BDAT is unknown.

Air Pollution Control Systems ${ }^{a}$

- Ability to continuously monitor emissions to provide feedback and prevent excess emissions during upset or off-normal operating situations.
- Type and quantity of contaminants remaining after the condenser.

- Potential to produce dioxins in the GPCR with various mixtures of chlorinated hydrocarbons.

- Actual destruction efficiency for the various contaminants that may be present.

- Amount of mercury remaining in the offgas and ability to remove trace amounts.

\section{Aqueous Waste Treatment Systems}

Thermal and Nonthermal Treatment

- Details of the type and concentration of contaminants in the wastewater.

- Ability to adequately pretreat the water to sufficient clarity for efficient UV photooxidation treatment. 
- Destruction efficiency of the UV photooxidation process, given the assumed flowrate through the unit.

- The reaction byproducts remaining in the effluent from the UV photooxidation process and whether or not they are hazardous.

- Reliability and maintenance requirements of the UV photooxidation system.

- Whether the effluent from the aqueous waste treatment subsystem meets local discharge requirements.

- Ability to treat chlorinated aromatic organics with UV photooxidation

a. There are few uncertainties because there is considerable experience in designing and operating APC systems that can meet or exceed regulatory requirements. Thermal and nonthermal systems will use similar APCs, though thermal system APCs will be larger.

\subsubsection{Front-End Handling}

Front-end handling involves receiving, waste characterization, and preparation (which includes sorting and size reduction). This is the highest cost subsystem for both thermal and nonthermal systems and, therefore, has the greatest potential for cost reduction. The major cost item is labor, which also introduces the greatest work-related hazard associated with handling and sorting the waste. Although the ITTS and INTS studies assumed robotic and remote handling and sorting, technologies required to perform all these tasks are not yet available. It is particularly difficult to remotely handle the various sizes, types, and conditions of the drums, boxes, and other containers in which DOE waste is stored. There is also the inherent danger of handling corroded and damaged containers of questionable physical integrity that potentially pose a danger to workers and equipment.

Systems such as steam reforming require separation of combustible and noncombustible waste, and nonthermal systems require significant sorting to process different waste matrices with the appropriate treatment method. To realize metal recycle, extraneous metals such as copper and aluminum must be removed from the ferrous metal stream. In the commercial sector, most sorting operations are still performed manually to ensure metal items are removed from the waste stream. Industry has experienced extensive damage to shredders from large metal objects in the waste, and damage to refractory linings of incinerators by metals cause frequent replacement with associated high costs and downtime. Manual sorting has been the only method that reliably removes these potentially damaging items from the waste stream.

The extent of sorting and size reduction of incoming waste needs to be established relative to the size and composition of waste that can safely be fed to the treatment systems. Reliable methods for sorting wastes with minimal personnel must be developed, and/or methods for size reduction must be developed that can process metal objects. Technologies such as metal melting and chemical oxidation also require significant size reduction of metals or combustible debris. However, shredders are generally capable of size reduction to only $1 / 4$-inch, and ball mills have the potential of producing an explosive atmosphere with fine dust particles. Thus, improved, safe size reduction methods must be developed for some technologies that are more efficient when processing small particles of waste. 
Another aspect to front-end handling is characterization. The physical characteristics of the waste that may affect the safety of personnel and treatment operations must be determined or verified, often before opening the drum. Pressurized drums may cause injury to personnel or damage to equipment. Excess organic material injected into a thermal or nonthermal process may lead to an upset or runaway reaction. Materials incompatible with the reagents used in nonthermal processes or with refractory linings in thermal processes must not be fed to reaction vessels. Thermal systems require knowledge of the waste contaminants to validate achievement of the required destruction and removal efficiency; however, similar requirements have not been defined for nonthermal processes. Methods to characterize the waste rapidly, efficiently, and inexpensively need to be developed, or treatment methods and regulations need to be developed that allow less characterization on the front end with improved characterization of the treated waste and effluent with associated process controls to prevent inadvertent release.

\subsubsection{Separation Technologies}

Nonthermal chemical oxidation processes require separation of organic contaminates from noncombustible matrices for treatment. In-matrix destruction of organics in soils, sludges or debris is not recommended because of the large amount of nonhazardous solids that would be dissolved. Dissolution of these additional solids would rapidly deplete the chemical sooner and build up solids in the reagent, requiring more frequent regeneration or replacement and causing unacceptable downtime and higher costs.

Separation technologies that have been considered in the INTS study include thermal desorption and washing. These technologies have some strengths in that they are simple processes that are easy to apply, no hazardous components or reagents are used, and they are applicable to most matrices and organic contaminants. However, the ability to separate organic contaminants from a particular substrate and meet the UTSs depends on the specific application, including type and quantity of contaminants, surface or matrix characteristics, and operating condition such as residence time and temperature. The ability to desorb depends on the contaminant's vapor pressure and the bonds between the contaminant molecules and the particles. The efficacy of washing depends on the solubility of the contaminant, the surfactant used, and the porosity of the particles containing the contaminant. Thus, tests are required to evaluate the ability to remove organic contaminants from all relevant matrices down to the required UTSs.

Although these technologies are applicable to many waste matrices and contaminants, they may not be applicable to all the mixed wastes present in the DOE complex. The capability to either desorb or wash a variety of organic contaminants from inorganic sludges has not been demonstrated. For washing, the applicability of surfactants to various contaminants and matrices must be proven, and the ability to separate contaminants and recover surfactants needs demonstration. Recycling of surfactants depends on whether metals accumulate and remain in the recovered surfactant, and performance data are required on the selected washing process to evaluate metal accumulation and surfactant recovery. There are also many different surfactants and washing processes. Each is more suited to some contaminants than others; thus, extensive characterization may be required to choose the correct surfactant or process.

For low-temperature vacuum thermal desorbers, the fate of mercury, radionuclides, and organic compounds in the desorber system must be determined. Such desorbers should be evaluated for 1) the volume of condensable and noncondensable organic gases leaving the desorber, 2) the effectiveness of desorbing mercury and its compounds, 3) the ability of the offgas systems and condensers to remove volatiles from the offgas, 4) the operating conditions for various feed types, including plastics and other combustible debris, and 5) accumulation of condensed radionuclides and metals on cooler portions of the desorber. 
If nonthermal processes are to be used to treat all wastes, then improved separation technologies must be developed that reliably meet the UTSs for all contaminants and matrices with minimal requirements for front-end characterization.

\subsubsection{Chemical Oxidation Technologies}

Nonthermal destruction of organic materials is performed primarily by chemical oxidation processes such as mediated electrochemical oxidation, acid digestion, or catalyzed wet oxidation. Although these technologies have been under extensive development for several years, there are still many unanswered questions and the overall process requires development and demonstration.

Although dioxins and furans are a major issue with thermal systems, these compounds may also be formed in the aqueous phase under conditions of aggressive chlorination in the presence of aromatic hydrocarbons and under slow aqueous phase destruction of chlorinated aromatic hydrocarbons. Thus, although no dioxins or furans have been reported as reaction byproducts in either the aqueous or gas phases of nonthermal systems, the potential to produce dioxins needs to be evaluated. This is particularly true of the catalyzed wet oxidation process, which uses a concentrated chloride solution for organic destruction.

All chemical oxidation technologies use highly corrosive reagents. Pilot-scale studies are required to evaluate material compatibility and long-term reliability and maintainability. Operating conditions for a variety of waste matrices and contaminants, as well as the destruction effectiveness of the process on mixtures of contaminants, need to be determined. The frequency of inert material removal and reagent replacement, and the fate of RCRA metals and radionuclides need evaluation. The reaction byproducts are unknown and need to be identified; the offgas and aqueous effluent need to be characterized under various operating conditions, including upset conditions when too much organic material is introduced into the process.

Demonstration on a pilot scale is required for processes proposed for recovery and recycling of reagents such as nitric acid in the MEO and acid digestion processes, and hydrochloric acid in the CWO process. Recovery of silver, a RCRA metal, from silver chloride formed in the MEO process when chlorinated hydrocarbons are treated must be demonstrated on a pilot scale. The ability of the acid digestion process to remove $\mathrm{HCl}$ from the nitric acid solution to prevent formation of highly corrosive aqua regia also needs to be demonstrated. In general, all these technologies require a large-scale demonstration of a complete operating system.

\subsubsection{Thermal Destruction Technologies}

All thermal treatment methods require a source of heat, e.g., open flame, plasma torch, induction or resistance heating, or electric arcs. The differences in the generation of particulates, volatile metals, and organics in the offgas may be significant and need to be carefully established to better define the requirements and expected performance of the APC and aqueous waste treatment subsystems. Although considerable data exist, integrated test data are not available for the complex gases from MLLW destruction. The effect of the relationship between APC and aqueous waste treatment system design and the main thermal treatment unit is also unknown.

Volatilization of heavy metals and radionuclides is a major concern for thermal systems. More theoretical and experimental data are needed to identify APC requirements and to identify which systems should be applied to various types of waste. Closely related is the need to remove chloride, and selecting a method for removal, since many of the metals form volatile chlorides. Further, operation under reducing or 
oxidizing conditions influences the formation of volatile metals and metal compounds, products of incomplete reaction or combustion, and formation of dioxins/furans in the effluent from thermal systems.

Although operation under either oxidizing or reducing conditions may be acceptable, the differences need to be known well enough to understand the impacts and requirements of using one or the other. Major issues associated with reducing or oxidizing conditions that require further investigation include the following:

1. Reducing operations may produce as many dioxins or furans as oxidizing processes if precursors are present and if the secondary combustion of the syngas occurs in the presence of $\mathrm{HCl}$ and/or particulates. Methods for removing $\mathrm{HCl}$ and particulates, and the effect on dioxin/furan production, needs to be determined. The optimum sequence of offgas treatment processes needs to be determined for oxidizing and reducing processes to minimize products of incomplete combustion (PIC), dioxins/furans, metals, and radionuclides in the gaseous effluent.

2. Production and management of volatile oxides, chlorides, and metals throughout the systems vary depending on the operating mode and need to be evaluated.

3. Required post-treatment oxidation of gases before release needs to be determined.

4. Methods for managing operating systems to maintain nonexplosive concentrations of gases or pyrophoric metal particles need to be identified and developed.

5. Destruction and removal efficiencies and the fate of RCRA metals, radionuclides, and organics for various thermal system concepts need to be evaluated.

\subsubsection{Air Pollution Control Subsystem}

The design, operation, and efficacy of the APC subsystem depends not only on the design and operation of the primary (thermal or nonthermal) treatment unit, but also on the type of waste and contaminants to be treated, and the control of the feed to the treatment unit. Thus, testing is required for an in-depth understanding of the importance and impacts of feed characterization and control on nonstandard operating conditions or upsets, and the subsequent effect on emissions. Associated with this is determination of the need for over-designed APC systems that can tolerate upsets without increasing emissions.

Performance information is needed to specify the components in the APC that support thermal and nonthermal systems and the optimum sequence of the components. In particular, it is necessary to decide whether dry particulate removal should occur first followed by wet scrubbing to remove chlorides or wet scrubbing first to remove chlorides followed by dry particulate removal. Key issues are: 1) the amount of dioxin/furans that are formed, the cause of their formation, and where they are formed in the system; 2) the capability to remove mercury and the desirable form and disposition of the mercury; and 3) the effectiveness of the backup carbon filters in removing dioxins/furans and mercury. To assess the effectiveness of the APC subsystem, the type and size of particulates and type of gases must be known. Tests need to be coupled with on-line measurements using continuous emission monitors to evaluate performance in normal and abnormal (upset) operating conditions. 
Analytical monitors, whether continuous or intermittent, need to be certified for specific applications. Continuous emission monitors (CEMs) need to be developed, tested, and demonstrated for specific applications. The effect of physical sampling arrangements and locations on performance, and the ability to control or shut down the treatment system if excess contaminants are detected, needs to be evaluated. Reliability of long-term operation of the various monitoring and control devices also needs to be determined. CEMs may not be the answer to gas emission problems; the relationship between CEMs and control of input composition and feed rate of waste to avoid off-normal conditions must be determined. Both are required, along with early feedback controls to adjust operating conditions and prevent contaminant release, but such control linkages are not well developed.

The various technologies that may be used to destroy organic contaminants in the offgas also require investigation. Such technologies include secondary combustion chambers, catalytic oxidation, packed-bed thermal oxidation, and cold plasma devices such as the gas-phase corona reactor. Where these technologies fit in an APC system, their effectiveness under various conditions, and their reliability and cost need to be determined.

\subsubsection{Aqueous Waste Treatment Subsystem}

The sources of liquid waste need to be determined; these may include stored waste, waste from remediation, decontamination, or decommissioning, and aqueous waste generated during the treatment process. Trade-offs between gaseous effluent reduction by condensation of water vapor, which impacts wastewater management, and discharge of water vapor, which affects the APC system, need to be evaluated.

Many technologies for removal of contaminants from wastewaters have been commercialized, and many new technologies are being developed. There are also many advanced oxidation technologies for the destruction of organics in the aqueous phase being developed; however, most are based on production of hydroxyl radicals and have difficulty treating chlorinated aromatics. The options need to be evaluated regarding applicability, effectiveness, and whether there is a need for further research and/or additional development. The need for, and the application of, emerging wastewater treatment technologies needs to be evaluated.

Although much information on the removal of specific radionuclides and toxic materials is known, more information is needed on an assembled subsystem that uses the various treatments sequentially to remove immiscible organics and suspended particulates, dissolved radionuclides and hazardous materials, and residual organics. The efficacy and performance of these technologies needs to be evaluated to identify the optimum system and optimum sequence of unit operations for specific applications. The effectiveness of the sequence of treatment steps and the interactions among the treatment steps need to be known for the appropriate application of the technologies. The back up treatment methods and redundancy factors need to be determined to ensure that the discharged water is cleaned to required standards. As with the APC system, the effect of increased waste input and how variations in the contaminant concentrations in the output should be handled need to be determined.

The effect of the aqueous waste treatment subsystem on the entire waste treatment system needs to be determined. For example, from a performance and life-cycle cost perspective, is a mineral type of ion exchange material (like silico-titanate) that can be stabilized better than an organic resin that can be destroyed in a thermal or nonthermal destruction process? Also, how much secondary waste is generated from regeneration chemicals? 


\subsubsection{Stabilization Subsystem}

Although TLCC numbers indicate the value of vitrified waste forms, the use of high temperature processes is expected to produce enough volatile materials that a separate (secondary) waste stream will be generated that requires a separate low-temperature waste form such as polyethylene. Tests and data on such secondary waste forms are needed to establish their capability to contain radioactive and hazardous materials. The ability to delist these waste forms and the incentives to do so need to be established. The reliable and continual production of quality polymer, ceramic, or grout needs to be demonstrated.

Phosphate-bonded ceramic and grout are relatively porous and sensitive to the waste content and chemistry, so tests are required to establish their long-term ability to contain contaminants and the effect of surface area on release rates.

In nonthermal systems, the removal of organic contaminants from the solid waste matrices is never quite complete and a significant percentage of the incoming organic contaminants could exist in the final waste. This is particularly an issue with semi-volatile and non-volatile organics. The impact of this on the long-term performance of the final waste form and migration into the environment is unknown and needs to be identified.

Classical risk assessments are needed to establish the effectiveness of risk reduction by using polyethylene or other low-temperature forms. The effectiveness of the vitrified, phosphate-bonded ceramic, and polymer waste forms in reducing long-term risk needs to be established against acceptable release rates (which are yet to be established, i.e., how good is good enough?). The effects of surface area (e.g., cracks) needs to be analyzed against behavior during disposal, including release rates. This provides information on whether gem-size glass or highly fractured monoliths are preferable or whether the gems should be encapsulated by using the polyethylene fraction from the secondary waste (polyethylene containing the soluble and volatile metal salts) to gain a better or equivalent long-term performance.

From a systems perspective, waste forms need to be integrated with performance assessments, disposal site location and design, regulations, and R\&D. The characterization and data needed to perform a systems analysis and to make credible and cost effective decisions need to be identified. Are better waste forms needed or are the ones available adequate for all the waste types that need disposal? Are the waste forms sufficiently characterized and the compositions sufficiently identified for the existing waste? Should we simply comply with the existing regulations, or should we do the best job we can considering that longterm stability may be a factor that may cause regulations to change or cause future generations to go back and clean up our disposal sites?

\subsubsection{Summary}

Studying a complete system and evaluating its total life cycle has identified the importance of using the systems approach. Through this thorough analysis, some of the R\&D needs have come to light and relatively unimportant aspects have been recognized. These studies have shown that capital costs are small relative to other factors in the total life-cycle cost of treatment systems, and that emphasis should be placed on improving system performance and reliability. Cost reduction efforts should be focused on operations and maintenance, and research should be focused on reliability and efficiency of operations such as frontend characterization and sorting, and on minimizing waste disposal volume as long as the potential release from the waste form can be kept low. Knowledge of the technical deficiencies provides guidance for R\&D programs. Knowledge of the systems provides the background for combining technologies for effective treatment. 


\subsection{Potential Cost Savings}

In this section potential costs savings are discussed based on the cost analyses and results reported in Tables 3-16 and 3-23.

Approximately $\$ 400$ million can be saved by using a thermal system that uses a vitrifier to produce a glass/ceramic final waste form (Systems A-1, A-2, and H-1) instead of using grout stabilization as in System A-8. An additional $\$ 200$ million could be saved by using a system that produces a slag waste form as part of the thermal destruction process (Systems A-7, C-1 and G-1). Thus, a significant return on investment could be achieved by investing in the development and demonstration of slagging kilns or plasma furnaces for radioactive service.

If the cost of disposal could be decreased by one-half, the savings for thermal systems would be approximately $\$ 130$ million, and the savings for nonthermal systems would be $\$ 350$ to $\$ 400$ million over 20 years. However, if the volume of waste sent to disposal were to decrease by one-half, the same savings in disposal costs could be seen as well as a savings in labor for handling, packaging, and shipping the final waste form. As seen in Table 3-14, on average about 36 FTEs are required in the Certification \& Shipping subsystems for thermal systems, and approximately 100 FTEs for nonthermal systems. If the number of FTEs is based on the volume of final waste form sent to disposal, and the cost is $\$ 140,000 / \mathrm{FTE} /$ year, then decreasing the final waste form volume by one-half would produce a savings in labor costs of $\$ 50$ million for thermal systems and $\$ 140$ million for nonthermal systems. Thus, decreasing the final waste form volume by one-half would produce a total savings of $\$ 180$ million for thermal systems and $\$ 500$ million or more for nonthermal systems. This does not consider the additional costs that may be incurred elsewhere in the system to produce this volume decrease.

If the final waste form volume from nonthermal systems can be reduced to the level of that from thermal systems, then the labor in the nonthermal certification and shipping subsystem could be reduced by approximately $65 \%$. This could be achieved by replacing the grout and most of the polymer operations with vitrification. At the rate of $\$ 140,000 / \mathrm{FTE} /$ year, this would produce a cost savings of approximately $\$ 400$ million in O\&M costs over 20 years in addition to the savings in disposal costs.

One of the major cost factors in both thermal and nonthermal systems is receiving and preparation. If receiving and preparation can be simplified by reduced sorting and characterization by $50 \%$, then a cost savings of $\$ 350$ to $\$ 450$ million could be realized for thermal and nonthermal systems, respectively.

Thus, areas in which return on investment in research and development appear to be highest include improving front-end handling techniques and/or reducing characterization, sorting, and size reduction requirements, and reducing the volume of the final waste forms sent to disposal. However, overall improvements in component and system reliability can produce significant cost savings by increasing system availability from the assumed $4032 \mathrm{hrs} / \mathrm{yr}$ and decreasing maintenance requirements. An increase in operating time to $5850 \mathrm{hrs} / \mathrm{yr}$ can achieve a savings of approximately $\$ 370$ million $^{7}$. 


\section{SUMMARY AND OBSERVATIONS}

The major conclusions that can be drawn from the discussion in the previous sections are listed in Table 4-1. A more detailed summary, organized around the TSWG principles, follows.

Table 4-1. Major conclusions observations.

Thermal Systems

- Thermal systems are simpler.

- A single major thermal treatment process can treat a larger fraction of the waste stream.

- Vitrification of residues maximizes volume reduction and minimizes land used for disposal.

- Thermal systems will be able to meet regulatory requirements (UTS and DRE).

- Incineration-based thermal systems are mature; vitrification of ash requires demonstration but is based on experience.

- Innovative thermal systems have the highest risk operated at pilot scale but no commercial experience on MLLW.

- Thermal systems produce significantly more offgas than nonthermal systems and require high performance APC systems.

- Life-cycle costs of thermal systems are 50 to $60 \%$ less than nonthermal systems.
Nonthermal Systems

- Nonthermal systems consist of immature technologies.

- Destruction efficiencies are not well established for mixtures, or all contaminants or matrices.

- Lack of pilot-scale experience makes performance and cost estimates for nonthermal systems highly uncertain.

- Compliance with current regulatory requirements (UTS and DE) is uncertain.

- Nonthermal stabilization with grout and polymer generates disposal volumes 2 to 3 times the volumes from vitrification.

- Nonthermal systems are complex, with a larger number of subsystems to operate and maintain.

- Nonthermal systems require greater separation and sorting of incoming waste.

- Less recycling of metals is possible.

- Potential for corrosion increases the need for O\&M personnel and may increase the potential for accidents.

- Implementation schedule for nonthermal systems would be 5 to 10 years longer due to immaturity of the technologies.

- Nonthermal offgas volumes are over an order of magnitude less than the offgas from thermal systems.

- Generation of volatile metal compounds in the offgas is not an issue. 


\subsection{Minimize Effluent}

\subsubsection{Minimize Effluent that can Carry Hazardous Materials that Cause Adverse Environmental Consequences}

Solid residues are minimized with systems using vitrification. Nonthermal waste forms have small volume reductions, about one-third the reduction of vitrified waste forms.

Nonthermal systems have low total offgas, about 5 to 20 times less than thermal systems, and volatile RCRA regulated metals, radionuclides, or their compounds have less potential to be entrained in the offgas as particulates. The offgas from thermal systems is composed primarily of non-toxic gases such as nitrogen, a major component of the air used for combustion. Offgas from nonthermal systems is composed primarily of carbon dioxide.

Aqueous effluent from thermal and nonthermal systems varies significantly from system to system, but is less than $2 \mathrm{gpm}$. Most water is recycled and only excess water is discharged. Only two thermal systems consume water at less than $2 \mathrm{gpm}$.

\subsection{Minimize Effects on Human Health and the Environment}

\subsubsection{Minimize Exposure Now}

Both thermal and nonthermal treatment facilities are designed to prevent release of radioactive and hazardous materials to the public and to the workers. Thermal systems have higher gaseous effluent than nonthermal systems, and therefore a greater potential to carry contaminants such as products of incomplete combustion and volatile metals into the discharge. However, the high temperature of thermal systems makes them very efficient in destroying organic contaminants to the required UTS or DRE, and efficient APC systems are available to prevent release above emission standards. Compliance with regulatory requirements for air emissions is achievable for both thermal and nonthermal systems.

The ability of chemical oxidation processes to treat organic contaminants to the UTS is unknown. However, based on vendor data, a combination of chemical oxidation and aqueous destruction has the potential to meet the UTS. Volatile metals, other than mercury, are not an issue, and mercury should be eliminated from the offgas by a series of condensers and the processes designed into the APC system.

The aqueous waste treatment subsystem for thermal systems is larger than for nonthermal systems because of the larger quantity of quench and scrubber water that must be treated. However, the methods for treating the water in thermal and nonthermal systems are essentially the same. These water treatment operations use well known technologies and compliance with regulatory requirements for water emissions is achievable for both thermal and nonthermal systems.

\subsubsection{Minimize Exposure in the Future}

Disposal facilities for thermal and nonthermal waste products are engineered structures with barriers designed to isolate the waste from rain or groundwater to prevent contaminants from leaching into the ground and contacting the groundwater or from running off into lakes or streams. Instrumentation will detect any leakage through the barriers so that repairs can be made to prevent release of contaminants. 


\subsubsection{Minimize Potential for Release of Hazardous Materials from Final Storage/Disposal Products}

Glass/ceramic waste forms are more leach resistant than other waste forms, with lifetimes comparable to natural materials such as basalt, and they are more resistant to future intrusion. However, they are more difficult to fabricate and volatile metals are released that must be captured. Although grouted waste forms are easier to produce and do not volatilize metals, they are less robust, their lifetime is short in a disposal environment, and performance on debris is uncertain. Polyethylene-stabilized waste forms are also easier to fabricate than glass ones, and polyethylene is more chemically inert than grout, but its lifetime in a disposal environment is unknown.

\subsubsection{Minimize Potential for Accidents in the System}

For thermal systems, unplanned injection of a large quantity of high heat content organics could caise a thermal excursion, resulting a sudden pressure increase and release of unburned organic matter and untreated waste to the APC system. This is prevented by monitoring the input to the incinerator. In nonthermal systems, the thermal inertia of the chemical solution would mitigate potential upset conditions, allowing time to cool the reaction and slow the reaction rate. However, because of the acidic nature of the oxidizing solutions, corrosion of the reaction vessels and piping is a major risk, and handling these chemicals is a safety hazard. The catalytic wet oxidation process and acid digestion process operate at elevated pressures (15 to $20 \mathrm{psig}$ ) and pose an additional operational risk.

\subsection{Minimize Waste Generation}

\subsubsection{Minimize Creation of New Hazardous Material by Treatment}

Most of the chemicals used in the nonthermal treatment processes are recovered and recycled. The acid solutions that are not recovered are treated in the aqueous waste treatment system and neutralized to precipitate the salts, which are stabilized for disposal. Thermal systems use only sodium hydroxide to neutralize acid gases in the scrubber solution; the resulting salts are stabilized. Neutralization of these hazardous reagents prevents generation and discharge of new hazardous waste.

\subsubsection{Minimize Final Waste Volume/Amount for Storage/Disposal}

Thermal and nonthermal systems produce essentially the same quantity of special waste, mercury amalgam, and clean lead. System NT-2 produces more mercury amalgam because mercury is removed from debris by thermal desorption. Thermal systems produce more clean iron for recycling because they use metal melters to process steel with internal contamination; such metal cannot be processed and adequately decontaminated by nonthermal methods.

The final waste volumes from thermal systems are less than those from nonthermal systems by about a factor of 3, except for System A-8 which uses grout for stabilization. This is because vitrification requires much less additive than grout or polymer and produces a much denser final waste form. Volume reduction is maximized and better waste forms are produced when combustibles are destroyed by thermal or chemical oxidation as in Systems NT-4 and NT-5. 


\subsection{Address Social, Cultural, and Spiritual Considerations}

\subsubsection{Minimize Land Use for Disposal/Storage}

The majority of the waste sent to stabilization and subsequent disposal is the treated solid waste entering the facility. Waste sent to disposal is minimized by destroying the combustible components by thermal or chemical oxidation; however, this increases the offgas from the treatment process. As discussed in Sections 4.1 and 4.3.2, vitrified waste occupies approximately one-third the volume of grouted or polymer-stabilized waste. The disposal site requires 150 to 210 acres of land for the 1 to 4 million $\mathrm{ft}^{3}$ of stabilized waste (volume depends on the waste form used). Much of this area is buffer zone and access roads, so a $4: 1$ increase in disposal volume increases the disposal site by only $40 \%$. Nonthermal systems require the largest area because of the larger volume of waste produced by nonthermal stabilization processes.

\subsubsection{Waste Should be Disposed in a Retrievable Manner}

Retrievability depends on the final waste form selected and the design of the disposal facility. The concept used in the ITTS and INTS studies was to package the final waste form in steel drums, which are placed in concrete canisters. The canisters are stored in concrete vault cells that, when full, are capped with an earth layer that is engineered to withstand long-term environmental and weathering effects. The ability to retrieve the waste from such a disposal facility was not considered in either the ITTS or INTS studies.

\subsubsection{Stable Waste Forms for Storage and Long Term Disposal}

As discussed in more detail in Section 4.2.3, glass/ceramic waste forms are more leach resistant than other waste forms, with lifetimes comparable to natural materials such as basalt. Grouted and polyethylene waste forms are less robust.

\subsubsection{Reflect Special Site Considerations}

This study assumes a centralized facility at an undefined site. One of the site-specific issues of the TSWG was the amount of traffic associated with such a site. The total truck traffic for hazardous reagents entering the site is 14 truck loads per year of sodium hydroxide for thermal systems, and 25 to 30 truck loads per year of sodium hydroxide and other reagents (including acids) for nonthermal systems. The total truck traffic consists primarily of incoming waste and stabilizing agents for a total of 450 to 500 truck loads per year for nonthermal systems and 350 loads per year for thermal systems. System A-8 requires about 500 truck loads per year because of the greater amount of stabilizing agent required and the greater volume of waste sent to disposal. This amount of truck traffic translates into about 1 to 2 trucks per day entering the facility.

\subsubsection{Reflect Cultural Values}

The cultural values principle addresses sensitive issues that may be site specific or global in nature. The issue that can be quantified by these studies is minimizing land use. As discussed previously, the treatment site requires 50 to 57 acres of which only 5 to $7 \%$ is the actual treatment facility. The remainder is buffer zone, parking, and administration buildings. The disposal site requires 150 to 210 acres of land to dispose of 1 to 4 million $\mathrm{ft}^{3}$ of stabilized waste. Much of this area is buffer zone and access roads. 
Nonthermal systems require a larger disposal area because of the larger volume of waste produced by nonthermal stabilization processes.

\subsection{Adequacy of Information}

\subsubsection{Criteria for Evaluating Systems Should be Flexibly Applied}

Technical criteria were applied qualitatively in selecting thermal and nonthermal systems for analysis. Systems were selected to be representative of effective treatment systems and to provided a range of technologies for evaluation. Final selection was also based on the availability of sufficient cost and performance data to perform a valid analysis.

\subsubsection{Provide Better Information on Health and Safety}

Health and safety issues are being evaluated in a risk analysis for these systems in an ongoing study.

\subsubsection{Provide Better Information on Performance}

As described in more detail in Section 4.2.1, both thermal and nonthermal treatment facilities are designed to prevent release of radioactive and hazardous materials to the public and to the workers. Thermal systems have higher gaseous effluent than nonthermal systems, and therefore a greater potential to discharge contaminants. However, the high temperature of thermal systems makes them very efficient in destroying organic contaminants. Both thermal and nonthermal systems can comply with regulatory requirements for air and water emissions.

\subsubsection{Focus on Existing Stored Waste, Add Projected Impact of Future Waste}

The focus of the ITTS and INTS studies was existing waste. The technologies and systems evaluated in these studies are also applicable to wastes that will be generated in the future. A study is in progress on the system modifications required to treat remediation waste that consists primarily of soil with some debris.

\subsubsection{Communicate When Systems of Technologies Could be Implemented}

The implementation schedule for these systems depends on their level of development and maturity. Rotary kilns are the most mature system and could be implemented in 2 to 3 years if permits could be obtained. The more innovative thermal systems and the nonthermal systems require significant research and development and demonstration, with implementation estimated at 7 to 10 years.

\subsection{Cost}

Cost was not a TSWG principle. However, it is an important factor in evaluating systems and determining where research and development dollars might be spent to decrease the cost of treating DOE wastes without sacrificing performance with respect to worker safety and public exposure to contaminants.

The major subsystem cost is receiving and preparation, which is about 25 to $30 \%$ of the total lifecycle cost for both thermal and nonthermal systems. This includes receiving, characterization, sorting, and size reduction. This is followed by costs for stabilization for thermal systems using vitrification. For 
nonthermal systems, disposal costs and certification and shipping costs are nearly the same as receiving and preparation costs; nonthermal system costs exceed thermal system costs for these three subsystems.

The major cost element is $0 \& \mathrm{M}$, which is 50 to $60 \%$ of the total life-cycle cost for both thermal and nonthermal systems, followed by capital costs for systems using a vitrifier, and then by disposal costs. Capital costs (equipment and construction) range from 15 to $24 \%$ of the total, so process selection should be based on performance, reliability, and technical risk rather than technology cost. Disposal costs are about $20 \%$ of the total cost for nonthermal systems, and $11 \%$ for vitrification.

Life-cycle costs for thermal and nonthermal systems range from $\$ 2$ to $\$ 4$ billion, with costs for nonthermal systems greater than for thermal systems by about 40 to $60 \%$ (including disposal). Average nonthermal O\&M costs are $60 \%$ higher than the thermal system costs; however, performance uncertainty could increase these costs further. Labor costs are the major driver, with energy costs making up a small fraction $(<1 \%)$ of the total life-cycle costs.

The nonthermal systems used in the INTS studies are significantly more costly than thermal systems for several reasons. Because of the need for a more complex system, it is doubtful that nonthermal systems can be economically competitive with thermal systems. If the waste residue is vitrified instead of using nonthermal stabilization technologies, approximately a $\$ 500$ million reduction in disposal costs may be realized; however, large cost differences would remain between thermal and nonthermal systems for the above reasons. 


\section{REFERENCES}

1. F. Feizollahi and W. J. Quapp, Integrated Thermal Treatment System Study - Phase 1 Results, EGG-MS-11211, Idaho National Engineering Laboratory, Idaho Falls, Idaho, July 1994.

2. F. Feizollahi and W. J. Quapp, Integrated Thermal Treatment System Study - Phase 2 Results, INEL-95/0129, Revision 1, Idaho National Engineering Laboratory, Idaho Falls, Idaho, February 1996.

3. C. Biagi, et al., Integrated Thermal Treatment System Study - Phase 2 Results, Addendum, System A-8, Draft, Idaho National Engineering Laboratory, Idaho Falls, Idaho, May 1996.

4. C. Biagi, et al., Integrated Nonthermal Treatment System Study, Draft INEL-96/0273, Idaho National Engineering Laboratory, Idaho Falls, Idaho, January 1997.

5. Independent Peer Review Panel Report on the Integrated Nonthermal Treatment Systems Study and the Comparison of Integrated Thermal and Integrated Nonthermal Treatment Systems for Mixed Low Level Waste, Office of Science and Technology, U. S. Department of Energy, Washington, D. C., August 1996, DOE/EM-0320.

6. C. Biagi and J. Vetromile, Time and Motion Study for Alternative Mixed Low Level Waste Treatment Systems, Draft, INEL-97/0017, Idaho National Engineering Laboratory, Idaho Falls, Idaho, February 1997.

7. L. A. Harvego and J. J. Schafer, Integrated Thermal and Nonthermal Treatment Technology and Subsystem Cost Sensitivity Analysis, INEL-96/0291, Idaho National Engineering Laboratory, Idaho Falls, Idaho, September 1996.

8. J. Paladino and P. Longsworth, Maximizing R\&D Investments in the Department of Energy's Environmental Clean-Up Program, Office of Technology Development, U. S. Department of Energy, Washington, D. C., distributed in 1995 


\section{APPENDIX A}

Glossary of Terms 


\section{Glossary of Technical Terms}

Absorption

Acceptability

Acid digestion

Acid gas scrubbing

Activated carbon

Additives

Adsorption

Advisory Groups

Aggressive chemical treatment

Agitation wash

Air pollution control (APC)

Airborne releases

Alpha particle

Alpha waste
The dissolving of one compound, usually a gas, in another, usually a liquid.

Satisfactory performance to achieve overall goals; feasibility in the real world.

The use of strong acids such as nitric acid and phosphoric acid to dissolve organic and inorganic compounds in an acid medium.

The removal of by-product gases such as sulfur dioxide $\left(\mathrm{SO}_{2}\right)$ or hydrogen chloride $(\mathrm{HCl})$ by bringing the gases into contact with water or a mildly alkaline solution.

Fine granular carbon specifically formulated to adsorb organic compounds.

Chemicals added to waste as part of treatment. Examples are sodium hydroxide added to neutralize wastewater or surfactants (detergents) added to water to wash soil.

The physical attachment of one chemical compound to another, such as benzene to carbon.

Individuals selected to provide input to and review of the development of a project.

A process using strongly acid or strongly basic chemicals to quickly attack other materials, including organics and metals.

A washing system which uses the same principles as the common household washing machine.

Equipment designed to treat air, vapors and gases exiting a process before releasing the gas stream to the atmosphere.

The volume of gas (including air, carbon dioxide, and contaminants) released to the atmosphere from a treatment facility.

A positively charged particle consisting of two protons and two neutrons that is emitted from the nucleus of certain nuclides during radioactive decay. It is the least penetrating of the four common types of radiation (alpha, beta, gamma and neutron).

Waste contaminated with alpha radioactivity measuring 10 to 100 nanoCuries per gram of waste.

A-1 
Amalgam

Amalgamation

Ambient

Analysis

Anolyte

Applicability

Application

Aqueous waste

Aqueous wash

ASPEN PLUS (ASPEN)

Assess

Assumptions

Atmospheric pressure

Atomic Energy Commission (AEC)

Availability

Bench scale testing
An alloy of mercury with another metal that is solid or liquid at room temperature according to the amount of mercury present.

A process of stabilizing a mixture of diverse elements together; as described in this report, mercury and other metals are stabilized as an amalgam.

Environmental/weather conditions that exist at a given location, including, temperature, pressure, rainfall, etc.

Chemical analysis: the identification of ingredients of a substance by performance of laboratory tests. Engineering analysis: an examination of a process or problem, its elements and their relationships.

Liquid solution containing positively charged ions produced in contact with electrodes, used for destruction of organic compounds.

Capable of being put into practice.

An act of putting to use new techniques.

Wastes that are combined with water and have an organic content of $1 \%$ or less.

A washing technique which uses water in a combination with various surfactants.

A computer program which applies chemical engineering principles to generate information relating material flowing into a system to material flowing out of the system.

To determine the importance, size or value of; to evaluate.

A fact or statement taken for granted.

Normal barometric pressure.

A five-member commission established after World War II to supervise the use of nuclear energy. The AEC was dissolved in 1975 and its functions transferred to the Nuclear Regulatory Commission (NRC) and the Energy Research and Development Administration (ERDA). The latter became the Department of Energy (DOE).

This criterion identifies the amount of time the technology or system is available for operation and treatment of waste.

Chemical or physical testing that occurs as a first step in a laboratory. This test equipment is usually very small in scale (the size of household blenders and 2 or 4 cup measures). Bench scale testing is an initial 


\section{Beta particle}

Biota

Blowdown

Bulk soil

Byproducts and residuals

Canister

Canyon

Capping

Catalytic wet oxidation (CWO)

Catholyte

Centigrade (Celsius)

Characterization evaluation to determine if a process is a good idea (Does it work well? Would anybody be interested in it?).

An elementary particle emitted from a nucleus during radioactive decay. It is negatively charged, is identical to an electron, and is easily stopped by a thin sheet of metal.

The plant and animal life of a region.

The withdrawal of water from an evaporating process to maintain a solid balance within specified limits of concentrations of those solids.

Bulk quantities of soil removed from the ground for treatment.

During treatment, components of wastes are separated to isolate hazardous compounds and remove them from the waste. These separation processes may generate byproducts. As an example, the neutralization of acids generates soluble or insoluble salts:

$\mathrm{HCl}+\mathrm{NaOH}=\mathrm{NaCl}+\mathrm{H}_{2} \mathrm{O}$

(Hydrochloric acid + sodium hydroxide $=$ table salt + water)

Residuals are the leftovers, such as the solids remaining at the bottom of the evaporator.

A stainless-steel container in which immobilized radioactive waste is sealed.

A heavily shielded building used in the chemical processing of radioactive materials to recover special isotopes for national defense or other programmatic purposes. Operation and maintenance are by remote control.

The process of sealing or covering a waste unit with a low permeability medium.

A chemical process which utilizes a strong acid medium in the presence of a catalyst to convert organic compounds to carbon dioxide, water and acid gases.

Liquid solution containing negatively charged ions produced in contact with electrodes in conjunction with the positively charged anolyte.

A temperature scale that registers the freezing point of water as $0^{\circ} \mathrm{C}$ and the boiling point as $100^{\circ} \mathrm{C}$ under normal atmospheric pressure.

The description of the chemical nature of waste. Laboratory analysis is performed on waste to determine generically what it is and whether it has chemical such as hazardous organics that must be treated.

Characterization may be necessary for waste as it enters the facility to 
Chemical oxidation

Chemical Composition

Complex Debris

Complexity

Concentration

Condensate

Confidence level

Constituents

Contaminant

Contaminant loading

Criteria pollutant

Curie (Ci)

Decay, radioactive

Decommissioning determine the nature of treatment required. Also characterization may be needed before shipment, to determine that the hazardous substances in the final waste form are below regulatory limits.

The reaction of a compound with oxygen or an oxygen donor to convert the compound to an oxidized state.

A list of the chemicals in a sample, and the percentages of each chemical or element.

Debris that has crevices or hard to access areas, such as pipe, valves, pumps, complex machinery, etc.

The state of intricacy, complication, multiple parts and processes and the interrelatedness of these parts. Mechanical, chemical, and operational complexity as well as the number of processes required are considered part of this aspect.

The quantity of a substance contained in a unit quantity of a medium (e.g., micrograms of aluminum per liter of water).

Liquid water obtained by cooling the steam produced in an evaporator system.

The certainty of a particular point (measurement, amount, value) being within a statistically determined range.

Parts or components of a chemical system.

Hazardous or radioactive constituents, as defined by EPA and other regulatory agencies.

The concentration of contaminants in the waste.

Air pollutants for which the EPA has established concentrations below which the pollutants do not pose a threat to public health and welfare.

A unit of measure of radioactivity equal to $37,000,000,000$ decays per second. A curie is also a quantity of any nuclide or mixture of nuclides having one curie of radioactivity.

The spontaneous transformation of one nuclide into a different nuclide or into a different energy state of the same nuclide. The process results in the emission of nuclear radiation (alpha, beta, gamma, or neutron radiation).

The removal from service of facilities such as processing plants, waste tanks, and shallow land disposal units, and the reduction or stabilization of radioactive contamination. Decommissioning concepts include: 


\section{Decontamination}

Decontamination and
decommissioning (D\&D)

Desorption

Dioxin

DOE

DOE Complex

Ecological effects

Ecology

Effectiveness

Effluent

Engineered trench

Engineering judgement
- Decontaminate, dismantle, and return area to original condition without restrictions.

- Partially decontaminate, isolate remaining residues, and continue surveillance and restrictions.

The act of removing a chemical, biological, or radiological contaminant from, or neutralizing its potential effect on, a person, object, or environment by washing, chemical action, mechanical cleaning, or other techniques.

This criterion assesses $D \& D$ requirements including hazards, expected effectiveness, residual contamination levels, and the potential for turning over the facility for alternative uses. All five nonthermal systems will require approximately the same amount of $D \& D$. At this stage of design this criterion cannot discriminate between systems. Specific requirements and results of D\&D efforts have not been determined.

The process whereby a liquid leaves a solid by diffusing into a gas phase.

Highly toxic chlorinated organic compound present in Agent Orange. Probably a carcinogen.

\section{U.S. Department of Energy.}

The $50+$ sites owned by the DOE.

Damage or benefits to soil or groundwater as a result of the construction, operation, or D\&D of the treatment facility.

The study of the relationships between living things and their environments.

How well the technology or a system performs its required function. Effectiveness answers the question "How well does this work?"

Any material which leaves a system.

Reinforced, concrete-formed, walled disposal trench with steel covers over each area to minimize rainwater intrusion and direct drainage away from the trench. A leachate collection system installed below the floor of the trench monitors the performance of the disposal cells.

Qualitative judgment based on experience and familiarity with the subject. 
Environmental restoration

Evaporation

Evaporator bottoms

Exothermic

Exposure to radiation

Filtration

Final waste form volume

Flexibility

Flow rates

Full-time equivalent worker (FTE)

Gamma rays

Gas phase corona reactor (GPCR)

\section{Groundwater}

Grout
Required activity to return soil, groundwater and vegetation to conditions before facility operation.

The conversion of a volatile compound to a gaseous phase, such as the boiling of water.

The sludge that remains in the bottom of an evaporation apparatus after the desired product has evaporated and been removed.

A chemical change accompanied by a release of heat.

The incidence of radiation on living or inanimate material by accident or intent. Background exposure is the exposure to natural background ionizing radiation. Occupational exposure is the exposure to ionizing radiation that occurs during a person's working hours. Population exposure is the exposure of a number of persons who inhabit an area.

The separation of solids from a liquid or gas by passing the liquid or gas through a porous media which will pass the liquid or gas and retain the solids.

The ability of the disposed waste to remain stable or to release contaminants such as radionuclides. Waste form performance is estimated by performing leaching tests (see TCLP).

The volume of stabilized waste shipped out of a treatment facility.

Ability of a system or process to tolerate a range of waste compositions

The amount of material per hour that passes through a process; e.g. a typical shower has a water flow rate of 1 to 7 gallons per minute.

For cost estimates, $40 \mathrm{hrs} / \mathrm{wk}$ of labor. Since labor may be used flexibly, FTEs are calculated rather than assigning a head count.

High-energy short-wavelength electromagnetic radiation accompanying fission, radioactive decay, or nuclear reactions. Gamma rays are very penetrating and require relatively thick metal/lead shields to absorb the rays effectively.

A device which uses electricity to break down organic compounds in a gas stream.

The supply of fresh water in an aquifer under the Earth's surface.

A material composed of ingredients such as cement, sand, ash and water. 
Grout stabilization

Hazardous materials

Hazardous operating conditions

The use of combination of cement, sand, ash and water with waste to form solid concrete-like mass which is resistant to leaching.

Chemicals defined by EPA as hazardous based on toxicity, reactivity, flammability or other characteristics.

Conditions in the workplace which may pose a hazard to operations personnel. Typical hazardous conditions include moving machinery, temperatures and pressures above ambient, and chemicals and radionuclides which can cause illness.

Hazardous process equipment Equipment which under normal operation presents hazards to workers. Examples of hazardous process equipment are reactors under pressure, electrical transformers, and metal melting equipment.

Hazardous reagents

Hazardous waste generation

Hazardous waste storage facility

Heavy metals

HEPA filter

High pressure wash

Hydrolysis

Hydroxyl radicals

Immiscible organics

Immobilization

Implementability

Incineration
A hazardous substance used in chemical reactions.

Creation of new hazardous waste during the treatment of existing DOE waste.

Resource Conservation and Recovery Act (RCRA) permitted temporary holding area for hazardous waste prior to treatment or disposal.

Metallic elements of high atomic mass such as mercury, chromium, cadmium, lead, or arsenic, that are toxic at known concentrations to plants and animals.

High-Efficiency Particulate Air filter designed to remove from a flowing air stream $99.95 \%$ of the particles as small as 0.3 micrometer.

A process which uses a liquid spray, usually water, at high pressure to remove surface adhered particles.

A process of decomposition in which a compound is broken down and changed into other compounds by taking up the elements of water.

A negatively charged ion which consists of one oxygen atom and one hydrogen atom.

Organic compounds that are not soluble in another liquid, such as oil which would float on the top of water.

Conversion of a material into a form that will resist environmental dispersion.

Potential to actually be put into service; a combination of practicality and acceptability.

The burning of waste. 
INEL

Influent

Inorganic

Input

INTS

Ion

Ion exchange

ITTS

Kilo

Leach resistant waste form

Leaching

Macroencapsulate

Magnesium phosphate

Maintainability

Maintenance worker exposure Exposure of maintenance workers to hazardous or radioactive waste.

Mass Workers repair equipment which may have been in contact with radioactive and/or hazardous waste.

Idaho National Engineering Laboratory near Idaho Falls, which is one site in the DOE complex.

Any material that flows into a system.

Any chemical compound which does not contain carbon in its structure.

Something that is put in, such as labor, raw material, waste, additives. In this report, input often refers to a waste or additives put into a process.

Integrated Nonthermal Treatment Systems- a series of conceptual designs using nonthermal processes to treat and stabilize radioactive mixed waste.

An atom or molecule that has gained or lost one or more electrons and has become electrically charged.

Process in which a solution containing soluble ions to be removed is passed through a column of material that removes the soluble ions by exchanging them with ions from the material in the column. The process is usually reversible so that the trapped ions can be collected (eluted) and the column regenerated.

Integrated Thermal Treatment Systems- a series of conceptual designs using thermal processes to treat and stabilize radioactive mixed waste.

A prefix meaning one thousand $\left(10^{3}\right)$ of any measurement

A waste form that is stable enough to resist outside materials from removing any trapped components from its structure.

The removal of compounds by the percolation of liquids; e.g. drip coffee is a leaching into water of compounds in ground coffee beans.

To seal (e.g., in a box or polymer) a contaminated component so that the contamination is contained.

A nontoxic inorganic compound.

The ability of equipment, technologies or systems to be kept in working condition.

A measure of the amount of material in a given body; most commonly in this report, the weight of the body. 
Material mass balances

Material

Matrix

Mediated electrochemical

oxidation (MEO)

Mercury Waste

Micro

Milli

Nano

NEPA

Nitric acid

Non-alpha waste

Nonthermal

Nonthermal systems

NOx

NRC

Nuclear radiation
An analysis showing the mass movement of materials or constituents through a process. For example, a mass balance of cooking vegetables in hot water would list the weight of water and vegetables added to the pot, the mass of water vaporized, the water remaining in the pot following cooking and the final weight of the cooked vegetables. The total weight of cold water and uncooked vegetables in the pot must equal (balance) the weight of the water lost in evaporation, the water remaining in the pot, and the weight of the cooked vegetables.

Matter that has individual qualities that define it (hazardous material, waste material).

A material in which something is enclosed or embedded; eg, radionuclides in soil, solvents in wastewater.

MEO is an aqueous process which uses electric energy to react with organics and break them down to carbon dioxide and water.

Waste material such as debris which contains concentrations of mercury above regulatory limits.

A prefix meaning one millionth $\left(10^{-6}\right)$ of any measurement.

A prefix meaning one thousandth $\left(10^{-3}\right)$ of any measurement.

A prefix meaning one billionth $\left(10^{-9}\right)$ of any measurement.

National Environment Policy Act of 1969; it requires the preparation of an Environmental Impact Statement (EIS) for Federal projects that could significantly impact the environment.

A common acid composed of nitrogen, hydrogen and oxygen $\left(\mathrm{HNO}_{3}\right)$.

Waste contaminated with alpha radioactivity measuring less than 10 nanoCuries per gram of waste.

Processes with maximum temperatures below $660^{\circ} \mathrm{F}\left(350^{\circ} \mathrm{C}\right)$.

Systems composed of physical and chemical processes which occur at temperatures below $350^{\circ} \mathrm{C}\left(660^{\circ} \mathrm{F}\right)$.

Oxides of nitrogen (NO, $\mathrm{NO}_{2}, \mathrm{NO}_{3}$ ) which form at high temperatures (as in a car engine) or as breakdown products of nitric acid.

Nuclear Regulatory Commission; the independent Federal commission that licenses and regulates commercial nuclear facilities.

Radiation, usually alpha, beta, gamma, or neutron, which emanates from an unstable atomic nucleus. 
Offgas

Off-normal conditions

Open Debris

Organic

Output

Oxidation

Parameter

Particulates

Peer review

pH

Phosphate bonded ceramic

Photo-oxidation

Pilot scale systems

Pollution

Polymer
Vapors and gases (including air) which are given off from a process; cooking odors are a form of offgas.

Conditions outside of normal processing range, for example: elevated temperature or pressure, $\mathrm{pH}$ too high (basic) or too low (acid), excessive electricity usage, jammed equipment.

A classification of debris which includes concrete, bricks, drums, glass, metals.

Chemical compounds which contain carbon and hydrogen; these chemicals are associated with living entities.

Something that is produced; a yield. Typically in this report we describe as output the materials resulting at the end of a process, e.g. treated stabilized waste, evaporated water, etc.

In this report, the reaction of a compound with oxygen, either directly or indirectly.

A characteristic element; any of a set of physical properties whose values determine the characteristics or behavior of something, e.g. volume, temperature, etc.

Solid particles small enough to become airborne.

Scientific review of documents by qualified outsiders.

A measure of the hydrogen ion concentration in aqueous solution. Pure water has a $\mathrm{pH}$ of 7 , acidic solutions have a $\mathrm{pH}$ of less than 7 , and basic solutions have a $\mathrm{pH}$ greater than 7 .

A form of cement which uses phosphates rather than the more common calcium based ingredients used in concrete.

A process that uses light to cause a reaction of organic chemicals in water yielding harmless substances (carbon dioxide and water).

Chemical process equipment at a small scale (fits in a large laboratory) designed to test the practical aspects of a new process. These systems often process volumes of 20 to 50 gallons.

The addition of any undesirable agent to an ecosystem in excess of the rate at which natural processes can degrade, assimilate, or disperse it.

Long chain chemicals with repeating chemical units; for example, nylon and plastics. 
Polymer stabilization

Precipitate

Preconceptual design

Precursors

Process flow diagrams (PFD)

Process controls

Process containment

Promulgated

Public acceptability

Qualitative

Quantitative

Radioactive materials

Radioactive waste
Mixing of waste residues together with melted plastics which cool to form a stable solid.

A solid (used as a noun).

To form a solid substance in a solution by a chemical reaction (used as a verb).

Engineering design analysis performed to develop basic concepts. This design evaluates the feasibility of a project. Specific details, such as exact location, supporting equipment and instrumentation, are not included.

Chemicals that are the building material for the formation of other chemicals.

Box diagrams with arrows indicating material flow through a process. In this report, the PFDs show the type of waste treated, the treatment process used, and the products of the process.

Instrumentation which is provided to control and operate equipment. Sensors receive electrical and air pressure signals. The signals are processed by the instrumentation. For example, a device is installed in a water-jacketed reactor to monitor the temperature. If the temperature gets above an instrument set point, flow of cooling water through the jacket is increased until the temperature in the reactor is in the proper range.

Engineered safety features such as instrumentation that shuts down malfunctioning equipment, concrete barriers that collect spilled liquid, and warning devices that notify staff of off-normal conditions.

A law put into action or force.

Concepts (or designs, facilities) found to be satisfactory or adequate by the general public.

Related to or involving the general qualities and characteristics; not involving numerical analysis.

Related to or involving the measurement of amounts, quantities, and parameters such as temperature, pressure, $\mathrm{pH}$, chemical concentration.

Materials which contain artificially produced radioactive metals which spontaneously emit radiation (atomic particles).

Materials from nuclear operation that are radioactive or are contaminated with radioactive materials for which there is no practical use or for which recovery is impractical. 
Radiolysis

Radionuclides

RCRA metals

Reagents

Recycled metals

Reliability

Research and development (R\&D)

Residues

Resource utilization

Salts

Schedule

Scrubber

Silver chloride
The decomposition of a material (usually water) into different molecules due to ionizing radiation. In water, radiolysis results in the production of hydrogen gas and oxygen.

Elements which emit radiation.

Metals whose handling and disposal are regulated by the EPA. RCRA requires that metals disposed of pass a TCLP test demonstrating that they will remain in the stabilized waste and will not migrate at any appreciable rate.

Pure form of chemicals used in the laboratory.

Metals from which radionuclides or hazardous compounds have been removed that can be reused within the DOE complex

Dependability; the expected stability of system operations.

Work performed in laboratories and research facilities. Research looks at which processes are the most promising and considers whether a process is effective. Development takes the best processes from research, evaluates the key parameters, and tests the process pilot scale equipment.

Remainder of waste left after treatment, often sludges and dried solids (e.g., coffee grounds).

In a proposed design or project, the requirements for resources to support the project. These include energy (electrical or thermal in the form of hydrocarbons), chemical reagents, and personnel.

Any of numerous compounds that result from the replacement of part or all of the acid hydrogen of an acid by a metal or a group acting like a metal; an ionic crystalline compound. For example, when hydrochloric acid is mixed with sodium hydroxide (caustic) the result is table salt and water:

$\mathrm{HCl}+\mathrm{NaOH} \Rightarrow \mathrm{NaCl}+\mathrm{H}_{2} \mathrm{O}$.

A planned sequence of operations. Key schedule aspects for technologies include required research, development, demonstrations, engineering design, permitting, construction and installation and startup.

Engineered equipment used to remove constituents from a gas stream by absorption and/or chemical reaction.

A common chemical used in photography. 
Simplicity

Site expanse

Sizing

Sludge

Soft Debris

Solvent

Special Waste

Stabilization

Storage

Surfactants

Suspended solids

TCLP tests

Technology development status

\section{Thermal desorption}

Thermal system

Total life cycle cost
Easy to operate, not complicated.

The fenced area required to accommodate operating facilities.

Reduction of size by cutting, shredding, grinding or other methods.

The precipitated solids (primarily oxides and hydroxides) that settle to the bottom of the storage tanks containing liquid high-level waste.

A category of debris which includes cardboard, plastic, wood.

A substance, usually liquid, that can dissolve other substances.

Waste requiring unusual treatment.

Process designed to limit the mobility of chemicals and prevent toxic chemicals from escaping into the environment.

Retention of radioactive waste in man-made containers, such as tanks or vaults, in a manner permitting retrieval (as opposed to disposal, which implies no retrieval).

Chemicals used to bring together oily and water-based solutions; soaps and detergents are examples.

Tiny solid particles that remain in a liquid; for example, mud which stays suspended in flowing water.

Toxicity Characteristic Leaching Procedure - a chemical test required by the EPA for certain wastes at the time of disposal; the test imitates nature's ability to react with metals in the ground and demonstrates how much metal could be leached out of the waste over time. The EPA requires the tested wastes disposed of to be below a legal limit as described in 40 CFR 268.

The current level of development of the technologies, i.e., laboratory or bench scale (about 1 quart process or less), pilot scale (about a 5 gallon to $\mathbf{5 0}$ gallon process), production or full scale (size required, usually over 200 gallons), commercial (available and proven), etc.

A process which uses heat to convert volatile liquids into a gas phase thus allowing them to be removed from solids.

System that employs enough heat that raises the temperature above $350^{\circ} \mathrm{C}\left(660^{\circ} \mathrm{F}\right)$.

Total life cycle cost includes the cost of all facets of treatment and disposal of the waste, from research of treatment processes through disposal of the last of the waste. Facets include $R \& D$, pre-operational 
Toxic

TRUPACT II activities, installation of production facilities and equipment, O\&M activities, D\&D, and disposal. TLCC costs which do not include disposal are described as "TLCC without disposal".

Chemicals known to cause harm to humans or animals through exposure routes such as ingestion (eating), inhalation (breathing), dermal contact (through the skin).

Trademark name for a DOE approved transportation container for contact-handled transuranic waste. The container is capable of holding 14 55-gallon drums.

Upset and accident conditions Processing conditions outside the normal range and/or mechanical failures. Examples include overflowing tanks, runaway reactions, unexpected sudden loss of pressure.

Vacuum thermal desorption

A process similar to thermal desorption but additionally employs the use of vacuum to enhance the transport of volatile liquids into the gas phase for removal.

Capable of varied uses or functions; as an evaluation criterion, considers the fraction of the waste inventory that can be treated by the technology or system.

The conversion of materials through the use of high temperature and additives to a glass-like form.

Volatile organic compounds

Volatilized

Volume reduction

Waste acceptance criteria

Waste certification criteria

Waste Isolation Pilot Plant

Wastewater
An organic compound with a vapor pressure greater than 0.44 pounds per square inch at standard temperature and pressure.

Evaporated; passed off as a vapor.

The relationship of the volumes of output waste to input waste. If less waste volume is left after treatment and stabilization than the volume of waste that entered, then waste is reduced.

Criteria established by a waste management facility which define the waste it will accept.

Criteria that must be met for transport, treatment, and disposal of waste.

DOE facility located near Carlsbad, New Mexico, built to demonstrate the safe underground disposal of transuranic waste from numerous facilities owned by DOE.

Water, usually used in some process, that contains organic or inorganic contaminants that are considered to be undesirable. 
Wastewater releases

${ }^{\circ} \mathrm{C}$

${ }^{\circ} \mathrm{F}$

${ }^{\circ} \mathrm{K}$
The volume of treated wastewater (including contaminants) discharged from the treatment facility.

Degree Centigrade (Celsius). ${ }^{\circ} \mathrm{C}=5 / 9 \times\left({ }^{\circ} \mathrm{F}-32\right)$.

Degree Fahrenheit. ${ }^{\circ} \mathrm{F}={ }^{\circ} \mathrm{C} \times 9 / 5+32$.

Degree Kelvin. ${ }^{\circ} \mathrm{K}={ }^{\circ} \mathrm{C}+273$. 